UNIVERSIDADE DE SÃO PAULO

FACULDADE DE ECONOMIA, ADMINISTRAÇÃO E

CONTABILIDADE

DEPARTAMENTO DE ADMINISTRAÇÃO

PROGRAMA DE PÓS-GRADUAÇÃO EM ADMINISTRAÇÃo

FATORES ASSOCIADOS AO COMPROMETIMENTO DE FUNCIONÁRIOS DE EMPRESAS DE TELECOMUNICAÇÕES

Rosalina Semedo de Andrade Tavares

Orientadora: Profa. Dra. Ana Cristina Limongi-França

São Paulo

2010 
Prof. Dr. João Grandino Rodas

Reitor da Universidade de São Paulo

Prof. Dr. Carlos Roberto Azzoni

Diretor da Faculdade de Economia, Administração e Contabilidade

Prof. Dr.Adalberto Américo Fischmann

Chefe do Departamento de Administração

Prof. Dr. Lindolfo Galvão de Albuquerque

Coordenador do Programa de Pós-Graduação em Administração 
ROSALINA SEMEDO DE ANDRADE TAVARES

\title{
FATORES ASSOCIADOS AO COMPROMETIMENTO DE FUNCIONÁRIOS DE EMPRESAS DE TELECOMUNICAÇÕES
}

\begin{abstract}
Tese apresentada ao Departamento de Administração da Faculdade de Economia, Administração e Contabilidade da Universidade de São Paulo como requisito para a obtenção do título de Doutor em Administração.
\end{abstract}

Orientadora: Profa. Dra. Ana Cristina Limongi-França

São Paulo

2010 
FICHA CATALOGRÁFICA

Elaborada pela Seção de Processamento Técnico do SBD/FEA/USP

Tavares, Rosalina Semedo de Andrade

Fatores associados ao comprometimento de funcionários de empresas de telecomunicações / Rosalina Semedo de Andrade Tavares. - São Paulo, 2010.

$215 \mathrm{p}$.

Tese (Doutorado) - Universidade de São Paulo, 2010.

Orientador : Ana Cristina Limongi França

1. Administração de recursos humanos 2. Comunicação organizacional 3. Comunicação interna 4. Comprometimento organizacional I. Universidade de São Paulo. Faculdade de Economia, Administração e Contabilidade II. Título.

CDD - 658.3 
A Deus, pelas oportunidades que tem me oferecido.

Ao Lucas, filho adorável que me iluminou de ternura com a sua chegada. Às minhas mães, pelo exemplo admirável de vida. Ao meu marido, Carlos, pelo amor, apoio e companheirismo. Aos meus irmãos, pela amizade, carinho e incentivo de sempre. 


\section{AGRADECIMENTOS}

Concluir esta tese não foi trabalho fácil. Durante todo o percurso tive a sorte e a grata satisfação de receber estímulo e ajuda de pessoas que muito contribuíram para a concretização deste objetivo. Em primeiro lugar, muito mais do que agradecer, dedico este trabalho ao meu filho Lucas, um novo motivo para sorrir, uma nova razão para ser feliz e um motivo ainda maior para continuar a lutar; a minha mãe Eduina pelo apoio, confiança e estrutura de valores que me proporcionou, ao meu pai pelos incentivos, ao meu marido, pela compreensão e apoio, aos meus irmãos, pelos momentos de carinho, de apoio e por toda a estrutura e união familiar; aos meus familiares por sempre compreenderem minha presença "ausente" e por se fazerem presentes em todos os momentos. Também quero deixar registrado meu agradecimento a todas aquelas pessoas que participaram direta ou indiretamente deste trabalho, em especial:

- A professora Ana Cristina Limongi-França, a qual conduziu o processo de orientação de forma tranqüila e serena, atuando sempre em parceria.

- Os professores Maria Aparecida Gouvêa e Lindolfo Galvão de Albuquerque pelas ricas contribuições.

- Andréa Kanikadan, amiga de todos os momentos. Agradeço o seu mais puro sentimento de amizade.

- Mafalda Mussengue, amiga com a qual pude compartilhar momentos de angústias e alegrias na consecução deste trabalho. Obrigada pela amizade e carinho.

- Os amigos Paula Kanikadan, Ângela Abduch, Dulce Fernandes, Augusta Évora, Tâmara Águas, Ailton Almeida, Amarina Monteiro; Odete Andrade, Elsa Vaz, Ruth Neves. Obrigada pela amizade e por todo o apoio.

- O amigo Jorge Garcia por todo o apoio, principalmente no momento da realização dos contatos com a empresa pesquisada em Cabo Verde.

- Os amigos Sara Freitas, Josefina Santos, Aline Silverol, Dário Souza pela amizade e companheirismo.

- Os colegas Nildes Pitombo, Sérgio Mindlin pelo contato da empresa pesquisada no Brasil. 
- As pessoas das empresas que participaram do presente estudo e que tão bem souberam compreender o espírito desta pesquisa como elemento colaborador ao desenvolvimento do conhecimento científico na área de administração.

- Ressalvo a importância do apoio desta instituição e seus professores para a realização deste trabalho.

- Os funcionários do PPGA/FEA/USP - Secretarias, Coordenação, Biblioteca, Unidade de Processamento de Dados - pela presteza e constante disposição em atender e em auxiliar.

- A CAPES pelo suporte financeiro fornecido durante todos os anos deste processo.

- Enfim, meu eterno agradecimento a todos aqueles com os quais contraí dívidas de gratidão no decorrer desses anos e cujas palavras e ações estimularam a riqueza e a diversidade de minhas experiências pessoais e profissionais. 


\section{RESUMO}

O empregado precisa de informação para compartilhar do entendimento da visão da organização, construir sentimento de pertencimento, envolver-se e comprometer-se com as estratégias e objetivos da organização. Isso requer interação e diálogo. Assim sendo propõe-se com este estudo verificar os fatores associados ao comprometimento de empregados do setor de telecomunicações, telefonia fixa, segundo estruturas de mercado. Foi realizado um levantamento de informações em fontes primárias, utilizando-se como técnica de abordagem a entrevista por meio do questionário individual, com questões fechadas, na pesquisa quantitativa e por meio de um roteiro semi-estruturado que auxiliou a entrevista individual na pesquisa qualitativa, com a diretoria/ gerência. A pesquisa de campo foi realizada no setor de telecomunicações, no Brasil e em Cabo Verde, no período de janeiro a maio de 2009. A amostra final foi de 98 entrevistados em empresa caboverdeana e 195 em brasileira. Os dados foram submetidos às análises descritivas (tabelas de freqüências e proporções), univariadas (teste de qui-quadrado de Pearson ou exato de Fisher) e múltiplas (regressão logística e de Poisson robusta). Os dados foram analisados, em modelo múltiplo completo: as variáveis do constructo comprometimento no primeiro nível e as sociodemográficas no segundo. Foram consideradas significativas as variáveis com $p<0,05$ ou $p<0,10$. Entre os resultados da pesquisa quantitativa, pode-se registrar que nas duas empresas o processo comunicativo permite a comunicação em todas as direções, com concordância superiores a $85 \%$ em todas as questões. Uma elevada porcentagem, acima de $75 \%$, das pessoas participam de decisões que afetam os seus trabalhos. A existência de vários canais e meios de comunicação utilizados são percebidos pela maioria, com valores acima de $79 \%$. Existe a percepção da maioria, em ordem de $77 \%$, de que existe a área de comunicação e que ela ocupa um espaço estratégico dentro da organização. A pesquisa qualitativa corrobora essa percepção. Os entrevistados concordaram que são comprometidos afetivo, normativo e instrumentalmente em média com 89\%, 70\% e $75 \%$, respectivamente. As diferenças entre tipo de empresas foram significativas na explicação do comprometimento. A estimativa dos coeficientes (modelo de regressão de Poisson e logística) revelam que boa comunicação é um fator associado ao comprometimento. Para uma das empresas, além de uma boa comunicação, alguns fatores sociodemográficos estavam associados positivamente ao comprometimento. As conclusões ratificam a importância da comunicação e de variáveis sociodemográficas no desenvolvimento do comprometimento. Assim, este estudo contribui para o aprofundamento da discussão sobre fatores associados ao comprometimento, com ênfase específica às empresas de telefonia fixa, segundo estruturas de mercado. Além disso, contribui para o aprofundamento da discussão sobre as práticas de gestão de pessoas em mercados de diferentes estruturas. 


\begin{abstract}
The employee needs information to share the understanding of the organization's vision, to build a feeling of belonging, to get involved and to be committed with the organization's strategies and objectives. This requires interaction and dialogue. So, it is proposed with this study to verify the factors associated with the employees' commitment in the telecommunication's sector, fixed telecommunication, according to market structures. A survey of information in primary sources was made, using as a technical approach the interview through the individual questionnaire with closed questions, through individual interviews and quantitative research, in the qualitative research, with the board, through a guide for semi-structured research. The field research was conducted in the telecommunications sector in Brazil and Cabo Verde, from January to May 2009. The final sample was 98 respondents in Cape Verdean company and 195 in Brazilian company. Data were subjected to descriptive analysis (frequency tables and proportions), univariated (chi-square test or Fisher's exact test) and multiple (logistic and Poisson robusta). Data were analyzed, in complete multiple model: the variables in the construct commitment in the first level and the sociodemographic characteristics in the second. It was considered significant the variables with $\mathrm{p}<0.05$ or $\mathrm{p}<0.10$. Among the quantitative research results, it is noteworthy that the two companies, the communication process allows communication in all directions, with over $85 \%$ agreement on all issues. A high percentage, over $75 \%$ of people participate in decisions that affect their work. The existence of various channels and means of communication are perceived by most, with values above $79 \%$. There is a perception of the majority, in order of $77 \%$, that there is a communication area and it occupies a strategic place within the organization. The qualitative research supports this perception. Respondents agree that they are committed affective, normative and instrumentally average of $89 \%, 70 \%$ and $75 \%$ respectively. The differences between types of firms were significant in explaining commitment. The estimated coefficients (Poisson regression model and logistic) indicate that good communication is a factor associated with commitment. For one of the companies, besides the good communication, some socio-demographic factors were positively associated with the commitment. The findings validate the importance of communication and sociodemographic variables in the development of commitment. Thus this study contributes to further discussion on factors associated with commitment, with specific emphasis on fixed telephone companies, according to market structures. It also contributes to deepening the discussion on the human resources management practices in markets differents structures.
\end{abstract}




\section{RÉSUMÉ}

L'employé a besoin d'information pour partager la compréhension de la vision de l'organisation, construire un sentiment d'appartenance, s'engager et se compromettre avec les stratégies et objectifs de l'organisation. Cela demande interaction et dialogue. Ainsi nous proposons au moyen de cette étude de vérifier les facteurs liés à l'engagement des employés du secteur de télécommunications, de téléphone fixe, selon les structures du marché. Nous avons réalisé un relevé d'informations de sources primaires par la technique d'approche de l'interview au moyen d'un questionnaire individuel, avec des questions fermées, à travers un sondage quantitatif et interview individuel et pour le sondage qualitatif, avec la direction et les managers, au moyen d'une technique de sondage semi-structuré. Les recherches sur Le terrain ont été réalisées dans Le secteur de télécommunications au Brésil et au CapVert, entre Janvier et Mai 2009. L'échantillon final a été de 98 interviewés dans une compagnie capverdienne et 195 interviewés dans une compagnie brésilienne. Les données ont été soumises à des analyses descriptives (tableaux de fréquences et proportions) univaridas (test de qui-carré de pearson ou exact de Fisher) et multiples (régression logistique et de Poisson robusta). Les données ont été analysées en modèle multiple complet: les variables d'engagement construit au premier niveau et les variables sociodémographiques au second niveau. Les variables à $\mathrm{p}<0,05$ ou $\mathrm{p}<0,10$ ont été considérées significatives. Entre les résultats du sondage quantitatif nous pouvons noter que dans les deux compagnies les procédés communicationnels permettent la communication dans tous les sens, à une concordance supérieur à $85 \%$ sur toutes lês questions. Un taux élevé, à plus de $75 \%$, des personnes participent aux décisions qui affectent leurs travaux. L'existence de plusieurs canaux et moyens de communication est perçue par la majorité à un taux de supérieur à 79\%. Il y a la perception de la majorité de l'ordre de $77 \%$, qu'il existe un domaine de communication qui occupe un espace stratégique dans l'organisation. Le sondage qualitatif confirme cette perception. Les interviewés reconnaissent qu'ils sont impliqués affectivement, normativement et instrumentalement à en moyenne $89 \%, 70 \%$ e $75 \%$, respectivement. Les différences entre type $\mathrm{d}^{\prime}$ entreprise ont été très importantes pour l'explication de l'engagement. L'estimation des coefficients (modèle de régression de Poisson et logistique) révèlent qu'une bonne communication, quelques facteurs sociodémographiques étaient liés positivement à l'engagement. Les conclusions ratifient l'importance de la communication et des variables sociodémographiques dans Le développement de l'engagement. Ainsi, cette étude contribue à l'approfondissement de la discussion sur les facteurs liés à l'engagement, mettant en exergtue les compagnies de téléphone fixe, selon des structures de marché. En outre, elle contribue aussi à l'approfondissement de la discussion sur les pratiques de gestion de personnes dans des marchés de différentes structures. 


\section{SUMÁRIO}

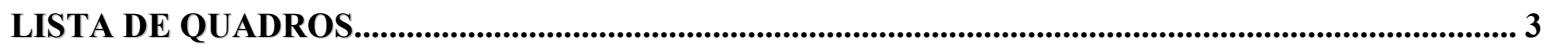

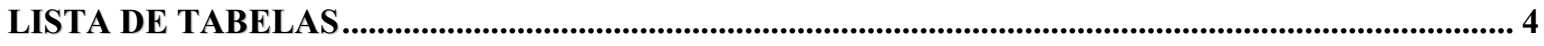

LISTA DE ILUSTRAÇÕES ................................................................................................................................. 5

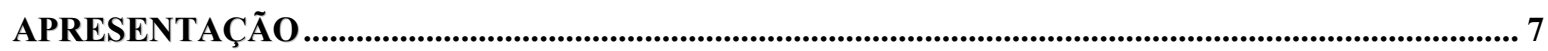

1. INTRODUÇÃ

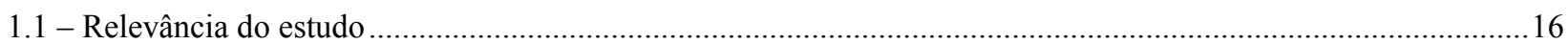

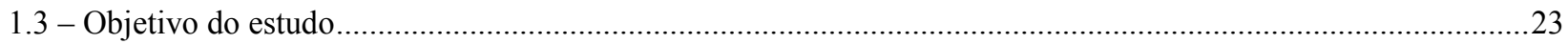

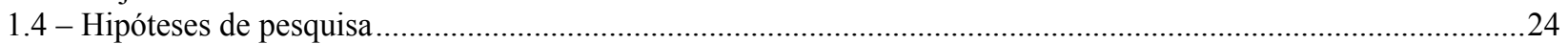

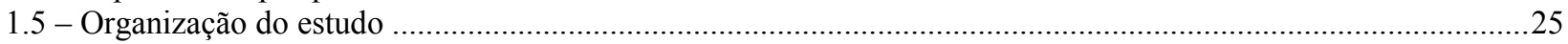

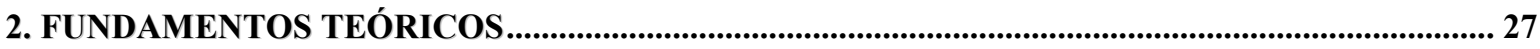

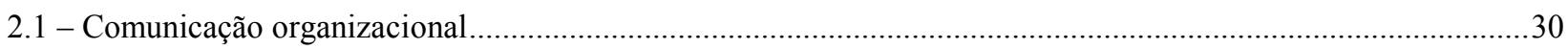

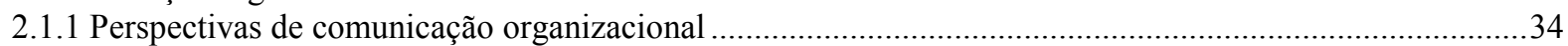

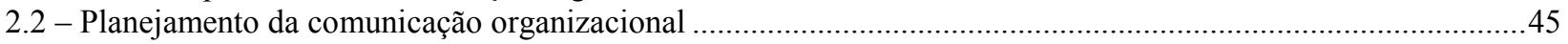

2.2.1 - Componentes que conferem dimensão estratégica à comunicação ..........................................................48

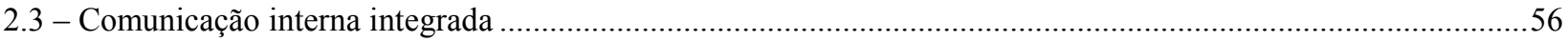

2.3.1 - Importância da comunicação interna versus participação dos empregados ............................................61

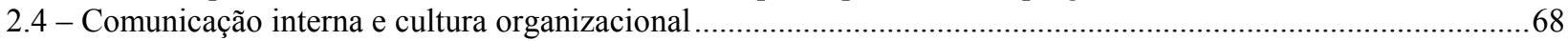

2.5 - O novo contexto organizacional: de gestão de controle à gestão de comprometimento .......................................77

2.5.1 - Estratégia de controle versus Estratégia de comprometimento ........................................................... 81

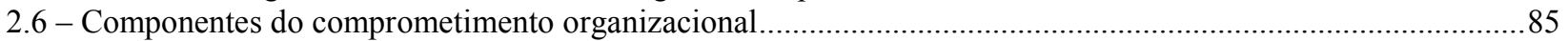

2.7 - Modelos multidimensionais do comprometimento organizacional ....................................................................8

2.8 - Possíveis relações entre comprometimento e comunicação interna ....................................................................93

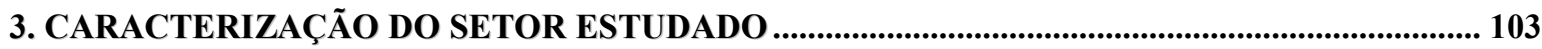

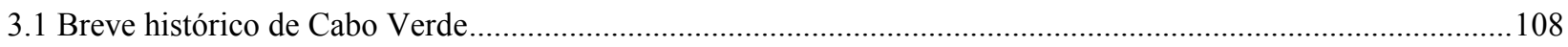

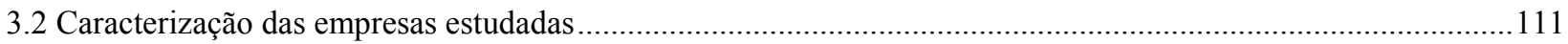

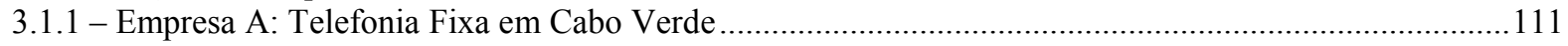

3.1.2 - Empresa B: Telefonia Fixa no Brasil............................................................................................ 112

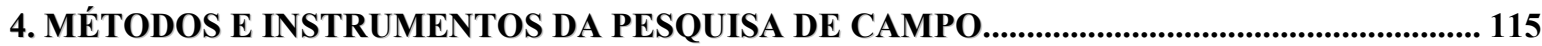

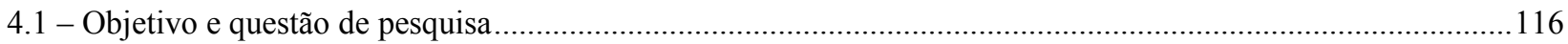

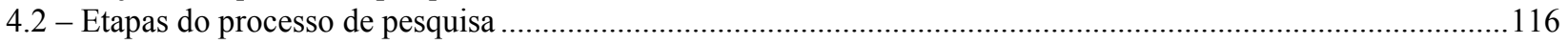

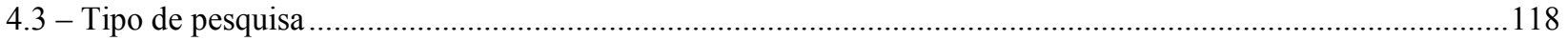

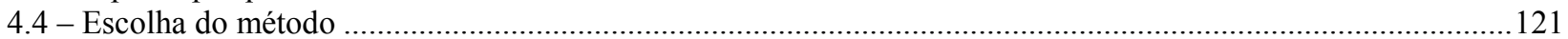

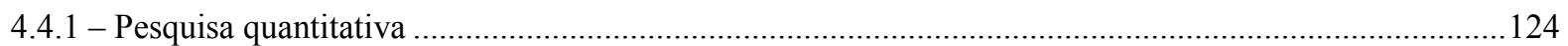

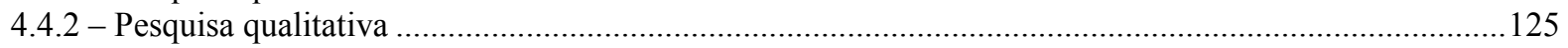

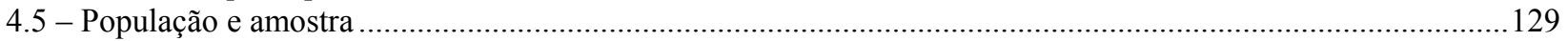

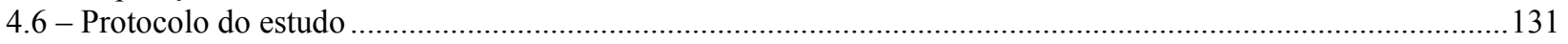

4.7 - Procedimento de coleta de dados e forma de abordagem ........................................................................133

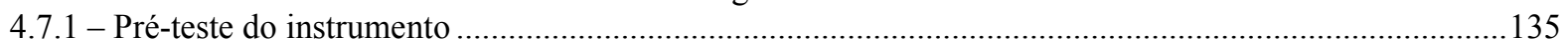

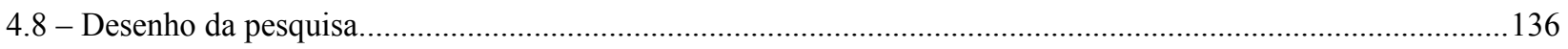

4.8.1 Variáveis independentes: foram designadas de variáveis independentes as sociodemográficas e

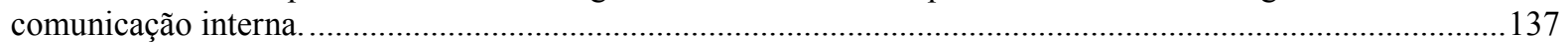

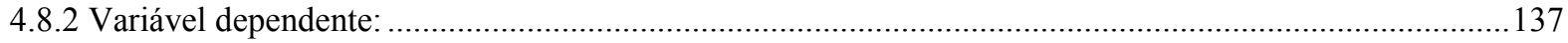




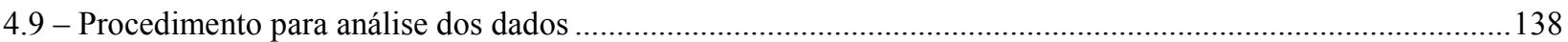

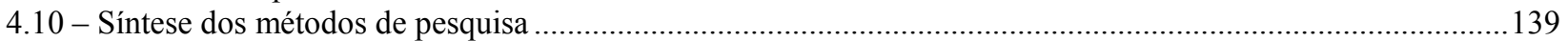

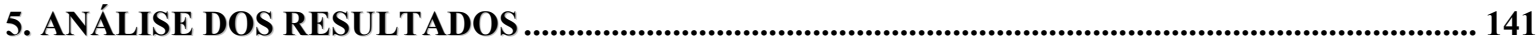

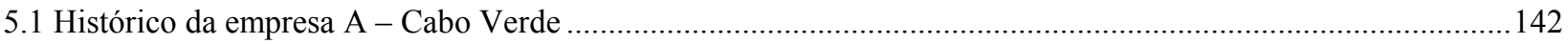

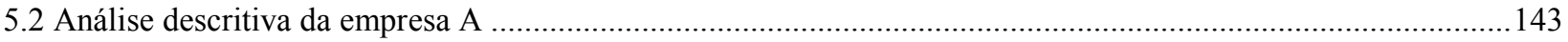

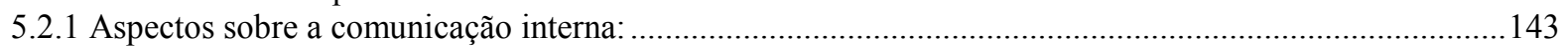

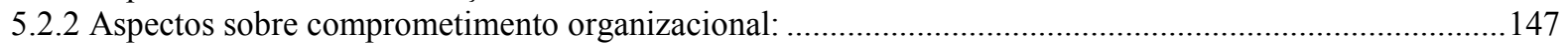

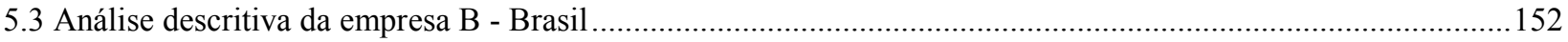

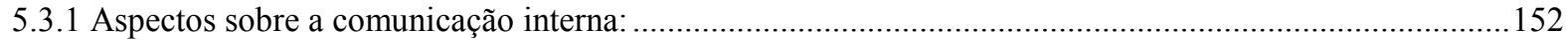

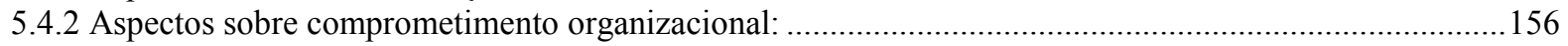

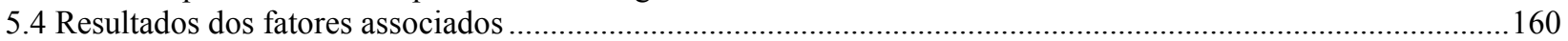

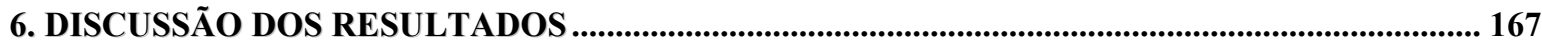

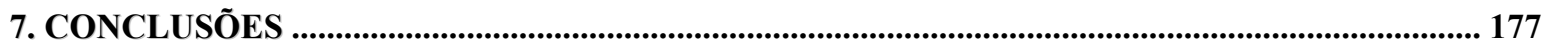

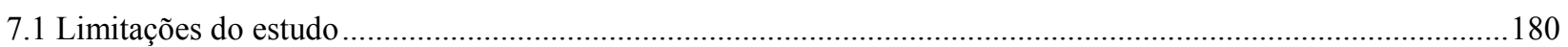

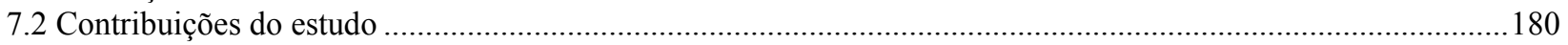

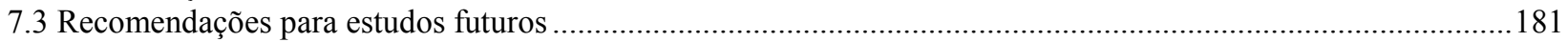

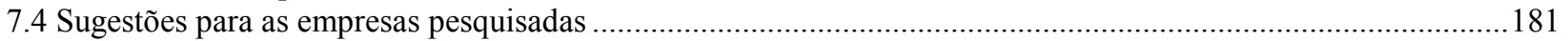

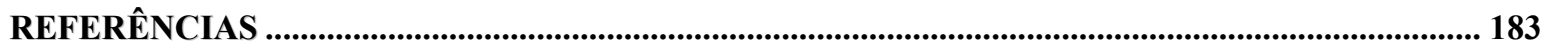

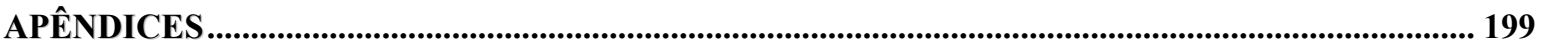

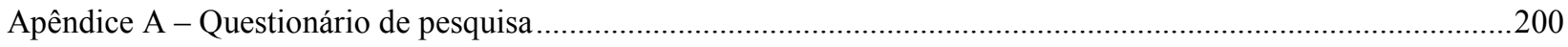

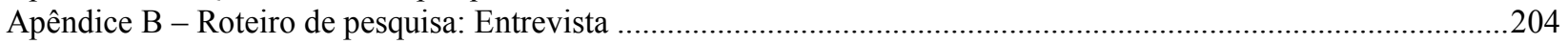




\section{LISTA DE QUADROS}

Quadro 1 - Resumo do estudo.

Quadro 2 - Principais abordagens teóricas de comunicação organizacional. 67

Quadro 3 - Perspectivas multidimensionais de comprometimento. 92

Quadro 4 - Relação entre questão de pesquisa, objetivo e modelo conceitual do estudo.

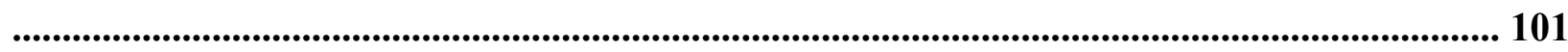

Quadro 5 - Roteiro resumido da pesquisa qualitativa. 128

Quadro 6 - Protocolo de estudo qualitativo.

Quadro 7 - Protocolo de estudo quantitativo. 133

Quadro 8 - Protocolo de estudo quantitativo. 139 


\section{LISTA DE TABELAS}

Tabela 1 - Algumas questões da variável comunicação. Empresa A, Cabo Verde, 2008.

Tabela 2 - Questões referentes à variável comprometimento. Empresa A, Cabo Verde, 2008.

Tabela 3 - Algumas questões da variável comunicação. Empresa B, Brasil, 2008. 153

Tabela 4 - Questões referentes à variável comprometimento. Empresa B, Brasil, 2008. 156

Tabela 5 - Freqüências e proporções de comprometimento segundo características sociodemográficas e relativa à comunicação de funcionários de empresas de Telecomunicações. Empresa A, Cabo Verde, 2008. 161

Tabela 6 - Freqüiências e proporções de comprometimento segundo características sociodemográficas e relativa à comunicação de funcionários de empresas de Telecomunicações. Empresa B, Brasil, 2008. 162

Tabela 7 - Modelos múltiplos logísticos e Poisson na estimativa de Odds ratios e Razão de prevalência de comprometimento ajustados pelas variáveis sociodemográficas e comunicação de funcionários de empresas de Telecomunicações. Empresa A, Cabo Verde, 2008. 164

Tabela 8 - Modelos múltiplos logísticos e Poisson na estimativa de Odds ratios e Razão de prevalência de comprometimento ajustados pelas variáveis sociodemográficas e comunicação de funcionários de empresas de Telecomunicações. Empresa B, Brasil, 2008. 


\section{LISTA DE ILUSTRAÇÕES}

Ilustração 1 - Síntese da revisão da literatura.

Ilustração 2 - Mapa de Cabo Verde.

Ilustração 3 - Mapa do Brasil. 114

Ilustração 4 - Processo de pesquisa em Administração. 117

Ilustração 5 - Tipos de pesquisa.

Ilustração 6 - Tipos de amostragem. 129

Ilustração 7 - Desenho da pesquisa. 137 


\section{APRESENTAÇÃ̃o}

Em uma época que competir exige muito mais do que ter tecnologias de ponta e outros recursos tangíveis, faz-se necessário, para as organizações que almejam sobreviver no mercado, ter empregados comprometidos. Portanto, faz-se necessário que todos os colaboradores estejam engajados com os objetivos organizacionais, para que, assim, se possa assegurar a sinergia e a qualidade nos serviços. Fatores como comunicação interna, planejamento de comunicação e alguns fatores sociodemográficos se destacam como elementos essenciais para o alcance de um comprometimento efetivo. Essa comunicação deve buscar promover canais de comunicação claros, abertos em todos os níveis e segmentos da organização, visando possibilitar uma correta compreensão de seus ambientes e objetivos. Em decorrência, as organizações devem adotar uma estratégia de comprometimento em detrimento da de controle, enfatizando a comunicação dialógica entre todos os níveis hierárquicos e as pessoas consideradas como parceiros no trabalho, nas quais as organizações devem investir para conseguir melhores resultados.

No entanto, as práticas de gestão de pessoas que permitem existência de uma comunicação interna eficaz, nas organizações, está aquém. Comunicação entendida como uma comunicação dialógica, que possibilita a participação de todos os envolvidos. Afinal, comunicação envolve no mínimo duas partes e assim se difere de transmissão de informação. É verdade que na teoria as empresas dizem priorizá-las, mas na prática ainda é o calcanhar de Aquiles. Isso referindo às empresas de uma forma geral, tanto as que atuam em mercados monopolistas como as que atuam em mercados onde existe concorrência acirrada. Porém, nas empresas que atuam em mercados monopolistas as práticas de gestão de pessoas, que possibilitam uma comunicação de fato está ainda deixa a desejar. Talvez pela lógica do mercado em que tudo que é produzido é consumido não é necessário "gastar dinheiro" com coisas do tipo, comunicação com os empregados, dar-lhes possibilidade, por meio de canais e redes, para comunicarem com toda a empresa.

Portanto, o questionamento da postura das empresas, no que se refere às práticas de gestão de pessoas, segundo estruturas de mercado. Num mundo globalizado as preocupações em relação às práticas de gestão de pessoas estão sendo adotadas pelas organizações que atuam em diferentes estruturas de mercado, seja monopólio, seja concorrência? Estudar e entender o 
comprometimento e seus fatores associados, em empresas do setor de telecomunicações que atuam em diferentes estruturas de mercado, a partir da percepção dos empregados constituiu o objetivo desta tese de doutorado.

A partir de uma revisão de literatura que deu sustentação à investigação empírica, por meio de uma pesquisa exploratória, descritiva e transversal, usando o método qualitativo e quantitativo, desenvolveu-se este trabalho que está dividido em sete capítulos. Os resultados apontaram que as preocupações em relação às práticas de gestão de pessoas, nomeadamente comunicação interna e comprometimento, estão presentes tanto na empresa que atua com exclusividade como na que atua num mercado concorrente. 
1. INTRODUÇÃO 
Deparamos, atualmente, com momentos marcados pela ruptura de vários paradigmas causada por mudanças em ritmos acelerados, na tecnologia, na gestão das organizações e nos valores sociais. Estas mudanças têm gerado um ambiente mais volátil e incerto, onde a redução do ciclo de vida dos produtos, o maior nível de exigência dos mercados consumidores, a globalização dos mercados e a produção personalizada vêm alterando a malha da concorrência.

É nesse ambiente que tem-se assistido, por um lado, ao surgimento e à crescente consolidação da empresa excelente, ou seja, aquela que mantém um nível competitivo de adaptação às exigências do ambiente no qual se encontra inserida. Estas mudanças têm alterado a forma de relacionamento entre a empresa e seus empregados, assim como o perfil das pessoas procurado e desenvolvido pelas empresas.

Por outro lado, têm alterado a expectativa das pessoas em relação ao seu trabalho e à empresa tais como: maior oportunidade para desenvolvimento, mais autonomia, mais flexibilidade em relação ao seu encarreiramento e situações de trabalho mais desafiadoras, canais de comunicação que permitem a comunicação em todos os níveis, ou seja, que os empregados expressem seus interesses, por meio de sistemas de sugestões, políticas de portas abertas, pesquisa de opinião, reuniões, etc. e assim conhecer o negócio da empresa como um todo.

As organizações, neste contexto, têm passado por constantes mudanças uma vez que o ambiente impõe novos caminhos e, conseqüentemente, novas estratégias de atuação. Para garantir suas sobrevivências, nesse ambiente, muitas organizações têm adotado ferramentas ou programas tais como Total Quality Control (TQC), Total Quality Management (TQM), Kaizen, Benchmarking, Normas de Qualidade ISO 9000, Reengenharia, Downsizing, entre outros, com o intuito de otimizar os seus resultados.

De acordo com Pereira e Herschmann (2000) as novas tecnologias de comunicação e informação impactaram profundamente a organização do trabalho, com modificações nas estruturas hierárquicas, busca de maior participação e envolvimento dos empregados, ênfase no trabalho de equipe entre outras práticas. A própria implantação de um sistema de gestão baseado nos princípios de Qualidade Total, muito na moda nos anos de 1980 e 1990 e ainda presente na maioria daquelas empresas que os adotaram, depende da capacidade da empresa de desenvolver uma política de gestão de pessoas capaz de envolver e comprometer o trabalhador, uma vez que 
exige do empregado mais conhecimento, mais capacitação e principalmente, disponibilidade e iniciativa para este novo papel, como realçam Ruas e Antunes (1997).

Portanto, o comprometimento, entre outros aspectos, destaca-se como peça-chave para o sucesso das mudanças implementadas. No entanto, toda a reestruturação pode não se justificar se as organizações não entenderem que precisam de colaboradores que se identifiquem com elas e, conseqüentemente, envolvidos e comprometidos com os objetivos organizacionais para que essas organizações possam obter vantagens competitivas e atingir suas metas.

Fischer e Fleury (1996), na pesquisa realizada nas empresas nacionais, ressaltam que as organizações brasileiras têm experimentado uma série de programas administrativos com base na qualidade e produtividade para se manter competitivas. Por outro lado, as empresas precisam ter a consciência de que antes da implementação de qualquer pacote se torna necessário estarem os empregados envolvidos e comprometidos com a causa da empresa. No ambiente de trabalho os ajustes capazes de permitir o alcance da auto-realização e do crescimento dos empregados, que pode provocar aumento no seu nível de comprometimento, devem ser sempre colocados no primeiro plano.

Albuquerque (1999) assevera que o novo cenário em que as organizações atuam, com mudanças constantes, está trazendo grandes impactos para a gestão estratégica de pessoas dentro das organizações. O autor ressalta que há uma evolução do conceito de administração estratégica de recursos humanos que resulta da crescente necessidade de orientação para planejamento e de intervenções gradativas com orientações estratégicas, visando a mudança do modelo de controle onde os empregados são vistos como números, custos e fator de produção, que, para desempenhar bem as suas funções, devem ser mandados e controlados - para o de comprometimento - em que as pessoas são consideradas parceiras no trabalho, nas quais a empresa deve investir para conseguir melhores resultados empresariais.

No presente cenário é exigido que os gerentes administrem, da melhor maneira, a mudança. Dessler (1996, p. 5) ressalta que, portanto, o comprometimento é um importante aspecto a ser gerenciado ao garantir que: 
No ambiente de negócios atual, em que as mudanças acontecem em ritmo acelerado, o futuro pertence aos administradores mais bem-sucedidos em lidar com a mudança, mas para fazê-lo é necessário que haja comprometimento por parte dos funcionários. As empresas ... têm sobrevivido e a maioria prosperado, em parte, porque seus gerentes sabem que, em um mundo de rápidas transformações a vantagem competitiva não reside em máquinas ou patentes, mas em pessoas capazes de improvisar, inovar e investir em si mesmas para o progresso de suas companhias. Em um ambiente de mudanças velozes, os funcionários comprometidos com a empresa tornam-se sua margem competitiva.

Dertouzous et al, (1991) ressaltaram, por meio de uma pesquisa sobre produtividade e qualidade da força de trabalho norte-americana, no final da década de 80, que os trabalhadores norte-americanos são capazes de produzir tão bem quanto os trabalhadores japoneses e alemães, quando trabalham em fábricas gerenciadas por japoneses ou por norte-americanos, desde que incorporem nos seus sistemas de gestão de pessoas as boas práticas, adotadas em empresas japonesas e alemães. Dentre essas boas práticas os autores mencionam as políticas inovativas de recursos humanos. As empresas mais competitivas promovem a participação, o trabalho em equipe e redução de níveis hierárquicos, o aumento das responsabilidades dos seus empregados, dentre outras estratégias. Os autores (op. cit., p. 124) assinalam a relevância do comprometimento da força de trabalho ao assegurarem que:

Empresas bem-sucedidas reconhecem que incrementos na qualidade e flexibilidade requerem níveis de comprometimento, responsabilidade e reconhecimento por parte da força de trabalho que não podem ser obtidos por coerção ou melhorias cosméticas nas políticas de recursos humanos.

Fleury (1997, p. 273) ao analisar as mudanças em curso na indústria brasileira, recentemente envolvida na globalização, corrobora a importância de se estabelecer o comprometimento na força de trabalho, ao discorrer sobre os programas de produtividade e qualidade:

Essa perspectiva alterou também a abordagem dos programas de P\&Q que na primeira fase eram essencialmente centrados no chão-de-fábrica. A questão da Qualidade passou para o nível estratégico e de política corporativa, com as empresas procurando estabelecer suas ações e o comprometimento de seus funcionários a partir de uma visão de empresa, do estabelecimento de sua missão e do compartilhamento de valores. 
Nesse ambiente, o comprometimento dos funcionários torna algo tão almejado pelas organizações, porém nem sempre alcançado. Todas as empresas procuram incessantemente o comprometimento de todos os seus colaboradores com os seus objetivos e que esses colaboradores assumam os seus trabalhos como um desafio e que busquem, sempre, melhores resultados para a sua organização. Assim sendo, o grande desafio das empresas é conseguir um ambiente que faz com que todos os empregados se sintam comprometidos.

Por conseguinte, faz-se mister que a organização tenha uma comunicação interna integrada com políticas globais estabelecidas, estratégias delineadas e programas de ação voltados para todo o pessoal do ambiente interno e dispor de canais e instrumentos diversos que permitam que todas as áreas da organização atuem sinergicamente (KUNSCH, 2003). De acordo com a autora a comunicação integrada tenderá a ser mais eficiente e eficaz.

Concordando, Rego (1986) destaca que o uso sinérgico da comunicação, envolvendo todos os participantes da organização, resultará em melhores condições do ato comunicativo, clarificando os canais, estabelecendo sistemas eficientes de coordenação, gerando respostas mais imediatas e reduzindo, substancialmente, os custos envolvidos com a comunicação.

Diante desse cenário, verifica-se a mudança de postura das organizações em relação à comunicação. O planejamento e a gestão da comunicação organizacional que, geralmente, cabem aos departamentos de Recursos Humanos têm ganhado espaço e assumido pela área de comunicação. De acordo com as pesquisas desenvolvidas em 2002 e 2005, pela ABERJE ${ }^{1}$ (2005) subiu de 49\% para 63\% o percentual de empresas cuja comunicação está sob a responsabilidade das estruturas de comunicação. Já o percentual de organizações que delegam tal responsabilidade aos recursos humanos caiu de 41\% para 38\% de 2002 a 2005. Nesse último caso, percebe-se a presença de profissionais de comunicação nos departamentos de recursos humanos ao lado de especialistas em gestão de pessoas.

Os estudos das revistas Fortune revelam que os executivos das maiores empresas americanas já investem $80 \%$ de seu tempo em comunicação, por considerá-la condição fundamental para o sucesso dos negócios (NASSAR, 2005).

\footnotetext{
${ }^{1}$ Associação Brasileira de Comunicação Empresarial
} 
O autor assevera que as empresas modernas são veículos de comunicação em si mesmas e os gestores cada vez mais têm tratado a comunicação organizacional como ferramenta estratégica, tanto que a sua gestão pode transformar-se em vantagem competitiva para as organizações. Isso fica evidente quando Nassar (2005, p. 18) afirma que:

\begin{abstract}
Em um ambiente empresarial atribulado, em que os cenários traçados pelos estrategistas das altas direções são cada vez mais meras incertezas faz-se necessário guardar como um verdadeiro tesouro tudo aquilo que constrói o imaginário de uma instituição. Missão, visão, identidade, marca são expressões do discurso organizacional que estão permanentemente sob o fogo cerrado de um incrível arco de fatores ligados [...] às reestruturações de ordem econômica, social e política [...] e as organizações que sistematizam o registro desses elementos ligados ao seu simbólico e as comunicam para todos os seus públicos têm as suas identidades fortalecidas, missões protegidas e destinos assegurados.
\end{abstract}

Nota-se que cada vez mais a comunicação é entendida por diretores e presidentes de organizações não só como instrumentos de preservação e realce da imagem da empresa, mas, sobretudo, como elemento indispensável e capaz de agregar valor à conquista de competitividade.

Na visão de Goulart (2007) a comunicação organizacional passou a ocupar lugar de honra entre as ferramentas de gestão somente no final do século $\mathrm{XX}$, o que pode ser conseqüência do cenário econômico mais competitivo. $\mathrm{O}$ autor afirma que na década de 90 verificou-se um grande avanço no entendimento de que a comunicação interna é fundamental para os resultados da empresa. Magalhães (2001, p. 25) corrobora ao asseverar que:

Comunicação empresarial é uma ferramenta estratégica, suporte da administração para todas as atividades da empresa. Ela é maior aliada das atividades de marketing e recursos humanos quando trabalha profissionalmente valores como missão, valor, identidade, parceria, cooperação inter-público e inter-empresa e cidadania empresarial.

A comunicação organizacional, neste contexto, é concebida como um processo importante, pois é o meio pelo qual se faz necessária a sobrevivência da organização. De acordo com a literatura, a comunicação interna é parte do processo de comunicação da organização com seus stakeholders e que merece abordagens e tratamentos específicos. Young e Post (1995) asseveram que os empregados de uma organização são um de seus stakeholders primários mais 
importantes e como tais precisam de informações para que possam contribuir para o alcance dos objetivos da organização.

Conseqüentemente, no mundo moderno, o planejamento desempenha um papel decisivo nas organizações de todos os tipos e, em decorrência deste fato, as organizações têm de atuar como sistemas abertos, criando novos canais de comunicação, pois no contexto da globalização, comunicar-se com competência tornou-se condição para o crescimento e sobrevivência das organizações. Albuquerque (2002) defende a participação mais ampla de colaboradores de diferentes níveis da organização na formulação da estratégia como uma forma de tornar o processo estratégico mais interativo e contínuo, estimulando a comunicação, o aprendizado e o comprometimento das pessoas.

Compartilhando da mesma opinião Fischer e Fleury (1992) destacam a importância do envolvimento dos colaboradores na elaboração e implementação de estratégias. Para estes autores, os ajustes são capazes de permitir o alcance da auto-realização e do crescimento dos colaboradores e podem provocar aumento no seu nível de comprometimento.

Essa atitude estratégica tem como intuito dar aos funcionários uma noção da importância de um serviço orientado para atender aos clientes, a capacidade de responder a dúvidas que surgirem dentro da companhia, e isso inclui envolvimento, comprometimento, valorização e, principalmente, qualificação do funcionário, visando assumir responsabilidades e iniciativas, conhecendo todas as rotinas de serviço da organização onde atuam. Afinal, uma informação errada dada ao cliente externo ou uma imagem negativa pode comprometer todo o desenvolvimento de um projeto.

O colaborador deve saber a importância do lugar onde trabalha, da sua contribuição e do seu papel dentro da organização, pois só assim ele poderá ter um bom ambiente de trabalho e de equipe. A comunicação interna é importante para o sucesso de qualquer empresa e a confiança do público, tanto o interno como o externo, é uma conseqüência da mesma. Assim, a comunicação interna pode assumir um papel importante no crescimento dos negócios das organizações num cenário competitivo e exigente. 
Coda (1997) realça essa importância, afirmando que a comunicação com os empregados em tempos de mudança, envolve ao mesmo tempo: informação relevante para o trabalho, compreensão do que as pessoas querem, uso de canais adequados para a comunicação, feedback para que se exerça a criatividade, assim como o reconhecimento do bom trabalho realizado.

$\mathrm{Na}$ mesma linha de pensamento encontra-se Bateman (2003) defendendo que os empregados de uma organização têm o direito de ser informados das questões básicas sobre as suas atividades e que a organização tem a responsabilidade por esta comunicação.

Ao se buscarem referenciais globais de excelência das empresas nota-se a importância do envolvimento dos funcionários nesse processo. São, então, desenvolvidos mecanismos no contexto da comunicação interna que agilizem e tornem possível essa integração dos funcionários com as mudanças que estão acontecendo dentro das empresas.

Portanto, uma das maiores responsabilidades da administração é responder às necessidades que os funcionários têm de informação qualificada, pois eles precisam receber informações claras sobre o que precisa ser feito, o que se espera deles, a forma de realização do trabalho, espaço para participarem das decisões relevantes para o seu dia-a-dia dentro da organização, assim como conhecer todo o negócio da organização.

Sendo assim, a comunicação e o comprometimento são vistos como umas das variáveis norteadoras de uma política de gestão com vistas à construção de uma gestão de pessoas estratégica cuja finalidade é fornecer a todos os colaboradores a oportunidade e a possibilidade de conhecer a organização como um todo e atuarem em busca do alcance dos objetivos organizacionais.

\section{1 - Relevância do estudo}

$\mathrm{Na}$ exploração da dimensionalidade do comprometimento, os modelos de conceitualização de mais de um componente do comprometimento têm ganhado espaço. A pesquisa na área está longe de chegar a um consenso também nesse aspecto, tornando o 
comprometimento um conceito em construção. Meyer e Allen (1991, p. 82), na conclusão do trabalho que estabeleceu as bases teóricas do modelo de três componentes do comprometimento, afirmam que não é claro que os três componentes estabelecidos são os únicos componentes relevantes do comprometimento ou que cada um represente um constructo unitário. Para os autores (Meyer; Allen, 1997), é necessário mais trabalho no estudo dos componentes do comprometimento organizacional, apesar da atenção que já tem sido dispensada sobre o tema.

Seguindo essa linha, diversos outros estudos também têm defendido a realização de uma maior investigação da dimensionalidade do comprometimento organizacional (MATHIEU; ZAJAC, 1990; BASTOS, 1993; MEYER; ALLEN, 1997; MOWDAY, 1998; MEDEIROS et al, 2003).

Mowday (1998, p. 396) aponta como futura direção para a pesquisa do comprometimento organizacional: (i) avançar na compreensão do processo através do qual determinados trabalhos e práticas organizacionais produzem comprometimento; (ii) verificar se o comprometimento pode ser uma variável interveniente, ligando os sistemas de RH ao desempenho organizacional. Para o autor essa pesquisa talvez seja o desenvolvimento mais excitante nesse campo de estudo em muitos anos; (iii) estabelecer claramente se o comprometimento organizacional é uma variável importante entre os sistemas de recursos humanos e os resultados organizacionais; (iv) verificar se o comprometimento organizacional é mais interessante em determinados ajustes organizacionais do que outros, com relação à obtenção de resultados financeiros positivos; (v) desenvolver novas metodologias de coleta e mensuração do comprometimento.

Mowday et al, (1979) e Mathieu e Zajac (1990) asseveram a necessidade de aprender mais sobre os principais antecedentes e conseqüentes do comprometimento organizacional. No Brasil, a recomendação de pesquisa que foi desenvolvida é a em relação aos antecedentes, em que as cinco variáveis descritas na meta-análise de Mathieu e Zajac (op. cit.) foram tratadas: características pessoais; características do trabalho; relações com o grupo/líder; características organizacionais e variáveis funcionais.

Medeiros (2003) desenvolveu um estudo, visando explorar a dimensionalidade do comprometimento organizacional, ajustado à cultura brasileira, estabelecendo relações do comprometimento com um conjunto de antecedentes, características organizacionais, que influem 
no comprometimento e de conseqüentes a ele. Como resultados, validou, no setor hoteleiro do nordeste brasileiro, um modelo com sete dimensões de comprometimento, a partir do modelo de Meyer et al, (1993) e O’Reilly e Chatman (1986).

Chang Jr. (2001), com o intuito de elaborar e propor um modelo amplo e sistêmico que contenha as principais variáveis explicativas do comprometimento organizacional, efetuou um estudo de caso comparativo na Nortel Networks do Brasil e no Metrô de São Paulo - Brasil. Como resultado do estudo, o autor incluiu a variável comunicação como sendo conseqüente ao comprometimento e criatividade como antecedente.

Há estudos também a respeito do comprometimento organizacional em instituições de pesquisa. Borges-Andrade et al, (1990) obtiveram como resultados de um estudo na Embrapa que as variáveis mais poderosas para o comprometimento, tanto para os pesquisadores como também para os colaboradores das áreas administrativas, são a existência de um sistema justo de promoções e de oportunidades de crescimento na carreira e no progresso profissional e a influência que a instituição exerce no ambiente externo. Destacam-se ainda como variáveis relacionadas positivamente ao comprometimento dificuldade de ingresso na instituição, percepção da organização como sendo influente no país, satisfação com o relacionamento com os colegas e interesse despertado pelas atividades que realizam. Com relação ao pessoal de suporte à pesquisa, o comprometimento é condicionado por aspectos pessoais e de papel organizacional, sendo também muito importante o funcionamento dos grupos de trabalho e distribuição de tarefas.

Meyer e Allen (1997) ressaltam a pouca necessidade em se desenvolver novos estudos que examinem correlações bivariadas, mas sim conduzir estudos em que o design da pesquisa seja adequado para mostrar uma relação de causa e efeito mais complexa. Nesta linha, Chang Jr. (2001), utilizando a modelagem de equações estruturadas, técnica de estatística avançada, em seu estudo incluiu duas variáveis: comunicação como conseqüente e criatividade como antecedente.

Tavares (2005); Tavares; Limongi-França $(2005 ; 2009 ; 2010)$ ao tratarem da importância da comunicação interna para o desenvolvimento do comprometimento organizacional, constataram que existe uma forte associação e dependência entre a comunicação interna integrada e o comprometimento organizacional. 
Autores como Likert (1971); Thayer (1976); Mishra (2007); Alexander et al, (2009); SamGnanakkan (2010); Tomlinson (2010) embora não tendo como objetivo de estudo verificar a existência de correlação entre a comunicação e o comprometimento, apontam a existência de uma associação entre comunicação e comprometimento.

Verifica-se que a abertura de um espaço para o desenvolvimento da comunicação interna, buscando integração de todas as pessoas que fazem parte da instituição para que elas possam conhecer e tomar parte do negócio como um todo é o resultado do mercado cada vez mais competitivo. Nesse mercado, as organizações estão permanentemente procurando maior produtividade, por meio de mudanças e adaptações nas estruturas, estratégias, políticas, cultura da organização, etc., visando, assim, o posicionamento no mesmo.

A pesquisa sobre comunicação interna realizada pela DATABERJE em 2002 e 2005 junto a empresas das mais distintas origens - com predominância para as brasileiras $(51,3 \%), 16,2 \%$ americanas, 31,8\% européias - evidencia a importância da comunicação nas organizações. Os resultados mostram que a área de comunicação tem status de vice-presidência, diretoria ou superintendência em $46 \%$ da amostra. Em 35\% das corporações a área de comunicação figura como uma gerência. Em 8,5\% dos casos a área de comunicação é uma assessoria; em 6\% é coordenadoria e em 4,3\% é um departamento. Ainda de acordo com os resultados da pesquisa a comunicação corporativa é a área estratégica para a maioria dos entrevistados $(74,4 \%)$ e em 73,5\% delas já existe um Plano Integrado de Comunicação. Nas empresas onde a área já é uma diretoria este índice chega a 91,1\%. A comunicação interna está migrando para a área corporativa. Em 2002, a comunicação interna estava vinculada à corporativa em $49 \%$ dos casos. Em 2005, este índice chega a 63,2\% das empresas (DATABERJE, 2006).

Albuquerque (1999) ao apresentar um modelo que possibilita às empresas aumentarem sua competitividade empresarial, com contornos de uma estratégia de comprometimento da força de trabalho para a busca de resultados empresariais e de vantagens competitivas sustentáveis, destaca o papel do processo de comunicação da empresa como fator fundamental na estratégia de comprometimento negociado.

No século XXI muitos executivos compreendem que a competição acirrada requer aprendizado mais eficaz, amplo empowerment e maior comprometimento de todos nas empresas. 
Neste contexto a chave para um bom desempenho é um alto nível de comunicação (ULRICH, 2003).

Jablin e Putnam (2001) corroboram, asseverando que muitas organizações já perceberam que as assim chamadas questões internas - sua organização da produção, seu uso dos recursos, o manejo do desperdício e seu tratamento com os empregados - potencialmente comunicam uma forte mensagem para o mundo externo.

Fischer e Albuquerque (2004), no relatório Delphi 2010, survey realizada junto a profissionais com cargo de direção ou gerência em áreas de recursos humanos de empresas do ranking das 500 maiores e 100 melhores para se trabalhar do Brasil, além de professores e consultores referentes às tendências na gestão de pessoas apontam como uma das principais tendências observada quanto à gestão estratégica de RH a busca de participação dos gerentes na formulação e implementação das estratégias corporativas $(74,7 \%)$. Os gestores de RH também estão envolvidos com a concepção e disseminação dessas estratégias (66,1\%). Também aparece a utilização de meios eletrônicos na relação e prestação de serviços aos funcionários - e-RH, incorporada em 46,8\% e 47,9\% na primeira e segunda rodada, realizadas em 2001 e 2003, respectivamente.

Portanto, observa-se o destaque e a importância decisiva da comunicação interna no contexto organizacional. Porém, vale realçar que as técnicas tradicionais de comunicação, aquelas que normalmente são utilizadas para sistematizar, divulgar e expressar informações, por exemplo, boletins e jornaizinhos internos, jornais murais, vídeos institucionais, pesquisas de clima são úteis na produção de informação sobre questões rotineiras e para a produção de dados quantitativos para suporte a programas de gestão, como, por exemplo, gestão da qualidade total (TQM) e reengenharia. Ressalta bem Argyris (1990) que eles não possibilitam que as pessoas reflitam sobre o seu trabalho e comportamento além de não trazerem à superfície os tipos de informações profundas e potencialmente ameaçadoras e embaraçosas que podem motivar a aprendizagem e produzir mudança real.

Faz-se necessário que a comunicação seja estratégica e, por conseguinte, planejada e inserir o empregado como protagonista no processo de planejamento e comunicação, estabelecendo uma ação gerencial dialógica onde o entendimento, o comprometimento e os 
conseqüentes resultados podem ser surpreendentes. De acordo com Tenório (2000) a circulação de informações, favorecida em grande parte pelos veículos modernos da comunicação digital contribui para uma maior participação de diferentes atores na estrutura hierarquizada das organizações.

As organizações que têm como filosofia de gestão a estratégia de controle, rígido, altamente hierarquizada com comunicação vertical se limita à transmissão de informações aos empregados, o que pode impossibilitar a participação dos mesmos na vida da organização. Corrado (1994) assevera que a comunicação mais eficiente com os empregados é vista como meio para melhorar a produtividade e proporcionar um entendimento das metas organizacionais. Entende-se que, para o autor, a melhor comunicação com os empregados é aquela que traz resultados na produtividade da organização. Corrado (op. cit.) realça a importância da comunicação dentro das organizações e a necessidade de terem políticas de comunicação claras e bem definidas, defendendo que os administradores devem associar o comportamento dos empregados com as estratégias da organização.

Chanlat (1996) assevera que o ser humano é único enquanto espécie, sendo fundamentalmente biopsicossocial. Está ligado à natureza e à cultura que o envolve e que ele mesmo transforma. Porém, o autor ressalva que os empregados são considerados pelas organizações, na maioria das vezes, apenas recursos, como quantidades materiais que devem apresentar um rendimento satisfatório, sendo comparados em alguns casos como ferramentas, equipamentos e matéria-prima.

No entanto, existe uma idéia de que está havendo uma transformação nos modelos que concebem o homem no seu ambiente de trabalho. De acordo com Losicer (1995) o ser humano está deixando de ser um simples recurso, fazendo com que as organizações procurem entender este novo paradigma que se estabelece. O autor destaca que não há possibilidade de sobrevivência para nenhum modelo de gestão que não se adaptar às novas concepções do mercado.

Para tanto, a boa gestão de pessoas vai além das funções de selecionar, treinar e desenvolver e passa a ter como uma de suas funções a descoberta da dimensão subjetiva em todos os níveis do processo organizacional. Tal dimensão não é quantificável, está intimamente ligada 
aos sistemas de qualidade que se realizam com o reconhecimento dos empregados envolvidos, integrada com a relação intersubjetiva.

$\mathrm{Na}$ perspectiva de Losicer (op. cit), as organizações têm de passar da estratégia de controle, rígido, altamente hierarquizada com comunicação vertical, onde os empregados são vistos como números, custos e fator de produção, que para desempenharem bem as suas funções precisam ser mandados e controlados para o modelo mais flexível, estratégia de comprometimento, que enfatiza a comunicação horizontal, empowerment, onde as pessoas são consideradas como parceiros no trabalho, nas quais as organizações devem investir para conseguir melhores resultados.

Será que isso ocorre com as organizações em todos os contextos e, inclusivamente, as que atuam em mercados nos quais as estruturas são diferentes, ou seja, monopólio e oligopólio?

Em decorrência de tudo que já foi exposto acima, destaca-se como motivações mais importantes para desenvolvimento deste estudo:

- Escassez de estudos sobre o setor de telecomunicações, no que se refere à gestão de pessoas, numa perspectiva comparada entre Cabo Verde e Brasil. Por isso se propôs desenvolver um estudo numa perspectiva comparativa entre os dois países, visando verificar fatores associados ao comprometimento nas empresas do mesmo setor, segundo estruturas de mercado.

* Crescente debate sobre políticas de gestão de pessoas em todo o mundo, emergindo assim práticas comuns globalmente. As empresas de telecomunicações, especificamente as de telefonia fixa, se caracterizaram, até recentemente, em quase todos os países como monopólio, sendo o fenômeno de privatização ocorrendo após os anos 90, inclusive no Brasil e em Cabo Verde.

* A relevância de se analisar as peculiaridades do modelo de gestão de pessoas de empresas do mesmo setor, porém que atuam em contextos diferentes, uma com exclusividade de mercado e outra atuando num mercado competitivo, no qual conta com a multiplicidade de empresas prestando o mesmo serviço. 
As estruturas de mercado podem favorecer ou não a prática de gestão de pessoas que possibilita a participação de todos na vida da organização, priorizando, assim, uma comunicação interna dialógica, com intuito em obter o comprometimento e envolvimento de todos no negócio da organização. No entanto, nas pesquisas realizadas, não foi identificado nenhum estudo sobre comportamento organizacional que abordasse os fatores associados ao comprometimento, quais seja comunicação e variáveis sociodemográficas, segundo estruturas de mercado (monopólio e oligopólio $)^{2}$. Assim, para preencher esta lacuna, desenvolveu-se este estudo.

Não pretendemos esgotar o assunto neste trabalho e sim chamar a atenção para a importância estratégica de práticas de gestão de pessoas que possibilitem o desenvolvimento de comprometimento organizacional dos colaboradores com os objetivos organizacionais, em contextos diferentes.

\section{2 - Problema de pesquisa}

A pergunta que motivou o desenvolvimento deste estudo é a seguinte: fatores sociodemográficos e comunicação interna são associados ao comprometimento?

\section{3 - Objetivo do estudo}

Torna-se imperativo o comprometimento dos funcionários para a excelência da organização num ambiente altamente competitivo. Este comprometimento com os objetivos organizacionais, por sua vez, pode ser impossibilitado num ambiente sem uma comunicação interna integrada. Desta forma, pretendemos, com este estudo, verificar fatores associados ao comprometimento de colaboradores do setor de telecomunicações, telefonia fixa, segundo estruturas de mercado.

\footnotetext{
${ }^{2}$ Monopólio - é um caso extremo de concorrência imperfeita em que um único vendedor tem o controlo total da oferta de determinado produto ou serviço. Oligopólio - situação de mercado em que um número reduzido de vendedores controla toda a oferta de serviços ou mercadorias (COSTA; MELO, 1999).
} 


\section{4 - Hipóteses de pesquisa}

Para orientar o esforço de pesquisa, foram formuladas as seguintes hipóteses:

$\mathrm{H}_{1 \mathrm{~A}}$ : Variável comunicação interna influencia o comprometimento dos colaboradores.

$\mathrm{H}_{1 \mathrm{~B}}$ : Variáveis sociodemográficas influenciam o comprometimento dos colaboradores.

$\mathrm{H}_{1 \mathrm{C}}$ : Variáveis sociodemográficas são moderadoras no estudo de associação entre as variáveis comunicação interna e comprometimento.

$\mathrm{H}_{1 \mathrm{D}}$ : Variável comunicação interna é moderadora no estudo de associação entre as variáveis sociodemográficas e comprometimento.

O quadro 1, a seguir, apresenta de forma resumida os pontos principais do estudo. 
Quadro n 1 - Resumo do estudo

\begin{tabular}{|c|c|c|c|c|}
\hline Pergunta & Objetivos & Metodologia & Hipóteses & Resultados \\
\hline $\begin{array}{c}\text { Fatores } \\
\text { sociodemográf } \\
\text { icos e } \\
\text { comunicação } \\
\text { interna são } \\
\text { associados ao } \\
\text { comprometim } \\
\text { ento? }\end{array}$ & $\begin{array}{l}\text { Verificar fatores } \\
\text { associados ao } \\
\text { comprometiment } \\
\text { o de empregados } \\
\text { do setor de } \\
\text { telecomunicações } \\
\text {, telefonia fixa, } \\
\text { segundo } \\
\text { estruturas de } \\
\text { mercado. }\end{array}$ & $\begin{array}{l}\text { Revisão } \\
\text { Literatura; } \\
\text { Levantamento } \\
\text { quali } \\
\text { Entrevista por } \\
\text { meio de um } \\
\text { questionário semi- } \\
\text { estruturado com a } \\
\text { gerência e } \\
\text { diretoria das } \\
\text { empresas. } \\
\text { Levantamento } \\
\text { quanti } \\
\text { Questionário auto- } \\
\text { administrativo } \\
\text { preenchido pelos } \\
\text { funcionários. } \\
\text { Análise dos } \\
\text { resultados } \\
\text { Técnicas } \\
\text { estatísticas: } \\
\text { 1. Análise } \\
\text { descritiva. } \\
\text { 2. Teste Qui- } \\
\text { quadrado de } \\
\text { Pearson ou Exato } \\
\text { de Fisher. } \\
\text { 3. Regressão } \\
\text { logística e de } \\
\text { Poisson robusto } \\
\text { (Backward } \\
\text { stepwise Wald). }\end{array}$ & 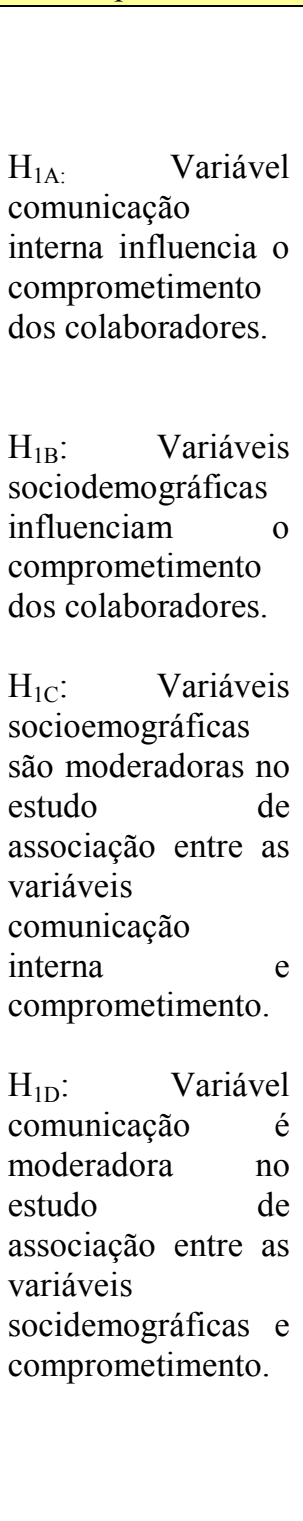 & $\begin{array}{l}\text { 2. Existe uma alta associação e } \\
\text { positiva entre } \\
\text { comprometimento } \\
\text { comunicação interna. As } \\
\text { diferenças entre tipos de } \\
\text { empresas foram significativas } \\
\text { na explicação } \\
\text { comprometimento. } \\
\text { diferentes estruturas de } \\
\text { mercado interferem nos } \\
\text { fatores associados } \\
\text { comprometimento ao } \\
\text { organizacional. Para uma das } \\
\text { empresas pesquisadas além de } \\
\text { uma boa comunicação, alguns } \\
\text { fatores sociodemográficos } \\
\text { estão associados } \\
\text { positivamente a } \\
\text { comprometimento. }\end{array}$ \\
\hline
\end{tabular}

\section{5 - Organização do estudo}

A tese está dividida da seguinte forma. No primeiro capítulo será apresentada uma introdução dividida em partes: na primeira parte, a relevância do estudo, abordando temas comunicação interna e comprometimento organizacional; em seguida o problema de pesquisa; 
seguindo o objetivo da pesquisa; as hipóteses do trabalho e, por último, um quadro com resumo do estudo.

No capítulo dois será apresentada uma revisão bibliográfica que compreende três grandes partes: a primeira descrevendo as principais vertentes conceituais da comunicação organizacional; a segunda apresentando as teorias do comprometimento organizacional, em seguida, apresenta-se as teorias sobre cultura organizacional e a última parte apresenta as possíveis relações entre comprometimento organizacional e comunicação interna. Em seguida, no capítulo 3, encontra-se a caracterização do setor estudado. No capítulo quatro, estará exposta a metodologia da pesquisa, onde se apresenta a natureza e o método; o universo e amostra da pesquisa realizada com os funcionários das organizações selecionadas; os procedimentos de coleta de dados; os instrumentos de mensuração utilizados. O quinto capítulo trará os resultados da pesquisa e as análises dos mesmos. No capítulo seis a discussão dos mesmos.

Finalmente, no capítulo sete será apontada algumas considerações em relação a este estudo. No decorrer do capítulo são apresentadas as contribuições do trabalho e limitações do mesmo assim como algumas recomendações para futuros trabalhos de pesquisa.

Ao final dos sete capítulos seguirá as referências, os apêndices, nos quais podem ser encontrados os instrumentos de pesquisa de campo. 


\section{FUNDAMENTOS TEÓRICOS}


Para contextualizar, fundamentar, situar e melhor compreender o fenômeno estudado foi realizada a revisão da literatura sobre o tema escolhido. Deste modo, nesta seção será focada as reflexões sobre assuntos tais como comunicação interna, planejamento da comunicação e comprometimento organizacional e como estes podem se relacionar.

Portanto, a organização desta seção está composta por quatro partes: na primeira parte estão apresentados os principais conceitos do composto de comunicação organizacional; na segunda parte são apresentadas as vertentes do comprometimento organizacional; na terceira parte, as interfaces da comunicação interna e cultura organizacional e na última parte discorre-se sobre as possíveis relações entre comprometimento e comunicação interna.

Comunicação organizacional é o composto de comunicação que ocorre nas organizações e pode ser dividida em comunicação interna e comunicação externa. O foco do nosso trabalho é a comunicação interna, ou seja, a que se dá entre os colaboradores e a organização.

O composto de comunicação ou comunicação integrada, como descreve Kunsch (2006b) divide-se em três áreas: comunicação administrativa, comunicação institucional e comunicação mercadológica. Estes três estágios de comunicação formam o composto de comunicação de uma organização e deverão harmonizar os setores e sub-setores da organização. Na concepção da autora a comunicação integrada fecha um ciclo de comunicação ao redor da organização, integrando a organização e propiciando uma uniformidade no fluxo de informações, contribuindo com a adequação da organização ao cenário mercadológico. Quando existe um planejamento da comunicação organizacional e, conseqüentemente, a interação sinérgica, envolvendo todos os segmentos da comunicação, a comunicação interna tende a ser integrada e mais eficaz.

No presente estudo a noção de comunicação interna eficaz está ligada à existência de comunicação interna estratégica e planejada, dispondo de canais e instrumentos diversos que permitem a atuação sinérgica de todas as áreas da organização e possibilitem uma comunicação dialógica.

Apesar de não ser o escopo deste trabalho, dada a especificidade das organizações e das culturas nas quais elas estão inseridas, entendeu-se pertinente fazer uma breve revisão deste assunto, pois tanto a cultura como a comunicação organizacional são reflexos da filosofia de 
administração e estão interligadas. Ou seja, a comunicação é o espelho da cultura organizacional e reflete necessariamente os valores da organização, que se caminharem para valorizar o profissionalismo, a transparência, a responsabilidade social e a participação contribuem para que a comunicação também se orienta no mesmo sentido, estimulando a participação de seus colaboradores, permitindo, assim, a circulação das informações e para a implementação de canais de comunicação formais e informais que possibilitem o relacionamento entre todos os colaboradores da organização. Uma outra justificativa para abordar esse assunto, ainda que de forma superficial, é porque toda a organização tem um conjunto de comportamentos, saberes e saber-fazer característicos de um grupo humano, denominado por alguns autores de cultura organizacional. Portanto, os comportamentos pertinentes a uma determinada organização são adquiridos por meio de um processo de aprendizagem e transmitidos ao conjunto de seus membros. Isto necessariamente envolve comunicação.

A comunicação tem ganhado expressão dentro das organizações, principalmente nas últimas décadas, conseqüência de fatores tais como: pressão competitiva pela qual as organizações vêm passando nas últimas décadas, impulsionada pela competição internacional intensiva; crescimento desacelerado e mercados em declínio que têm obrigado as organizações a reduzirem custos e darem foco ao valor agregado pelas pessoas, processos e estratégias. Tudo isso tem permitido que produtos e serviços sejam fabricados e ofertados ao mercado mundial pelo menor preço possível, mesmo sob condições de mercado instável, mediante fontes globais de matérias-primas, tecnologia, capital e capital humano. Assim, de acordo com Pastore (1995) a organização somente conseguirá vencer essa competição e se prosperar por meio da cooperação entre empregados e empregadores e flexibilização das relações de trabalho, isto é, ajustando-se às novas condições e tirando delas o máximo proveito.

Daí verificar-se a mudança de enfoque de gestão de pessoas e a procura de comprometimento dos colaboradores, pois o grande desafio é o de se conseguir nas organizações um ambiente de alto comprometimento, ou seja, identificar ambientes organizacionais que comprometem os empregados.

Nesse sentido, encontram-se vários estudos com o intuito de identificar as variáveis que contribuem para causar o comprometimento, enfocando componentes determinantes desse comprometimento: antecedentes, conseqüentes e correlatos. 
Apesar da diversidade de conceitos sobre comprometimento, a generalidade dos autores que se interessam por esta área, entende-se tratar-se de uma força que promove, estabiliza ou obriga a determinados comportamentos e que parece influenciar o bem-estar dos empregados dentro das organizações, contribuindo para promover a eficácia das mesmas.

Dentre os conceitos de comprometimento organizacional, será usado, neste trabalho, o conceito de Meyer e Allen (1990) que defendem o modelo tri-dimensional que consiste na divisão do comprometimento em comprometimento afetivo, instrumental e normativo que os autores explicam, argumentando que: empregados com um forte comprometido afetivo permanecem na organização porque eles querem; aqueles com comprometimento instrumental permanecem porque eles precisam e aqueles com comprometimento normativo permanecem porque eles sentem que são obrigados.

Ao final do capítulo, será apresentada uma ilustração com a síntese dos assuntos explorados no decorrer do capítulo e que dará sustentação à investigação empírica.

\section{1 - Comunicação organizacional}

$\mathrm{Na}$ era da informação, a maior e mais duradoura vantagem competitiva vem do conhecimento. O sucesso das organizações está no domínio da informação em tempo real, conhecimento das tecnologias digitais de comunicação e na segurança e dinamismo dos processos, sejam eles tecnológicos ou humanos. Elas precisam reunir pessoas qualificadas, confiáveis e com elevado espírito de trabalho em equipe, capazes de atuar como empreendedores, serem pro-ativos e terem ampla autonomia para tomada de decisões em relação às tarefas.

Por conseguinte, a organização do conhecimento deve encontrar novas soluções para responder rapidamente aos clientes, criar novos mercados, desenvolver e combinar com agilidade novos produtos e tecnologias. Em decorrência deste cenário, a qualidade é imprescindível e é preciso que os conhecimentos individuais sejam socializados, articulados, combinados e internalizados (NONAKA, 2000). Pelo compartilhamento do conhecimento, dá-se o compartilhamento do poder e o comprometimento com os objetivos da organização não é estabelecido por meio de ordens, mas sim pelo compartilhamento da visão. 
Diante desses desafios, a participação ativa dos empregados no processo comunicativo é inevitável e as ações de comunicação interna mostram-se como meio de interação contínua entre organização e funcionários, para alinhar e harmonizar objetivos individuais e organizacionais.

Nos dizeres de Castells (1998) ocorre hoje uma nova forma de relação entre economia, estado e sociedade, resultado da revolução tecnológica que está na base da chamada sociedade da informação. Na sociedade globalizada, a comunicação assume grande relevância, fazendo-se, mais do que nunca, necessário repensa-la no contexto das organizações inseridas no processo.

De acordo com Kunsch (2003) não há mais como pensar em atitudes isoladas de comunicação, sem o envolvimento de todos os setores da comunicação organizacional. Daí a importância da comunicação integrada para a sobrevivência e o desempenho de uma organização em uma realidade complexa e que se altera de forma muito rápida.

Portanto, a comunicação organizacional em geral e a interna em particular apresentam como uma ferramenta fundamental para que as organizações consigam ser bem-sucedidas. As capacidades de compartilhamento, em tempo real, de mensagens e informações e de conversão das informações em conhecimento são, na atualidade, as competências vitais para qualquer organização.

Rodríguez de San Miguel (1996) argumenta que comunicação organizacional pode ser definida por um conjunto de técnicas e atividades para facilitar e agilizar o fluxo de mensagens entre os membros da organização ou entre a organização e o meio, influindo nas opiniões, atitudes e comportamentos dos públicos internos e externos da organização para que esta cumpra melhor e mais rapidamente seus objetivos.

O autor divide, assim, a comunicação organizacional em duas partes: a interna, dirigida ao pessoal da organização e a externa quando dirigida aos diferentes públicos externos da organização. Na concepção de Kunsch (2003, p. 149-150) o termo comunicação organizacional é mais abrangente, ao firmar-se que:

Fenômeno inerente aos agrupamentos de pessoas que integram uma organização ou a ela se ligam, a comunicação organizacional configura as diferentes modalidades comunicacionais que permeiam sua atividade. Compreende dessa forma a comunicação institucional, a comunicação mercadológica, a comunicação interna e a comunicação administrativa (...) O termo 'comunicação organizacional' que abarca todo o espectro 
das atividades comunicacionais apresenta maior amplitude, aplicando-se a qualquer tipo de organização - pública, privada, sem fins lucrativos, ONG's, fundações, etc, não se restringindo ao âmbito do que se denomina 'empresa'.

De acordo com a autora a comunicação organizacional é imprescindível para qualquer tipo de organização e engloba todos os tipos de comunicação com os públicos interno e externo.

Goldhaber (1991), partindo da concepção que a organização é um sistema vivo e aberto, conectado por um fluxo de informações entre as pessoas que ocupam diferentes posições e representam distintos papéis, define a comunicação organizacional como sendo um processo dinâmico por meio do qual as organizações se relacionam com o meio ambiente e as subpartes da organização se conectam entre si por um fluxo de mensagens processadas em uma rede de relações interdependentes. Esta definição apresenta quatro conceitos-chave a serem considerados nas atribuições da comunicação organizacional: mensagens, rede, relações e interdependência.

As mensagens tratam a informação significativa sobre pessoas, ações e objetos gerados durante as interações humanas. Dizem respeito à informação que é percebida e para a qual os receptores atribuem um significado. As mensagens, as informações significativas fluem por meio de redes de comunicações, as quais por sua vez, estão conectadas às pessoas, estabelecendo entre elas diferentes graus (intensidade) de relações. As redes são canais formais e, principalmente, os informais que distorcem o sentido das mensagens. $\mathrm{O}$ autor aponta várias possibilidades para $\mathrm{o}$ estudo dessas relações. Por intermédio da conduta das pessoas envolvidas nessas relações, dos seus efeitos em relações específicas, bem como por intermédio de habilidades, atitudes e moral dos empregados quando afetados ou quando afetam as relações dentro da organização. As relações são a base da comunicação organizacional, sendo as pessoas a peça principal. Destaca assim o aspecto de interdependência, isto é, ao considerar a organização como um sistema aberto admite-se a coexistência de subsistemas os quais estabelecem entre si níveis de interdependência, ou seja, esses sistemas afetam e são afetados mutuamente, afetando, portanto, o sistema como um todo. A interdependência deve ser um fenômeno bastante claro e de extrema importância para os administradores. Este fenômeno caracteriza-se pela formalidade ou informalidade. Cabe aos gestores saber canalizar este fluxo a favor da organização. 
A comunicação organizacional como descreve o autor deve ser entendida como um processo composto por métodos, estratégias, fluxos, redes e meios responsáveis por interligar as diferentes partes componentes da organização.

Hall (1984) estuda a comunicação organizacional, considerando os fatores que afetam o envio, o recebimento, a percepção e as interpretações dessas comunicações. A comunicação é um processo relacional - emissor/receptor - isto é, as relações sociais que se processam entre ambos, os envolvem como seus efeitos recíprocos à medida que se comunicam.

O autor alerta para uma série de fatores que dificultam as comunicações nas organizações, destacando que o processo de comunicação deve ser encarado como um processo dinâmico em que novos atores, novos meios e novas definições entram, constantemente, em cena.

Kreps (1990), por sua vez, com uma outra abordagem, entende a comunicação organizacional como um processo por meio do qual os membros da organização obtêm as informações pertinentes sobre ela e as mudanças que nela ocorrem. Na visão deste autor, a comunicação organizacional desempenha uma função de fonte de informação para os membros da organização. A informação constitui na variável intermediária que une a comunicação à organização. Essa abordagem coloca a comunicação na condição de mera transmissora de informações, sem considerar a necessidade de interação própria do processo e que a função da comunicação organizacional ultrapassa a condição de fonte de informação.

Restrepo e Angulo (1995) enfatizam que a comunicação nas organizações deve ser entendida de forma integral, permeando todas as ações organizacionais, viabilizando de maneira permanente a construção de sua cultura, identidade e marcando um estilo próprio e suas formas de projetar-se exteriormente. A organização é entendida como unidades coletivas de ações constituídas para atingir fins específicos e dirigidas por um poder que estabelece uma forma de autoridade que determina o status e o papel de seus membros. A organização pode ser percebida como uma expressão particular e concreta de sistema de ação histórica e de relações de classe e como uma atividade regulada por decisões que emanam de um sistema político. A comunicação pode ser entendida e percebida como um composto que dá forma à organização, que a informa e a faz ser o que ela é. 
Os autores estabelecem quatro dimensões do processo de comunicação organizacional:

Como informação (o que dá forma), enquanto configurador das operações próprias de cada organização. São as transações estáveis que necessitam ocorrer para que o negócio se viabilize, o sistema normativo (missão, valores, princípios, políticas entre outros) que sustenta a prática da organização, as formas de controle;

* Como divulgação, no sentido de dar a conhecer, tornar público;

* Como gerador de relações voltadas para a formação, socialização e ou reforço de processos culturais. Atividades recreativas, rituais e celebrações são alguns dos processos de comunicação utilizados nessa dimensão;

* Como participação, caracteriza a ação de comunicação do outro. Aqui se completa o ciclo de comunicação, no qual explicitamente se dá a palavra ao outro, escutando-o e reconhecendo-o. São os trabalhos de equipe, os programas de sugestões, ou seja, todas as práticas organizacionais que oportunizem a efetiva participação, estabelecendo vínculos de pertinência e compromisso com a organização.

A perspectiva de Restrepo e Angulo traz à tona uma questão crucial do ponto de vista da relação comunicação-organização, ou seja, a maneira de ser de uma organização pode ser interpretada pelas formas de comunicação que ali são desenvolvidas, implicando reconhecer as diversas organizações como construtoras de sentido.

\subsubsection{Perspectivas de comunicação organizacional}

Na mesma linha de Goldhaber (1991) e considerando que a comunicação organizacional diz respeito aos processos de comunicação que caracterizam as organizações humanas, Daniells, et al, (1997) identificaram-na a partir de três modelos ou perspectivas de comunicação organizacional: tradicional, interpretativo e crítico. 
a) No modelo tradicional a comunicação organizacional é vista como uma atividade cujo comportamento pode ser medido, padronizado e classificado, existe uma relação entre processo comunicacional e eficiência organizacional. Nessa abordagem podem ser identificados dois momentos: primeiro, ao considerar a organização como máquina (visão mecanicista), a comunicação organizacional é tida como uma engrenagem, um processo mecânico; segundo, sob uma perspectiva mais recente, a organização é entendida como sistema e a comunicação organizacional um processo orgânico e dinâmico. Aqui percebe-se aspectos evolutivos de comunicação organizacional.

b) O outro modelo é o interpretativo que entende as organizações como culturas. Aqui a organização é um fenômeno subjetivo, ou seja, a ação social somente é possível quando as pessoas compartilham significados. As pesquisas interpretativas buscam revelar as realidades socialmente construídas nas organizações. Estudam a comunicação como processo por meio do qual essa construção social ocorre, ou seja, os símbolos e os significados que envolvem as várias formas de comportamento organizacional. A organização é vista também como espaço de negociação. Portanto, essa perspectiva concentra-se no processo simbólico, por meio do qual a realidade organizacional é socialmente construída. E essa realidade organizacional é socialmente construída por meio da comunicação, isto é, a realidade é criada e mantida pela interação entre os empregados.

Contrariamente à perspectiva tradicional em que há um entendimento de que o mundo da ação social, interação se constitui em comportamentos observáveis e tangíveis, a perspectiva interpretativa tenta revelar que a cultura é o que está por detrás desses comportamentos manifestos. Verifica-se que esse modelo enfatiza a indissociabilidade entre comunicação e cultura organizacionais, posicionando a comunicação como o meio que viabiliza a realidade organizacional com todo o seu conjunto de significados e símbolos, sendo assim mais que uma fonte transmissora de informação.

c) Já a perspectiva crítica aborda a organização como instrumento de opressão. Aqui a ênfase é dada aos trabalhadores, mulheres, minorias e outros grupos identificados como classes oprimidas. A comunicação nesta perspectiva é tida como instrumento de dominação. Trata-se da distorção sistemática da comunicação, a qual se constitui uma ação deliberada e contínua do 
processo simbólico, visando cooptar os interesses dos empregados. A associação entre comunicação e cultura pode ser conduzida em várias direções, com objetivos diversos de acordo com os interesses da organização (CHANLAT, 1996).

Goodall Jr e Eisenberg (1997) identificam cinco modelos de comunicação organizacional: (i) comunicação organizacional como transferência de informação; (ii) como processo transacional; (iii) como estratégia de controle; (iv) como equilíbrio entre criatividade e constrangimento/ coação/ sujeição e (iv) como espaço de diálogo, entendido como comunicação equilibrada, ou seja, a comunicação em que cada empregado tem a oportunidade de falar e ser ouvido.

Os autores usam a metáfora do encanamento, por meio do qual a informação é transferida, escoa, no sentido de ser repassada de uma pessoa para outra, para caracterizarem a comunicação como transferência. É a comunicação assimétrica e, geralmente, é utilizada para transferir metas, objetivos da cúpula para os demais membros da organização. É um modelo linear, simplificado e incompleto, uma vez que entende que cabe ao emissor definir o significado das mensagens, repassando-o aos demais. Ou seja, o emissor transmite uma mensagem a um receptor, que atua como ente passivo. Percebe-se que, a exemplo da abordagem de Kreps (1990), esse modelo trata a comunicação numa perspectiva de passividade do receptor, própria da comunicação instrumental, reduzindo sua importância no ambiente organizacional.

O modelo transacional dá ênfase ao feedback, isto é, como a mensagem é recebida e entendida, por meio da manifestação não verbal, a qual pode substituir o feedback verbal. Para esse modelo o que interessa é o comportamento manifestado, não apenas o expresso verbalmente. O processo do modelo transacional difere do modelo de transferência de informação por considerar o significado da mensagem como é recebida e entendida, ou seja, como o receptor irá construir o significado da mensagem. Nota-se que ao considerar o significado que o receptor atribui à mensagem, o modelo avança em relação àqueles que entendem a comunicação como transferência de informação e valoriza o receptor, considerando o seu universo cognitivo.

O outro modelo, o de controle estratégico considera a comunicação como uma ferramenta de controle do ambiente organizacional. Este modelo atribui aos comunicadores objetivos múltiplos face a situações, ou seja, um comunicador competente é aquele que seleciona 
adequadamente as estratégias para a realização de múltiplos objetivos na organização. Esse modelo sugere que o mundo organizacional é composto por comunicadores independentes, cada um trabalhando para controlar o seu próprio ambiente e que os significados existem apenas na mente das pessoas.

Ao aliar a comunicação ao alcance dos objetivos organizacionais sem considerar o compartilhamento de significados como base na comunicação, esse modelo trata a organização como uma máquina, a exemplo do modelo tradicional de Daniels et al, (1997). Defende-se que em um contexto organizacional participativo, a relação entre comunicação e objetivos organizacionais acontece a partir do entendimento de comunicação como um processo produtor de sentido que influencia e é influenciado (processo relacional); da percepção da organização como um sistema aberto e da compreensão dos envolvidos como entes que possuem universos cognitivos diferenciados e que são simultaneamente receptores e transmissores.

O quarto modelo apresenta a comunicação do ponto de vista do equilíbrio entre a criatividade e a sujeição. A comunicação atua como fiel da balança entre a criatividade, o que poderá ser feito, e a sujeição, o que deve ser feito. Nota-se uma preocupação com duas importantes variáveis do ambiente organizacional: a organização em si com suas normas e procedimentos, organizando a ação - o que deve ser feito - sua cultura e clima organizacionais (ambiente de interpretação) e o sujeito com seus significados, criatividade e capacidade de interpretação para promover mudanças (o que poderá ser feito). E a comunicação figura como mediadora dessas tensões que possam surgir da interação entre o que pode ser feito e o que deve ser feito.

Os autores sugerem um quinto e último modelo que considera as organizações como espaço de diálogo. O diálogo é entendido como comunicação equilibrada, ou seja, a comunicação em que cada empregado tem a oportunidade de falar e ser ouvido. Percebe-se um alargamento do conceito de comunicação nesse modelo, ao vislumbrar a possibilidade do equilíbrio de oportunidades, lembrando a simetria de duas mãos de Grunig (2003). O modelo simétrico de duas mãos tem como objetivo principal a compreensão mútua. A sua comunicação persegue o equilíbrio de interesses, o entendimento entre os públicos que se relacionam. Corroborando Mishra (2007) indica que a comunicação de duas vias, possibilita a prática de uma comunicação excelente. 
Putnam et al, (2004) posicionaram a comunicação como produtora das organizações e propuseram estudá-la a partir de sete linhas de metáforas, representando os diferentes ramos de pesquisa da comunicação organizacional. Essas metáforas são identificadas como: conduite, lente, linkage, perfomence, símbolo, voz e discurso. Segundo os autores, as metáforas são modos alternativos de pensar sobre a origem e a natureza do ato de organizar seus processos e conceitos que formam suas raízes ontológicas.

Deste modo, a metáfora do conduíte refere-se ao encaminhamento da comunicação, considerando as organizações como canais ou containeres. A comunicação, nesta ótica, é entendida como transmissão. Enviar, trocar, transmitir são as palavras que sinalizam o seu uso. Portanto, a comunicação é basicamente uma mão única e é um canal, uma tecnologia ou uma tarefa que os membros da organização devem realizar. A metáfora da lente admite que as organizações filtrem a comunicação, na medida em que são consideradas como sistemas perceptuais ou olhos que tudo vêem e percebem. Por essa lente, a comunicação é filtrada e freqüentemente distorcida em virtude de passar por várias membranas entre a organização e o ambiente, entre departamentos e empregados. A diferença entre essa metáfora e a primeira é que nesta os emissores são agentes ativos no processo. A metáfora do linkage entende que as organizações são redes ou sistemas de empregados interconectados e a comunicação age para conectá-los. A metáfora da performance projeta a comunicação como interação social [...] e as organizações emergem como ações coordenadas. Na metáfora do símbolo, por sua vez, as organizações emergem da cultura organizacional, projetando a comunicação como interpretação de formas literárias, tais como narrações, os ritos e rituais e os paradoxos. A metáfora da voz considera que a comunicação é expressão e a organização é um coro de vozes. Engloba vozes distorcidas, vozes de dominação e acesso à voz por intermédio de práticas democráticas e participativas. Metáforas dentro dessa categoria de voz incluem distorção de comunicação e supressão de conflito. Ter uma voz é ser capaz de falar no contexto da organização. Mas nem todos têm uma voz igual, nem todos os membros do coro cantam ao mesmo tempo. A metáfora do discurso considera a comunicação como conversação, na qual as organizações aparecem como textos que consistem em gêneros e diálogos. Os autores valeram-se das metáforas para fazerem diferentes (re) leituras sobre as modalidades que a comunicação assume no âmbito organizacional (PUTNAM et al, 2004, p. 71-106). 
Verifica-se que a comunicação interna é um processo por meio do qual os membros da organização obtêm as informações pertinentes sobre ela e as mudanças que nela ocorrem. A informação e o conhecimento, transparente, sem distorções e coerções, se constituem numa variável muito importante que une a comunicação à organização. De acordo com Forrester apud Mishra (2007) o benefício da organização ao promover uma comunicação interna eficaz é tornar os empregados embaixadores da marca da empresa.

Considerando que a comunicação organizacional diz respeito aos processos de comunicação que caracterizam as organizações humanas, ela deve ser entendida de uma forma total, interpondo em todas as ações da organização, viabilizando de maneira constante a construção de sua cultura, identidade, marcando um estilo próprio e suas formas de projetar-se exteriormente a construção de sua própria imagem. A comunicação, então, é um composto que dá forma à organização que informa e a projeta, fazendo-a ser o que é.

Kunsch (2003) entende que a comunicação organizacional designa todo o trabalho de comunicação levado a efeito pelas organizações em geral. A autora propõe que as organizações concebam a sua comunicação a partir de uma perspectiva integrada, abrangendo as comunicações institucional, mercadológica, interna e administrativa que formam o mix, o composto da comunicação organizacional, ou seja, a convergência de todas as atividades com base numa política global, claramente definida e nos objetivos gerais da organização, possibilitando ações estratégicas e táticas de comunicação mais pensadas e trabalhadas com vistas à eficácia. Trata-se, na verdade, de uma filosofia que direciona a convergência das diversas áreas, permitindo uma atuação sinérgica.

A comunicação institucional refere-se à "[...] construção e formatação de uma imagem e identidade corporativas fortes e positivas de uma organização" (KUNCH, 2003, p. 164), enquanto que a comunicação mercadológica volta-se para a divulgação dos produtos e serviços de uma organização, compreendendo toda a manifestação gerada em torno dos objetivos de venda de uma organização. Para a autora, essa comunicação está diretamente relacionada ao marketing de negócios. Ambas, ressalvando as suas diferenças e especificidades, implementam ações destinadas, prioritariamente, aos públicos externos da organização ao contrário da comunicação administrativa e interna que necessitam priorizar os seus públicos internos. 
A comunicação administrativa envolve os procedimentos comunicacionais que ocorrem na organização. A comunicação interna se desenvolve paralelamente à comunicação administrativa e visa proporcionar meios para promover maior integração dentro da organização, mediante o diálogo, a troca de informações e experiências e a participação de todos os níveis.

Rego (2002) destaca que o uso sinérgico da comunicação resultará na maximização do processo de comunicação, resultando numa comunicação mais eficaz. Segundo esse autor, o uso sinérgico da comunicação, envolvendo todos os participantes da organização resultará em melhores condições do ato comunicativo, clarificando os canais, estabelecendo sistemas eficientes de coordenação, gerando respostas mais imediatas e reduzindo, substancialmente, os custos envolvidos com a comunicação.

Concordando, Kunsch (2006b) ressalta que a comunicação integrada com políticas globais estabelecidas, estratégias delineadas e programas de ação voltados para todo o pessoal do ambiente interno, tenderá a ser muito mais eficiente e eficaz.

Nassar (2005) corrobora essa idéia ao asseverar que o status de comunicação integrada é fundamental para a criação de valor perene para a organização, pois na atualidade os públicos percebem as organizações por qualquer uma de suas vertentes comunicacionais e não só pela comunicação mercadológica que antes era a que recebia mais atenção por parte das organizações.

Para Rego (2002) a comunicação organizacional é a possibilidade sistêmica que integrada reúne as modalidades de comunicação cultural, comunicação administrativa, comunicação social e sistemas de informação (REGO, op. cit., p. 35). A comunicação cultural, diz respeito ao clima interno, isto é, se um gerente e um diretor querem saber o que está a passar ao seu redor devem medir a temperatura do clima organizacional, aferida a partir da cultura interna, que é o arcabouço dos costumes, das idéias e dos valores organizacionais. A comunicação administrativa refere-se à comunicação oficial da organização, reunindo papéis, cartas internas, ofícios, memorandos. A comunicação social compreende as áreas de jornalismo, relações públicas, publicidade, editoração e marketing. Para o autor é a mais desenvolvida do ponto de vista conceitual quanto dos pontos de vista operacional e tecnológico. Os sistemas de informação, por sua vez, agregam as informações armazenadas em bancos de dados. 
Neves (2003, p. 23) ao descrever a integração das ações em comunicação, defende como base para a existência de um ambiente de comunicação organizacional integrada um processo que integra todas as funções que se relacionam com os públicos ou que fazem algum tipo de comunicação. Para o autor, nada impede que as funções tenham suas estratégias próprias e independentes, desde que no momento da comunicação organizacional, as ações sejam coordenadas.

O conceito de comunicação integrada para a comunicação organizacional é mais abrangente, pois vê a organização como um todo, sem distinção entre as áreas ou subáreas.

As modalidades apresentadas por Kunsch (2003) e Rego (2002), embora distintas, buscam dar conta da complexidade da comunicação das organizações com seus diferentes segmentos de públicos, enfatizando a necessidade da comunicação ser pensada de forma integrada e estratégica.

Laswell (1998) assevera que uma forma conveniente de descrever um ato de comunicação é a que surge das respostas às seguintes questões: Quem? Diz o quê? Em que canal? A quem? Com que efeito? Os estudos que se dedicam a estudar a resposta ao "quem", são os que avaliam os fatores que iniciam e guiam o ato de comunicação. Essa abordagem vincula-se aos fluxos de comunicação dentro da organização: descendentes, quando dos superiores para os subalternos; ascendentes, dos subalternos para os superiores; laterais, quando entre pessoas de mesmo nível; diagonal, quando um superior troca mensagens com um subalterno localizado em outra área ou departamento.

Já Limongi-França (2007) e Sakyi (2010) ao descreverem a comunicação interna indicam dois fluxos: a descendente e ascendente, diferentemente de outros autores Laswell (1998); Kunsch (2003) que apontam outros fluxos da comunicação interna, usando as redes formais e informais.

Ressalta-se que no enfoque gerencial da abordagem clássica existe um desprezo do papel da comunicação ascendente e lateral, tendo sido dada importância apenas à comunicação descendente, como forma de comando e controle dos donos e gerentes sobre os subalternos e o processo de trabalho. 
Os que se preocupam em responder ao "diz o que" trabalham a questão do conteúdo das mensagens. Dentro de uma organização há uma multiplicidade de mensagens e conteúdos distintos, do tipo formal e informal. O domínio do conteúdo e a sua adequação para os distintos públicos dentro de uma organização são fatores muito importantes para uma comunicação eficaz. De acordo com Rego (2002, p. 28), freqüentemente, as fontes têm dificuldade em dominar os temas. Ou não entendem profundamente do tema ou não sabem expressar idéias a respeito dele.

Os estudos que enfatizam o "em que canal" enfocam os meios utilizados para se comunicar, ou seja, os canais utilizados na comunicação organizacional.

Os que se preocupam em responder ao "a quem" fazem análise da recepção das mensagens, tendo como um dos seus objetivos a redução da ocorrência de mal-entendidos. A compreensão do público receptor e a capacidade de antecipar a forma como a mensagem será recebida é um grande desafio para os profissionais de comunicação organizacional. As mensagens são interpretadas e entendidas em contextos sociais específicos, de acordo com a cultura organizacional. Segundo Rego (2002, p. 42) "se um gerente não conhece a natureza - o perfil, gostos, atitudes, expectativas, vontades, a realidade cotidiana - dos receptores com os quais se comunica ou quer se comunicar vai provocar ruídos em sua comunicação".

Percebe-se que existem os que analisam a eficiência (medida de desempenho) e a eficácia (êxito ou fracasso) dos processos comunicativos organizacionais, preocupando-se com os efeitos produzidos pelas mensagens.

Entende-se que a comunicação organizacional abrange todas as formas ou modalidades de comunicação utilizadas e desenvolvidas pela organização para relacionar-se e interagir com os seus públicos.

A teoria da administração baseada em equipes se caracteriza, essencialmente, pela comunicação multidirecional nas organizações. Assume destaque o papel dos líderes, identificados como responsáveis por gerar grupos de trabalhos fortes e coesos. Segundo Uribe e Zuliaga (2003) essas perspectivas impactaram significativamente as organizações e fortaleceram as práticas de comunicação. 
Nota-se que vários são os estudos no campo da comunicação organizacional e com enfoques diferentes: funcionalista, estruturalista, teoria da informação ou teoria matemática da comunicação de Shannon e Weaver (1949). No entanto, a corrente funcionalista tem maior influência no Brasil, pois a maioria dos trabalhos da área é desenvolvida, visando explicar os processos de comunicação nas organizações, apresentando as funções e disfunções das mensagens.

A partir da perspectiva funcionalista a preocupação maior dentro das organizações é com a utilização da comunicação como ferramenta necessária para as funções de coordenação do trabalho em prol da realização das metas, manutenção de um padrão de comportamento, adaptação e integração das organizações e de seus funcionários, seja internamente, seja externamente.

Para este estudo a abordagem adotada também será a funcionalista, uma vez que propomos compreender a comunicação em organizações, a partir do entendimento dos processos de comunicação nelas e partilhamos da mesma opinião de Kunsch (2006b) e Corrado (1994) de que a comunicação interna integrada tende a melhorar a produtividade e comprometer os colaboradores com os objetivos organizacionais.

É importante ressaltar que a comunicação integrada assume como pressuposto básico a sinergia e a integração entre as diversas áreas, ferramentas e necessidades da comunicação organizacional. Pressupõe um processo de planejamento estratégico que precede o uso de toda e qualquer ferramenta, requer uma visão acurada e abrangente das necessidades comunicacionais da organização cujo resultado final contribui para a construção da sua imagem interna e externa.

A partir da breve revisão teórica da comunicação organizacional e considerado o contexto social e organizacional contemporâneo, pode-se extrair alguns pressupostos importantes que permeiam a discussão sobre o assunto e que cada vez mais orientam o processo comunicacional nas organizações. Daí defende-se que a comunicação nas organizações:

* Deve ser estratégica, ou seja, deve ser elemento do planejamento global da organização, a fim de agregar valor e gerar resultados; 
* Deve ser integrada, envolvendo todas as áreas da comunicação, estimulando a interação e participação de todos, privilegiando todos os interlocutores e viabilizando o diálogo;

* Esse diálogo deve ser ampliado com a interatividade e a possibilidade do receptor participar do processo comunicativo, a partir da introdução de novas tecnologias de informação e de comunicação que, conseqüentemente, possibilitará a interação que vai além dos instrumentos tradicionais;

* Deve considerar a cultura organizacional e a diversidade de significados que compõem o processo comunicacional, portanto não deve ser padronizada e sim diferenciada de acordo com o contexto e os públicos;

* Deve, assim, ultrapassar a condição de mera fonte transmissora de informação, que transfere mensagens de forma linear para públicos passivos, como forma de se fazer conhecer e alcance o patamar de processo relacional produtor de sentidos (MARCHIORI, 2006).

Para que haja uma comunicação integrada que transmite uma mensagem única, consistente e transparente, ela precisa ser planejada. Portanto, a comunicação tem de ser uma ferramenta de gestão que gera coesão, agrega valor e constitui uma comunicação que flui em todos os níveis, por meio das redes formais e informais. Por meio dessas redes a comunicação percorre a organização, visando a troca de informações para que todas as instâncias mantenham foco nos objetivos e metas, desempenhando suas tarefas e papéis conscientes da missão e imbuídos da filosofia da organização.

Comunicação dirigida com foco, orientada para resultados duradouros, pressupõe alinhamento de temas de maneira sinérgica em todos os veículos e isso funciona como uma potente alavanca organizacional. Alinhamento esse requer planejamento, cooperação e não concorrência de canais, políticas de comunicação bem definidas e liderança comprometida e capacitada. 
De acordo com Marchiori (2006) somente com o detalhamento do contexto é que se pode planejar e alcançar eficácia na comunicação. A autora salienta que a abertura de canais, a construção de diálogos, o reconhecimento das relações entre líderes e liderados e a busca da performance são caminhos pelos quais a ação da comunicação terá forte efetividade nas organizações.

A comunicação estratégica sugere que as intervenções comunicacionais devam dar-se de forma planejada, concebidas em antecipação à ação e dirigidas a públicos-alvo.

Dentre as várias terminologias para se referir ao termo comunicação nas organizações (comunicação organizacional, empresarial, institucional, corporativa entre outras), adotou-se para este trabalho o termo comunicação organizacional.

\section{2 - Planejamento da comunicação organizacional}

O planejamento estratégico tornou-se uma ferramenta valiosa às organizações. Por meio deste, as organizações podem desenvolver uma visão do futuro da sociedade, prever possíveis acontecimentos e selecionar estratégias adequadas para enfrentá-los. Em decorrência deste cenário, a comunicação torna-se um fator indispensável às organizações para a obtenção de resultados e a comunicação interna, por sua vez, passa a merecer uma atenção redobrada. Para que as organizações possam cumprir sua missão e atingir os objetivos traçados em seu planejamento, precisam ter funcionários comprometidos com os mesmos. Assim fica evidente a importância de uma comunicação interna bem estruturada e transparente. Neste sentido a importância para as organizações de possuírem estratégias alinhadas de comunicação interna com o seu planejamento geral.

De acordo com Oliveira (2002, p. 97-8),

A dimensão estratégica acontece no momento em que os espaços de mediação, negociação, interação e diálogo são abertos, deixando no passado o caráter instrumental e mecânico de comunicação organizacional. O mais importante, agora, não é o emissor, a mensagem ou o meio, mas os receptores, entendidos como interlocutores. Nessa direção, é necessário entender os códigos culturais da organização, o que os interlocutores sentem e percebem em relação à organização, para conectar as demandas e promover discussão a partir da negociação. Esta possibilita encontrar o caminho do entendimento e aceitação das diferenças, a partir de um consenso, na busca de um interesse comum, se isso não acontece, não há, efetivamente, comunicação. A abertura 
da organização para o diálogo com os interlocutores, a confiança, o conhecimento e a transparência são as exigências para as organizações se posicionarem e se manterem competitivas no contexto contemporâneo.

Na perspectiva instrumental, a comunicação pode ser considerada como um pacote de ações padronizadas utilizadas em qualquer contexto, independente da dinâmica em que atua, uma cópia de ações aplicadas em outras realidades e, ainda, um sistema comunicacional genérico para qualquer situação. Segundo Reis (2004), nesse caso, a configuração própria da organização, com sua cultura que é única não é considerada.

A comunicação organizacional instrumental centra-se em passar e receber informação, reduzindo-se à mera transmissão de informação, onde a interação é praticamente nula. Esse tipo de comunicação centra-se na passividade das pessoas. A comunicação organizacional transmissora de informação valoriza os meios como jornais, por exemplo. Uma organização que preconiza esse tipo de comunicação não possibilita a existência de uma comunicação participativa ou efetiva, muito menos interativa. A comunicação só se efetiva quando existe entendimento entre as partes envolvidas (DEETZ apud MISHRA, 2007).

Para o processo comunicacional ser estratégico é necessário que ele oportunize uma mudança, um novo comportamento e não simplesmente informe sobre acontecimentos da organização. Entende-se que mudança e novo comportamento decorrem de uma comunicação dialógica calcada na interação, que permite confrontos em busca do consenso. Esta interação é permeada pelos valores da cultura da organização ao mesmo tempo em que oportuniza a construção de significados. A cultura e a comunicação organizacional atuam nas raízes de uma organização e posicionam a área de comunicação de uma forma estratégica (MARCHIORI, 2006).

O planejamento estratégico de comunicação também incorpora fortemente, a partir dos anos de 1990, as metodologias de administração japonesa. No Brasil, as grandes organizações procuram se ajustar, desde 1991, aos critérios da excelência e de avaliação do modelo de gestão da qualidade proposto pela Fundação para o Prêmio Nacional da Qualidade (FPNQ, 2001). Dentro dos oito critérios de excelência proposto pela FPNQ encontram-se os indicadores que 
balizam as gestões dos relacionamentos com os clientes, empregados e fornecedores e também as gestões das informações e conhecimento organizacional.

Embora seja crescente o número de organizações no Brasil e no mundo que mantêm um processo de comunicação contínuo e consolidado, o avanço da comunicação estratégica não é homogêneo nem linear, ocorrendo em estágios diferentes. Muitas atuam de forma instrumental e pontual, como decorrência de visões ainda restritas das organizações sobre o papel do campo da comunicação na contemporaneidade e do conhecimento e competência inadequados dos profissionais da área e da própria condição das estruturas de mercado em que as organizações atuam (ABERJE, 2005).

Nas organizações que tentam acompanhar as transformações do cenário onde atuam, a comunicação é entendida como estratégica. Portanto, as formas de gestão incentivam a participação dos públicos no processo de gestão e de tomada de decisões, buscam a criação, disseminação e compartilhamento da informação e conhecimento, exploram o imediatismo, interatividade e simultaneidade das novas tecnologias, visando a eficácia da comunicação. Mudam-se, assim, os objetivos, o conteúdo e a forma de fazer comunicação organizacional. A presença das novas tecnologias exige mudanças nas formas de acesso e de apresentação dos conteúdos que tentam acompanhar o ritmo das características da nova sociedade. A comunicação perde o seu caráter instrumental, de algo que pode ser transferido e usado para a realização das tarefas e motivação para a produtividade e torna-se estratégica, pautada na participação e geração de resultados.

Para atuar com complexidade e de acordo com as demandas daí decorrentes, as organizações são levadas a uma revisão de estruturas, conduta, políticas e estratégias, bem como da forma como concebem e gerenciam seus processos comunicacionais. Como decorrência, o campo de comunicação organizacional passa também por transformações. Uma das mais significativas refere-se a uma abordagem integrada do processo comunicacional, que supera um patamar técnico-instrumental, respaldada em planejamento e monitoria sistemática. Nessa perspectiva, a comunicação organizacional passa a ser considerada na implementação de ações de comunicação organizacional contemporânea, numa perspectiva integrada e estratégica, fundamentada na transparência, nas relações democráticas de geração de resultados para a organização. De acordo com Kunsch (2006b, p. 39), 
Pensar estrategicamente a comunicação organizacional pressupõe: revisão e avaliação dos paradigmas organizacionais vigentes e da comunicação; reconhecimento e auditoria da cultura organizacional e identificação e avaliação da importância do capital intelectual integral das organizações, que nem sempre é levado em conta.

É importante compreender a referência ao termo gestão estratégica da comunicação organizacional, a partir do alinhamento do processo com os objetivos e estratégias de negócio, destacando sua contribuição para o alcance dos resultados organizacionais e em relação à consideração da perspectiva dos atores sociais nas decisões organizacionais.

\subsection{1 - Componentes que conferem dimensão estratégica à comunicação}

Com o intuito de aprofundar aspectos teórico-conceituais e práticos que conferem dimensão estratégica à comunicação organizacional na atualidade, Oliveira e Paula (2006), apresentaram cinco componentes determinantes para conferir a dimensão estratégica à comunicação organizacional. São eles: (i) Tratamento processual da comunicação; (ii) Inserção na cadeia decisória; (iii) Gestão dos relacionamentos com atores sociais; (iv) Uso sistemático de planejamento; e (v) Monitoramento de desempenho e da contribuição para os resultados organizacionais.

O tratamento processual da comunicação diz respeito ao processo numa visão ampla e integrada das ações de todos os campos da comunicação e também à gestão organizacional e outras áreas da organização, de modo a apoiar diretamente políticas e estratégias de negócios e a contribuir para o alcance dos seus objetivos estratégicos bem como para a construção de sentido no ambiente interno e externo. Isso requer combinação e articulação dos fluxos informacionais e relacionais que materializam o processo comunicacional.

A inserção na cadeia decisória leva à sinalização de situações e cenários que afetam os atores sociais e à adoção de mecanismos que considerem a perspectiva desses atores sociais nas decisões. A partir daí é possível dimensionar o que os afeta e reorientar a abordagem para propiciar construção de sentido.

Na gestão dos relacionamentos com os atores sociais, o tratamento da comunicação enfatiza os fluxos informacionais, apoiados em meios de informação e relacionais por meio de 
oportunidades de diálogo da organização com seus atores sociais para dar conta da complexidade dos processos comunicacionais e favorecer sua gestão estratégica no campo das organizações.

O uso sistemático de planejamento fundamenta-se em metodologias de planejamento na comunicação organizacional voltadas para apoiar a visão de futuro das organizações. Somente por meio do planejamento e do entendimento da perspectiva dos atores sociais haverá o alinhamento e apoio efetivo da comunicação aos objetivos e estratégias organizacionais. É necessário que o planejamento do processo esteja respaldado pelo planejamento estratégico da organização, por levantamento de demandas das diferentes áreas internas e por pesquisas de opinião e de percepção dos atores sociais, para atender às diferentes demandas. $\mathrm{O}$ envolvimento dos profissionais de comunicação e de outras áreas da organização na elaboração das estratégias comunicacionais é indispensável para contemplar a diversidade de visões e experiências, variáveis do ambiente da organização e perspectivas dos atores sociais.

\section{O monitoramento de desempenho e da contribuição para os resultados} organizacionais requer metodologias e instrumentos específicos para que a organização identifique e avalie, de forma sistemática e periódica, expectativas e demandas dos atores sociais e a influência que exercem na sua atuação. O monitoramento diz respeito aos impactos e resultados do processo comunicacional, fazendo comparações entre uma situação inicial e posterior, gerenciando o processo de construção de sentido, a partir de avaliação e mensuração do grau de conhecimento e de entendimento dos atores sociais envolvidos. Refere-se, ainda, à contribuição da comunicação para o alcance dos objetivos organizacionais, por meio da estruturação de indicadores de desempenho alinhados aos objetivos estratégicos da organização e ao uso de pesquisas qualitativa e quantitativa, com periodicidade estabelecida e suporte metodológico.

O conjunto dos cinco componentes possibilita a proposição de políticas de comunicação que orientam as decisões e diretrizes da organização. Para Muriel e Rota (1980) uma política de comunicação explicita e sistematiza o conjunto de princípios e diretrizes que fundamentam o processo, assegurando sua coerência e articulação. Kunsch argumenta também que "definir uma política global de comunicação é algo fundamental, pois é ela que deverá direcionar toda a comunicação da organização" (KUNSCH, 2003, p. 273). Para viabilizar todo um planejamento 
estratégico de comunicação organizacional, a autora propõe princípios que devem ser levados em conta, a saber:

* A organização deve ter a consciência da importância de fazer o planejamento estratégico como uma metodologia gerencial ou técnica administrativa capaz de direcionar suas atividades com vistas em resultados eficazes que correspondam às demandas e às necessidades do ambiente. E que ele realmente seja utilizado em determinados períodos, para redimensionar a organização como um todo. Se não existir uma cultura de valorização do planejamento estratégico para provocar mudanças e vontade política no sentido de redefinir a organização no seu conjunto, não adianta querer fazer um plano estratégico de comunicação isoladamente;

* A área de comunicação precisa ocupar um espaço estratégico na estrutura organizacional. Isto é, deve estar subordinada à cúpula diretiva e participar de gestão estratégica. Pois, se for apenas uma área de apoio para atender às necessidades de comunicação, executando tarefas e produzindo veículos comunicacionais, dificilmente conseguirá planejar, pensar e administrar estrategicamente a comunicação numa perspectiva macro, empreendedora e em consonância com a missão, a visão e os valores organizacionais;

* Capacitação do executivo principal, responsável pela comunicação e da equipe que conduzirá o processo. Estes precisam estar preparados e deter conhecimentos técnicocientíficos sobre planejamento estratégico, sobre os campos das ciências da comunicação;

* A valorização de uma cultura organizacional corporativa, em que se crie possibilidade efetiva de participação das pessoas, envolvendo-as no processo de formulação do planejamento estratégico, dando-lhes oportunidade de criar, pensar estrategicamente, equacionar as causas dos pontos fracos e fortes do ambiente interno e da comunicação organizacional integrada, constitui também um princípio relevante que necessita ser levado em consideração pelas organizações modernas. 
Seguindo a mesma linha, contemplando alguns pontos indicados por Oliveira e Paula (2006) e Kunsch (2003) e acrescentando outros, Meade (2010) propõe alguns passos que as empresas devem seguir para um planejamento estratégico da comunicação interna, entre eles:

* Avaliação da cultura comunicacional existente: aqui é avaliado o status da cultura comunicacional, ou seja, se ela é forte ou fraca. Uma cultura comunicacional forte possibilita a existência de vários canais de comunicação para manter os empregados informados não só em relação às atividades da empresa e sim também em relação às performances de cada um.

* Rever a história e recursos: nesta etapa devem ser identificadas as mudanças que ocorreram nas lideranças bem como se eles vão passar por uma fusão ou aquisição. $\mathrm{O}$ objetivo desta etapa é proporcionar um bom entendimento da cultura comunicacional existente, compreender algumas das principais diferenças em como os empregados da empresa preferem se comunicar ajudará a definir a cultura da comunicação que reduza desentendimentos e conflitos.

Definir a cultura comunicacional desejado: aqui o objetivo é identificar o tipo de cultura de comunicação interna que pode viabilizar a empresa de alcançar de melhor forma sua missão e objetivos organizacionais. Algumas são as características centrais para tal cultura: uma forte comunicação interna é caracterizado por confiança; valorização dos membros da empresa; uso de canais formais para manter seus membros informados e envolvidos.

* Esboçar táticas de comunicação: segundo a autora esta etapa pode ser a mais difícil porque requer a construção de uma ponte entre cultura comunicacional existente e a desejada. A construção dessa ponte começa por criação de uma matriz da comunicação interna da organização com especificação de cada tipo de mensagem, canal e fluxo que deve ser utilizado.

* Fazer revisão e implementação: esta etapa deve considerar os recursos técnicos e humanos e que impactos podem sofrer com mudanças de táticas administrativas. Os prazos devem ser estabelecidos e reforçados pra que os empregados possam priorizar suas 
revisões e providenciar na hora certa o feedback. Após o recebimemto do feedback, o plano deve ser avaliado nos seguintes aspectos: deve sustentar uma melhoria do plano estratégico como um todo; deve ser consistente com as mensagens-chave e a cultura da comunicação interna desejada; deve ser viável dentro do escopo dos recursos financeiros, técnicos, institucional e humano

* Monitorar, avaliar e atualizar: a comunicação interna é um processo por isso precisa ser constantemente monitorado, avaliado e atualizado de acordo com as necessidades.

Ainda segundo Meade (2010) para desenvolver e implementar uma comunicação interna estratégica é necessário a criação de uma cultura de comunicação interna que dá poder aos empregados para entregar tipos de experiências que se destacam das concorrências. A autora defende que para criar uma cultura de comunicação interna eficaz faz-se necessário uma estratégia de comunicação que encoraja tipos de comportamentos necessários para o sucesso organizacional a longo prazo.

Nota-se que o planejamento estratégico tornou-se muito importante nos dias de hoje para uma organização que quer se manter competitiva no mercado exigente, mutável e turbulento. Este ambiente em contínua agitação redimensiona o perfil das organizações e as torna menos estratificadas, mais flexíveis, convidando-as permanentemente a prever e enxergar o futuro. Nesse contexto, de acordo com Kunsch (2003), buscar a eficácia na comunicação deve ser a principal meta das organizações modernas. E isso será possível com o planejamento estratégico, com a valorização do processo de gestão participativa na comunicação organizacional e com o uso da comunicação harmônica entre a fonte e os receptores.

A partir da década de 1980, o conceito de comunicação organizacional passou a vincularse ao negócio da organização. Deixava de ser, de acordo com Bueno (2003) um mero conjunto de atividades desenvolvidas de maneira fragmentada para constituir-se em um processo integrado que orienta o relacionamento da organização com todos os seus públicos de interesse, consolidando-se a perspectiva estratégica da comunicação.

Evidentemente, o sistema de planejamento tradicional, de longo prazo, feito simplesmente por planejadores estratégicos, profissionais externos, sem vinculação com quem o executa já não 
funciona mais, pois tende a ver as coisas de forma fragmentada, buscando estabelecer padrões que se acomodam aos modelos anteriormente conhecidos (KUNSCH, 2003).

Faz-se necessário que a comunicação organizacional se constitua em um setor estratégico, onde valores são agregados e os processos interativos e as mediações da organização com seus diferentes públicos são facilitados. Assim, Kunsch (2003) define a importância da comunicação como ferramenta estratégica capaz de fazer uma análise do ambiente interno e externo da organização, indicando ameaças e oportunidades. Para tal, é imperioso a idéia de comunicação integrada, onde a comunicação organizacional compreenderá um conceito amplo das diferentes modalidades comunicacionais que ocorrem dentro da organização. São elas: as comunicações institucional, interna, administrativa e de marketing.

Oliveira (2002, p. 66) destaca que “o resultado final do processo de controle é a informação". Assim, os executivos devem procurar estabelecer, durante a execução do planejamento estratégico, um sistema de informações que permite avaliar, constantemente, os objetivos, metas, estratégias e projetos da organização. Esse sistema, para conseguir dados relevantes e condizentes com a realidade organizacional, deverá ser desenvolvido com informações provenientes de todos os departamentos e setores.

De acordo com Rego (2002) cada vez mais a comunicação ganha status de consultoria estratégica, que se desenvolve por meio de funções e orientações de leitura de ambiente, de interpretação de cenários e de assessoria aos sistemas decisórios, principalmente em momentos de crise.

Ulrich (2003) afirma que diante da necessidade de desenvolver capacidades organizacionais como rigidez, capacidade de reação, agilidade, capacidade de aprendizagem e competência dos funcionários, as organizações bem sucedidas serão aquelas capazes de transformar estratégia em ação rapidamente, de gerenciar processos de maneira inteligente e eficiente, de maximizar o compromisso e a colaboração do funcionário.

A implantação de sistemas de comunicação em organizações exige um minucioso planejamento, adequado à multiplicidade dos atos comunicativos, permitindo assim que toda a 
organização persegue um equilíbrio entre os diversos setores que a formam. Integração será alcançada por meio de um processo comunicacional.

Cabe ressaltar que além do planejamento estratégico a organização também deverá possuir planejamentos nos níveis tático e operacional. O planejamento organizacional pode ser definido como um conjunto de atividades de planejamento que se estendem a todos os níveis de organização. Como afirmam Armstrong e Kotler (2000, p. 21) "o planejamento estratégico estabelece a base para o resto do planejamento de uma empresa". Ele é o processo que ocorre no nível estratégico da estrutura organizacional e deve nortear as atividades de planejamento nos demais níveis hierárquicos.

Segundo Kunsch (2003) hoje é necessário um planejamento estratégico e outros tipos de planejamentos que envolvam todas as áreas da organização, inclusive a da comunicação, a fim de direcionar os seus rumos e contribuir para a sobrevivência e competitividade. Assim é importante que se trabalhe com um planejamento global de comunicação que estabeleça ações conjuntas e que contribuam para que as atividades desenvolvidas pelas diferentes áreas sejam somadas em benefício da organização. O planejamento de comunicação, classificado como planejamento tático, deve fundamentar-se no planejamento estratégico organizacional.

Corroborando a idéia de Kunsch (2003), Costa (1995, p. 30) realça a necessidade do planejamento de comunicação no planejamento estratégico da organização. Para o autor a comunicação possui dois sentidos: como modo de relação entre os empregados e a organização e como instrumento estratégico. A ação é comunicação e comunicar implica em atuar, podendo ser ela considerada como uma questão estratégica para a tomada de decisões e para a ação corporativa.

De repente aquello que antes parecia um subproduto de la actividad empresarial porque el negocio se obtenía com el produto -, ahora se há revelado com toda claridad como instrumento estratégico y operacional de primer orden: la comunicación, y muy especialmente la comunicación corporativa, em el sentido holista que yo doy.

Na mesma linha, Albuquerque (2002, p. 41) argumenta que a estratégia das outras áreas deve seguir as etapas do processo de formulação da estratégia corporativa, baseando-se na visão do negócio para desenvolver as diversas etapas da estratégia funcional que irão integrar a 
estratégia da organização, ou seja, a estratégia das outras áreas funcionais deve estar integrada à estratégia da organização. O autor (op. cit., p. 47) ainda ressalta que:

No processo integrado e participativo da formulação e implementação estratégica (...) os limites entre a formulação e a implementação perdem o sentido, o feedback de informações é contínuo em todas as etapas e os resultados mais importantes são a participação e seu comprometimento com os intentos da organização e as formas a serem adotadas para realizá-los.

Bueno (2005) afirma que a comunicação integrada significa que as atividades de comunicação se integram ao processo de gestão, de planejamento, de marketing e que obedecem à política e diretrizes comuns.

Corroborando, Lupetti (2000) assevera que do planejamento global da organização, elaborado no nível estratégico, nascem os planejamentos táticos que precisam, necessariamente, ser acordados e coordenados com o planejamento global da organização. Dos planejamentos táticos, exemplificando, planejamento de $\mathrm{RH}$, nascem os planejamentos operacionais, como, por exemplo, o planejamento de comunicação. Todos os planejamentos táticos e operacionais estão interligados ao planejamento global, o que Albuquerque por sua vez chama de planejamento corporativo.

Tanto Kunsch, Bueno, Albuquerque, Costa, Armstrong e Kotler e Lupetti apontam a importância do planejamento organizacional, existência de planejamentos funcionais, mas ressalvam que todos os planejamentos funcionais devem levar em consideração a estratégia corporativa, ou seja, devem sempre ter em vista a visão do negócio da organização.

As organizações de hoje para se posicionarem no mercado e fazer face aos desafios da complexidade contemporânea precisam planejar, administrar e pensar estrategicamente a sua comunicação.

De acordo com Kunsch (2003) não basta pautar-se por ações isoladas de comunicação, centradas no planejamento tático, para resolver questões, gerenciar crises e gerir veículos 
comunicacionais sem uma conexão com a análise ambiental e as necessidades do público, de forma permanente e estrategicamente pensada.

É importante entender a importância da análise do público, por meio de pesquisas, auditoria, levantamento da cultura organizacional, conhecimento do negócio, avaliação dos pontos fortes e fracos, ameaças e oportunidades, aspectos fundamentais na elaboração de um planejamento estratégico de comunicação interna. Isso torna-se efetivo graças a uma administração estratégica, ou seja, a organização necessita valorizar este processo e perceber os resultados que traz quando tem prática da comunicação profissionalizada.

A implantação do modelo de comunicação deve ser calcada na cultura organizacional da instituição para que se possa obter eficácia, pois esse modelo direcionará a emissão de mensagens adequadas, corretas, oportunas, claras, precisas e concisas, que possam ser assimiladas sem ruídos pelas pessoas que fazem parte da instituição. Para que isso ocorra a organização deve ajustar seu discurso, procurando estudar com cuidado as habilidades e a disposição das fontes e receptores, a natureza dos canais, a complexidade/ simplicidade dos conteúdos e a oportunidade e regularidade dos fluxos.

Assim sendo, a comunicação estratégica é aquela que está junto ao poder decisório, com direito a participar do planejamento estratégico, que é parte da cultura organizacional, estimula nos interlocutores o desempenho simultâneo do papel de emissor e receptor, gera interação por meio do diálogo e direciona os fluxos informacionais para o negócio da organização.

\section{3 - Comunicação interna integrada}

Vários outros termos, como endomarketing, marketing para dentro e marketing interno, são usados para descrever a comunicação entre a organização e o funcionário. Neste trabalho, adotaremos o termo comunicação interna.

Para que o público interno torne-se aliado da organização, esta deve estabelecer uma comunicação constante com seus funcionários, compartilhando com estes sua missão, visão, 
valores e objetivos e informando-lhes sobre todas as mudanças ocorridas. As pessoas também precisam sentir que são necessárias e que seu trabalho é fundamental para a consecução dos objetivos organizacionais.

Brum (2000, p. 149) assevera que:

\begin{abstract}
A partir do momento em que o funcionário passa a conhecer verdadeiramente a empresa na qual trabalha e o que pensa a Direção, sente-se desempenhando um papel determinante para a manutenção e o crescimento dessa empresa. O sentir-se importante passa pelo grau de informação que recebe, já que na comunicação interna este é o produto da troca.
\end{abstract}

No entanto, a informação não deve ser transmitida apenas no sentido vertical, de cima para baixo. Para produzir mais e melhor, a organização também precisa da opinião e da participação dos seus funcionários. Uma comunicação de duas vias, que informa os funcionários sobre as decisões da organização e, ao mesmo tempo, estimula a participação destes, faz com que os mesmos sintam-se co-responsáveis pelo sucesso da organização. Ao estabelecer um processo de troca de informações, a organização pode obter o envolvimento e comprometimento do funcionário com os objetivos organizacionais.

A comunicação interna, por sua vez, pode ocorrer de duas maneiras: por meio do acesso formal ou informal à informação (LIMONGI-FRANÇA, 2007). Em muitas organizações, devido à falta de estrutura e de um departamento profissionalizado, o acesso à informação ocorre de maneira informal. Isso, certamente, pode prejudicar a integração da Direção com os funcionários e, conseqüentemente, pode acabar gerando o descomprometimento do público interno com os objetivos e estratégias organizacionais.

É notável que toda a mudança que vem ocorrendo no contrato de trabalho e o excesso de imprevisibilidade nas organizações afetam o ambiente organizacional interno. O novo cenário remete-nos para o seguinte questionamento: qual o novo papel da comunicação organizacional interna? 
Verifica-se que o estudo de comunicação organizacional em geral e da interna em particular tem-se aperfeiçoado muito nas últimas décadas. Contudo, há muito que fazer na maioria das organizações senão em todas para aproximar o discurso da prática ou pelo menos minimizar as contradições.

Muito se fala na necessidade de valorizar os empregados, integrá-los mais ao ambiente da organização, abrir espaço para criação e revelação de talentos, necessidade de se conferir maior autonomia, empowerment, tornar cada empregado colaborador/ parceiro estratégico do negócio, importância sobre a disseminação da visão, missão, objetivos organizacionais, dar espaço para que os empregados, junto com a organização, tracem objetivos e estratégias para o alcance do sucesso e de que tão importante quanto o resultado é a forma como ele foi alcançado. Nesse cenário, faz-se necessário desenvolver e melhorar habilidades de comunicação de cada colaborador, capacitando-o para atuação com maior competência e responsabilidade sobre o seu novo papel na organização.

No entanto, apesar do esforço empreendido por algumas organizações, ainda vigora um modelo de comunicação em consonância com o modelo que privilegia a burocracia na produção de mensagens e notícias, a hierarquia para o acesso à informação e à apresentação de idéias que ainda trata as pessoas como recursos descartáveis em momentos de crise, que muitas vezes considera de mais relevância a apresentação de resultados para o acionista a qualquer preço.

Apesar dos mais variados recursos de informação atualmente disponíveis e a retórica dos dirigentes sobre a importância da comunicação com todos os seus públicos, existe no caso do público interno um contingente significativo de empregados que sequer sabem aonde suas organizações pretendem chegar (ABERJE, 2001).

A comunicação interna plena, tal e qual se defende hoje, não tem lugar num ambiente no qual os empregados são pagos para executar ordens em vez de pensar. Nesse ambiente, a comunicação tende a ser vertical, de cima para baixo, dificultada e essencialmente instrumental. Chanlat (1994) ressalta para o perigo dessa prática, asseverando que: a comunicação em uma organização não pode ser reduzida ao mero processo de transmissão de informações, sob pena de perder todo o seu sentido e significação. 
Nesse aspecto, todos os instrumentos de análise entre negócio, estrutura, estratégias, políticas e pessoas, bem como as intervenções sobre processos interpessoais que possam favorecer a flexibilidade comportamental fazem a diferença para o sucesso da organização. A comunicação, principalmente a interna, nesse caso, ganha relevo e destaque. Deixa de ser mero fetiche para contribuir, efetivamente, para a eficiência e a eficácia organizacionais (KUNCSH, 2003, p. 158).

De acordo com Mishra (2007) é esperado que uma comunicação interna eficaz que flui entre empregados e a direção traga confiança entre essas duas partes, permitindo assim a construção de um verdadeiro relacionamento entre empregados e a organização. No entanto, ressaltam Gavin e Mayer apud Mishra (2007) que essa comunicação deve ser aberta e honesta.

Diante desses desafios, fornecer informações, dar às pessoas suporte para a expressão de seus sentimentos, envolvê-las no planejamento e implementação das estratégias, habilitar gestores e empregados como comunicadores e fornecer feedback, retroalimentando o processo de comunicação organizacional interna, são ações que devem fazer parte do cotidiano das organizações. É preciso lançar novas bases para um relacionamento mais produtivo e eficaz do público interno, com intuito de obter um desenvolvimento organizacional mais competitivo e alinhado com os anseios do mercado competitivo. É oportuno ajudar as organizações a dar sentido a seu discurso organizacional de que as pessoas são o diferencial competitivo da organização.

A comunicação interna vista como comunicação integrada, com políticas globais estabelecidas, estratégias delineadas e programas de ação voltados para todo o pessoal do ambiente interno, tenderá a ser muito mais eficiente e eficaz (KUNSCH, 1997).

Portanto, entendemos que "é a comunicação que ocorre na organização e é a comunicação entre ela e o seu meio ambiente que a definem e determinam suas condições de existência e a direção de seu movimento" (THAYER, 1972, p. 120); "que as comunicações são tão essenciais para uma organização que, se pudéssemos identificar todos os canais que transmitem informações e os meios pelos quais a informação influencia o comportamento da organização, estaríamos mais próximos de compreender a organização em si” (LITTERER, 1977, p. 58); “que a comunicação é 
imprescindível para a sobrevivência da organização, pois o sistema organizacional se viabiliza graças ao sistema de comunicação nele existente" (KUNSCH, 2003, p. 69).

Thayer (1972, p. 76) aponta dois aspectos básicos sobre a questão da comunicação nas organizações:

\begin{abstract}
Quando se organiza uma empresa coletiva, de qualquer tipo, o que se organiza, de fato, é o fluxo de informações relacionadas com a empresa e, em decorrência, as relações estratégicas entre as partes funcionais; deveria ser absolutamente óbvio para quem está 'fazendo comunicação' preocupar-se em considerar como o receptor está recebendo a comunicação, como única forma para obtenção da eficácia desejada.
\end{abstract}

Partindo dessas reflexões, torna-se evidente a importância singular da comunicação nas organizações, sejam elas públicas, privadas ou ONG's.

Corrado (1994), na mesma linha, propõe algumas reflexões sobre a questão comunicação. São elas:

* Pode uma organização ter uma boa imagem se não gozar de uma boa imagem junto aos seus funcionários?

* Se um funcionário não for bem-informado e nem leal, e, por conta disso, não tiver uma boa imagem da organização, que impacto isso pode trazer para os resultados globais da organização?

* A direção da organização é capaz de dar aos funcionários a ampla gama de informações requeridas por eles?

* É possível ter um programa eficaz de qualidade sem uma comunicação interna adequada? Dentro dessa perspectiva, uma parte desses questionamentos pode ser atribuída à necessidade de maior participação dos funcionários nos processos decisórios da organização. Ainda de acordo com o autor (1994, p. 49), pesquisas realizadas nos últimos anos sinalizam que funcionários têm anseios por comunicações muito simples. "Desejam saber quais são os problemas, como a organização lidará com eles e qual o seu papel como funcionário [...] $\mathrm{Na}$ 
ausência de uma comunicação digna de crédito, os boatos preenchem o hiato" (CORRADO, op. cit., p. 48).

Por conseguinte, hoje, mais do que nunca a relação organização-funcionário deve ser tratada acima de tudo como uma relação de compromisso e respeito.

Na concepção de Bowditch e Buono (1992, p. 80) "um dos processos fundamentais, que constituiu a base para quase todas as atividades nas organizações é a comunicação”. Kreeps (1995, p. 27) ao destacar a importância da comunicação para as organizações, explana o lado frágil da natureza da comunicação humana, que por sua complexidade, sutilezas e singularidades, sempre pode provocar, ao contrário do que se propõe, incompreensão, mal entendidos e ou discordâncias entre os interlocutores. Talvez um dos maiores problemas da comunicação humana na vida organizacional seja a presunção de que seja fácil comunicar-se corretamente (THAYER, 1972). Assim, como ressalta Piñuel Raigada (1997, p. 94), "servir-se de uma política de comunicação interna é comprometer-se a desenvolver relações de trabalho que não apenas considerem a atuação sobre a compreensão ou inteligibilidade da própria organização, mas também sobre seu próprio desenvolvimento".

\subsection{1 - Importância da comunicação interna versus participação dos empregados}

A elaboração de qualquer plano de comunicação, que inclua o delineamento de uma política, passa necessariamente pelo tratamento de aspectos como a subjetividade da produção informativa, as singularidades presentes nos processos, os filtros, as barreiras de comunicação (físicas, mecânicas, psicológicas, sociais, lingüísticas, etc.).

Não basta dizer que o público interno é estratégico para a organização, se a abordagem não apresenta temas estratégicos de relevância ao empregado; ou enfatizar que o público interno deve ser priorizado nos processos de comunicação se no dia-a-dia a comunicação chega simultaneamente para todos os stakeholders da organização da mesma forma sem levar em consideração a diferença dos públicos; que se trata de um público que merece uma ação planejada de comunicação, capaz de atender aos seus anseios e necessidades de informação sobre a organização, quando a comunicação organizacional se resume à publicação de notícias frias nos veículos internos; que o público interno deve ser tratado como multiplicador das boas e más 
ações da organização, se o empregado sequer tem informação mínima para o adequado desempenho de suas funções; ou que é um público capaz de gerar resultados palpáveis, se não é consultado nem opina sobre a maioria das decisões estratégicas tomadas pela organização, que tem a ver com o seu trabalho.

A importância da comunicação interna reside nas possibilidades que ela oferece de estímulo ao diálogo e à troca de informações e, especialmente, ao desenvolvimento consistente e sustentado das pessoas e da organização (KUNSCH, 2003, p. 159). Portanto, é necessário considerar as diferenças de necessidades de informação requeridas por cada segmento do público interno, a exemplo do público externo, visto de maneira holística e tratado de maneira cada vez mais personalizada.

Hermosa (1990, p. 83) assevera que o principal objetivo de qualquer programa de comunicação interna passa, necessariamente, pelo estreitamento dos laços entre a direção e os empregados, pela redução dos antagonismos entre os empregados e grupos, pela busca da obtenção da sinergia, pela busca da criação de cultura comum e um sistema de valores reconhecido e compartilhado para a construção da identidade organizacional coerente e verdadeira.

Para Rodríguez de San Miguel (1996, p. 32) a comunicação interna é uma parte da comunicação organizacional ao asseverar que:

Comunicação interna é um conjunto de atividades efetuadas por qualquer organização para criação e manutenção de boas relações com e entre seus membros, através do uso de diferentes meios de comunicação que os mantenham informados, integrados e motivados para contribuir com seu trabalho para que se alcancem os objetivos organizacionais.

O autor divide a comunicação organizacional em comunicação interna e externa, realçando a 'manutenção de boas relações com e entre os membros', o que Goodall Jr e Eisenberg (1997) chamam de comunicação com os subordinados'. Rodriguez de San Miguel (op.cit.) ressalta que a organização deve manter os funcionários informados, integrados e motivados com o intuito de contribuir melhor para o alcance dos objetivos da organização. $\mathrm{O}$ autor ainda enfatiza que os interesses da organização orientam, em grande parte, as ações da comunicação interna. 
Nota-se que a comunicação com os colaboradores ganha destaque, hoje, com a crescente valorização do capital intelectual. Piñuel Raigada (1997, p. 98) enfatiza isso ao assegurar que:

\begin{abstract}
A informação e a comunicação interna encontram-se intimamente ligadas entre si. De um lado, compartilham o mesmo campo de aplicação e mesmo objetivo geral: adaptar a empresa às exigências atuais e futuras da mudança, transmitindo um mesmo discurso argumentativo (...). Por outro lado, os esforços de comunicação estão nos pequenos procedimentos acompanhados de operações de comunicação interna, para sensibilizar o consentimento pessoal a fim de promover o consenso, explicando seus motivos, o de fazer compreensível e inteligível seus objetivos, integrando-os numa lógica global da organização (...). Seria aberrante difundir mensagens entre o seu pessoal sem levar em conta quais são suas representações.
\end{abstract}

Assim, a comunicação é um instrumento que liga a organização e seus colaboradores. De acordo com Kunsch (2003, p. 128) a comunicação interna é parte da comunicação integrada e deve ser pensada estrategicamente:

A comunicação interna deve viabilizar uma interação efetiva entre a organização e seus empregados, usando ferramentas da comunicação institucional e até da comunicação mercadológica (endomarketing e marketing) (...) Ela será fruto de um trabalho pensado, organizado e constantemente avaliado, não ocorrendo simplesmente de forma casuística na vida da organização. (...) A comunicação interna deve contribuir para o exercício da cidadania e para a valorização do homem.

Tanto Kunsch como Piñuel Raigada usam o termo comunicação interna para descrever uma comunicação elaborada e planejada com o público interno. Isso fica evidente quando Raigada afirma que a comunicação interna e formação estão intimamente relacionadas, concordando com o que Kunsch (2003, p. 128) descreve acerca da comunicação interna:

A comunicação interna deve contribuir para o exercício da cidadania e para a valorização do homem. Quantos valores poderão ser descobertos e acentuados mediante uma atividade comunicacional participativa! A oportunidade de se manifestar e de se comunicar livremente canalizará energias para fins construtivos, tanto do ponto de vista pessoal quanto profissional (...) E um serviço de comunicação tem muito a ver com isso, uma vez que, agilizando o processo comunicativo, promove a integração entre diferentes setores (...) A comunicação interna permitirá que ele seja bem informado e que a organização antecipe respostas para suas expectativas. Isso ajudará a administrar conflitos e a buscar soluções preventivas.

Piñuel Raigada (1997) afirma que a comunicação é responsável por sensibilizar o público interno e promover consenso, integrando-o à organização. 
A comunicação interna ganha dimensões complexas e mais abrangentes no conjunto das ações de comunicação nas organizações. Promover o consenso é tarefa difícil, pois as pessoas têm expectativas diferentes. Contudo, promover consenso quanto aos objetivos organizacionais como um todo é necessário para que todos caminhem numa mesma direção. A comunicação interna é fundamental aqui, pois favorece a troca de informações e ajuda para que a organização conheça os interesses dos que trabalham nela.

Em decorrência, a estratégia de negócio não pode estar dissociada da estratégia de pessoas. É preciso construir relacionamentos e para isso é necessário que haja comunicação aberta, intensa e transparente. É preciso criar vínculos com a organização, é fundamental entender a cultura da organização e saber de que forma construir discursos, em que momento evidenciar e criar relações que possam gerar ambientes nos quais, naturalmente, as pessoas são e sentem-se comprometidas.

A pesquisa sobre tendência em gestão de pessoas em empresas brasileiras (Fischer e Albuquerque, 2004) aponta que o maior desafio dos profissionais de $\mathrm{RH}$, visão de 82,3\% dos respondentes, é o de alinhar pessoas, seus respectivos desempenho e competências às estratégias do negócio e objetivos organizacionais, conseguido somente por meio de funcionários comprometidos com a organização. Portanto, embora não se possa afirmar ser estratégia suficiente, a criação de do comprometimento organizacional corresponde à condição necessária às organizações que pretendem obter vantagem competitiva sustentável, com base na gestão de pessoas, num mercado globalizado (CHANG JR; ALBUQUERQUE, 2002).

Segundo Dessler (1996) poucos argumentariam com o fato de que a forma mais poderosa de garantir a execução correta do trabalho da empresa é sincronizar as metas organizacionais com as de seus funcionários, garantindo, em outras palavras, que os dois conjuntos de metas sejam essencialmente os mesmos, de modo que ao procurar realizar as suas próprias metas, o funcionário procure realizar também as metas da empresa. Para o autor criar comprometimento é forjar tal síntese.

Fleury (1996, p.24) assevera que "a comunicação se constitui em um dos elementos essenciais no processo de criação, transmissão e cristalização do universo simbólico de uma organização". De acordo com a autora o mapeamento do sistema de comunicação, sistema esse 
pensado tanto como meios, instrumentos, veículos, quanto como a relação entre quem se comunica é fundamental para a apreensão desse universo simbólico.

Marchiori (2006) sugere algumas proposições para a qualidade do processo de comunicação interna: São elas:

* Políticas e estratégias definidas e transparentes;

* Diálogo aberto entre direção e funcionários;

- Busca de comprometimentos, por meio de veracidade nos relacionamentos;

* Seleção de informações que contribuam para o incremento do nível de conhecimento;

Adaptação de formato de discurso, que observem as linguagens capazes de causar impacto junto às diferentes categorias de funcionários;

* Utilização de múltiplos canais;

* Interatividade;

* Valorização das redes de liderança: formais e informais;

Mensuração e tomada de decisão para o novo planejamento.

A autora entende que uma organização comunica de forma perfeita quando seus funcionários se comunicam de maneira contínua, formal e informal entre os diversos níveis organizacionais e contam a mesma história da organização para seus diferentes públicos.

Verifica-se, que existe um consenso entre os pesquisadores do assunto de que a comunicação é imprescindível para o bom funcionamento das organizações, pois por meio dela é que se cria e se dissemina a cultura, objetivos e missão da organização.

Contudo, tudo depende do grau de coesão interna e de identificação dos empregados e gestores com os membros da direção e destes com os objetivos organizacionais. Assim, a comunicação interna poderá contribuir para valorizar o empregado como pessoa e cidadão; dar transparência aos fenômenos organizacionais; dar abertura ao diálogo; favorecer a gestão 
participativa e propiciar um clima de bem-estar. A comunicação em qualquer que seja a organização deve ser uma responsabilidade compartilhada.

O crescimento do estudo do comportamento humano a partir da influência da Escola de Relações Humanas, o surgimento de novas técnicas de gestão que privilegiam a qualidade total, o empowerment, entre outras, buscam ampliar a participação das pessoas na administração, o papel do empregado de executor para protagonista e a necessidade de entender o homem e seu comportamento nas organizações.

A partir da acepção de vários conceitos de comunicação apresentados pelos pesquisadores da área, entendemos, conceitualmente, que a comunicação interna é uma ação estratégica e integrada de comunicação com o público interno e para isso deve dispor de canais e instrumentos diversos que permitem as pessoas das várias áreas da organização atuarem sinergicamente. Esta comunicação não deve se reduzir à transmissão de informações, sem a preocupação de gerar o feedback para as pessoas envolvidas no processo. Este será o conceito de comunicação interna adotado para o desenvolvimento deste estudo.

A seguir, o quadro 2 com as principais abordagens teóricas sobre comunicação organizacional. 
Quadro n 2 - Principais abordagens teóricas de comunicação organizacional

\begin{tabular}{|c|c|}
\hline Perspectiva & $\begin{array}{l}\text { Descrição das características do planejamento da comunicação organizacional e } \\
\text { respectivos autores }\end{array}$ \\
\hline $\begin{array}{l}\text { Comunicação } \\
\text { organizacional }\end{array}$ & $\begin{array}{l}\text { A comunicação organizacional deve ser planejada, envolvendo todos os setores da } \\
\text { comunicação organizacional, quais sejam: comunicação de interna, administrativa, } \\
\text { mercadológica e instituicional. Deve haver uma convergência de todas as atividades com } \\
\text { base numa política global, claramente definida e nos objetivos gerais da organização } \\
\text { (Kunsch, 2003). Rego (2002) define comunicação organizacional como sendo a } \\
\text { possibilidade sistêmica que integra e reúne as modalidades de comunicação cultural, } \\
\text { administrativa e social. Goldhaber (1991) define comunicação organizacional como um } \\
\text { processo dinâmico por meio do qual as organizações de relacionam com o meio ambiente } \\
\text { e as subpartes se conectam entre si por um fluxo de mensagens processadas em uma rede } \\
\text { de relações interdependentes. Na mesma linha, autores como Daniels et al (1997); } \\
\text { Goodall Jr e Eisenberg (1997) identificam modelos de comunicação organizacional.Já } \\
\text { para Hall (1984) a comunicação é um processo relacional. Na mesma linha Restrepo e } \\
\text { Ângulo (1995) enfatizam que a comunicação nas organizações deve ser entendida de } \\
\text { forma integral, permeando todas as ações organizacionais. } \\
\text { Seguindo um outro enfoque encontra autores como Kreeps (1990) que entendem a } \\
\text { comunicação organizacional desempenha uma função de fonte de informação para os } \\
\text { membros da organização e aqui a comunicação se resume a mera transmissão de } \\
\text { informação, sem considerar a necessidade de interação. }\end{array}$ \\
\hline $\begin{array}{l}\text { Planejamento da } \\
\text { comunicação } \\
\text { organizacional }\end{array}$ & $\begin{array}{l}\text { Marchiori (2006) assevera que para que haja uma comunicação integrada que transmite } \\
\text { uma mensagem única, consistente e transparente ela precisa ser planejada. Para que ela } \\
\text { seja planejada é necessário que seja explicitado e sistematizado um conjunto de } \\
\text { princípios e diretrizes que fundamental o processo, assegurando sua coerência e } \\
\text { articulação conforme indicam Kunsch }(1997,2003,2006 b) \text {; Marchiori (2006); Oliveira e } \\
\text { Paula (2006); Meade (2010); Muriel e Rota (1980). Autores como Kunsch (2003); Bueno } \\
\text { (2005); Albuquerque (2002); Costa et al (1995); Lupetti (2000) apontam a importância } \\
\text { do planejamento organizacional, existência de planejamentos funcionais, mas ressalvam } \\
\text { que todos os planejamentos funcionais devem levar em consideração a estratégia } \\
\text { corporativa. Kunsch (2003) afirma que não basta pautar-se por ações isoladas de } \\
\text { comunicação centradas no planejamento tático, para resolver questões, gerenciar crises e } \\
\text { gerir veículos comunicacionais sem uma conexão com a análise ambiental e as } \\
\text { necessidades do público de forma permanente e estratégica pensada. } \\
\text { Oliveira (2002) realça que a perspectiva instrumental considera a comunicação como } \\
\text { sendo um pacote de ações padronizadas utilizadas em qualquer contexto, independente da } \\
\text { dinâmica em que atua. Essa perspectiva é criticada pela Marchiori (2006) que afirma que } \\
\text { para que o processo comunicacional seja estratégico ele precisa oportunizar uma } \\
\text { mudança, um novo comportamento e não um simples informe sobre acontecimentos da } \\
\text { organização. }\end{array}$ \\
\hline $\begin{array}{l}\text { Comunicação interna } \\
\text { integrada }\end{array}$ & $\begin{array}{l}\text { A comunicação interna vista como integrada, com políticas globais estabelecidas, } \\
\text { estratégias delineadas e programas de ação voltados para todo o pessoal do ambiente } \\
\text { interno, tende a ser mais eficiente e eficaz (Kunsch, 2003). Piñuel Raigada (1997) assim } \\
\text { como Kunsch (2003) usam o termo comunicação interna para descrever uma } \\
\text { comunicação elaborada e planejada com o público interno. Marchiori (2006) sugere } \\
\text { algumas proposições para a qualidade do processo de comunicação interna. Rego (2002) } \\
\text { assim como Kunsch (2003) destacam que o uso sinérgico da comunicação resultará na } \\
\text { maximização do processo de comunicação, resultando numa comunicação mais eficaz. } \\
\text { Segundo esses autores, o uso sinérgico da comunicação, envolvendo todos os } \\
\text { participantes da organização resultará em melhores condições do ato comunicativo, } \\
\text { clarificando os canais, estabelecendo sistemas eficientes de coordenação, gerando } \\
\text { respostas mais imediatas e reduzindo, substancialmente, os custos envolvidos com a } \\
\text { comunicação. }\end{array}$ \\
\hline
\end{tabular}




\section{4 - Comunicação interna e cultura organizacional}

Shein (2001) assevera que o ser humano não gosta de situações caóticas, imprevisíveis e trabalha para estabilizá-las e normatiza-las, por meio da formação de culturas. Assim, o empregado pode participar de diferentes culturas que surgem em decorrência de necessidades cultura de um país, de uma região, de uma categoria profissional ou de uma organização, com seus valores, crenças e símbolos, o que torna um ser multicultural.

O ser humano é um ser simbólico e seu universo é composto por signos, imagens, símbolos e mitos (CHANLAT, 1996). Esse caráter simbólico do homem justifica a formação da cultura organizacional, dando segurança e sentido à vida na organização. Entende-se, então, forte vinculação entre cultura organizacional e comunicação interna.

A formação da cultura organizacional está intimamente ligada ao processo de conhecimento e relacionamento. O diálogo, neste aspecto, é essencial e constrói os relacionamentos, gerando significados que podem ser transformados em conhecimento compartilhado, dependendo da realidade encontrada.

Toda a organização, a partir da sua criação e por toda a sua existência constrói um conjunto de valores, significados, padrões, criando configuração e identidade própria e que também é única, diferenciando-se, assim, das demais. Esses aspectos dão unidade e sentido à organização e permeia a ação e decisão organizacional. Ao mesmo tempo é a cultura organizacional que facilita e proporciona a adaptação, integração e convivência dos membros da organização, podendo evitar, diminuir ou até gerar conflitos. Ela é construída a cada dia, a partir de necessidades e influências dos fundadores, empregados e dirigentes. Cada um influencia e é influenciado, agregando novos valores, formando-se, ao longo do processo, a cultura organizacional.

Hall (1984) ressalta que a organização já estabeleceu um sistema de normas e expectativas a serem seguidas, independentemente de quem venha a ser o seu pessoal, o sistema continua a existir sem considerar a rotatividade desses empregados. As organizações têm políticas e fazem declarações (HALL, op. cit., p. 27). O autor ainda lembra que as organizações têm características próprias e se essas características afetam o comportamento de seus membros é 
preciso conhecer as peculiaridades organizacionais caso se pretenda entender o comportamento humano.

Com base na condição de que é necessário entender as características organizacionais para observar o comportamento humano, cabe citar Chanlat (1996) que nos três volumes da obra "o indivíduo nas organizações: dimensões esquecidas" enfatiza as questões organizacionais diretamente ligados ao comportamento do empregado no ambiente organizacional, como por exemplo, o espaço, o tempo, a doença ocupacional e a cultura. Difere de Hall (op. cit.) ao dar valor a cada empregado que integra a organização, não tratando-o como uma massa que pode ser substituída a qualquer momento e em que nada altera as rotinas da organização.

Considerando Hall e Chanlat torna-se interessante a avaliação de termos como cultura e comunicação nas organizações que, de uma forma ou de outra, interferem nas relações que as organizações estabelecem com o meio que estão inseridas e os empregados que as integram.

Os estudos culturais se tornaram importantes por fornecer elementos teóricos para a compreensão, dentro das organizações, de como se dá o surgimento de uma visão comum, a partir de experiências compartilhadas, em um dado grupo, no processo de lidar com seus problemas de adaptação externa e integração interna.

A comunicação e a cultura organizacional são reflexos de uma filosofia de administração. A comunicação é para o homem uma necessidade básica, independente do papel social e a cultura é inerente ao convívio social. A criação de cerimônias, sinais, ritos e crenças também é uma necessidade do homem. Assim, estes dois fenômenos acompanham o desenvolvimento do ser humano, estando ele dentro de uma organização ou não.

Esses dois fenômenos harmonizam expectativas. A cultura compõe um sistema de representação simbólica e a comunicação organizacional trabalha no sentido de transferência dessa representação aos seus integrantes, dirigindo seu comportamento humano, desenvolvendo em seu cotidiano as relações entre os públicos e os atores sociais, sendo a organização o palco em que acontecem tais relações. Essas relações, para o bom desenvolvimento da cultura organizacional, têm que ser harmônica, provocando o entendimento, o convívio, proporcionando, enfim, seu crescimento. 
Etzioni (1976, p. 7) assevera que:

A nossa sociedade é uma sociedade de organizações. Nascemos em organizações, somos educados por organizações e quase todos nós passamos a vida a trabalhar para organizações. Passamos muitas de nossas horas de lazer a pagar, a jogar e a rezar em organizações. Quase todos nós morreremos numa organização e quando chega o momento do funeral, a maior de todas as organizações - o Estado - precisa dar uma licença especial.

Essa citação demonstra a importância das organizações nas sociedades. E as organizações são pessoas, indivíduos com peculiaridades que não podem ser deixadas de lado nem esquecidas. Os seres humanos são a alma das organizações. Dão vida aos procedimentos, à cultura organizacional. São personagens que desenvolvem papéis por meio de processos comunicacionais, sejam eles verbais ou não.

Para Srour (1998) as organizações são sistemas abertos campos de força, logo se exigem delas uma capacidade de adaptação e muita flexibilidade. Para tal, torna-se indispensável vencer todas as barreiras apresentadas pela interdependência organizacional, ou seja, processar todas as relações de exigência, completar os requisitos solicitados, ter boas condições, administrar as ingerências, atentar às influências das comunidades que estão a sua volta, às pressões da sociedade civil, às rivalidades da concorrência, bem como alerta aos competidores potenciais. Para o autor cumprir todas essas condições não parece ser tarefa fácil, principalmente se o empregado não for considerado. A cultura de uma organização está intimamente ligada a tais funções e aos empregados que o povoam.

Schein (1992) aborda estas dificuldades de mudanças, pois a cultura representa o aprendizado acumulado dos indivíduos, dos grupos, por isso as suas partes importantes são essencialmente invisíveis, podendo ser vista, no entanto, como modelos mentais compartilhados, onde os membros da organização os adotam e os admitem como corretos. Para o autor, uma cultura é boa ou correta em função do grau com que as certezas tácitas compartilhadas criam o tipo de estratégia e organização que funcionam no ambiente da organização.

De acordo com esse autor (1992, p. 56),

Cultura organizacional é um conjunto de pressupostos básicos que um grupo inventou, descobriu ou desenvolveu ao aprender a lidar com os problemas de 
adaptação externa e integração interna que funcionaram bem o suficiente para ser validados e ensinados a novos membros como a forma correta de perceber, pensar e sentir com relação a esses problemas.

Freitas (1999) analisa as relações entre o empregado e a organização, com o intuito de entender como tais relações ativam os processos psíquicos, como a transferência, a identificação e a idealização. Destaca que na psicanálise, a transferência acontece quando um indivíduo projeta e reduz em um objeto uma atitude ou um afeto vivido em uma relação antiga, importante e duradoura. Os empregados se ligam às organizações por meio de vínculos materiais, afetivos imaginários e psicológicos que não foram criados por ele. As organizações apenas se utilizam destes vínculos. A autora ressalta a identificação como um processo psicológico onde um sujeito assimila um aspecto, uma propriedade ou um atributo do outro e se transforma total ou parcialmente no modelo em referência. Em relação à idealização, explica que é um processo pelo qual as qualidades e o valor de um objeto são elevados à categoria de perfeitos, pois o objeto é tratado como próprio ideal do ego.

Freitas (1991) apresenta dois conceitos para a cultura organizacional, frutos da evolução de suas pesquisas. Primeiramente, considera a cultura como uma sofisticada forma de controle, de poder, na busca de restauração das perdas psicológicas dos indivíduos, ao atestar que “... repondo um quadro de valores, crenças e pressupostos orientadores de um comportamento coletivo, conveniente aos seus objetivos [da organização]" (FREITAS, 1991, p. 129).

Fica evidente que a autora concorda com o pressuposto que uma cultura forte é capaz de fazer com que o empregado se molde nas normas e regras estabelecidas na organização. $\mathrm{O}$ segundo conceito apresentado por Freitas (1999, p. 97) é um tanto diferenciado e mais completo.

\footnotetext{
Entendendo cultura organizacional como instrumento de poder, segundo um conjunto de representações imaginárias sociais que se constroem e reconstroem nas relações cotidianas dentro da organização e que se expressam em termos de valores, normas, significados e interpretações visando um sentido de direção e unidade, tornando a organização fonte de identidade e de reconhecimento para seus membros.
}

Fleury (1996, p. 22) fornece o conceito de cultura organizacional, realçando também a dimensão do poder. De acordo com a autora 
[...] a cultura organizacional é concebida como um conjunto de valores e pressupostos básicos expressos em elementos simbólicos, que em sua capacidade de ordenar, atribuir significações, construir a identidade organizacional, tanto agem como elemento de comunicação e consenso, como ocultam e instrumentalizam as relações de dominação.

O modelo metodológico de Fleury (1996, p. 23-25) fornece as bases para a elaboração de um diagnóstico da cultura organizacional:

* O histórico das organizações: faz-se importante remeter-se ao contexto político e econômico da fundação da organização, de modo a entender a natureza de sua criação. $\mathrm{O}$ papel do fundador na disseminação de seus valores e crenças na construção da identidade organizacional; todos os documentos históricos, assim como vale desvendar os incidentes críticos ocorridos, tais como crises, expansões, porque nesses momentos o tecido simbólico se revela mais facilmente ao pesquisador, pois certos valores importantes de serem preservados ou, pelo contrário questionados, emergem com maior nitidez;

* O processo de socialização dos novos membros: segundo diversos autores como Berger, Schein, Van Maanen, Pagès (apud Fleury, 1996) o momento de socialização é de extrema importância para o entendimento do universo simbólico. Nesse período, os novos membros da organização vão se integrando e internalizando os valores e comportamentos válidos para aquela realidade social;

* As políticas de Recursos Humanos: as atividades de recrutamento e seleção dos novos colaboradores, desenvolvimento e treinamento, políticas de remuneração, política e processo sucessório;

* O processo de comunicação e decisão: necessita-se mapear todo o sistema de comunicações, pois a comunicação constitui um dos elementos essenciais no processo de criação, transmissão e cristalização do universo simbólico de uma organização. É preciso investigar tanto os canais (contatos diretos, reuniões, telefonemas) e os escritos, como canais informais; 
* A organização do processo de trabalho: deve-se analisar tanto na sua vertente tecnológica quanto social, no intuito de se identificarem categorias nas relações de trabalho. Essa parte do diagnóstico da cultura organizacional possibilita desvendar as relações de poder constituintes do elemento simbólico.

Fleury (1996) e Freitas (1999) compartilham de alguns pressupostos. Para Fleury o simbólico não pode ser deixado de lado quando o assunto é cultura organizacional. A autora destaca que a dimensão simbólica é capaz de integrar todos os aspectos da prática social bem como pode ser considerada uma estrutura que permite atribuir significado a certas ações e em função da qual se jogam infinitas partidas.

Freitas (1991) afirma que o estudo sobre cultura organizacional é revolucionador, contudo complexo e define como um poderoso mecanismo que visa formar condutas, homogeneizar maneiras de pensar e viver a organização, introjectar uma imagem positiva da mesma, onde todos são iguais escamoteando as diferenças e anulando a reflexão. Por outro lado, alerta que a proposta de um padrão ideal de comportamento, atitude pode ser uma agressão à intimidade de uma pessoa, pois o devoto corre o risco de reduzir ou até eliminar sua capacidade de julgamento, distorcer percepções, fechar-se em uma relação circular que anula os demais, inibir a crítica, tornando-se sombra de alguém. Em contrapartida, considera que a idealização gera uma espécie de tranqüilidade e estabilidade para as organizações, pois garante uma devoção sem interrogações e torna as pessoas capazes de se sacrificarem de boa vontade.

A autora ainda assevera que existem várias correntes e posicionamentos sobre o que é cultura organizacional e diferentes focos de pesquisa: uns tentam entender o fenômeno e outros tentam controlar o fenômeno. Contudo, existe um consenso em relação à idéia de que a cultura organizacional é algo compartilhado entre os funcionários como: crenças, valores e que isto se reflete no discurso, no comportamento, nos espaços físicos das organizações, talvez interpretadas de diferentes maneiras.

Assim como Freitas (1991) Sidnéia Freitas (2006) também ao abordar o tema cultura organizacional faz uma crítica ao modelo tradicional, mostrando-se simpática às linhas de pesquisa que resgatam o indivíduo dentro das organizações. Sidnéia Freitas (op. cit.), no artigo 
cultura organizacional e comunicação, assevera que comunicação e cultura são sinônimas. O que parece um pouco contraditório quando ela destaca e diferencia cada uma. A comunicação para esta autora assim como para Kunsch (2003) é estratégica e é por intermédio dela que se conhece a cultura da organização.

Para Marchiori (2006) cultura pode ser entendida como um processo de desenvolvimento da pessoa, de um grupo ou de uma sociedade e engloba necessariamente um entendimento de significados, credibilidade e valores entre as pessoas que, de alguma forma, sentem-se próximas e integradas. Esses valores, de acordo com a autora são criados pelas pessoas para elas próprias, por meio de interação social.

Dentre as várias funções da cultura organizacional, Robbins (2002, p. 32) afirma que:

Primeiro, ela tem uma função de definidora de fronteiras, ou seja, cria distinções entre uma organização e outra. Segundo, proporciona um senso de identidade aos membros da organização. Terceiro, facilita o comprometimento com algo maior do que os interesses individuais de cada um. Quarto, estimula a estabilidade do sistema social.

A cultura emerge na e da organização, pela socialização, por meio da interação diária entre os membros que a compõem, visando à adaptação. Ao mesmo tempo em que expressa a organização, a cultura organizacional também guia, oferecendo formas de pensar, sentir e reagir, que devem estar presentes na comunicação interna para produzir formas de comportamento desejáveis. Estas formas podem contribuir para a consecução de objetivos organizacionais e para o sucesso da organização. Como conjunto de valores compartilhados, a cultura facilita a motivação e o compromisso com a organização, não se pode esquecer, entretanto, que esses valores sofrem influência das normas, crenças e valores da sociedade. Portanto, o comportamento dos empregados, a formação da cultura organizacional e a comunicação organizacional são impactadas pelas mudanças sociais.

A cultura é algo que deve ser entendido como um produto de um processo histórico que significa construção de significados e não há como visualizar construção sem comunicação. A comunicação forma a cultura organizacional por meio da construção de significado, portanto, a cultura deve ser tratada como comunicação (MARCHIORI, 2006). A comunicação, segundo Freitas (2006) é apontada como poder para facilitar a cooperação, a credibilidade e o 
comprometimento com os valores. Então, a comunicação com sua função de construir significados e pela força que exerce nas pessoas, ao lado da cultura organizacional, como produto e produtor desse processo, pode ser planejada com vistas à efetivação dos objetivos da organização.

Kreps (1995) assevera que a cultura é algo que proporciona aos seus integrantes interpretações compartilhadas sobre a realidade. A cultura organizacional ajuda os empregados na interpretação dos fenômenos complexos, permitindo aos seus membros comportar-se de acordo com a filosofia e as metas estabelecidas pela organização. Ela é que proporciona as normas para as interpretações e reações quando da chegada do empregado na organização. Proporciona também informação aos empregados sobre como devem reagir diante de situações que a organização já tenha vivido no passado.

A comunicação se apresenta além de um canal primário utilizado para promover o desenvolvimento e a manutenção da cultura organizacional, estabelecendo uma forte relação entre ambas. A cultura organizacional aliada à comunicação torna-se um mecanismo instrumental de redução de equívocos por parte dos empregados de uma organização, dando a idéia de ordem quando da interpretação da grande quantidade de processos, metas e procedimentos apresentados pela organização. Para Kreps (1995, p. 158),

Cuando el conocimiento de los beneficios de la cultura del organización se junta con el reconocimiento del rol de la comunicación en las organizaciones como un canal penetrante de información cultural, se vuelven aparentes varias direcciones para una práctica clara de organización, las organizaciones pueden utilizar canales de comunicación formales e informales para educar a sus miembros acerca de la cultura de organización, socializarlos en la cultura y finalmente desarrollar una fuerte cultura de organización.

Nos dizeres do autor, a comunicação e a organização são atividades humanas fortemente relacionadas, a informação é variável mediadora que conecta a comunicação com a organização, sendo o resultado da comunicação que se usa para restringir e coordenar as atividades dos empregados, estabelecendo a ordem. A comunicação, processo dinâmico, contínuo, irreversível de recolhimento, envio e interpretação de mensagens permite que as pessoas compreendam sua experiência. 
Em suma, a comunicação permite às pessoas gerar e compartilhar informações que lhe proporcionam ferramentas de pensamento e direção para cooperar e organizar-se. Ao se comunicar as pessoas criam significados, trocam e respondem mensagens. A informação apresenta os dados processados dos significados criados pelas pessoas. "Es el proceso que permite a los miembros de la organización trabajar juntos, cooperar e interpretar las necesidades y las actividades siempre cambiantes de la organización” (KREPS, 1995, p. 28).

No novo contexto da era da informação, em transição para a era do conhecimento, transformado por revoluções comportamentais e tecnológicas que modificam processos e formas de interação, surge uma nova cultura organizacional que busca o entendimento, a participação e comprometimento do empregado, por meio de estratégias de comunicação organizacional. Nela o empregado é protagonista.

A comunicação clara, verdadeira e direta, que evidencia os objetivos e rumos organizacionais chama à participação, pode ser fator de sucesso das organizações, comprometer os funcionários, tornar a organização conhecida e transparente (MARCHIORI, 2006). Na perspectiva da autora, por intermédio da comunicação focada nos negócios, pode-se promover o entendimento do contexto, objetivo e dificuldades enfrentadas, forma de condução dos problemas, porquê das decisões, justificativas para posicionamentos, estratégias, formas de impacto na organização e na vida e trabalho do empregado. Ainda é possível motivar, mobilizar e criar comprometimento no empregado.

Embora nosso objetivo não seja estudar a cultura organizacional achamos importante discorrer um pouco sobre o assunto que tem estreitas ligações com a comunicação e também por nossa pesquisa ser desenvolvida em organizações que atuam em contextos diferentes e aí as diferenças culturais podem explicar algumas especificidades e nos auxiliar na compreensão de certos fenômenos. 


\section{5 - O novo contexto organizacional: de gestão de controle à gestão de comprometimento}

A administração de RH nas organizações tem sido, tradicionalmente, tratada como uma função de apoio às áreas consideradas de linha nas organizações, embora os recursos humanos sejam um dos ativos mais importantes que permeiam toda a organização e a maioria das decisões organizacionais tenham sempre implicações nesta área. O que se verifica é que a administração de recursos humanos nas organizações tem sido relegada a um status de segundo nível com pequena ou nenhuma participação entre as preocupações estratégicas das cúpulas organizacionais (ALBUQUERQUE, 1987).

Esse é um paradoxo com que deparamos na área de RH dentro das organizações em relação a sua importância. Isso é corroborado pelos achados da pesquisa Delphi RH 2010 que aponta que não é comum que as organizações tenham diretrizes explícitas para orientarem as ações de RH como também não faz parte dos rituais das grandes organizações brasileiras darem voz para o dirigente da área de RH nas suas decisões estratégicas (FISCHER; ALBUQUERQUE, 2004).

Na visão de Mills et al, (1987) no passado os altos executivos contentavam-se em delegar responsabilidades de pessoal muito definidas e limitadas a especialistas funcionais. Atualmente a grande quantidade de pressões exige uma perspectiva mais ampla, mais abrangente e mais estratégica em relação a RH na organização. Estas pressões incluem: (i) aumento da concorrência internacional, criando a necessidade de melhorias drásticas na produtividade humana, resultados em vários níveis de burocracia e elevados custos; (ii) o crescimento mais lento e declínio de mercados, afetando drasticamente a capacidade das organizações em oferecer segurança e oportunidades de progresso a seus empregados; (iii) o aumento da educação do contingente de

trabalho, obrigando as organizações a reexaminarem suas posições sobre capacidade de contribuição e participação dos empregados; (iv) a mudança de valores da força de trabalho; (v) a maior preocupação com a carreira e qualidade de vida no trabalho etc.

Em decorrência, as organizações passam a necessitar de pessoas mais autônomas e com maior iniciativa, com perfil bem diferente do exigido até então de obediência e submissão, na medida em que o processo decisório é cada vez mais descentralizado, ele fica mais sensível no 
âmbito do comprometimento das pessoas com os objetivos e as estratégias organizacionais. Assim, pode-se afirmar que o atual e grande desafio da gestão de pessoas é gerar e sustentar o comprometimento delas, o que pode ser possível se as pessoas perceberem o reconhecimento de sua importância na organização e que sua relação com a organização lhes agrega valor.

Portanto, o perfil do novo Profissional de RH está intimamente ligado a um papel mais estratégico nas organizações que de acordo com Souza (2004) parte do pressuposto de que se torna necessário o desempenho de responsabilidades mais estratégicas que as assumidas até então.

Isso porque a forma como as organizações efetuam a gestão de seus RH passa por grandes transformações em todo o mundo. Essas mudanças têm como causa os modelos tradicionais de gestão de pessoas que se mostram inadequadas no atendimento às necessidades de expectativas das organizações e das pessoas.

Do comprometimento derivam uma série de atitudes e comportamentos desejáveis: elevado grau de assiduidade e pontualidade, baixas taxas de rotatividade, atitudes positivas diante da mudança, alto desempenho individual, entre outros. Os diversos resultados proporcionados pelo alto grau de comprometimento conferem à temática relevância estratégica, tornando-na tendência em RH (ALBUQUERQUE; FISCHER, 2004).

Conseqüentemente inúmeras organizações, nos últimos anos, estão a despender uma grande quantidade de esforços com o intuito de reter pessoas com melhor qualificação e que estejam predispostas a serem comprometidas com as organizações. Os processos de recrutamento e seleção de pessoal tentam mais do que nunca prover as organizações de empregados comprometidos e com o desempenho superior.

No entanto, estudos como de Medeiros (1997) revelam que apesar dos esforços no aprimoramento dos processos de recrutamento e seleção de pessoal, o que acontece na prática é que os melhores talentos não estão sendo encontrados com facilidade. $\mathrm{O}$ estudo deste autor mostra que apenas 16\% de uma amostra de 373 empregados do setor hoteleiro pertencem ao padrão de melhor comprometimento e desempenho no trabalho, quando avaliados pelo supervisor. 
O'Reilly e Pfeffer (2001) apontam uma solução para as organizações no que refere à grande massa de empregados que não possuem um forte comprometimento com a organização, propondo a criação de sistemas de gestão de pessoas que alinhem os interesses dos empregados com os dos gerentes e acionistas em favor do benefício mútuo. Os autores asseveram que as organizações devem adotar práticas gerenciais para a obtenção de resultados extraordinários de quase todos os empregados.

Empregados envolvidos e comprometidos podem levar as organizações a competirem com mais eficácia, a reagirem em condições adversas, assim como proporcionar maior qualidade nos serviços e altos níveis de produtividade. Mais do que tudo, empregados comprometidos darão melhor de si para a organização, mesmo sem um controle rígido por parte da administração (DESSLER, 1996).

Pesquisas mostram que uma ampla gama de características organizacionais influi no comprometimento das pessoas com suas organizações. Para Fitz-Enz (1997) valores, estratégia e cultura determinam o comportamento e também são antecedentes aos sistemas organizacionais. Esses sistemas são, por sua vez, determinantes do comportamento das pessoas e dos resultados, como ressaltam Bateson e Hoffman (2001), quando afirmam que as práticas de gestão de RH são uma fonte de vantagem competitiva para as organizações.

Corroborando, Mintzberg (2001) assevera que as culturas ricas têm um enorme peso no comprometimento das pessoas no trabalho. De acordo com este autor essa cultura rica leva as pessoas a se identificarem e a terem lealdade com a organização. Essa identificação ocorre de várias maneiras: pela atração de novos membros aos sistemas de crenças da organização; pela atração de pessoas que possuem predisposição a se adaptarem aos sistemas; pelos processos informais de socialização e programas formais de doutrinamento; e porque é conveniente para os empregados se identificarem com essas crenças de uma maneira instrumental ou calculada (MINTZBERG, op. cit.).

Becker, Huselid e Ulrich (2001) ressaltam que organizações com sistemas de trabalho de alto desempenho possuem receitas por empregados $290 \%$ maiores do que as organizações em sistemas de baixo desempenho. Para apresentarem esses resultados os autores compararam os 
resultados das $10 \%$ melhores com os das $10 \%$ piores, segundo o índice de sistema de trabalho de alto desempenho (HPWS - high-performance work system), desenvolvido por eles.

Esses autores definem o sistema de alto desempenho como um sistema formado pelas políticas e práticas de alto desempenho, estrategicamente alinhadas ao sistema de recursos humanos de uma organização. Este sistema é determinado pelos profissionais de RH com competências estratégicas e determina o comportamento dos empregados. Para entender esse enfoque faz-se necessário pensar a organização dentro de um conceito sistêmico, pois as práticas e políticas de recursos humanos estão em constante interação com o ambiente empresarial, fazendo parte de um sistema aberto em que a organização está inserida e procurando um objetivo comum a toda organização.

Huselid (1995) destaca uma série de práticas de recursos humanos que influenciam o capital humano das organizações, tais como: procedimentos de recrutamento e seleção de pessoal; treinamento; sistemas de compensação; sistemas de promoção interna. $\mathrm{O}$ autor ainda destaca as estruturas organizacionais que propiciam e encorajam a participação dos empregados, quais sejam: times multifuncionais, rotatividade de trabalhos e círculos de qualidade. E numa estrutura destas, a comunicação interna integrada pode fazer grande diferença, pois se não houver uma boa comunicação interna, as pessoas podem se perder e fica difícil apresentar melhores resultados.

As novas metas dos negócios devem ser empenhadas em criar, nas organizações, ambientes de trabalho que incentivem as pessoas, procurando a execução de serviços gratificantes, que proporcionem o desenvolvimento pessoal e profissional de seus empregados (HARMAN; HORMANN, 1997).

Carlson (1987) corrobora esse pensamento ao atestar que as organizações devem liberar pessoas de um controle rigoroso, dando-lhes liberdade para assumirem responsabilidades por suas idéias, decisões e ações, possibilitando que floresçam na organização recursos antes acobertados.

Uma das principais mudanças características deste novo paradigma produtivo se refere à gestão do trabalho. As novas estratégias frente aos padrões de competitividade transformaram o 
perfil do trabalho, exigindo maior participação e iniciativas do empregado por meio de um comportamento mais ativo. Neste ambiente, a questão do comprometimento vem ganhando espaço na gestão das organizações no sentido de conjugar interesses próprios dos trabalhadores com os organizacionais.

Assim sendo, um dos principais desafios de gestão de pessoas é criar e desenvolver técnicas gerenciais que estimulem o comprometimento do trabalhador.

\subsection{1 - Estratégia de controle versus Estratégia de comprometimento}

Estudando as mudanças na organização e gestão do trabalho em indústrias norteamericanas, Walton (1997) diferencia dois tipos de estratégias de administração de pessoas: estratégia de controle e de comprometimento. A estratégia de controle está baseada no desejo de estabelecer, exercer controle, alcançar eficiência na aplicação da força de trabalho, seguindo a linha de administração científica de Taylor. Já a estratégia de comprometimento que começou a propagar-se nas organizações americanas no início da década de 70 dos anos de 1900 se baseia na diminuição de níveis hierárquicos, na junção do planejamento e da execução no desenvolvimento das tarefas, mas principalmente que o comprometimento do empregado com os objetivos mais amplos levam a organização a um melhor desempenho.

Além dessas duas estratégias o autor define uma situação intermediária chamada de Estágio Transacional, característico de organizações que apresentam-se no início do processo de transformações direcionadas à estratégia do comprometimento. Neste estágio não são contempladas mudanças nas políticas de recompensas, na organização gerencial ou no desenho de cargos. O que caracteriza esse estágio é a participação voluntária dos empregados em grupos de resolução de problemas, como os círculos de qualidade.

Na mesma perspectiva, Limongi-França (2007) apresenta dois modelos básicos de gestão de pessoas, que variam de acordo com a ênfase que se dá a autoridade, obediência, liderança, disciplina e autonomia: o modelo diretivo a que a autora também chama de diretivo-autoritário, e o modelo participativo que pode também ser chamado de consultivo-participativo. 
No modelo diretivo, as chefias usam a autoridade formal e a burocracia para ter o respeito e obediência dos subordinados, usando-se de métodos e instrumentos coercitivos de repreensão, em caso de necessidade. As organizações que usam esse modelo de administração, também designadas de mecanicistas, tendem a ter uma estrutura centralizada e uma estrutura de cargos definida ao pormenor, sem deixar autonomia para quem ocupa o cargo. Com esse estilo de gestão, as pessoas não são comprometidas com a organização e, por isso, sem preocupação com o alcance dos objetivos organizacionais.

Já o modelo participativo defende a autonomia, liderança e disciplina, como princípios da gestão de pessoas. As pessoas são responsáveis pelo seu desempenho e comportamento. A obediência, disciplina e respeito pelos chefes não são impostos por normas e procedimentos coercitivos. Nesse modelo de gestão, as pessoas tendem a estar comprometidas com a organização, na medida em que se sentem parte dela.

Dentro dessa mesma linha, Albuquerque $(1992 ; 1999 ; 2002)$ distingue organizações que se contrapõem numa antiga e numa nova concepção em relação a três conjuntos de características organizacionais, a saber:

* Características relacionadas à estrutura organizacional, compreendendo hierarquização, sistemas de produção, forma de organização do trabalho e sistemas de controle;

- Características relacionadas a relações de trabalho, compreendendo o nível de educação e formação requerido pelo trabalho; relações de independência e confiança entre empregador-empregado; relações com o sindicato e a participação dos empregados nas decisões;

* Características relacionadas às políticas de recursos humanos, especialmente emprego; contratação; treinamento; carreiras; política salarial e de incentivos. De acordo com o autor as organizações da nova concepção, que possuem uma estratégia de comprometimento, devem buscar a qualificação e o desenvolvimento do trabalhador, uma relação de emprego mais duradoura, trabalho em grupo que facilitam a 
comunicação e a participação na organização. Tudo isso aliado a um conjunto de práticas vinculadas aos subsistemas de gestão de recursos humanos.

Albuquerque (1999, p. 232) no seu estudo que objetivou identificar quais seriam as grandes tendências de mudanças no sistema de Gestão de Recursos Humanos e nas relações de trabalho que possibilitariam às organizações brasileiras aumentarem sua competitividade empresarial concluiu que estas organizações deverão assumir como premissas as necessidades de:

Valorização dos talentos humanos na empresa - trata-se de gerir o trabalho e as pessoas e não simplesmente recursos ou números; b) atração e manutenção das pessoas de alto potencial e qualificação para trabalho; c) criação de condições favoráveis à motivação individual e à mobilização dos grupos em torno das metas organizacionais; d) possibilidades de crescimento funcional e desenvolvimento profissional na própria empresa; e) oferecimentos de incentivos vinculados a resultados da atividade empresarial, de preferência com base grupal e coletiva; f) adaptação de políticas integradas de recursos humanos à realidade da empresa e ao contexto externo econômico-social e político no qual atua [...] Essas premissas, específicas para a concepção das novas políticas de recursos humanos, complementam a proposição maior, orientação para os resultados.

O autor ressalta que as políticas de Recursos Humanos nessa nova concepção devem contemplar os processos de contratação, treinamento, carreiras, remuneração e relações sindicais e que o modelo apresentado fornece os contornos de uma estratégia de comprometimento da força de trabalho para a busca de resultados empresariais e de vantagens competitivas sustentáveis.

Verifica-se que quanto mais as organizações buscam flexibilidade e velocidade decisória - para competir num contexto em que os mercados se entrelaçam, no ambiente onde a única certeza é a incerteza, os consumidores são percebidos individualmente e a competitividade dita as regras - mais dependem de pessoas. Conseqüentemente tornam-se mais dispostas a atender as expectativas e necessidades que elas manifestam.

Dutra (2004) assevera que as pessoas que estabelecem algum tipo de relação de trabalho com a organização, por seu lado, procuram satisfazer um novo conjunto de necessidades: maior espaço para desenvolvimento pessoal e profissional, manutenção da competitividade profissional e exercício da cidadania organizacional, pressionando assim a organização a se estruturar para tanto. 
Essas pressões exigem uma revisão de conceitos, técnicas e ferramentas. Essas exigências juntamente com a crescente importância do elemento humano para construir e manter diferenciais competitivos para a organização originaram maior atenção à gestão de pessoas.

Embora desde os anos 80 fala-se em rever a forma de gestão de pessoas e repensar conceitos e ferramentas de gestão, só a partir dos anos 90 é que surgem propostas mais concretas de mudança.

De acordo com Dutra (2004) as principais transformações observadas na forma de gerir pessoas no período de 90 e 2000 foram:

* Alteração no perfil das pessoas exigido pelas empresas: o perfil de empregado obediente foi substituído pelo perfil de empreendedor. A mudança no padrão de exigência gerou a necessidade de uma cultura organizacional que estimulasse e apoiasse a iniciativa das pessoas, a criatividade e a busca autônoma de resultados para a empresa ou para o negócio;

Deslocamento do foco de gestão de pessoas do controle para o desenvolvimento: no paradigma fordista e taylorista em que a gestão de pessoas tem como foco o controle, as pessoas são objeto de controle e espera-se delas uma postura passiva. Com a mudança do perfil exigido pelas organizações há uma pressão para que a gestão de pessoas seja marcada pela idéia de desenvolvimento mútuo (empresa/pessoa).

Maior relevância das pessoas no sucesso do negócio ou da empresa: o comprometimento das pessoas com a empresa ou negócio de forma integral gera vantagens competitivas. As pessoas são as depositárias do patrimônio intelectual da organização, da capacidade e agilidade de resposta da empresa aos estímulos do ambiente e da capacidade de visualização e exploração de oportunidades de negócio.

Para subsidiar a formulação das políticas de RH a administração de RH precisa contar com um sistema de informações, com dados sistematizados que subsidiem a tomada de decisão desta área, ou seja, parte-se da premissa de que decisões objetivas em RH dependem da 
disponibilidade de informações em nível do ambiente, de organização, dos trabalhos realizados e dos empregados que compõem o seu quadro.

Por outro lado, para que a organização consiga obter o comprometimento dos seus empregados, não basta a definição de política que se enquadram nas categorias definidas por Dessler (1996) que são o conjunto dos oito valores. É necessário implementá-los com eficácia por meio de gestores qualificados, com perfis bem definidos, de acordo com as exigências das funções que cada um desempenhará na organização.

Seja como estratégia de gestão de pessoas, seja como instrumento de análise do comportamento humano na organização ou ainda como facilitador das relações empregadoorganização, a questão do comprometimento aparece em todas as situações como uma forte tendência nas práticas de Gestão de Pessoas frente à emergência da concepção ligada ao paradigma de flexibilidade.

A necessidade do comprometimento das pessoas foi ampliando sua importância estratégica para criar e, sobretudo, manter diferenciais competitivos por parte das organizações. Ao ganharem voz dentro das organizações, as pessoas se tornam uma fonte de pressão, a segunda fonte de pressão sobre a organização, uma pressão proveniente do contexto interno. E para que isso aconteça é necessário que a organização tenha uma comunicação interna integrada com políticas globais, estabelecidas, estratégias delineadas e programas de ação voltados para todo o pessoal do ambiente interno e dispor de canais e instrumentos diversos que permitem todas as áreas da organização atuarem sinergicamente (KUNSCH, 2003).

Vale ressaltar que essa comunicação que se espera efetiva aconteça de fato, dando possibilidade a todos os colaboradores de ao comunicarem recebam o feedback necessário, pelo menos em relação à realização dos seus trabalhos.

\section{6 - Componentes do comprometimento organizacional}

O comprometimento do empregado com a organização vem sendo estudado com o declínio do modelo taylorista, estabelecendo com a integração empregado-organização, uma 
conexão entre satisfação e a produtividade. Todas as mudanças contextuais verificadas estimulam a comunidade científica e as próprias organizações a buscarem subsídios na compreensão da relação empregado-organização e todas as atitudes que a permeia - os antecedentes, correlatos e conseqüentes (MORAES; KILIMNIK, 1995; MOWDAY, 1998).

A grande maioria dos estudos sobre comprometimento desenvolveu-se na vertente organizacional, gerando por vezes a noção desta ser sinônimo de comprometimento individual. Os estudos sobre comprometimento com o trabalho, a carreira e a profissão vêm em seguida, muitas vezes integrando modelos explicativos de comprometimento organizacional. Além disso, a pesquisa sobre comprometimento organizacional encontra-se fragmentada em cinco grandes abordagens:

* Afetiva ou atitudinal, relacionada à natureza do processo de identificação do empregado com os objetivos e valores da organização;

* Instrumental, também chamado side-bets, trocas laterais ou ainda calculativo, relacionada às recompensas e custos associados à permanência na organização;

* Normativa, relacionada ao conjunto de pressões normativas internalizadas para o comportamento congruente do empregado para com a organização;

* Comportamental, relacionada a comportamentos ou atos com cognições que fortalecem tais vínculos, como o sentimento de auto-responsabilidade;

- Sociológica, sobre as relações de autoridade que governam o controle do empregador e a subordinação do empregado.

A literatura sobre comprometimento organizacional foi dominada por muito tempo pelo enfoque afetivo, a partir de trabalhos desenvolvidos pela equipe liderada por Lyman e Porter (MOWDAY et al, 1979; MOWDAY et al, 1982). Estes trabalhos reconhecem a existência de uma corrente comportamental de definir o comportamento embora assumindo-o numa perspectiva atitudinal. Para estes autores o comprometimento vai além de uma postura de 
lealdade passiva com a organização, envolvendo também um relacionamento ativo que busca o bem-estar da organização.

O constructo comprometimento organizacional pode ser caracterizado por no mínimo três fatores: “(i) uma forte crença e a aceitação dos objetivos e valores da organização; (ii) estar disposto em exercer um esforço considerável em benefício da organização; e (iii) um forte desejo de se manter membro da organização" (MOWDAY et al, 1982, p. 27).

Esses autores começaram a desenvolver trabalhos relacionados ao comprometimento no início da década de 70 e culminaram com a validação de um instrumento para se medir o comprometimento, o OCQ - Organizational Commitment Questionnaire (MOWDAY et al, 1979). No Brasil o instrumento foi validado por Borges-Andrade, Afanasief e Silva (1989).

O segundo enfoque mais considerado na área é o enfoque instrumental do comprometimento organizacional que deriva dos estudos de Becker (1960). Esta autora descreve comprometimento instrumental como uma tendência do empregado em se engajar em linhas consistentes de atividade. Esse comprometimento é também chamado de side bet, que pode ser traduzido com as trocas laterais, assumindo diversos rótulos, como bem ressalta Bastos (1994) tais como calculativo e continuance ou continuação. Para Becker o empregado permanece na organização devido aos custos e benefícios associados a sua saída que seriam as trocas laterais e assim passa a se engajar em linhas consistentes de atividade para se manter no emprego. Assim, a noção de linhas consistentes de atividades implica em uma escolha, por parte do empregado, de um curso de ação dentre diversas alternativas, daquela que melhor atende a seus propósitos (BECKER, 1960).

O enfoque normativo é apresentado nos trabalhos de Wiener (1982); Kanter (apud Mowday et al, 1982), publicado em 1968. Wiener (op. cit., p. 412) conceitualiza o comprometimento como totalidade das pressões normativas internalizadas para agir num caminho que encontre os objetivos e interesses organizacionais. $\mathrm{O}$ autor enfatiza que o elemento central da definição do comprometimento em aceitar os valores e objetivos organizacionais, representa uma forma de controle sobre as ações das pessoas, o qual denomina de normativoinstrumental. Para o autor, empregados comprometidos exibem certos comportamentos porque acreditam que é certo fazê-lo. 
Segundo esse autor a visão normativa do comprometimento sugere um foco centrado nos controles normativos por parte das organizações, tais como normas e regulamentos ou ainda como uma missão forte e disseminada dentro da organização. Essa visão é similar à do Kanter (apud Mowday et al, 1982) que assimila que as normas e valores da organização moldam o comportamento do empregado na direção desejada pela organização. Enfoques mais modernos de comprometimento utilizam modelos multidimensionais, ou seja, consideram que o comprometimento traduz-se nas diversas dimensões, conforme explanado a seguir.

\section{7 - Modelos multidimensionais do comprometimento organizacional}

Os modelos multidimensionais do comprometimento organizacional tiveram início a partir do momento que alguns pesquisadores perceberam que os enfoques unidimensionais eram componentes presentes no vínculo psicológico entre empregado e organização. Alguns autores utilizam expressões distintas para descrever a presença de mais de um componente no comprometimento.

Mowday et al, (1982) denominam de tipologias de comprometimento. Becker (1992) chama as diversas dimensões como base do comprometimento. Meyer e Allen (1991) denominam de componentes do comprometimento. Todos estes autores estão se referindo a componentes do constructo comprometimento organizacional. Meyer e Allen (1991) argumentam que o termo componente é mais apropriado para se descrever as dimensões do comprometimento, uma vez que as relações empregado-organização refletem vários graus de cada um desses componentes.

$\mathrm{O}$ primeiro autor a estabelecer o comprometimento em componentes diferentes foi Kelman, em 1958, distinguindo o vínculo psicológico de um empregado com a organização em três bases independentes:

* Compliance (submissão): envolvimento instrumental motivado por recompensas extrínsecas;

* Identification (identificação): envolvimento baseado num desejo de afiliação; 
Internalization (internalizacão): envolvimento causado pela congruência entre valores individuais e organizacionais.

Gouldner (1960), acreditando que o comprometimento é um constructo multidimensional, realizou uma pesquisa com o intuito de identificar os componentes do comprometimento organizacional e identificou duas dimensões para o comprometimento:

* Integração - grau em que um empregado é ativo e se sente parte em vários níveis de uma organização em particular;

* Introjecção - grau em que própria imagem de um empregado inclui uma variedade de características e valores organizacionais aprovados.

O autor ressalta que se sentir parte de uma organização é diferente de introjectar características e valores organizacionais.

Etzioni (apud Mowday et al, 1982) sugeriu uma classificação em que o envolvimento do empregado pode assumir três formas:

* Envolvimento moral: baseado na internalizacão dos objetivos, valores e normas da organização. Sendo este envolvimento positivo e intenso na direção dos objetivos organizacionais;

* Envolvimento calculativo: baseado nas relações de troca que se desenvolvem entre o membro e sua organização. Este envolvimento é uma relação de menos intensidade e ocorre quando o membro percebe equidade entre recompensas e contribuições;

* Envolvimento alienativo: baseado na repressão e na coerção. Este envolvimento tem uma orientação negativa e é encontrado em ambientes como prisões. 
Outro trabalho que trouxe nova classificação foi o de Kanter (apud Mowday et al, 1982). A autora identificou três diferentes formas de comprometimento:

* Comprometimento de coesão: vínculo às relações sociais de uma organização realizada por intermédio de técnicas e cerimônias que tornam público o estado de ser um membro da organização e que reforçam a coesão do grupo;

* Comprometimento de continuação: requer dos membros da organização a reflexão de sacrifícios pessoais e de investimentos que tornam difícil aos membros deixar a organização;

* Comprometimento de controle: vínculo de um membro às normas de uma organização que moldam seu comportamento numa direção desejada.

O modelo de Meyer e Allen (1997) já validado em várias culturas é internacionalmente aceito. Os autores conceitualizam o comprometimento em três componentes:

* Comprometimento afetivo: comprometimento como um apego, como envolvimento, onde ocorre identificação com a organização. De acordo com os autores empregados com um forte comprometimento afetivo permanecem na organização porque querem;

* Comprometimento instrumental: comprometimento percebido como custos associados a deixar a organização. Segundo os autores, empregados com comprometimento instrumental permanecem porque precisam;

* Comprometimento normativo: comprometimento como uma obrigação em permanecer na organização. Para os autores, empregados com comprometimento normativo permanecem porque sentem que são obrigados.

Dentro dessas abordagens, a afetiva é a mais amplamente estudada, tendo sido marcada pelo clássico estudo de Mowday et al, (1982), com enfoque unidimensional. Aqui o elo passa a 
enfatizar a natureza afetiva, tendo presentes três dimensões básicas: (i) o sentimento de lealdade; (ii) desejo de permanecer como parte da organização; (iii) a identificação com a organização, seus valores, sua cultura, suas metas, como o esforço pessoal dirigido para o alcance dos objetivos e metas organizacionais.

A segunda abordagem mais importante em sua presença na literatura é a instrumental, embora todas estas abordagens organizacionais sejam bastante estudadas. O comprometimento sob o enfoque instrumental é um mecanismo psicossocial, cujos elementos são função das recompensas ou custos associados à condição de membro da organização (THOMAS BECKER, 1992). Os múltiplos investimentos que o empregado vem fazendo ao longo de sua permanência na organização, como desenvolvimento de habilidades e competências passam a representar um peso elevado na decisão de deixar a organização. Esse enfoque parte da premissa de que atendidas as expectativas e as necessidades que o empregado apresenta no contexto do trabalho se firmam fortes vínculos empregatícios.

O comprometimento normativo embasado na convergência de considerações da teoria organizacional proposta por Etizioni (1976) e psicologia social caracteriza-se como um conjunto de pressões que agem sobre o empregado ou por ele internalizadas, de forma que o mesmo crie um comportamento que leve ao conveniente cumprimento dos objetivos e interesses organizacionais.

As escalas desenvolvidas por Meyer e Allen são de dois tipos, uma com 24 itens e outra reduzida com 18 itens (Meyer et al, 1993). As escalas trazem questões fechadas sobre comprometimento organizacional e são aplicadas no formato Likert. Um terço dos indicadores do instrumento é do comprometimento afetivo e os outros são referentes ao comprometimento normativo e instrumental. A principal contribuição de Meyer e Allen (1991) ao estudo foi a operacionalização das teorias do comprometimento organizacional.

O modelo de conceitualização de três componentes do comprometimento organizacional foi validado inicialmente no Brasil por Medeiros (1997), seguido por Ricco (1998) e Bandeira et al, (1999). Neste estudo os autores obtiveram os três componentes conceitualizados por Meyer e Allen (1991), mas encontraram índices moderados de consistência interna para os três 
componentes da teoria e baixo percentual de variação total, o que denota a existência de indicadores pouco adequados dentro do instrumento.

O quadro 3, a seguir, apresenta de forma sucinta os enfoques multidimensionais do comprometimento com os seus respectivos autores e realça o ponto de convergência e divergência entre esses autores.

Quadro n 3 - Perspectivas multidimensionais de comprometimento

\begin{tabular}{|c|c|}
\hline Descrição e autores & Dimensões \\
\hline $\begin{array}{l}\text { Representa uma das dimensões conceitualizadas por Mowday et. al, (1982): uma forte } \\
\text { crença e a aceitação dos objetivos e valores da organização. O fator demonstra o } \\
\text { envolvimento causado pela congruência entre os valores individuais e organizacionais } \\
\text { como proposto por Kelman (1958) ao conceitualizar a base de internalização e também a } \\
\text { introjecção dos valores organizacionais proposta por Gouldner (1960). A dimensão ainda } \\
\text { confirma o que Etzioni (apud Mowday et. al, 1982) designa de envolvimento moral, } \\
\text { baseado na internalização dos objetivos, valores e normas da organização, sendo este } \\
\text { envolvimento positivo e intenso na direção dos objetivos da organização. }\end{array}$ & $\begin{array}{l}\text { Afetivo } \\
\text { Internalização de } \\
\text { valores e objetivos } \\
\text { organizacionais }\end{array}$ \\
\hline $\begin{array}{l}\text { O comprometimento afiliativo é distinto do comprometimento afetivo, como conceituado } \\
\text { por Kelman (1958) e por Becker (1992). A dimensão também corresponde ao conceito } \\
\text { de Gouldner (1960) que aponta duas dimensões para o comprometimento, sendo uma } \\
\text { delas a dimensão integração, descrito pelo "grau em que um trabalhador é ativo e sente } \\
\text { parte, em vários níveis, de uma organização em particular". Este autor ressalta que se } \\
\text { sentir parte de uma organização é diferente de introjectar características e valores } \\
\text { organizacionais. }\end{array}$ & $\begin{array}{c}\text { Afiliativo/ Integração } \\
\text { Sentimento de fazer } \\
\text { parte }\end{array}$ \\
\hline $\begin{array}{l}\text { Designa um sentimento de obrigação em permanecer. Meyer e Allen (1991) } \\
\text { conceitualizam o comportamento normativo como uma obrigação em permanecer na } \\
\text { organização e os trabalhadores com este vínculo permanecem na organização porque } \\
\text { sentem que são obrigados. }\end{array}$ & $\begin{array}{l}\text { Normativo } \\
\text { Sentimento de } \\
\text { obrigação em } \\
\text { permanecer na } \\
\text { organização }\end{array}$ \\
\hline $\begin{array}{l}\text { Demonstra um sentimento de obrigação por parte do trabalhador em buscar atingir os } \\
\text { objetivos da organização. De acordo com Wiener (1982) o enfoque normativo do } \\
\text { comprometimento aventa um foco centrado nos controles normativos por parte da } \\
\text { organização, tais como normas e regulamentos ou ainda como uma missão forte e } \\
\text { disseminada dentro da organização. }\end{array}$ & $\begin{array}{l}\text { Normativo } \\
\text { Sentimento de } \\
\text { obrigação pelo } \\
\text { desempenho }\end{array}$ \\
\hline $\begin{array}{l}\text { Denota um desequilíbrio na relação entre recompensas e contribuições, aliado ao } \\
\text { sentimento de falta de oportunidade e reconhecimento por parta da organização. Esse } \\
\text { sentimento pode ser traduzido segundo Etzioni (apud Mowday et. al, 1982) ao definir o } \\
\text { envolvimento calculativo, que é baseado nas relações de troca que se desenvolvem entre } \\
\text { o membro e a organização. Para o autor este envolvimento é uma relação de menor } \\
\text { intensidade e ocorre quando o membro percebe equidade entre recompensas e } \\
\text { contribuições que no caso desses indicadores parece não ocorrer. }\end{array}$ & $\begin{array}{l}\text { Instrumental } \\
\text { Sentimento de falta de } \\
\text { recompensas e } \\
\text { oportunidades }\end{array}$ \\
\hline $\begin{array}{l}\text { Indica o sentimento dos trabalhadores em se engajar em linhas consistentes de } \\
\text { atividades. A dimensão corrobora a teoria side bets proposta por Becker (1960) segundo } \\
\text { a qual o trabalhador permanece na organização devido aos custos e benefícios associados } \\
\text { a sua saída que seriam as trocas laterais e, portanto passa a se engajar em linhas } \\
\text { consistentes de atividade para se manter no emprego. }\end{array}$ & $\begin{array}{c}\text { Instrumental } \\
\text { Linhas consistentes de } \\
\text { atividades }\end{array}$ \\
\hline $\begin{array}{l}\text { Representa a existência de poucas alternativas ao trabalhador, caso saia da organização. } \\
\text { Segundo Meyer e Allen (1991) o comprometimento instrumental é percebido como } \\
\text { custos associados a deixar a organização, e os trabalhadores com esse tipo de } \\
\text { comprometimento permanecem na organização porque precisam. }\end{array}$ & $\begin{array}{c}\text { Instrumental } \\
\text { Escassez de alternativas }\end{array}$ \\
\hline
\end{tabular}




\section{8 - Possíveis relações entre comprometimento e comunicação interna}

Na visão de Marchiori (2006.) o que possibilita a execução das atividades para o alcance dos objetivos organizacionais é a geração de proximidade, o sentido às experiências e o aprimoramento dos relacionamentos, no sentido de construir conhecimento. Essa proximidade pode se dar por meio de três tipos de relações internas apresentadas por Piñuel Raigada (1997): i) relações estritamente profissionais, ligadas à atividade da organização, cujos membros são agentes produtores por normas e regras e que têm os meios para a produção de bens ou serviços; ii) relações de convivência, que é a comunicação informal entre os sujeitos e iii) as relações de identidade, associadas à cultura da organização, entendida como um conjunto de hábitos que funcionam como códigos para fixação de significados.

Nota-se que os vários tipos de relações, direta ou indiretamente, ocorrem em torno dos objetivos organizacionais, além de serem pautados na cultura organizacional. Portanto, a comunicação interna e a cultura organizacional, determinantes no comportamento do empregado, andam lado a lado na busca do sucesso e eficácia da organização.

O empregado precisa de informação para compartilhar do entendimento da visão da organização, construir sentimento de pertencimento, envolver-se e comprometer-se com as estratégias e objetivos da organização. Isso requer interação e diálogo. Os funcionários só se comprometem com os objetivos organizacionais a partir do momento em que estiverem informados e integrados em um determinado contexto, o que exige contínua troca de informações e alteração de comportamentos da organização e dos próprios funcionários. Troca de informação, mudança de comportamento e comprometimento só se dá pela comunicação. A autora vai além afirmando que o sucesso organizacional depende das habilidades de comunicação da organização e por isso estas podem e devem ser vistas como fenômenos da comunicação (MARCHIORI, 2006).

Verifica-se que o processo básico de toda a comunicação humana é o de atribuir sentido, significação ou qualidade de mensagem aos dados e fatos que se quer transmitir e esse processo ocorre no nível intrapessoal, dentro da pessoa, ou seja, a pessoa ao receber a mensagem percebe-a e interpreta-a. Assim, neste nível, podemos estudar cuidadosamente quais são os fatores que podem atrapalhar a comunicação, pois é dentro das pessoas que realmente a comunicação se 
efetiva. Isso nos leva a concluir que comunicação é diferente de receber informações, pois as informações precisam ser compreendidas e a partir daí gerar um feedback.

Percebe-se as práticas tradicionais de gestão de recursos humanos como a de captar, alocar, manter, treinar, remunerar ou recompensar, têm apresentado tendências modernizantes. Estão se estruturando transformações nas políticas e nas relações de trabalho e cresce a responsabilidade das práticas de gestão de recursos humanos. Cabe-lhes formação de novas competências, orientação e consultoria ao corpo gerencial, preparação e acompanhamento das mudanças organizacionais, promoção do trabalho em equipe e implementação de relações sociais.

Assumir essas responsabilidades vai exigir dos gestores de recursos humanos e de linha uma postura de envolvimento e comprometimentos. Dessler (1996, p. 7) expressa essa necessidade ao garantir que:

O gerente comprometido agirá de acordo com os interesses da organização, exatamente como se fossem seus, pois veio a percebê-los como idênticos, o modelo de fracasso pessoal e o atrativo de recompensas financeiras (apenas) não podem desencadear o mesmo grau de criatividade ou o tipo de interesse zeloso que resulta da dedicação ao objetivo compartilhado da empresa.

Portanto, um processo de comprometimento deve passar por toda a estrutura organizacional. A alta e a média direção de uma organização devem expressar com clareza os objetivos organizacionais e também diagnosticar os objetivos individuais de empregados, clientes e fornecedores. Devem, também, diagnosticar as variáveis externas que afetam a organização. Como fator decisivo nesse processo de envolvimento está a comunicação em todos os níveis.

Vários são os estudos que apontam a importância da comunicação no desenvolvimento do comprometimento organizacional.

Tavares (2005) realizou um estudo sobre a importância da comunicação interna para o desenvolvimento do comprometimento organizacional, onde desenvolveu um estudo de caso, numa empresa brasileira do setor de Engenharia e Tecnologia - telecomunicações e tecnologia de informação -, buscando relação entre comunicação interna e comprometimento dos colaboradores. Os resultados indicaram que existe uma forte dependência e associação entre a 
comunicação interna, planejamento da comunicação organizacional e o comprometimento, permitindo concluir que o comprometimento afetivo está associado à comunicação interna integrada.

Watkins (1992) analisando as relações entre comunicação, comprometimento e percepção de apoio organizacional, a partir da percepção dos colaboradores de uma universidade, concluiu que entre outras a qualidade da comunicação da alta administração e a comunicação superiorsubordinado estavam fortemente relacionados ao comprometimento organizacional.

Na mesma linha, Eisenberg et al, (1983) investigando a relação entre o envolvimento em um trabalho de rede de comunicação e comprometimento organizacional encontrou que existe uma relação complexa entre o grau de envolvimento e a comunicação. No entanto, realçaram que o impacto da participação em redes de comunicação sobre atitudes e comportamentos dos trabalhadores pode ocorrer apenas em empregados com determinadas características.

Postmes et al, (2001) asseveram que na relação entre comunicação e compromisso observa-se com freqüência que a comunicação cria condições para o compromisso nas organizações e assim deveria ser vista como um de seus antecedentes importantes. Corroborando, Albuquerque (1999) destaca papel do processo de comunicação da organização como fator fundamental na estratégia de comprometimento dos colaboradores para o alcance de melhores resultados empresariais.

Seguindo essa mesma perspectiva Scheible e Bastos (2006) referindo-se às práticas vitais de gestão do comprometimento, apontaram as práticas de comunicação como as mais importantes. Meyer et al, (1998) alegam que algumas práticas de gestão, tais como oportunidades de treinamento, encorajamento para uma maior participação nas decisões, mudança de abordagem por parte das lideranças, entre outras contribuem positivamente para 0 desenvolvimento do comprometimento. Entende-se que para que haja participação tem que haver comunicação.

Tomlinson (2010) ao examinar o motivo que leva o empregado a se engajar dentro de uma organização, desenvolveu um estudo de caso na empresa automobilística Sul Koreana, Kia Motors, e aponta como uma das práticas de gestão que leva a esse engajamento a comunicação 
interna. Ressalta o autor que as empresas devem dispor de ferramentas que facilitem a comunicação entre funcionários e aperfeiçoar os canais de comunicação interna para construção do engajamento, assegurando uma comunicação consistente com os empregados e a gerência.

Alexander et al, (2009) ao apresentarem achados de uma pesquisa recente sobre boas práticas de comunicação interna em empresas e como estas práticas funcionam em diferentes organizações apontam como tendência a importância do engajamento dos empregados no papel e propósito da comunicação interna.

Chang Jr. (2001) assevera que a comunicação é uma das variáveis que precedem o comprometimento dos funcionários. Ela é essencial para o bom funcionamento de qualquer tipo de instituição, pois é por meio dela que uma organização se relaciona com o meio ambiente e suas partes. De acordo com este autor o processo de comunicação reveste-se de importância ímpar quando se pensa numa organização como um conjunto de esforços humanos organizados, pois o resultado final não será alcançado por uma só pessoa. Todos os resultados alcançados pela organização são frutos do esforço de funcionários (CHANG JR, 2001, p. 36).

No entanto, é importante realçar que a comunicação a que se refere não deve ser entendida como sinônimo de recepção de informação. Comunicação é um processo que envolve diversos dimensionamentos tais como: transmissão da mensagem do remetente para o receptor; recepção e compreensão desta mensagem; e sua aceitação ou rejeição (LIKERT, 1971).

Compartilhando deste pensamento encontra-se Lite (1997) que assim como Kunsch (1997) destaca a importância da comunicação interna dentro das organizações, mas defende a idéia de que a comunicação dentro das organizações não é muito diferente do que o simples envio de informações.

A cada passo se emprega o termo comunicação como se todo o material que é transmitido fosse compreendido e aceito. Por exemplo, toma-se como fato que a informação colocada diante dos colaboradores foi comunicada a eles, isto é, compreendida e aceito por eles. Isso pode ou não ser verdadeiro.

A comunicação é muito mais complexa e depende de diversos fatores, não se limitando somente a transmissão de uma mensagem. Para haver uma comunicação é necessário que duas ou 
mais pessoas entendam a mesma mensagem com o mínimo de distorção do que foi originalmente emitida. Entenda-se aqui distorção: fenômenos dos mais diversos tipos, não necessariamente relacionados a ruídos físicos.

Likert (1971, p. 63-4), ao definir comunicação num ambiente empresarial, chama atenção para o fato, fazendo algumas considerações, tais como:

A comunicação é um processo complexo que envolve diversos dimensionamentos [...] 1) é a transmissão de material do remetente para a audiência-alvo: 2), a recepção e compreensão desse material; 3) a sua aceitação ou rejeição [...] Outro fator que dificulta o processo de comunicação é a diversidade na natureza do material transmitido. Existe material cognitivo, tal como a) informações ou fatos relativos a situações coerentes, problemas, progresso na direção das metas etc; b) idéias, sugestões, experiências; c) conhecimento relativo a objetivos, políticas e ações. Material motivacional e emocional, tal como: a) clima ou ambiente emocional; b) atitudes e reações; c) lealdades e hostilidades; d) sentimentos de apoio, apreciação ou rejeição; e) metas e objetivos. Em vista dos complexos processos e da natureza variada do material, não é surpreendente que o processo de comunicação tantas vezes se desmantele. Somem-se a isso as atitudes desfavoráveis por parte dos membros da organização que criam sérias barreiras à transmissão e aceitação das informações.

O autor nos seus estudos evidencia alguns fatos que se correlacionam com a comunicação num contexto empresarial:

* Quanto maior for a pressão descabida sentida pelos colaboradores, tanto maior será a dificuldade que sentem ao procurar comunicar idéias para a melhoria das operações aos níveis superiores da administração;

* Hostilidade, medo, desconfiança e atitudes similares tendem não só a reduzir o fluxo e a aceitação de informações relevantes, mas a gerar motivos para distorcer comunicações descendentes e ascendentes. Confiança recíproca por parte dos membros de uma organização parece ser necessária para que o processo de comunicação funcione eficientemente;

* As teorias clássicas de administração colocam em primeiro plano o controle, a cadeia de comando e o fluxo descendente de ordens de influência. Destaque correspondente não é dado à comunicação ascendente adequada e exata; 
* Quanto mais alta for a produtividade, maior será a precisão das percepções. A boa comunicação e o bom desempenho caminham juntos e a facilidade de transmitir idéias ascendentemente está associada com a eficiência departamental;

* Os supervisores sempre superestimam a importância que seus subordinados dão aos fatores econômicos e subestimam a que dão aos fatores humanos tais como: dar-me bem com as pessoas com quem trabalho, dar-me bem com meu supervisor, ter boas chances de produzir trabalho de boa qualidade, dentre outros;

* Os mestres estão muito mal informados quanto à motivação de seus subordinados. Tanto uns como outros seriam bastante mais exatos em suas estimativas se supusessem que os valores e metas de seus subordinados eram, em essência, os mesmos que o deles próprios;

* Os dados revelaram que os superiores não deixam claro aos subordinados qual, precisamente, é a sua tarefa e o que se espera deles. Os superiores julgam que a capacidade de planejar ou organizar e de solucionar problemas é parte importante da tarefa do subordinado, enquanto os subordinados não pensavam assim;

Há falta quase total de entendimento entre subordinados e superiores sobre as dificuldades encontradas pelos primeiros no trabalho. Contribuindo ainda mais para essas falhas nas comunicações, encontra-se pouca vontade dos subordinados em trazer seus problemas à presença do homem que detém o controle supremo de seus destinos na organização. A influência deste sobre suas promoções e seu futuro na companhia é tão grande que não se pode permitir que ela veja suas fraquezas. Partilharão seus êxitos com o chefe, mas não seus insucessos.

Apesar do autor não ter como objetivo verificar associação entre a comunicação e comprometimento menciona a existência de uma associação entre comunicação e produtividade considerada como variável conseqüente do comprometimento - e entre lealdade grupal considerada como variável correlata ao comprometimento - e comunicação entre os membros do grupo. 
Compartilhando do mesmo ponto de vista, Dessler (1996) aponta a comunicação como um dos principais fatores de comprometimento. O autor afirma que o comprometimento é formado com base em confiança e que confiança requer um fluxo de comunicação de mão dupla. As organizações detentoras de grande comprometimento possuem programas formais para garantir esse tipo de comunicação. $\mathrm{O}$ autor cita alguns deles: i) tratamento justo garantido, no qual são analisadas e arquivadas queixas e reclamações, programas que permitem falar abertamente, para abrir um espaço de livre comunicação e fazer indagações; ii) programas de pesquisa periódica, para expressar opiniões; iii) programas de cima para baixo, para manter os colaboradores bem informados.

$\mathrm{O}$ autor elenca as práticas administrativas que criam comprometimento dos empregados das organizações que analisou no seu estudo. Salienta que não necessariamente todas ocorrem em cada organização pesquisada. $\mathrm{O}$ autor categorizou o conjunto de práticas e denominou-o de chaves para o comprometimento. São eles: 1) valores people-first (as pessoas em primeiro lugar); 2) diálogos de mão dupla; 3) comunhão; 4) mediação transcendental; 5) contratação baseada em valor; 6) segurança; 7) recompensas extrínsecas palpáveis; e 8) realização.

Mishra (2007) analisou a comunicação em quatro empresas, a partir da percepção de empregados e executivos, que usam várias formas de comunicação entre elas a comunicação face-a-face, comunicação escrita e comunicação digital para construir relacionamentos com seus empregados. A autora concluiu que a comunicação interna é importante para o desenvolvimento do comprometimento dos empregados.

Varona (2002) estudando conceituações de funcionários e supervisores de comprometimento organizacional e satisfação de comunicação e analisando também diferenças e semelhanças dos participantes de estratégias de gestão com base nos níveis de comprometimento em três organizações da Guatemala chegou a seguintes conclusões: i) os funcionários e supervisores foram muitos semelhantes em suas conceituações de comprometimento organizacional e satisfação de comunicação; ii) a satisfação de comunicação foi concebida como um constructo multidimensional com duas dimensões importantes; qualidade de relacionamento entre colegas de trabalho e entre trabalhadores e supervisores; iii) o compromisso da organização concebida como um constructo multidimensional, com a identificação com a missão da organização e ética do trabalho como dois fatores mais importantes. 
De acordo com Sudhaker e Sujit (2006) apud Mishra (2007) muitos são as pesquisas que discutem engajamento de empregados como resultado de esforço da comunicação interna. Notase que mesmo autores que nos seus estudos não tiveram como objetivo principal verificar a relação entre comunicação e comprometimento, ressaltam a importância daquela no desenvolvimento do comprometimento.

Shaw apud Mishra (2007) asseveram que práticas de gestão de pessoas nas empresas em todo o mundo conduzem empregados ao engajamento com os objetivos organizacionais de suas respectivas organizações. Na mesma linha, Carrière e Bourque (2008) ao trazer mais insight na relação entre práticas de comunicação interna, satisfação no trabalho; satisfação com a comunicação e comprometimento organizacional, identificam relações significantes e positivos entre práticas de comunicação interna e satisfação no trabalho, satisfação da comunicação e comprometimento organizacional afetivo. Concordando, Proctor e Doukakis; Kitchen e Daly apud Carrière e Bourque (2008) apontam que a atitude do empregado e resultados de iniciativa de mudanças organizacionais dependem, pelo menos em parte de práticas efetivas de comunicação interna.

SamGnanakkan (2010), Tomlinson (2010) assim como Alexander et al, (2009) nos seus estudos destacam também a comunicação interna entre as práticas de gestão de pessoas que influenciam o comprometimento organizacional.

Portanto, num ambiente em que o perfil do trabalho implica em envolvimento do trabalhador a fim de que tome iniciativas do tipo controle da qualidade, identificação de defeitos, participação em grupos de melhoria e outras formas de ação que requerem disposição para participar, ressalta-se a questão do comprometimento. Na busca de princípios e práticas de gestão de pessoas que contemplam esta nova exigência, a comunicação interna vem paulatinamente, no Brasil e no mundo, conquistando espaços. As organizações modernas estão atribuindo à comunicação organizacional uma importância cada vez maior.

A participação efetiva exige informações. Para participar, o empregado necessita de informação para que possa envolver-se e engajar-se. A informação provoca o diálogo, o fazer parte, a interação social. Portanto, a participação do empregado, sua melhor produtividade seu 
comprometimento está cada vez mais relacionado com a comunicação que se efetiva dentro da organização.

Se a organização é uma instituição social, constituída e definida pelos seus papéis e relacionamentos é fundamental a existência de ambientes de trabalho que preservem a satisfação do funcionário e o respeito ao ser humano. Assim, de acordo com Marchiori (2006) quanto maior for o envolvimento do funcionário maior será o seu comprometimento. Ainda de acordo com a autora faz-se necessário criar um ambiente interno no qual informação, conhecimento e competência fluam livremente para que existam comprometimento pessoal e autodesenvolvimento, aspectos que contribuem para um crescimento organizacional.

A partir da revisão teórica dos constructos comunicação interna e comprometimento organizacional, apresenta-se, a seguir o quadro 4 com a relação entre a questão de pesquisa, objetivo e modelo conceitual.

Quadro no 4 - Relação entre questão de pesquisa, objetivo e modelo conceitual do estudo.

\begin{tabular}{|c|c|c|}
\hline Pergunta da pesquisa & Objetivo & Modelo conceitual \\
\hline $\begin{array}{l}\text { Fatores sociodemográficos e } \\
\text { comunicação interna são } \\
\text { associados ao comprometimento? }\end{array}$ & $\begin{array}{l}\text { Verificar fatores associados ao } \\
\text { comprometimento de empregados } \\
\text { do setor de telecomunicações, } \\
\text { telefonia fixa, segundo estruturas de } \\
\text { mercado. }\end{array}$ & $\begin{array}{l}\text { Gestão estratégica de pessoas } \\
\text { (WALTON, 1997; } \\
\text { ALBUQUERQUE, 2002; } \\
\text { LIMONGI-FRANÇA, 2004) } \\
\text { Comunicação interna planejada } \\
\text { (KUNSCH, 2003; MARCHIORI, } \\
\text { 2006; OLIVEIRA; PAULA, 2006). } \\
\text { Comprometimento organizacional } \\
\text { (MEYER; ALLEN, 1991; } \\
\text { MOWDAY et al, 1982) }\end{array}$ \\
\hline
\end{tabular}

A seguir, apresenta-se, a síntese da revisão teórica, conforme a ilustração 1 . 


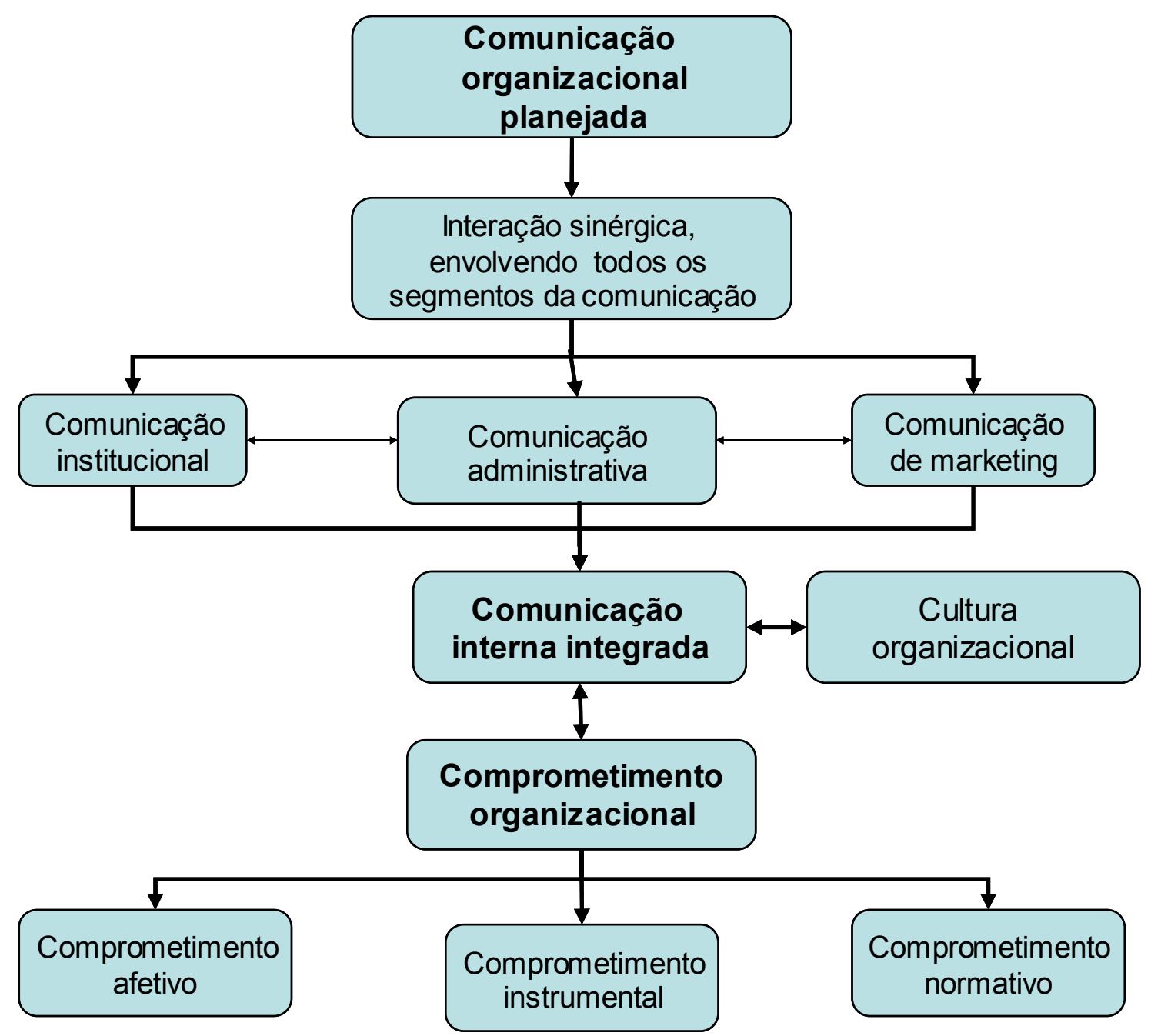

\section{Ilustração 1 - Síntese da revisão da literatura}

Este capítulo permitiu uma investigação dos principais modelos de comunicação interna e comprometimento organizacional o que dará sustentação à investigação empírica cuja metodologia será abordada no capítulo, a seguir. Antes disso, porém, será descrito sumariamente o setor pesquisado, enfatizando as mudanças ocorridas no mesmo. Também será apresentado um breve histórico sobre Cabo Verde, um dos países pesquisado para este estudo. Ainda será caracterizada a empresa estudada com o objetivo de descrever o perfil de cada uma delas. 


\section{CARACTERIZAÇÃO DO SETOR ESTUDADO}


As telecomunicações, compreendidas como transmissão de voz, vídeo e ou dados, usando cabo, fibra ótica ou ondas de rádio, desempenham um papel de suma importância na denominada sociedade da informação e, conseqüentemente, no dia-a-dia das pessoas e organizações. Tradicionalmente, o setor era considerado um monopólio natural ${ }^{3}$, administrado em âmbito público ou privado (PIRES E PICCININI, 1997). Contudo, com a evolução tecnológica e a necessidade de modernização e diversificação dos serviços de telecomunicações, observou-se um movimento mundial de mudanças estruturais legais e políticas. O anexo de Telecomunicações do Acordo Geral de Comércio e Serviços da Organização Mundial do Comércio (OMC) representa um marco neste processo de flexibilização. Esse anexo tem como função orientar o setor por meio de suas regras e princípios, norteando os países às novas tendências internacionais. Assim, cabe às agências reguladoras proporcionarem aos seus respectivos países institutos que adaptem o setor de telecomunicações de acordo com as orientações mundiais do Comércio de Serviços ${ }^{4}$.

Até 1980 a indústria de telecomunicações no mundo era caracterizada por monopólios públicos, em que o Estado detinha grande controle sobre infra-estrutura e serviços em seus países respectivos, entre eles a transmissão de chamadas de voz (local, interurbano e internacional) e fax. Esses monopólios eram integrados com seus fornecedores de equipamentos (AT\&T nos EUA) ou conectados com um grupo de fornecedores cooperativos de equipamentos (NTT) ou ligados por intermédio de uma estrutura bilateral de monopólio (Deutsche Telekom com Siemens e a Telecom da França com Alcatel) (RITA, 2004).

A partir dos anos 1980 ocorreram mudanças nas perspectivas político-institucionais em direção a políticas gerais de cunho neo-liberal que implicaram alterações no modelo dos Estados Unidos e Inglaterra e em menor escala com características diversas no resto da Europa, Japão, América Latina e África. As políticas e formas de regulamentação estiveram voltadas ideologicamente para a quebra dos monopólios nacionais (RITA, op. cit.).

Portanto, pode-se asseverar que as décadas 1980 e 1990 foram caracterizadas por grandes reformas, em países desenvolvidos e em desenvolvimento, na indústria das telecomunicações,

\footnotetext{
${ }^{3}$ Monopólio natural pode ser definida como aquela na qual uma única firma provê o mercado a um menor custo do que qualquer outra situação, dado um determinado nível de demanda, devido ao aproveitamento máximo das economias de escala e de escopo existentes (PIRES; PICCININI, 1997, p. 218).

${ }^{4}$ Disponível em: $<$ htt://www.fd.uc.pt/ci/cee/oi/omc-Anexo_1b.htm>. Acesso em: 12 de abril de 2009
} 
motivados por distintos fatores, tais como: necessidade de atração de investimentos capazes de conduzir à modernização, diversificação e melhoria da qualidade dos serviços, culminando em mudanças estruturais legais e políticas, tais como:

* Privatização das empresas e desregulamentação dos mercados nos EUA e na Europa;

* Mudança da condição dessas empresas que deixaram de ser prestadores de telecomunicações e fornecedores de equipamentos, assumindo uma relação mais específica com a cadeia e com a indústria de software, hardware, semicondutores, internet e e-commerce.

Nos Estados Unidos, as companhias já eram privadas, sob forma de monopólio AT\&T. O processo de reestruturação das telecomunicações iniciou-se efetivamente nos anos 70 e 80 do século XX. Em 1984, foi quebrado o monopólio absoluto da AT\&T no setor de telefonia fixa, com a divisão do país em sete áreas, criando-se monopólios regionais explorados pelas chamadas Baby Bells. À AT\&T foi destinado, em forma de competição, o mercado de chamadas de longa distância inter-regionais e internacionais (RITA, 2004). Contudo, a conclusão do esforço de modernização na infra-estrutura e a liberalização ampla do mercado, com a diminuição das restrições à propriedade cruzada, foi alcançada em 1996 com o novo Estatuto de Telecomunicações.

Os EUA, maior mercado de telecomunicações na atualidade ${ }^{5}$, concentra grande tradição de regulação tradicional de monopólios naturais privados. A Lei de Telecomunicações implantada em 1996 buscou harmonizar, no espaço nacional, os princípios definidos pelo Acordo Geral de Comércio e Serviços para a liberalização dos serviços de Telecomunicações e constitui um referencial em termos internacionais.

$\mathrm{Na}$ Europa, a privatização se deu por meio da liberação dos mercados, com exceção da Inglaterra (British Telecom), acompanhada da abertura do capital das operadoras estatais na bolsa de valores e estabelecendo a intervenção do Estado por meio da regulamentação (RITA, 2004). A

\footnotetext{
${ }^{5}$ Disponível em: $<$ http://www.oragoo.net/quais-sao-as-maiores-empresas-de-telecomunicacoes-domundo $>$. Acesso em: 12 de abril de 2009
} 
União Européia (UE), segundo maior mercado de telecomunicações do mundo ${ }^{6}$, apresentava até recentemente um contexto de forte tradição monopólica estatal no fornecimento de serviços, interrompido pelos recentes esforços de liberalização dos mercados e uniformização das políticas regulatórias. Em resposta ao aprofundamento do processo global de integração econômica e de adoção de alianças estratégicas e joint ventures entre os operadores, a UE vem implementando um conjunto de propostas para a uniformização e a liberalização desse mercado. O objetivo da UE, ao mesmo tempo em que busca uniformizar suas políticas regulatórias com a orientação da OMC para o mercado de serviços, é viabilizar ganhos de economias de escala, eficiência econômica e redução dos preços dos serviços. A ênfase da UE tem sido a de liberalização de mercados, com a remoção das barreiras monopólicas.

Na América Latina, a privatização em geral teve como modelo predominante a compra das estatais locais pelas grandes operadoras da Europa, sob forma de grupos e consórcios, incluindo também a garantia de mercado por determinado tempo e definição de normas para investimentos.

O marco fundamental da reestruturação foi a transformação do monopólio público, provedor de serviços de telecomunicações, em um novo sistema de concessão pública a operadores privados, fundamentado na competição e orientado para o crescimento da universalização dos serviços.

No Brasil, este processo começou em 1995 e culminou em 1998 com a abertura do monopólio estatal ao investimento privado. A Lei Geral de Telecomunicações de 1997 estabeleceu o modelo de reestruturação das telecomunicações e criou a Agência Nacional de Telecomunicações (ANATEL), nos moldes da Federal Communications Comission (FCC) dos Estados Unidos da América (VENTURA, 2001).

A reestruturação do modelo de monopólio estatal das telecomunicações no Brasil acompanhou o movimento de reformas já realizadas em outros países latino-americanos como o México, Chile, Argentina e Venezuela. Até então, o setor de telecomunicações no Brasil tinha como característica marcante o elevado grau de interdependência entre o segmento privado e os

\footnotetext{
${ }^{6}$ Disponível em: <http://www.oragoo.net/quais-sao-as-maiores-empresas-de-telecomunicacoes-do-mundo $>$. Acesso em: 25 de maio de 2009
} 
órgãos governamentais para atendimento às diretrizes referentes aos serviços prestados à comunidade. Adotou-se, neste país, uma política monopolista calcada no modelo da Europa, onde a exploração dos serviços de telefonia estava a cargo de organismos controlados direta ou indiretamente pelo Estado. O movimento de mudanças, no Brasil, consolidou-se com a criação da ANATEL, responsável pela implementação do modelo de flexibilização das telecomunicações no país (PIRES, 1999).

À semelhança da América Latina em alguns países africanos, nomeadamente Cabo Verde, os monopólios estatais foram transferidos para proprietários privados por decreto do poder executivo, sem legislação, órgão regulador, nem normas prévias ou análise de políticas públicas setoriais, o que se configurou em monopólios privados. Foram concedidos longos períodos de exploração exclusiva e só em seguida as autoridades se preocuparam com a regulação do setor.

Cabo Verde possuía a infra-estrutura de telecomunicações administrada pelo Governo. Até 1995 todos os serviços de telecomunicações eram oferecidos pelos Correios, Telégrafos e Telefones (CTT) quando o governo decidiu dividi-lo em duas novas empresas autônomas: empresa de telecomunicações SARL e Correios de Cabo Verde SARL ${ }^{7}$

Com o panorama apresentado, verifica-se que o setor de telecomunicação no mundo tem crescido muito e também passado por diversas reestruturações econômicas e jurídicas. Essas mudanças ocorreram principalmente por causa da privatização, pois o Estado transferiu, para empresas privadas, a propriedade das empresas estatais, sendo estas responsáveis pela prestação dos serviços nos dias atuais. Como conseqüência aumentou a oferta dos serviços; foram criadas oportunidades de investimento e desenvolvimento tecnológico e industrial em ambiente competitivo; acesso à tecnologia mais atual pela população; criação de órgãos reguladores do setor. Mesmo nos países em desenvolvimento, caso do Brasil e Cabo Verde, em que o serviço era prestado exclusivamente pelos governos ou por empresas estatais, verifica-se que o setor vem crescendo, o serviço deixar de ser oferecido pelo estado para ser privatizado, liberalizado e universalizado.

\footnotetext{
${ }^{7}$ Disponível em: $<$ http://www.nave.cv/cvtelecom>. Acesso em: 22 de outubro de 2008
} 
Em ambos os casos, Brasil e Cabo Verde, a partir da década de 90, com a implantação da política de abertura de mercado, a competitividade está se acelerando no setor de teleinformática na busca de atingir um mercado consumidor extenso. Nos últimos anos, com a justificativa de modernizar o setor, os governos dos respectivos países passaram a adotar uma política calcada nos modelos dos Estados Unidos e Canadá, caracterizada por uma estrutura privada de prestação de serviços de telefonia, porém regulamentada pelo Estado.

Verifica-se que a substituição do Estado pela iniciativa privada, na operação dos setores de telecomunicações, nomeadamente telefonia fixa e móvel exigiu o desenvolvimento de marcos regulatórios para garantir os investimentos necessários, promover o bem-estar dos consumidores e usuários e aumentar a eficiência econômica. No Brasil temos a ANATEL e em Cabo Verde a Agência Nacional das Comunicações (ANAC).

\subsection{Breve histórico de Cabo Verde}

Antes de apresentar a caracterização das empresas estudadas, considera-se importante expor brevemente a história de Cabo Verde, o que pode facilitar a compreensão do modelo de gestão adotado pela empresa A.

Cabo Verde é um arquipélago composto por 10 ilhas, conforme o mapa a seguir, sendo nove das quais habitadas, com $4.033 \mathrm{Km}^{2}$ de superfície e situado no oceano atlântico a aproximadamente $650 \mathrm{Km}$ da costa oeste do Senegal. Geograficamente, o arquipélago está dividido em dois grupos: Barlavento e Sotavento, de acordo com os ventos dominantes. Administrativamente o país está dividido em 17 concelhos. De acordo com os dados do Censo 2000, a população residente é de 434.625 habitantes (INE, 2000; 2002). 


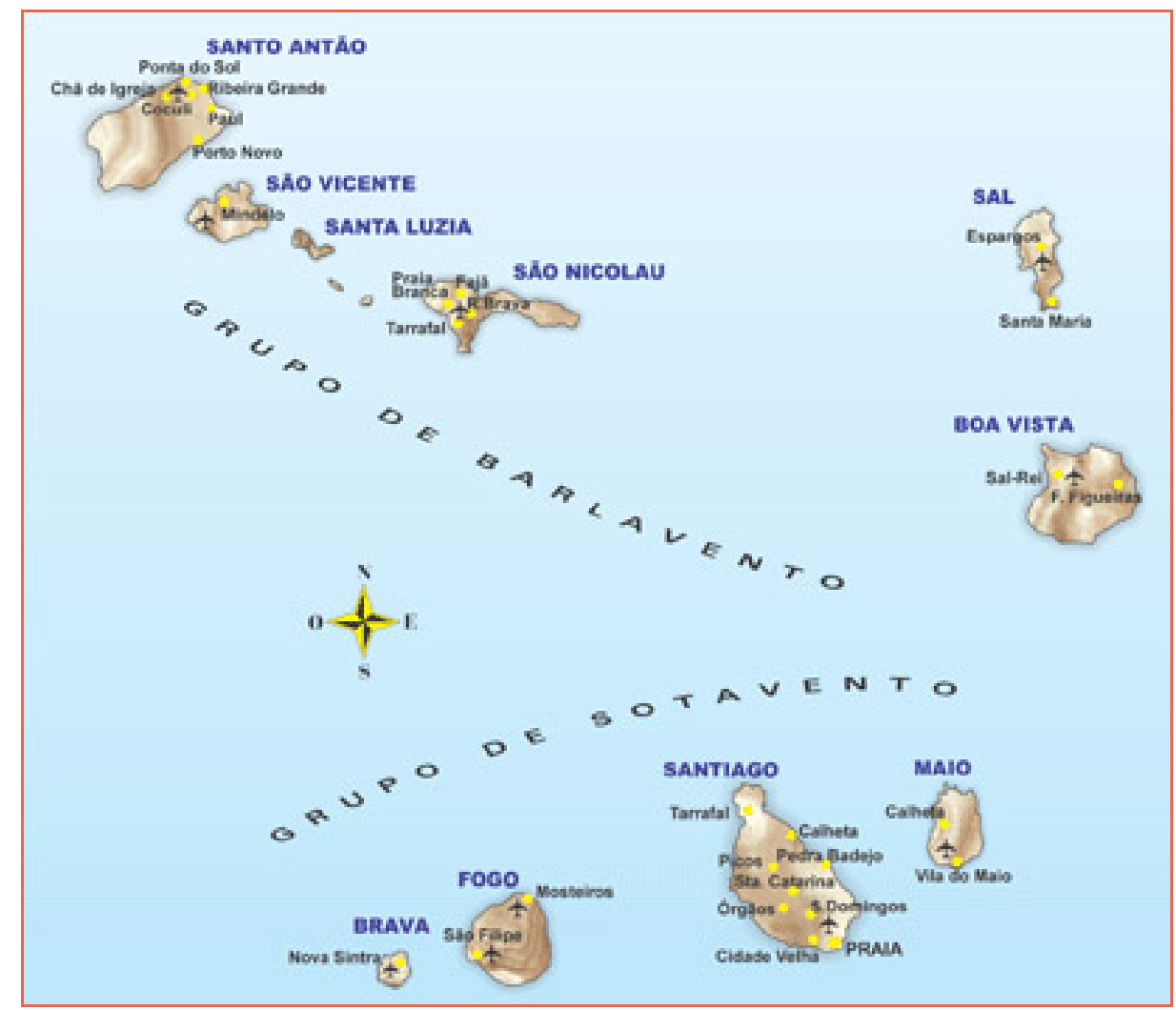

\section{ILUSTRAÇÃO 2 - Mapa de Cabo Verde}

Fonte: http://www.guiadelmundo.com/paises/cape_verde_islands/mapa.html

O país foi colônia portuguesa por cinco séculos. Logo após a sua independência em 1975, conheceu um regime político de partido único até 1990. Em Fevereiro deste ano, alterou-se a Constituição da República, abrindo caminho ao sistema multipartidário, tendo conhecido mudanças em termos de democratização, alternância política, exercício da cidadania, liberalização da economia, legislação, descentralização, entre outros.

Portanto, desde 1991, Cabo Verde tem assistido uma economia em transição na seqüência da adoção, por parte do governo, de uma estratégia de crescimento assente de economia de mercado com redução gradual da intervenção estatal enquanto agente econômico direto substituído pela iniciativa privada, num modelo de abertura ao investimento externo e de inserção na economia mundial.

A partir de 2001, o Governo de Cabo Verde lançou um programa de estabilização macro - econômica apoiado por um programa "Staff-Monitored Program" do Fundo Monetário 
Internacional (FMI), com particular ênfase no melhoramento da gestão orçamental, na contabilidade pública e no controle financeiro. É neste contexto que um vasto programa de privatizações de empresas públicas foi lançado em 1998. O referido programa assenta-se num acordo de "stand by" do FMI e sobre um Trust Fund financiado com fundos provenientes das receitas das privatizações e dos principais parceiros bilaterais (A CONTRIBUIÇÃO DO QUADRO INTEGRADO NA TRANSFORMAÇÃO ECONÓMICA DE CABO VERDE, $\mathbf{2 0 0 8}^{8}$. Deste modo, deu-se a privatização de setores de monopólio natural como, por exemplo, o setor de telecomunicações, energia e água entre outros.

Ainda em 1995, inicia-se a privatização da empresa de serviços de telecomunicações e o Governo autorizou a venda de até $65 \%$ das ações da mesma. Na seqüência do concurso público, a Portugal Telecom adquiriu 40\% das ações. Em finais de 1996, o Governo iniciou a negociação do contrato de concessão. Ainda nesse ano outras ações foram vendidas a privados cabo-verdianos, incluindo trabalhadores da própria empresa de telecomunicações e emigrantes cabo-verdianos residentes no estrangeiro. Atualmente, $58.7 \%$ da empresa pertence a interesses privados e o capital encontra-se dividido da seguinte forma: Portugal Telecom Ventures SGPS (40\%), Instituto Nacional de Previdência Social (37.9\%), Sonangol (5\%), Trabalhadores da empresa e CCV (5\%) e o Estado de Cabo Verde (3.4\%)

O regime básico do estabelecimento, gestão e exploração das infra-estruturas e serviços de comunicações está contido no Decreto-Lei ${ }^{0} 5 / 94$ de 7 de Fevereiro ${ }^{10}$ que determina que "o serviço público de comunicações será explorado em regime exclusivo, pelo Estado, por pessoa coletiva de direito público ou por pessoa coletiva de direito privado, mediante contrato de concessão de serviço".

\footnotetext{
${ }^{8}$ Disponível em: www.integratedframework.org/.../CapeVerde_Concept\%20Note_2008_port.pdf $>$. Acesso em: 26 de outubro de 2008

${ }^{9}$ Disponível em: $<\mathrm{http}: / /$ www.nave.cv/cvtelecom>. Acesso em: 20 de Setembro de 2009.

10 Disponível em: <http://www.anac.cv/docs/st/DLei\%205_94\%20Lei\%20de\%20Base.pdf $>$. Acesso em: 22 de Setembro de 2009.
} 
Pelo Decreto-Lei $\mathrm{n}^{\mathrm{o}} 72 / 95^{11}$ são definidas as regras regulamentadoras do regime do estabelecimento, gestão e exploração das infra-estruturas e da prestação de serviços de telecomunicações complementares.

O acesso é feito pela atribuição de licença pelo membro do Governo responsável pela área das telecomunicações, com a condição de verificação dos requisitos constantes no diploma e sempre precedido de concurso público. É assim que o contrato de concessão concede à empresa de telecomunicação um regime de exclusividade, por um período de 25 anos, com possibilidades de renovações sucessivas por períodos mínimos de 15 anos.

\subsection{Caracterização das empresas estudadas}

\subsection{1 - Empresa A: Telefonia Fixa em Cabo Verde}

Apesar da crescente liberalização do setor das telecomunicações por toda parte do globo, existe em Cabo Verde um único operador de serviços de telecomunicações, com exclusividade dos serviços básicos da telefonia fixa: a empresa $\mathrm{A}$, decorrente do contrato de concessão de exploração da rede fixa.

Preparando o lançamento do serviço de Televisão por Assinatura e o aparecimento de novos operadores de Internet e Telefonia Móvel em 2007 a empresa A deu origem a três empresas: a própria empresa Alfa, gestora da rede e do negócio de telefonia fixa; a CVMóvel, que explora a rede móvel, e a CVMultimédia que se dedica às ligações via Internet e à Televisão por Assinatura.

A empresa tem sede na cidade da Praia, ilha de Santiago, com uma Coordenação Local no Interior da Ilha de Santiago para cobrir o interior da ilha; duas Coordenações Locais nas ilhas de Fogo e Brava e Sal e Boavista e uma Coordenação Regional Norte que compreende as outras ilhas.

\footnotetext{
${ }^{11}$ Disponível em: <http://www.anac.cv/docs/st/DLei72-95.pdf>. Acesso em: 15 de Setembro de 2009.
} 
A empresa tem faturamento anual de 4.450 milhões de escudos cabo-verdianos; um total de 408 colaboradores, sendo 16,4\%, com formação superior; $11,0 \%$ com formação médio; 57,6\% técnicos operacionais e $15,0 \%$ profissionais de apoio ${ }^{12}$.

A empresa define como visão ser uma empresa de comunicações, tecnologicamente avançada, rentável, orientada para o serviço ao cliente e socialmente responsável e como missão prestar, com qualidade, serviços de comunicações, no sentido de satisfazer as necessidades dos clientes, proporcionar mais-valias aos acionistas e contribuir para o desenvolvimento global e sustentado da sociedade cabo-verdiana.

Com os 10 anos de existência como empresa privatizada, a empresa expandiu a rede fixa por todos os cantos do país, passando de 21 mil para 72 mil clientes, o que significa que o número de telefones aumentou em 250\%. Para a expansão da rede, que é obrigação da empresa, de acordo com a concessão, foram investidos mais de 100 milhões de dólares (DADOS DA PESQUISA).

\subsection{2 - Empresa B: Telefonia Fixa no Brasil}

A empresa pertence a um Grupo da telefonia fixa e é um dos três maiores conglomerados de telecomunicações do mundo, pelo critério de número de clientes: são mais de 228 milhões de acessos de clientes nos 24 países em que está presente nas regiões da América Latina, Espanha e outros países da Europa. Opera no Estado de São Paulo, desde 1998, com 12 milhões de linhas fixas e 2,1 milhões de acessos Speedy. Atua em todo o Brasil para chamadas nacionais e internacionais. Lidera o mercado nacional de internet em banda larga, com o Speedy. Tem cerca de 6000 funcionários. A receita operacional líquida da empresa em 2008 atingiu R $\$ 23$ bilhões de reais e um investimento de quase 3 bilhões no ano (DADOS DA PESQUISA) .

A empresa tem como principais clientes, Voz e dados Estado de São Paulo e Prefeitura de São Paulo e TV Pessoa física. A sua participação no mercado está distribuída da seguinte forma: Voz, 79\% de market Share; Dados, 56\% e TV, $20 \%$.

${ }^{12}$ Disponível em: <http://www.nave.cv/cvtelecom>. Acesso em: 20 de Setembro de 2009. 
A empresa oferece entre outras, Linhas telefônicas fixas, Planos Meus Minutos, Speedy, Internet Ilimitada, TVA Extreme, serviços digitais como Detecta, Secretária Eletrônica Digital e Discagem Abreviada, planos para chamadas de longa distância, a linha da economia família, as linhas controle e planos alternativos em minutos com descontos em função do volume contratado; produtos e serviços específicos para profissionais e negócios, tais como Posto Informático, Speedy Negócios, Vox Fácil; Produtos e serviços específicos para grandes empresas, como, por exemplo, VPN Corporate, Flexmídia e Posto de Trabalho (DADOS DA PESQUISA).

Atualmente cerca de 5 milhões de clientes residenciais da empresa B e mais de 860 mil assinantes empresariais já aderiram a uma dessas opções, o que representa praticamente a metade dos 12 milhões de assinantes da empresa no Estado de São Paulo (DADOS DA PESQUISA).

A empresa tem como visão melhorar a vida das pessoas, facilitar o desenvolvimento dos negócios e contribuir para o progresso das comunidades em que atua, proporcionando-lhes serviços inovadores com base nas Tecnologias da Informação e Comunicação. Para cada stakeholder a empresa estabelece missões: a) Empregados: oferecer aos nossos profissionais o melhor lugar para trabalhar, atraindo e retendo talentos, e garantir as melhores oportunidades de desenvolvimento pessoal; b) Clientes: pôr as necessidades do cliente no centro de tudo que fazemos, para obter sua satisfação máxima com nossos serviços e soluções; c) Acionistas: proporcionar aos nossos acionistas a melhor combinação de crescimento e rentabilidade do setor; d) Sociedade: atuar como um importante agente de desenvolvimento tecnológico, econômico e social nas comunidades onde estamos presentes, combinando nossa ambição de ser global e eficiente, com a vocação de satisfazer os requisitos de cada mercado local. Em relação aos valores, a empresa trabalha continuamente para ser um Grupo Inovador, Competitivo e Aberto (DADOS DA PESQUISA).

A seguir, a ilustração 3 com o mapa do Brasil, incluindo todas as regiões em que a empresa B atua, prestando serviços. 


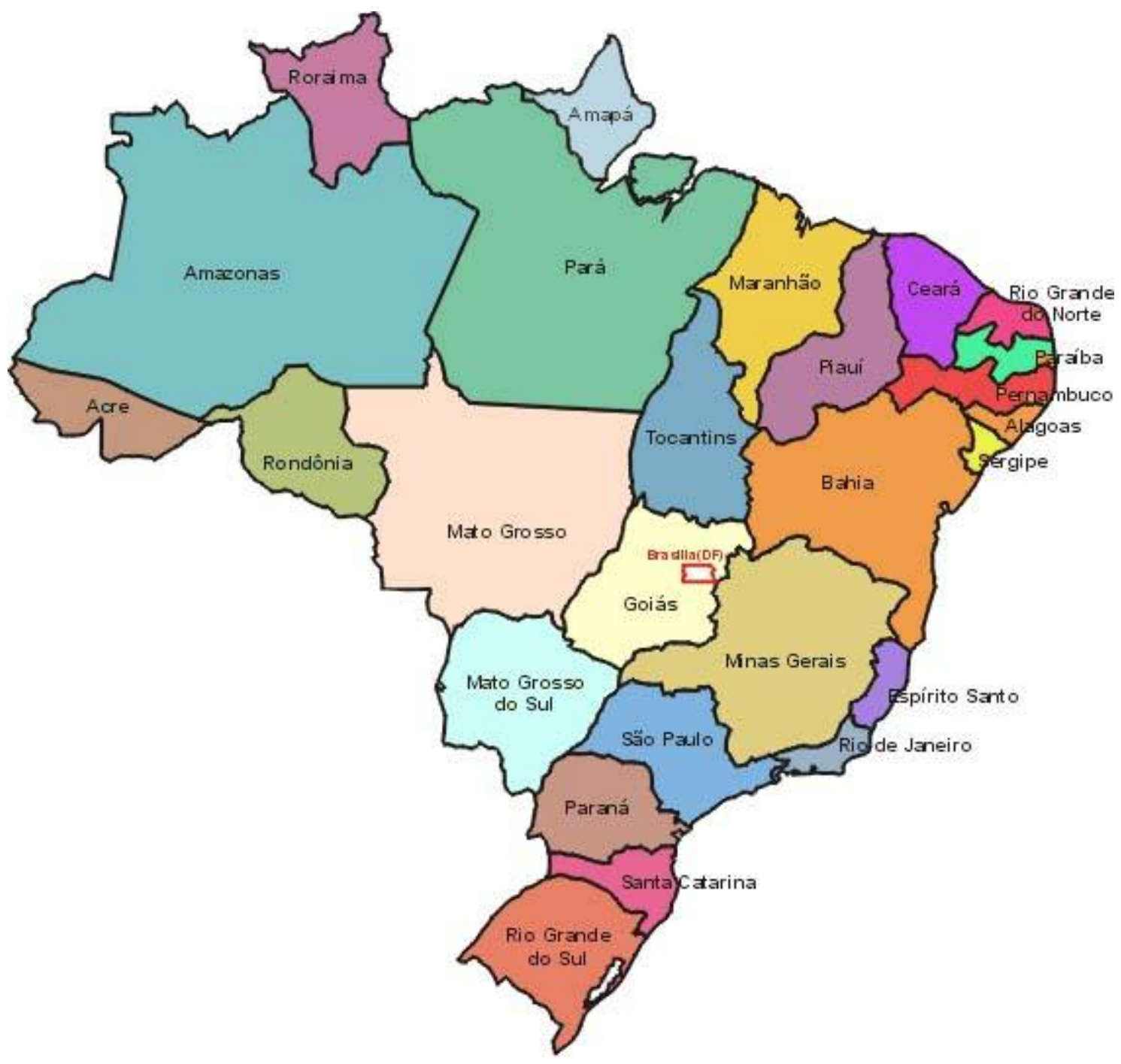

\section{ILUSTRAÇÃO 3 - Mapa do Brasil}

Fonte: http://www.guiadelmundo.com/paises/brasil/mapa.html 


\section{MÉTODOS E INSTRUMENTOS DA PESQUISA DE CAMPO}


Este capítulo expõe a metodologia utilizada nesta pesquisa, metodologia esta sustentada pelo referencial teórico desenvolvido no capítulo 2. Assim, de acordo com o objetivo deste estudo foram definidos os objetivos e questões de pesquisa; as etapas do processo de pesquisa; o tipo de pesquisa; a população e a amostra; o instrumento de coleta de dados e as técnicas estatísticas de análise dos dados.

\section{1 - Objetivo e questão de pesquisa}

Este estudo tem o objetivo, como já exposto na seção 1.2, no capítulo de introdução, verificar fatores associados ao comprometimento de colaboradores do setor de telecomunicações, telefonia fixa, segundo estruturas de mercado.

Partindo-se do referencial teórico apresentado foi proposta a seguinte questão de pesquisa: Fatores sociodemográficos e comunicação interna são associados ao comprometimento?

Esta questão central de pesquisa nos leva a levantar três hipóteses orientadoras do estudo. Elas já foram apresentadas na seção 1.3 do capítulo introdução e estão sendo retomadas, a seguir:

* $\mathrm{H}_{1 \mathrm{~A}}$ : Variável comunicação interna influencia no comprometimento organizacional.

* $\mathrm{H}_{1 \mathrm{~B}}$ : Variáveis sociodemográficas influenciam o comprometimento organizacional.

$\mathrm{H}_{1 \mathrm{C}}$ : Variáveis sociodemográficas são moderadoras no estudo de associação entre variáveis comunicação interna e comprometimento.

* $\mathrm{H}_{1 \mathrm{D}}$ : Variável comunicação interna é moderadora no estudo de associação entre variáveis sociodemográficas e comprometimento.

\section{2 - Etapas do processo de pesquisa}

Segundo Hair Jr. et al, (2005b) o processo padrão para operacionalização de pesquisas em administração pode ser resumido da seguinte forma: 


\section{Fase I - Formulação}

Desenvolver teorias

Questões de pesquisa

Hipóteses

Plano de estudo
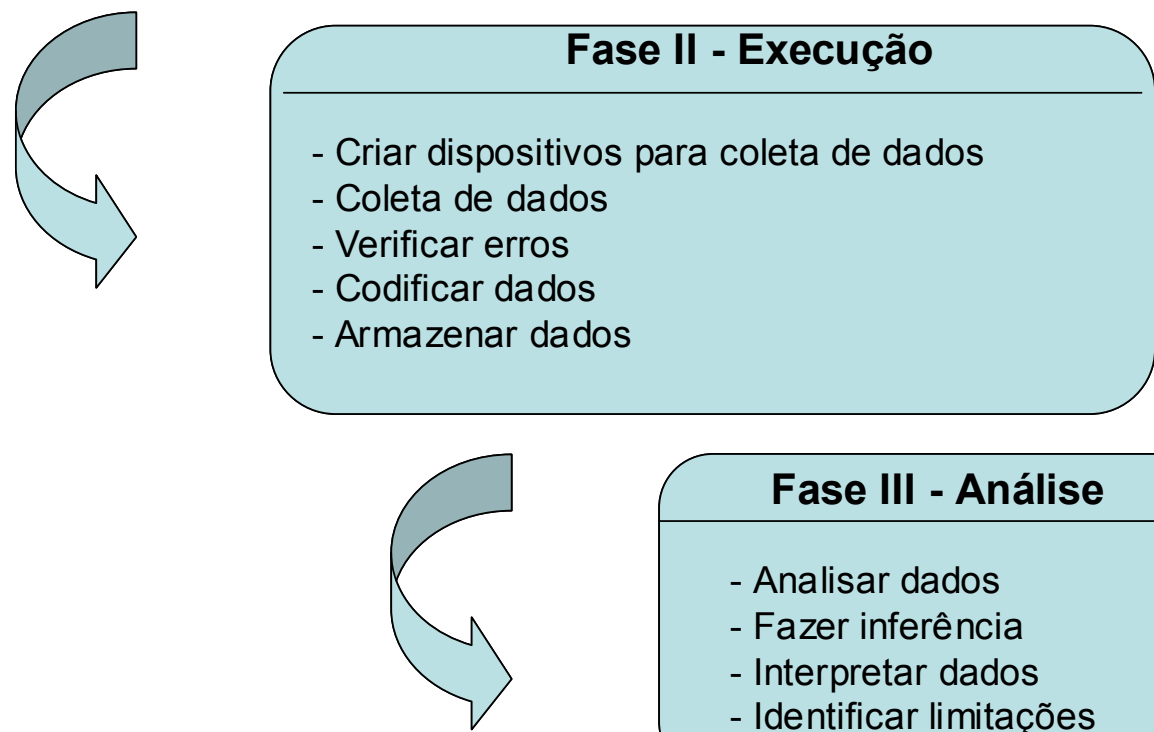

Fase III - Análise

- Analisar dados

- Fazer inferência

- Interpretar dados

- Identificar limitações

Ilustração 4 - Processo de pesquisa em Administração

FONTE: HAIR Jr. et al, (2005b, p. 76).

Na fase I, conforme a ilustração 4, a revisão da literatura forneceu subsídios para o entendimento das peculiaridades dos novos paradigmas nas práticas de gestão para a formulação do modelo de pesquisa proposto. Foram explorados conceitos sobre comunicação organizacional e comprometimento organizacional e as possíveis relações entre eles.

A fase II da ilustração será descrita neste capítulo. Será explicado ao longo das sessões o procedimento metodológico desenvolvido na pesquisa de campo. Será detalhada a pesquisa planejada para o estudo (seções 4.2; 4.3 e 4.4). Em seguida são apresentados os dois tipos de pesquisas que compõem o estudo (seções 4.4.1 e 4.4.2), os critérios de definição da população e amostra (seção 4.5); o protocolo de estudo (seção 4.6) e o instrumento de coleta de dados, forma de abordagem e o pré-teste (seção 4.7 e 4.7.1); e as variáveis de estudo (seção 4.8, 4.8.1 e 4.8.2). Por último, apresenta-se o procedimento para análise dos resultados (seção 4.9). 


\section{3 - Tipo de pesquisa}

Os projetos de investigação podem ser agrupados em várias classes. Muitas são as propostas encontradas na literatura para classificar os diversos métodos de pesquisa disponíveis (KERLINGER, 1980; SELLTIZ et al, 2005; KINNEAR; TAYLOR, 1996; GIL, 2002). As várias classificações são, no entanto, complementares, na medida em que adotam critérios para a caracterização das diferentes abordagens metodológicas de pesquisa, enfatizando aspectos diversificados e complementares. Assim, as pesquisas podem ser agrupadas em três grandes grupos: exploratórios, descritivos e causais (HAIR et al, 2005a; SELLTIZ et al, 2005; MALHOTRA, 2006), sendo este último denominado por Gil (2002, p. 43) de pesquisa explicativa.

As pesquisas exploratórias têm como principal foco a descoberta de idéias e intuições e são recomendadas quando o pesquisador quer se familiarizar com o fenômeno a ser estudado, chegar a uma nova compreensão do mesmo, melhor definir e formular um problema de pesquisa, criar novas hipóteses ou quando se trata de um campo de estudo relativamente novo. Estes estudos são bastante valiosos, pois permitem novos insights sobre um determinado assunto. Porém, são limitados em termos de capacidade de predição uma vez que costumam ser realizados com pequenas amostras, sem que haja preocupação de representatividade (MALHOTRA, 2006).

As pesquisas exploratórias são estudos empíricos que desenvolvem hipóteses e formulam questões, tendo como um de seus objetivos modificar e clarificar conceitos (LAKATOS; MARCONI, 1990).

Malhotra (2006) também define as pesquisas exploratória, descritiva e causal como as classificações fundamentais de concepções de pesquisa e que estas podem ser combinadas de acordo com a natureza do problema. Porém, o autor considera que estudos descritivos e causais podem ser entendidos como conclusivos, conforme ilustrado na figura a seguir: 


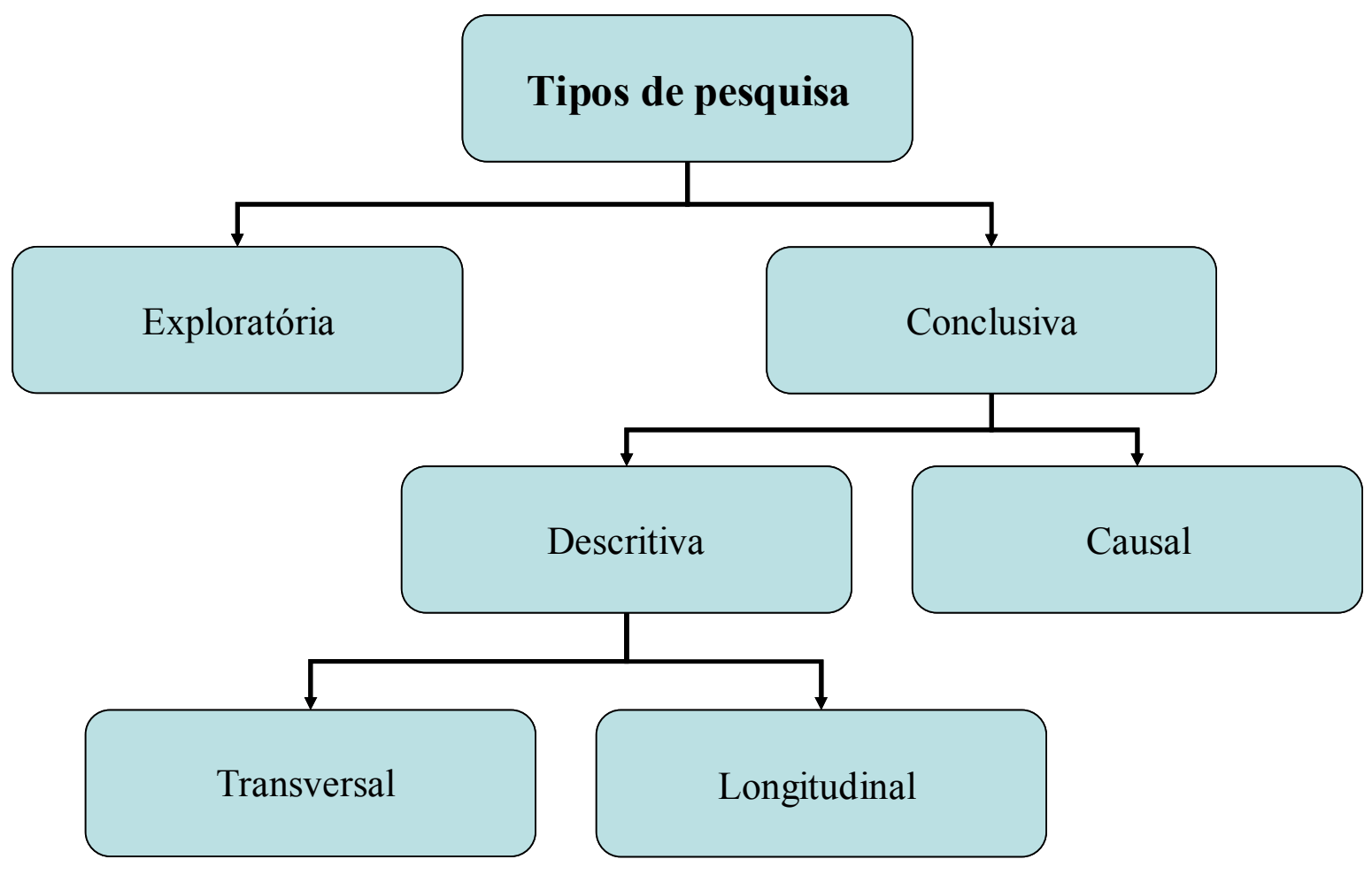

Ilustração 5 - Tipos de pesquisa

Fonte: adaptado de MALHOTRA (2006, p. 105).

Os estudos descritivos têm como preocupação buscar a maior exatidão possível, com um mínimo de viés. Neste caso, os objetivos podem ser a apresentação precisa de características de uma situação, um grupo ou um indivíduo específico (com ou sem hipóteses específicas iniciais) ou a verificação da freqüência com que algo ocorre ou com que está ligado. De acordo com Gil (2002) este tipo de estudo tem como objetivo primordial a descrição das características de determinada população ou fenômeno ou, então, o estabelecimento de relações entre as variáveis.

Diferentemente do que ocorre nas pesquisas exploratórias, nas pesquisas descritivas a elaboração das questões de pesquisa pressupõe profundo conhecimento do problema a ser estudado. O pesquisador precisa saber exatamente o que pretende com a pesquisa, ou seja, quem ou o que se deseja medir, quando e onde o fará, como fará e porque deverá fazê-lo (KINNEAR; TAYLOR, 1996).

A partir de pesquisa descritiva é possível expor características de um certo fenômeno em estudo, mas sem intenção ou responsabilidade de explicá-las (VIEIRA, 2002). A pesquisa descritiva é insuficiente para inferir a presença ou causa e efeito num determinado 
relacionamento. Parasuraman (1991) ressalva a possibilidade de haver áreas cinzas entre os estudos descritivos e causais, pois uma pesquisa pode ter características de uma e outra abordagem.

Já com as pesquisas do tipo causal busca-se também a maior precisão, mas permitindo a verificação de uma hipótese de relação causal entre as variáveis. Este tipo de pesquisa é o que mais aprofunda o conhecimento da realidade e tem como preocupação central identificar os fatores que determinam ou que contribuem para a ocorrência de fenômenos. Aaker et al (1995) explicam que as pesquisas causais devem ser utilizadas quando é preciso mostrar que uma variável causou ou determinou efeito na outra.

$\mathrm{Na}$ prática, esses diferentes tipos de estudos nem sempre são nitidamente separáveis, o que ocorre é uma acentuação de um ou outro tipo. Nas ciências aplicadas em geral os estudos são exploratórios, pois toda pesquisa traz certo pioneirismo (SELLTIZ et al, 2005).

Pode-se observar que os estudos agrupados na primeira classificação correspondem à categoria de estudos exploratórios, pois sua principal ênfase refere-se à descoberta de idéias e intuições. Os estudos classificados nos tipos descritivo e causal têm como consideração fundamental a exatidão. Nesse sentido, estes estudos estão dentro da categoria de estudos descritivos.

Diante das classificações acima e remetendo ao objetivo de investigação deste trabalho, detalhados na seção 4.3, estabelece-se para esta pesquisa o tipo exploratório, descritivo ou de associação entre variáveis. Definiu-se como uma pesquisa exploratória:

* Pelo fato desta ser uma pesquisa no campo social, para a qual raramente se estabelece a relação de causalidade, devido à dificuldade de isolar o efeito de todas as variáveis não envolvidas no estudo e que poderiam afetar o resultado da variável dependente;

* Por estudar uma situação existente, com base em possibilidades reais de verificação, entende-se que o presente trabalho enquadra-se no primeiro objetivo apontado por Selltiz et al (2005), isto é, familiarizar-se com o fenômeno; 
* E, por outro lado, porque embora a amplitude da pesquisa qualitativa exploratória seja pequena, a profundidade desse tipo de pesquisa é grande, ou seja, ocorre a centralização em menos casos ou características, mas cada alvo do estudo tem os detalhes analisados; e descritiva ou associação entre variáveis pelo fato de se pretender verificar fatores associados ao comprometimento de empregados do setor de telecomunicações, telefonia fixa, segundo estruturas de mercado.

O estudo restringe-se à coleta e análise de dados em um determinado momento do tempo, caracterizando em perspectiva, um corte transversal único.

Este estudo não pode ser considerado causal porque seriam necessários o controle de variáveis indiretas e a manipulação de uma ou mais variáveis independentes, como experimento (MALHOTRA, 2006).

As informações foram obtidas por meio de um estudo transversal, em que voluntariamente os funcionários de empresas de telecomunicações em Cabo Verde e no Brasil aceitaram participar da pesquisa. Portanto, este estudo se caracteriza como exploratório, descritivo e transversal.

\section{4 - Escolha do método}

A primeira decisão quanto ao método de pesquisa será a de definir o tipo de pesquisa a ser desenvolvido, pois todo planejamento e execução de uma pesquisa têm como subsídio o uso do método, que em pesquisa significa a escolha de procedimentos sistemáticos para a descrição e explicação de fenômenos.

Segundo Gil (2002), uma pesquisa é um processo formal e sistemático de desenvolvimento do método científico, que tem como principal objetivo descobrir respostas para problemas, mediante o emprego de procedimentos científicos. Para o autor (op. cit, p. 17),

A pesquisa é desenvolvida mediante o concurso dos conhecimentos disponíveis e a utilização cuidadosa de métodos, técnicas e outros procedimentos científicos. Na realidade, a pesquisa desenvolve-se ao longo de um processo que envolve inúmeras 
fases, desde a adequada formulação do problema até a satisfatória apresentação dos resultados.

Richardson et al (1999, p. 70) definem o método de pesquisa como "escolha de procedimentos sistemáticos para a descrição e explicação dos fenômenos”. A escolha do método deve ser coerente ao problema investigado.

De acordo com Yin (2005), o estudo de caso é o método aplicável quando se investiga um fenômeno contemporâneo dentro do seu contexto da vida real. Estudos de caso apresentam-se como melhor metodologia quando se trata de estabelecer o "como" e "por que" das perguntas do problema a estudar, mas também servem para os casos em que não se pode ter um bom controle da situação a ser pesquisada, ou quando ela está imersa no contexto da vida real. Por sua vez, Lazzarini (1995, p. 19) constata que: "o estudo de caso é particularmente aplicável quando se deseja obter generalizações analíticas, e não estatísticas, que possam contribuir para um certo referencial teórico".

Realmente, a natureza do problema ou o seu nível de aprofundamento são os fatores que determinam a escolha do método de coleta de dados.

Parasuraman (1991) define estudo de caso como sendo um exame em profundidade de uma unidade de interesse. Simon apud Parasuraman (op. cit., p. 132) descreve o propósito e a natureza do estudo de caso como sendo:

Um método de escolha quando se quer obter uma riqueza de detalhes sobre o objeto de estudo. Provavelmente se quer estes detalhes quando não se sabe exatamente o que se está procurando. Portanto, o estudo de caso é apropriado quando se está tentando descobrir indícios e idéias para outras pesquisas; neste sentido, o estudo de caso serve a um objetivo similar ao da opinião de especialistas, ou seja, também possibilita indícios.

Por outro lado, Kinnear e Taylor (1996) ressaltam que o estudo de caso possui três características: (1) os dados podem ser obtidos com um nível de profundidade, permitindo a caracterização e a explicação detalhada dos aspectos singulares do caso em estudo, (2) a atitude receptiva do pesquisador deve ser caracterizada pela busca de informações e gerações de hipóteses e não por conclusões e verificações e (3) a capacidade do pesquisador de reunir numa interpretação unificada inúmeros aspectos do objeto pesquisado. 
No que se refere à representatividade do estudo de caso, Castro (1977) ainda ressalta que nos estudos de caso as análises, muitas vezes, ficam por conta do julgamento do pesquisador. Portanto, diante de um problema onde o conhecimento é escasso e rudimentar, a escolha por conhecer uma pequena parte do universo, mesmo sem saber se essa parte é representativa do todo é uma opção válida, pois o mais importante é o que o caso sugere a respeito do todo, são sinalizações oriundas desse caso para a possível explicação de eventos contemporâneos ou para pesquisas mais profundas no assunto. Deste modo, as sinalizações poderão ser usadas como base para novas teorias e modelos.

Campomar (1991) aponta que o estudo de caso envolve a análise intensiva de um número relativamente pequeno de situações e, às vezes, o número de casos estudados se reduz a um. A ênfase se dá à descrição de fatores de cada situação, sem se importar com os números de casos envolvidos. Ao falar do estudo intensivo de um único caso, o autor acrescenta que este permite a descoberta de relações que não seriam encontradas de outra forma, sendo as análises e inferências em estudo de casos feitas por analogias de situações, respondendo, principalmente, às questões "como" e "por que".

Em razão das considerações apresentadas anteriormente, pelo tipo de informações e pelo grau de profundidade desejado, para elaboração deste trabalho escolheu-se como estratégia de pesquisa o método de estudo de casos múltiplos, indicado para pesquisas de campo cujo objetivo primordial é investigar um fenômeno ou situação específico, analisando seu contexto e processos ou etapas envolvidas. Optou-se pela realização de dois casos e este método foi escolhido por ser considerado mais adequado ao trabalho em perspectiva pelas seguintes razões:

* Tratar-se de um fenômeno contemporâneo dentro do seu contexto da vida real (YIN, 2005).

* Procurar fazer generalizações analíticas, de forma a contribuir para referenciais teóricos de estudos futuros (LAZARINI, 1995).

Para alcance dos objetivos deste estudo foi realizada uma pesquisa em duas fases (quantitativa e qualitativa) para verificar os fatores associados ao comprometimento de 
funcionários de empresas de telecomunicações. Para ambas as fases, os dados foram coletados de fontes primárias.

\subsection{1 - Pesquisa quantitativa}

Godoy (1995) identifica outra forma de abordagem para classificar as pesquisas, apontando dois tipos de pesquisas: a pesquisa qualitativa e a pesquisa quantitativa. As pesquisas qualitativas não procuram enumerar ou medir os eventos estudados, nem empregam instrumental estatístico na análise de dados como se faz durante uma pesquisa quantitativa. A pesquisa qualitativa parte de questões ou focos de interesses amplos que vão se definindo à medida que $\mathrm{o}$ estudo se desenvolve. Este tipo de abordagem envolve a obtenção de dados descritivos sobre pessoas, lugares e processo interativos, procurando compreender os fenômenos, segundo a perspectiva dos sujeitos, ou seja, dos participantes da situação em estudo.

Por outro lado, Kirk e Miller, apud Colwell (1990, p.15) apresentam a distinção entre pesquisa qualitativa e pesquisa quantitativa asseverando que: “[...] uma observação qualitativa identifica a presença ou ausência de algo, em contraste com a observação quantitativa que envolve o grau em que algo está presente". Dentro do mesmo contexto Gordon e Langmaid, apud Colwell (op. cit., p.15), afirmam que a pesquisa qualitativa se preocupa principalmente com o entendimento das coisas ao invés de medi-las.

Diferente da pesquisa qualitativa, a pesquisa quantitativa caracteriza-se pela utilização predominante de métodos quantitativos, centrando sua preocupação em encontrar os fatos e as causas do fenômeno social sem o uso de interpretação subjetiva.

A abordagem quantitativa deste trabalho teve como objetivo verificar fatores associados ao comprometimento de funcionários de empresas de telecomunicações, valendo-se para tanto do recurso de quantificação e de técnicas de análises estatísticas. Para a referida pesquisa realizou-se um levantamento amostral com os funcionários das empresas estudadas e essa fase possibilitou a resposta à indagação que motivou o presente estudo. Foi desenvolvida com base em questionário estruturado, possibilitando a verificação das hipóteses de estudo. 


\subsection{2 - Pesquisa qualitativa}

As pesquisas qualitativas possibilitam maior profundidade na análise dos dados coletados, contudo com pequena amplitude, sem a propriedade de generalização dos resultados da amostra para a respectiva população. Neste tipo de pesquisa, a centralização ocorre em menos casos ou características. Contudo, cada alvo de estudo tem os detalhes analisados.

Tesch apud Moreira (2002) assevera que a pesquisa qualitativa é aquela em que a informação coletada pelo pesquisador não é expressa em números, ou então os números e conclusões neles baseadas representam um papel menor na análise. Portanto, os dados qualitativos incluem, além de informações expressas nas palavras oral e escrita, também informações expressas como pinturas, fotografias, desenhos, filmes, videoteipes a até mesmo trilha sonora. "Em termos genéricos, a pesquisa qualitativa pode ser associada à coleta e análise de texto (falado e escrito) e à observação direta de componentes” (MOREIRA, op. cit., p. 17).

Richardson et al, (1999) afirmam que a análise qualitativa tem como objeto situações complexas ou estritamente particulares. Os estudos que empregam esta metodologia podem descrever a complexidade de um determinado problema, analisar a interação de certas variáveis, compreender e classificar processos dinâmicos vividos por grupos sociais, contribuir no processo de mudança de determinado grupo e possibilitar, em maior nível de profundidade, o entendimento das particularidades do comportamento dos indivíduos. Para estes autores, os estudos qualitativos devem compreender dados de difícil coleta por outros métodos, ou ainda estudos sobre os quais se dispõe de pouca informação.

As duas grandes vertentes, quantitativa e qualitativa, se diferenciam, sobretudo, por questões metodológicas ligadas ao procedimento de coleta de dados. As técnicas de coleta de dados qualitativas, entre elas a entrevista em profundidade individual ou em grupo, permitem alcançar um maior grau de profundidade dos dados e análise de uma situação. É a natureza do problema ou o seu nível de aprofundamento que, de fato, determina a escolha do método. A abordagem qualitativa de um problema, além de ser uma opção do investigador, justifica-se, sobretudo, por ser uma forma adequada para entender a natureza do fenômeno social (RICHARDSON et al, 1999). 
Outros autores que discorrem sobre o assunto é Hair et al. (2005a), assegurando que os dados quantitativos são mensurações em que números são usados diretamente para representar as propriedades de algo, sendo desta forma propícios à análise estatística, enquanto os dados qualitativos, por sua vez, representam a descrição de coisas sem a atribuição direta de números, ao contrário, os dados são coletados por meio de registro de palavras e por vezes imagens (HAIR et al., 2005a, p. 170).

As abordagens qualitativas para a coleta de dados são freqüentemente usadas no estágio exploratório do processo de pesquisa. Seu papel é identificar e ou refinar os problemas de pesquisa que possam ajudar a formular e testar estruturas conceituais. Por sua vez, as abordagens quantitativas para coleta de dados são muito usadas quando temos problemas de pesquisa ou modelos teóricos bem definidos. A validação desses conceitos e modelos normalmente envolve o uso de dados obtidos em surveys de grande escala.

Um estudo de caso pode não apenas incluir, mas também se limitar a evidências quantitativas, não sendo este tipo de evidência o que diferencia a estratégia de pesquisa. Os estudos de casos podem se basear em qualquer mescla de provas quantitativas e qualitativas (YIN, 2005).

Segundo Maria Reis (1994) a decisão por um estudo qualitativo deve ser tomada segundo alguns critérios, a saber:

* A abrangência do fenômeno: quanto maior a abrangência do que se quer pesquisar, mais adequada é a pesquisa qualitativa, em função das características holísticas, sua orientação para a exploração e descrição dos fenômenos;

* A quantidade de informação disponível: em estudos onde a quantidade de informação é reduzida, é mais conveniente usar pesquisa qualitativa, já que a dificuldade de se usarem medidas controladas é maior;

* A complexidade do fenômeno a ser estudado: quanto mais complexo é o assunto da investigação, maior a necessidade de se obter profundidade nas informações e, de acordo com Maria Reis (1994), isso é melhor obtido por meio da pesquisa qualitativa; 
* O tempo e os recursos disponíveis para a pesquisa: mais adequado é o uso da pesquisa qualitativa quando se tem menor disponibilidade de tempo e recurso, desde que o objetivo da pesquisa seja compreender o fenômeno e não medir a sua ocorrência.

A escolha da abordagem qualitativa justifica-se por esta pesquisa ter como intuito a compreensão do fenômeno estudado, a partir de informações dos funcionários e das pessoas que ocupam cargo de gerência. Para esta abordagem, os dados foram obtidos por intermédio de entrevistas junto ao Diretor de Comunicação e Relações Corporativas e Gerente de Recursos Humanos (Brasil) e Diretora do Gabinete de Comunicação e Imagem; Diretora de Recursos Humanos e Administrador Executivo (Cabo Verde), orientadas por um roteiro de questões. A escolha desses entrevistados foi feita por conveniência e teve como objetivo:

* Levantar informações sobre a percepção das pessoas que ocupam cargo de gerência/ diretoria sobre comunicação e comprometimento e confrontá-las com as informações dadas pelos funcionários na pesquisa quantitativa.

Para tal fim foram aplicados roteiros, explorando as percepções de diretores/ gerentes das empresas pesquisadas. O quadro 5, a seguir, indica os construtos envolvidos na construção do roteiro para a pesquisa qualitativa. 
Quadro $n^{0} 5$ - Roteiro resumido da pesquisa qualitativa

\begin{tabular}{|c|c|}
\hline \multirow[b]{2}{*}{$\begin{array}{c}\text { Parte I } \\
\text { PERFIL DA EMPRESA }\end{array}$} & Pergunta \\
\hline & $\begin{array}{l}\text { 1. Quantos empregados possui a empresa (sede, filiais/ regiões e o grupo } \\
\text { todo) } \\
\text { 2. Qual a participação de mercado da empresa? } \\
\text { 3. Com que finalidade a empresa trabalha com os conceitos de visão, } \\
\text { missão, objetivos e metas? }\end{array}$ \\
\hline $\begin{array}{l}\text { Parte II } \\
\text { PROCESSO DE } \\
\text { SOCIALIZAÇÃO }\end{array}$ & $\begin{array}{l}\text { 4. Quando um novo integrante entra na empresa existe um roteiro para } \\
\text { apresentá-lo a todos? }\end{array}$ \\
\hline \multirow{7}{*}{$\begin{array}{l}\text { Parte III } \\
\text { ASPECTOS SOBRE } \\
\text { COMUNICAÇÃO }\end{array}$} & $\begin{array}{l}\text { 5. A empresa adota uma política de comunicação integrada? Por quê? Se } \\
\text { sim, como se processa? }\end{array}$ \\
\hline & $\begin{array}{l}\text { 6. Na sua opinião a comunicação interna é eficaz? Por quê? } \\
\text { 7. Quais os canais de comunicação da organização que traduzem diretrizes, } \\
\text { inovações, normas e manifestações nos mais variados assuntos? }\end{array}$ \\
\hline & $\begin{array}{l}\text { 8. No seu entender, existe uma preocupação da empresa em fazer com que } \\
\text { todos os funcionários conheçam o negócio da empresa como um todo? }\end{array}$ \\
\hline & $\begin{array}{l}\text { 9. Freqüentemente se realizam reuniões e ou encontros especiais para ouvir } \\
\text { o que o empregado tem a dizer? }\end{array}$ \\
\hline & $\begin{array}{l}\text { 10. Do seu ponto de vista, as pessoas, ao desempenharem suas funções, } \\
\text { sabem para quê se destina o que estão fazendo? }\end{array}$ \\
\hline & $\begin{array}{l}\text { 11. O Sr. dá regularmente feedback aos seus subordinados sobre o } \\
\text { desempenho de suas tarefas? }\end{array}$ \\
\hline & $\begin{array}{l}\text { Planejamento da Comunicação: } \\
\text { 12. Existe um planejamento de comunicação organizacional? Este planejamento } \\
\text { está alinhado com o planejamento estratégico da empresa? }\end{array}$ \\
\hline \multirow{5}{*}{$\begin{array}{l}\text { GESTÃO DE PESSOAS/ } \\
\text { COMPROMETIMENTO }\end{array}$} & $\begin{array}{l}\text { 13. O Sr. acredita que existe um comprometimento dos colaboradores com a } \\
\text { empresa e eles se identificam com os objetivos organizacionais? Por quê? }\end{array}$ \\
\hline & $\begin{array}{l}\text { 14. Como o Sr. explica o engajamento dos colaboradores com os objetivos e } \\
\text { metas da empresa? }\end{array}$ \\
\hline & $\begin{array}{l}\text { 15. A seu ver, os colaboradores são considerados parceiros no trabalho e a } \\
\text { empresa investe neles para conseguir melhores resultados empresariais? } \\
\text { Como? }\end{array}$ \\
\hline & $\begin{array}{l}\text { 16. No seu entender a os colaboradores têm orgulho de pertencer esta } \\
\text { empresa? Porquê? o que os orgulha? }\end{array}$ \\
\hline & 17. Que papel desempenha a comunicação interna na gestão de pessoas? \\
\hline
\end{tabular}




\section{5 - População e amostra}

De acordo com Malhotra (2006, p. 420) população corresponde ao "agregado de todos os elementos, compartilhando algum conjunto de características comuns, que compõem o universo para o propósito do problema de pesquisa". Já a amostra consiste na seleção de um grupo de elementos com a intenção de descobrir alguma coisa sobre a população da qual foram extraídos, isto é, um conjunto da população.

Para Hair Jr. et al, (2005b, p. 237) a amostra é extraída, utilizando-se procedimentos probabilísticos ou não probabilísticos. Ao se extrair uma amostra probabilística, a seleção de elementos é baseada em algum procedimento aleatório que lhes dá uma chance concebida de serem selecionadas, minimizando a tendenciosidade de seleção. $\mathrm{Na}$ amostragem não probabilística, a seleção de elementos para a amostra não é necessariamente feita com o objetivo de ser estatisticamente representativa da população. Neste caso, a probabilidade de um elemento ser escolhido não é conhecida e não há métodos estatísticos para mensurar o erro de amostragem (HAIR JR. et al, 2005b). Na ilustração 6, a seguir, são apresentados os tipos mais comuns de métodos de amostragem.

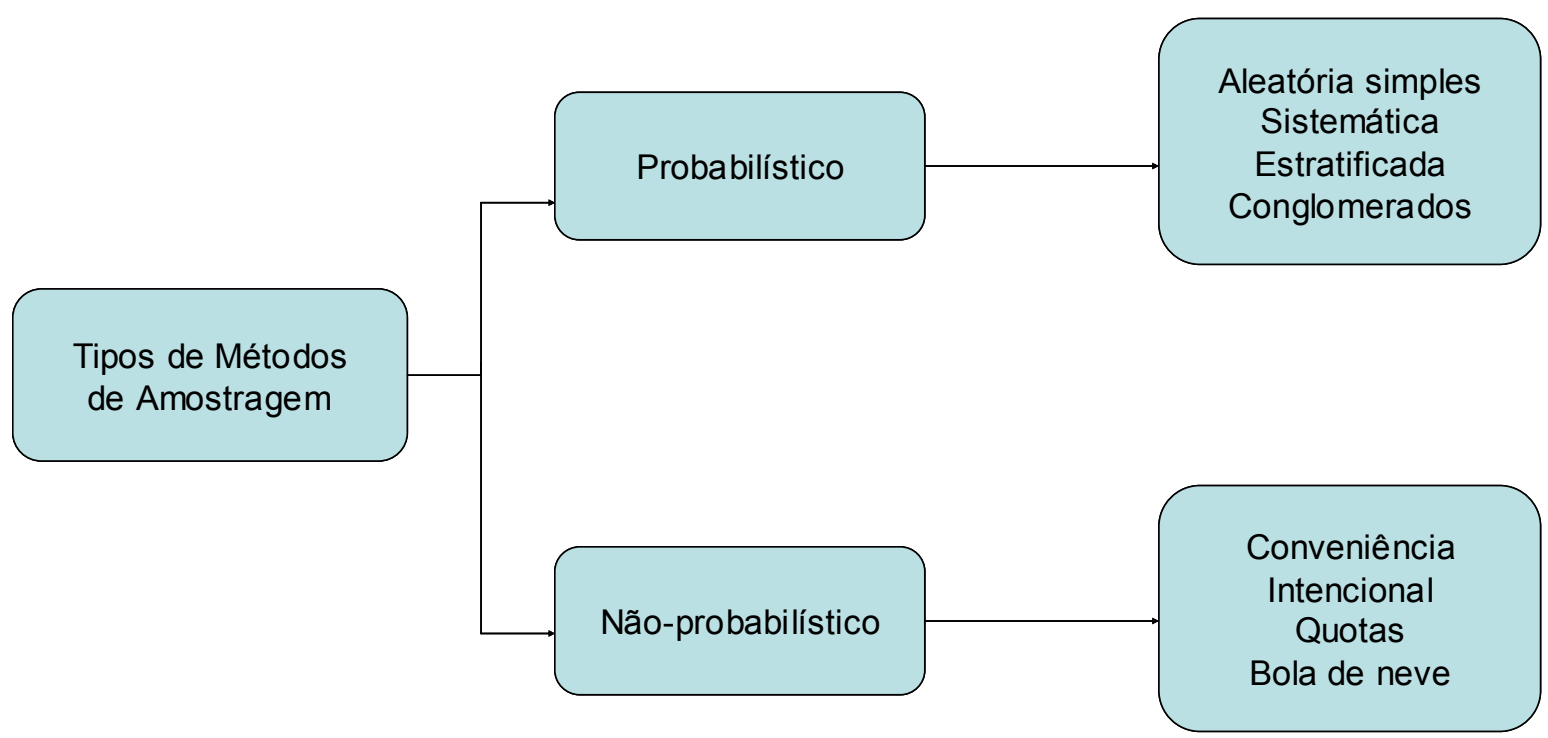

Ilustração 6 - Tipos de amostragem

FONTE: HAIR Jr. et al, (2005b, p. 241). 
$\mathrm{Na}$ amostragem probabilística, cada elemento da população tem uma chance fixa de ser incluído na amostra e possibilita ao pesquisador fazer inferências ou projeções sobre a populaçãoalvo, mediante o cálculo de intervalos de confiança. Já a amostragem não-probabilística não utiliza técnica de seleção aleatória e confia no julgamento pessoal do pesquisador, com a possibilidade de oferecer boas estimativas das características da população, mas não permitindo a avaliação objetiva da precisão dos resultados amostrais (MALHOTRA, 2006).

$\mathrm{Na}$ amostragem não probabilística o pesquisador usa métodos subjetivos, tais como a sua experiência pessoal, conveniência ou conhecimento especializado para selecionar os elementos da amostra. Mesmo não podendo generalizar as suas descobertas para a população-alvo com um grau mensurado de segurança, não significa que amostras não-probabilísticas não devem ser utilizadas. Em algumas situações, elas podem ser uma alternativa preferível. $O$ acesso e a participação dos respondentes constituem-se uma importante consideração para garantir que o tamanho da amostra seja confiável, eficiente e representativo (HAIR et al, 2005a).

Diante do que dizem os autores, a amostra utilizada, neste estudo, é denominada não probabilística e por conveniência, pois os elementos incluídos foram frutos do julgamento e de uma estratégia adequada aos objetivos do pesquisador e, sendo assim, a chance de cada elemento da população participar da amostra foi dada pelo julgamento do entrevistador que definiu quais elementos incluir na amostra.

Para compor a amostra decidiu-se escolher duas empresas do setor de telecomunicações de países diferentes. Foram realizadas pesquisas com os funcionários em cada uma das empresas escolhidas para o desenvolvimento do estudo.

A escolha das entidades participantes do estudo de casos foi feita por conveniência, levando em consideração o perfil das empresas, o ramo de atividade, ou seja, pertencer ao setor de atividade de telecomunicações, especificamente ao ramo de telefonia fixa.

Os funcionários da empresa de Cabo Verde foram selecionados a partir de uma lista de $e$ mails, fornecida pela empresa. A partir desta lista foram selecionados 200 funcionários, de diversos níveis hierárquicos, desde operacional/ de manutenção até o cargo de gerência, exceto as diretoras de RH e do Gabinete de Comunicação e Imagem e o Administrador executivo, pessoas 
com as quais foram realizadas as entrevistas. Desses 98 responderam completamente o questionário.

No caso da empresa do Brasil, foram feitas duas rodadas. O questionário foi enviado por e-mail, primeiramente, para uma lista de 600 funcionários. Depois de um mês, com comunicado semanal, solicitando a colaboração tivemos por volta de 80 respostas. Assim, foi enviado para uma outra lista de 300 pessoas que não participaram da primeira rodada, também com comunicado semanal, solicitando a colaboração e conseguimos mais 115 respostas válidas.Também, em relação a esta empresa, tivemos todo o cuidado para na lista estar pessoas de diversos níveis hierárquicos. Para as pessoas com as quais foram realizadas entrevistas, Diretor de Comunicação e Relações Corporativas e a Gerente de Recursos Humanos, não foram enviados os questionários. A amostra final obtida foi de 195 respondentes.

\section{6 - Protocolo do estudo}

O protocolo dos estudos de caso é segundo Martins (2006) um instrumento orientador e regulador da condução da estratégia de pesquisa. Para o autor o ponto central do protocolo (...) é um conjunto de questões que, de fato, refletem a investigação real. As questões são feitas ao próprio pesquisador e funcionam como um check-list para que o investigador fique atento e se lembre de todas as ações para condução do trabalho, particularmente, no levantamento das informações que precisam ser coletados e as razões de coletá-las.

Deste modo, o protocolo de estudos de casos não se constituiu somente um roteiro de entrevistas, mas sim um orientador de todas as informações que serão coletadas em todas as fontes de evidência.

Nos quadros 6 e 7 apresentam-se os protocolos dos estudos qualitativo e quantitativo, respectivamente. Ele relaciona as questões de pesquisa aos construtos que serão analisados. Cada construto já foi explorado no capítulo de referencial teórico na seção 2. A seguir, relaciona-se cada questão às fontes de evidência deste estudo e, por último, às questões no roteiro de pesquisa. 
Quadro $n^{0} 6$ - Protocolo de estudo qualitativo

\begin{tabular}{|c|c|c|c|}
\hline $\begin{array}{c}\text { Questões de } \\
\text { pesquisa }\end{array}$ & $\begin{array}{l}\text { Construtos a } \\
\text { serem } \\
\text { analisados }\end{array}$ & Questões no questionário de pesquisa & Fontes de evidência \\
\hline $\begin{array}{lr}\text { Quais } & \text { as } \\
\text { características } & \text { das } \\
\text { empresas } & \text { em } \\
\text { diferentes } & \\
\text { estruturas } & \text { do } \\
\text { mercado. } & \end{array}$ & $\begin{array}{l}\text { Qual o perfil } \\
\text { de cada } \\
\text { empresa. } \\
\text { Possíveis } \\
\text { fatores que as } \\
\text { diferenciam }\end{array}$ & $\begin{array}{l}\text { 1. Quantos empregados possui a empresa (sede, filiais/ } \\
\text { regiões e o grupo todo)? } \\
\text { 2. Qual a participação de mercado da empresa? } \\
\text { 3. Com que finalidade a empresa trabalha com os } \\
\text { conceitos de visão, missão, objetivos e metas? }\end{array}$ & $\begin{array}{l}\text { Entrevistas, } \\
\text { documentos internos, } \\
\text { notícias e pesquisas. }\end{array}$ \\
\hline $\begin{array}{l}\text { Qual } \\
\text { preocupação da } \\
\text { empresa com o } \\
\text { novo colaborador } \\
\text { em relação ao } \\
\text { conhecimento da } \\
\text { empresa como um } \\
\text { todo? }\end{array}$ & $\begin{array}{l}\text { Processo de } \\
\text { Socialização }\end{array}$ & $\begin{array}{l}\text { 4. Quando um novo integrante entra na empresa existe } \\
\text { um roteiro para apresentá-lo a todos? }\end{array}$ & $\begin{array}{l}\text { Entrevistas, } \\
\text { documentos internos, } \\
\text { notícias e pesquisas. }\end{array}$ \\
\hline $\begin{array}{lr}\text { Que } & \text { papel } \\
\text { desempenha } & \text { a } \\
\text { comunicação } & \\
\text { interna } & \text { na } \\
\text { organização? } & \end{array}$ & $\begin{array}{l}\text { Aspectos } \\
\text { sobre } \\
\text { Comunicação }\end{array}$ & $\begin{array}{l}\text { 5. A empresa adota uma política de comunicação } \\
\text { integrada? Porquê? Se sim, como se processa? } \\
\text { 6. Na sua opinião a comunicação interna é eficaz? } \\
\text { Porquê? } \\
\text { 7. Quais os canais de comunicação da organização que } \\
\text { traduzem diretrizes, inovações, normas e manifestações } \\
\text { nos mais variados assuntos? } \\
\text { 8. No seu entender, existe uma preocupação da empresa } \\
\text { em fazer com que todos os funcionários conheçam o } \\
\text { negócio da empresa como um todo? } \\
\text { 9. Freqüentemente se realizam reuniões e ou encontros } \\
\text { especiais para ouvir o que o empregado tem a dizer? } \\
\text { 10. Do seu ponto de vista, as pessoas, ao } \\
\text { desempenharem suas funções, sabem para quê se destina } \\
\text { o que estão fazendo? } \\
\text { 11. O Sr. dá regularmente feedback aos seus } \\
\text { subordinados sobre o desempenho de suas tarefas? }\end{array}$ & $\begin{array}{l}\text { Entrevistas, } \\
\text { documentos internos, } \\
\text { notícias e pesquisas. }\end{array}$ \\
\hline $\begin{array}{ll}\text { Como } & \text { a } \\
\text { comunicação } & \text { é } \\
\text { tratada dentro da } \\
\text { organização? }\end{array}$ & $\begin{array}{l}\text { Planejamento } \\
\text { da } \\
\text { Comunicação: }\end{array}$ & $\begin{array}{l}\text { 12. Existe um planejamento de comunicação } \\
\text { organizacional? Este planejamento está alinhado com o } \\
\text { planejamento estratégico da empresa? }\end{array}$ & $\begin{array}{l}\text { Entrevistas, } \\
\text { documentos internos, } \\
\text { notícias e pesquisas. }\end{array}$ \\
\hline $\begin{array}{ll}\text { Como é a política } \\
\text { de Gestão de } \\
\text { Pessoas } & \text { na } \\
\text { organização? } & \end{array}$ & $\begin{array}{l}\text { Gestão de } \\
\text { pessoas/ } \\
\text { comprometim } \\
\text { ento }\end{array}$ & $\begin{array}{l}\text { 13. O Sr. acredita que existe um comprometimento dos } \\
\text { colaboradores com a empresa e eles se identificam com } \\
\text { os objetivos organizacionais? Porquê? } \\
\text { 14. Como o Sr. explica o engajamento dos } \\
\text { colaboradores com os objetivos e metas da empresa? } \\
\text { 15. A seu ver, os colaboradores são considerados } \\
\text { parceiros no trabalho e a empresa investe neles para } \\
\text { conseguir melhores resultados empresariais? Como? } \\
\text { 16. No seu entender a os colaboradores têm orgulho de } \\
\text { pertencer esta empresa? Porquê? O que os orgulha? } \\
\text { 17. Que papel desempenha a comunicação interna na } \\
\text { gestão de pessoas? }\end{array}$ & $\begin{array}{l}\text { Entrevistas, } \\
\text { documentos internos, } \\
\text { notícias e pesquisas. }\end{array}$ \\
\hline
\end{tabular}


Quadro no 7 - Protocolo de estudo quantitativo

\begin{tabular}{|c|c|c|c|}
\hline $\begin{array}{l}\text { Questões de } \\
\text { pesquisa }\end{array}$ & Construtos a serem analisados & $\begin{array}{c}\text { Questões no roteiro de } \\
\text { entrevista }\end{array}$ & Fontes de evidência \\
\hline \multirow{5}{*}{$\begin{array}{l}\text { Como se } \\
\text { processa } \\
\text { comunicação } \\
\text { interna dentro da } \\
\text { organização? }\end{array}$} & \multicolumn{2}{|l|}{ Comunicação interna } & \multirow{5}{*}{$\begin{array}{l}\text { Entrevistas, documentos } \\
\text { internos, notícias e } \\
\text { pesquisas. }\end{array}$} \\
\hline & $\begin{array}{l}\text { Processamento da comunicação } \\
\text { interna }\end{array}$ & $\begin{array}{l}9,15,17,18,22,24,34, \\
44,50,52\end{array}$ & \\
\hline & Redes e fluxos & $4,7,26,28,30,48$ & \\
\hline & Canais e meios & $1,3,5,11$ & \\
\hline & Planejamento da comunicação & $2,32,36,38,40,42$ & \\
\hline \multirow{4}{*}{$\begin{array}{l}\text { Os funcionários } \\
\text { estão } \\
\text { comprometidos } \\
\text { com a } \\
\text { organização? }\end{array}$} & \multicolumn{2}{|l|}{ Comprometimento } & \multirow{4}{*}{$\begin{array}{l}\text { Entrevistas, documentos } \\
\text { internos, notícias e } \\
\text { pesquisas. }\end{array}$} \\
\hline & Afetivo & $\begin{array}{l}6,8,10,12,14,16,19 \\
21,39,46\end{array}$ & \\
\hline & Normativo & $\begin{array}{l}35,37,41,43,45,47 \\
49,51,53\end{array}$ & \\
\hline & Instrumental & $23,25,27,29,31,33$ & \\
\hline
\end{tabular}

\section{7 - Procedimento de coleta de dados e forma de abordagem}

Uma vez definida a natureza ou tipo de pesquisa, é necessária a definição do melhor método de coleta de dados a ser utilizado. Entre os métodos pertinentes à pesquisa quantitativa e qualitativa, pretende-se escolher aquele que melhor se ajuste à natureza do problema investigado e aos objetivos da pesquisa.

Segundo Gil (2002) "construir um questionário consiste basicamente em traduzir os objetivos da pesquisa em questões específicas. As respostas a essas questões é que irão proporcionar os dados requeridos para testar as hipóteses ou esclarecer o problema de pesquisa" (GIL, 2002, p. 129).

Selltiz et al, (2005) ressaltam que o uso de questionários é um processo menos dispendioso do que entrevistas, permitindo sua aplicação a um grande número de pessoas ao mesmo tempo. Além disso, seu uso permite a uniformização das informações - o que possibilita comparar as respostas de um grande número de indivíduos para se ter uma visão mais abrangente do problema de pesquisa. Para os autores a natureza impessoal do questionário - frases padronizadas, ordem padronizadas de perguntas, instruções padronizadas para o registro de respostas - assegura certa uniformidade de uma situação de mensuração para outra. Também 
realçam que em alguns tipos de entrevista, o entrevistador não tem um conjunto padronizado de perguntas que deva fazer, o que torna é menos fácil comparar entrevistas que questionários.

A formulação das questões foi feita considerando-se a clareza para os respondentes e a ordem de resposta. Segundo Goode e Hatt (1969) as perguntas devem seguir uma ordem que vise a obtenção da participação do informante. Para tanto, as mais atraentes e menos complexas, assim como as mais simples e as mais neutras (em que não há exigência de informações pessoais) devem vir no início, seguindo uma "progressão lógica" que facilite o entendimento e as respostas.

Yin (2005) enriquece o entendimento do método, lembrando da importância das múltiplas fontes de evidência possíveis, quando define estudo de caso como sendo "uma investigação empírica que investiga um fenômeno contemporâneo dentro de seu contexto de vida real, especialmente quando os limites entre o fenômeno e o contexto não estão claramente definidos" (YIN, 2005, p.32).

Os instrumentos de coleta de dados foram elaborados considerando-se os objetivos deste estudo, abordando os construtos da pesquisa e procurando parâmetros que as explicam. Para a pesquisa quantitativa foi utilizado um questionário estruturado, com perguntas fechadas (apêndice A), previamente testado, dentro de uma relação de temas preestabelecidos. O questionário foi disponibilizado de forma eletrônica, posto que as empresas informaram que todos tinham acesso ao computador e Internet. $\mathrm{O}$ formato do questionário resultou em três partes: a primeira parte com 4 questões sobre comunicação, sendo duas com várias opções de respostas e 2 com várias alternativas, mas com uma única opção de resposta. A segunda parte, com 49 questões que tratavam de comprometimento organizacional (afetivo, instrumental e normativo, adaptado de Meyer e Allen, 1997) e comunicação interna (adaptado de Kunsch, 2003 e Marchiori, 2006), com uma escala tipo Likert de 4 pontos, variando de discordo totalmente a concordo totalmente. $\mathrm{O}$ instrumento apresenta indicadores das seguintes variáveis: Comunicação interna (promoção de comunicação interna eficaz; meios e instrumentos para promoção da comunicação interna); Comprometimento organizacional: afetivo (identificação com os valores da empresa, conhecimento do negócio como um todo; engajamento dos colaboradores com a visão e missão da empresa, envolvimento e identificação com a organização, orgulho de pertencer; instrumental (permanecem porque precisam, está preparado para o mercado de trabalho, os benefícios da empresa, os custos associados a deixar a organização) e normativo 
(comprometimento como uma obrigação em permanecer na organização). Na terceira e última parte do questionário, tinha 9 questões referentes aos dados demográficos e funcionais. Foi apresentada uma carta explicativa com o objetivo da pesquisa, garantindo o sigilo dos dados individuais.

Para a etapa da coleta de dados houve o apoio das empresas pesquisadas. A empresa cabo-verdiana disponibilizou os e-mails dos funcionários e a empresa brasileira enviou os questionários aos funcionários, indicando o link para o envio das respostas. Ambas as empresas fizeram um trabalho de sensibilização, enviando e-mails aos funcionários, informando-lhes da pesquisa e solicitando a colaboração com a mesma.

A pesquisa qualitativa foi realizada com base nos objetivos da pesquisa assim como aspectos levantados durante a pesquisa quantitativa. A realização das entrevistas com as pessoas que ocupam cargo de diretoria e gerência foi auxiliada por um roteiro semi-estruturado e organizado em blocos de assuntos (ver apêndice B).

\subsection{1 - Pré-teste do instrumento}

Segundo Kinnear e Taylor (1996, p. 501) o pré-teste é necessário para avaliar:

* Se os termos empregados no questionário são facilmente entendidos pelos entrevistados;

* Se as perguntas foram entendidas como deveriam ser;

- Se as opções de resposta cobrem todas as possíveis alternativas;

* Se há objeção em responder algumas perguntas.

Tendo em conta as considerações desses autores foi realizado o pré-teste. Ciente de que a entrevista pessoal pode apresentar a melhor maneira de realizar um pré-teste do instrumento de coleta de dados, mesmo que a pesquisa real venha a ser realizada por outro meio (MALHOTRA, 2006, p. 308), o pré-teste com os funcionários da empresa brasileira foi realizado pessoalmente 
(contato direto entre entrevistador e entrevistado). No entanto, com os funcionários da empresa de Cabo Verde foi feita via e-mail, devido à distância geográfica.

De acordo com Hair et al, (2005a) com relação ao tamanho ideal da amostra de um préteste, o menor número pode ser de quatro ou cinco e o máximo de 30 indivíduos. Levando em consideração as considerações dos autores o pré-teste foi feito com 10 respondentes de cada empresa pesquisada. Procurou-se incluir no pré-teste pessoas de todos os níveis (operacional, técnico e administrativo), pois a pesquisa visou todos os níveis/ cargos existentes na empresa, exceto a alta administração para a pesquisa quantitativa.

O objetivo do pré-teste foi de identificar e eliminar possíveis erros e questões ambíguas; verificar se as perguntas elaboradas remetiam às respostas desejadas e se era possível pensar em outras perguntas; se elas atendiam aos objetivos deste trabalho e se as questões elaboradas se apresentavam claras.

A análise das respostas trouxe subsídios para alguns ajustes no instrumento, pois algumas sugestões mostraram-se bastante pertinentes. Elaborada a segunda versão (apêndice A), esta passou novamente pela revisão dos voluntários que participaram da primeira. Percebeu-se que as

questões estavam alinhadas ao estudo e que traziam as informações que se desejava obter. Elas também estavam de fácil compreensão e facilitavam a coleta das informações.

A coleta dos dados na empresa A, Cabo Verde, foi realizada entre janeiro e fevereiro de 2009 e na empresa B, Brasil, foi feita entre abril e maio do mesmo ano.

A seguir são descritos os procedimentos adotados para análises dos dados coletados durante a pesquisa.

\section{8 - Desenho da pesquisa}

O desenho da pesquisa constitui-se de um sistema de conceitos representativos do fenômeno em análise e de suas relações. Deste modo, apresenta-se, a seguir, as variáveis deste estudo, esquematizada na ilustração 7. 
4.8.1 Variáveis independentes: foram designadas de variáveis independentes as sociodemográficas e comunicação interna.

As variáveis sociodemográficas analisadas foram: escolaridade, categorizada em "ensino básico integrado/ primário incompleto", “ensino básico integrado/ primário completo", “ensino secundário incompleto", "ensino secundário completo", "ensino médio incompleto", “ensino médio completo", "ensino superior incompleto", "ensino superior completo"; sexo, "masculino" e "feminino"; idade, categorizado em "18|---|25 anos", “26|---|35”, “36|---|45”, “46-|---|60” e “ > 60 anos"; anos de serviço na empresa, “<2 anos", "2|---|5”, “6|---|8”, “9|---|11” e "> 12 anos"; estado civil, "solteiro", "casado", "viúvo" e "outro"; ter filhos, "sim" e "não"; e a variável comunicação, coletada por meio de um instrumento composto por 24 questões cujas opções são pontuadas (1 a 4) de acordo com a presença, "quando respondida 1 ou 2" e a ausência de uma boa comunicação "quando respondida 3 ou 4".

\subsubsection{Variável dependente:}

A variável dependente do estudo foi comprometimento composto por 25 questões, cujas opções são pontuadas (1 a 4) de acordo com a presença de comprometimento, "quando respondida 1 ou 2" e a ausência "quando respondida 3 ou 4".

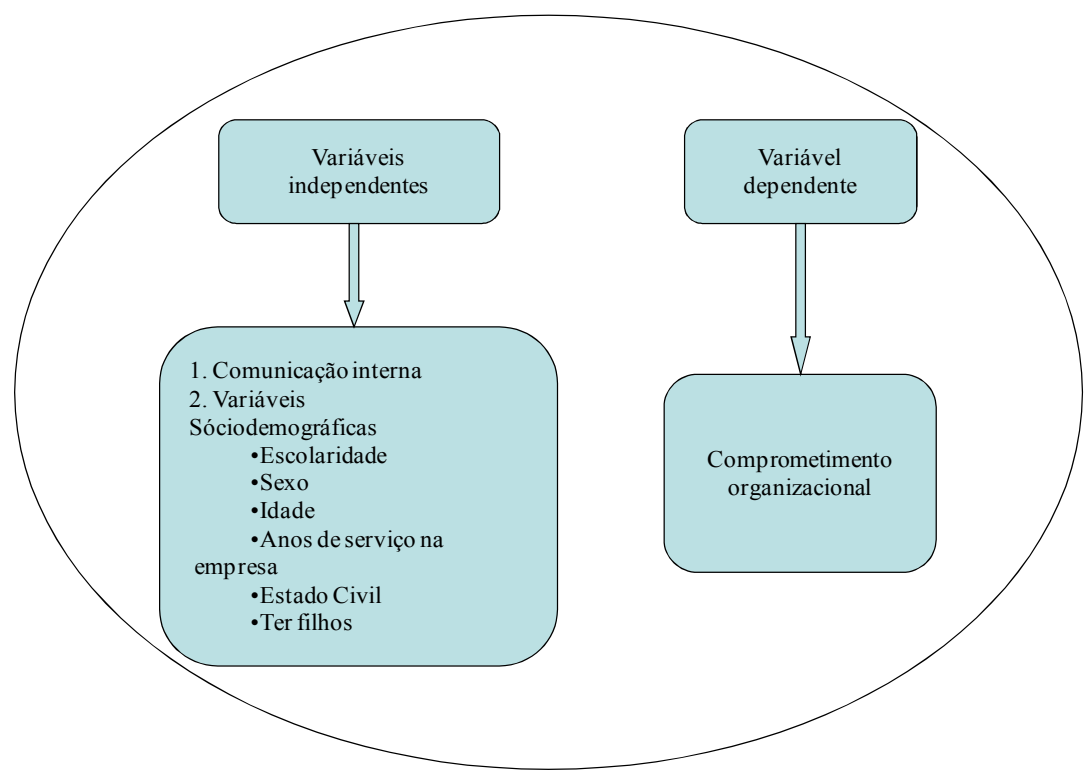

Ilustração 7 - Desenho da I pesquisa 


\title{
4.9 - Procedimento para análise dos dados
}

Para o alcance dos objetivos deste estudo foi elaborado um plano de análise dos resultados.

A análise dos dados consiste em examinar, categorizar, tabular ou novamente combinar a evidência, para ligá-los às proposições iniciais do estudo (YIN, 2005).

De acordo com Gil (2002, p. 141):

\begin{abstract}
Um dos maiores problemas na interpretação dos dados no estudo de caso deve-se à falsa sensação de certeza que o próprio pesquisador pode ter sobre suas conclusões [...] Convém, portanto, que o pesquisador desenvolva logo no início da pesquisa um quadro de referência teórico com vista a evitar especulações no momento de análise.
\end{abstract}

A análise dos dados foi realizada por intermédio do pacote estatístico STATA, versão 10.0. Foram realizadas algumas análises estatísticas descritivas, que segundo Stevenson (1981) têm por objetivo tornar os dados mais fáceis de estudar, relatar e discutir.

Segundo Stevenson (1981), estatística descritiva compreende a organização, o resumo e, em geral, a simplificação de informações que podem ser muito complexas. Ela compreende análises que descrevem os dados, como por exemplo, médias, histogramas e distribuições de freqüência. Neste estudo as variáveis foram descritas por meio de porcentagens.

Para análises de dependência entre as variáveis, utilizou-se o teste qui-quadrado de Pearson ou teste exato de Fisher (Dupont, 2002), este último quando o Pearson não fosse adequado, no modelo univariado.

Os fatores associados que apresentaram valores de $p<20 \%$ na análise univariada foram incluídos nos modelos múltiplos de regressão logística e de Poisson ajustado pela estimativa robusta de variância (DUPONT, op. cit.). Nesta análise, os dados foram analisados hierarquicamente: as variáveis sociodemográficas no nível proximal e a da comunicação no distal. O nível de significância adotado foi de $5 \%$ ou $10 \%$.

$\mathrm{Na}$ estimativa dos fatores associados das variáveis sociodemograficas e/ou da comunicação, foram utilizados modelos múltiplos, logístico e Poisson robusto (Backward 
stepwise Wald) (Dupont, op. cit.), com o intuito de verificar a melhor opção por se tratar de um estudo transversal.

\subsection{0 - Síntese dos métodos de pesquisa}

No quadro 8, a seguir, apresenta-se a síntese dos métodos e instrumentos de pesquisa.

Quadro nº 8 - Síntese dos métodos e instrumentos de pesquisa

\begin{tabular}{|c|c|}
\hline Aspectos & Etapas \\
\hline $\begin{array}{l}\text { Tipos de } \\
\text { pesquisa }\end{array}$ & Exploratória, descritiva e transversal. \\
\hline $\begin{array}{l}\text { Método de } \\
\text { pesquisa }\end{array}$ & $\begin{array}{l}\text { Estudo de casos com abordagens quantitativa, envolvendo os funcionários de uma forma geral } \\
\text { e qualitativa com a diretoria e gerência. }\end{array}$ \\
\hline População & Duas empresas do setor de Telecomunicações \\
\hline Amostra & $\begin{array}{l}\text { Empregados de duas empresas de telefonia fixa, uma em Cabo Verde e outra no Brasil. } \\
\text { Empresa A: } 98 \text { respondentes na pesquisa quanti. Diretoras de RH e do Gabinete de } \\
\text { Comunicação e Imagem e o Administrador Executivo na pesquisa quali. } \\
\text { Empresa B: } 195 \text { respondentes na pesquisa quanti. Diretor de Comunicação e Relações } \\
\text { Corporativas e a Gerente de RH }\end{array}$ \\
\hline $\begin{array}{l}\text { Métodos de } \\
\text { seleção da } \\
\text { amostra }\end{array}$ & Não probabilístico, por conveniência. \\
\hline $\begin{array}{l}\text { Protocolo de } \\
\text { estudo }\end{array}$ & $\begin{array}{l}\text { Protocolos de estudo qualitativo e quantitativo com questões de pesquisa referentes aos } \\
\text { constructos analisados. }\end{array}$ \\
\hline $\begin{array}{l}\text { Instrumento de } \\
\text { pesquisa }\end{array}$ & $\begin{array}{l}\text { Questionário estruturado auto-administrativo, pesquisa quantitativa - Apêndice A } \\
\text { Roteiro semi-estruturado, para pesquisa qualitativa - Apêndice B }\end{array}$ \\
\hline $\begin{array}{l}\text { Procedimento } \\
\text { para coleta dos } \\
\text { dados }\end{array}$ & $\begin{array}{l}\text { Os questionários foram enviados por Internet, via e-mail. As entrevistas foram realizadas } \\
\text { pessoalmente com a gerência, diretoria. } \\
\text { Empresa A: realizada entre janeiro e fevereiro de } 2009 \text {. } \\
\text { Empresa B: entre abril e maio do mesmo ano. }\end{array}$ \\
\hline Pré-teste & $\begin{array}{l}\text { Do questionário de pesquisa, com } 10 \text { respondentes de cada empresa pesquisada. } \\
\text { Empresa A: via e-mail } \\
\text { Empresa B: presencial }\end{array}$ \\
\hline $\begin{array}{l}\text { Técnicas de } \\
\text { análise dos dados }\end{array}$ & $\begin{array}{l}\text { Análise descritiva dos construtos estudados. } \\
\text { Teste Qui-quadrado de Pearson ou Exato de Fisher - fatores associados que apresentaram } \\
\text { valores de p<20\% foram incluídos no modelo múltiplo: } \\
\text { Regressão logística e de Poisson robusto (Backward stepwise Wald). } \\
\text { Adotou-se o nível de significância de } 5 \text { ou } 10 \% \text {. }\end{array}$ \\
\hline
\end{tabular}


A seguir, apresentaremos os resultados da pesquisa, descritiva e de associação. No entanto, em função da peculiaridade da empresa A, descreveremos de forma sucinta o histórico, $\mathrm{o}$ perfil e o contexto em que ela atua, por entendermos que essas características podem ter relações com os resultados. 
5. ANÁLISE DOS RESULTADOS 
Nesta sessão serão apresentados os resultados obtidos com a realização da pesquisa de campo.

\subsection{Histórico da empresa A - Cabo Verde}

Antes de apresentar os resultados da pesquisa, considera-se importante descrever, de forma sucinta, as características da empresa A, pela sua especificidade. Existe em Cabo Verde um único operador de serviços de telecomunicações, com exclusividade dos serviços básicos da telefonia fixa, a empresa A. Em 1995, iniciou-se a privatização da empresa A. Atualmente, $58.7 \%$ da empresa pertence a interesses privados e o capital encontra-se dividido pela Portugal Telecom Ventures SGPS (40\%), Instituto Nacional de Previdência Social (37.9\%), Sonangol (5\%), Trabalhadores da empresa A (5\%) e o Estado de Cabo Verde (3.4\%). O acesso é feito pela atribuição de licença pelo membro do Governo responsável pela área das telecomunicações, com a condição de verificação dos requisitos constantes no diploma e sempre precedido de concurso público. O contrato de concessão concede à empresa A um regime de exclusividade, por um período de 25 anos, com possibilidades de renovações sucessivas por períodos mínimos de 15 anos. Preparando o lançamento do serviço de Televisão por Assinatura e o aparecimento de novos operadores de Internet e Telefonia Móvel em 2007 a empresa A deu origem a três empresas: a gestora da rede e do negócio de telefonia fixa, a que explora a rede móvel, e a que dedica às ligações via Internet e a Televisão por Assinatura. A empresa estudada tem sede na cidade da Praia, ilha de Santiago, com uma Coordenação Local no Interior da Ilha de Santiago para cobrir o interior da ilha; duas Coordenações Locais nas ilhas de Fogo e Brava e Sal e Boavista e uma Coordenação Regional Norte que compreende as outras ilhas (RELATÓRIO E CONTAS 2007 DA EMPRESA A).

A empresa A tem faturamento anual de 4.450 milhões de escudos cabo-verdianos; um total de 408 colaboradores, sendo 16,4\%, com formação superior; $11 \%$ com formação médio; $57,6 \%$ técnicos operacionais e 15\% profissionais de apoio (DADOS DA PESQUISA). 


\subsection{Análise descritiva da empresa A}

Dentre os 98 respondentes - que representa cerca de 49,0\% do total dos questionários enviados (200) e cerca de $25,0 \%$ da população (408) - encontrou-se 46,9\% de homens e 53,1\% de mulheres (proporção parecida entre os sexos); 73,5\% dos respondentes têm entre 26 e 45 anos de idade; mais do que metade $(56,1 \%)$ tem mais de 6 anos de serviço; 53,1\% dos respondentes tem nível superior completo, sendo que o resto se divide em 15,3\% com nível médio e 31,6\% com segundo grau completo; $56,1 \%$ solteiro, $37,8 \%$ casado; $74,5 \%$ tem filhos.

\subsubsection{Aspectos sobre a comunicação interna:}

As variáveis que compõem a categoria comunicação interna têm como objetivo descrever como funciona o processo comunicativo dentro da organização. A tabela 1, a seguir, ilustra alguns resultados. Percebe-se que os participantes concordaram que o processo comunicativo dentro da empresa permite a comunicação em todas as direções, mediante vários meios, redes e fluxos, com taxas de concordância superiores a 90\% em todas as questões. Um outro aspecto bastante positivo da comunicação planejada é a elevada porcentagem $(80 \%)$ das pessoas que participam de decisões que afetam os seus trabalhos. Em relação a algumas questões que foram formuladas na forma negativa, como por exemplo, - eu não recebo informações de outros setores/ departamentos da empresa - percebe-se a concentração das respostas em discordo, com 66\%. A existência de vários canais e meios de comunicação utilizados é percebido pela maioria, 83\%. No entanto, quando perguntado se o processo de comunicação interna é eficiente, eficaz e satisfatório só $64 \%$ concordaram. Para que a área de comunicação ocupe uma posição estratégica dentro da organização deve existir uma área que planeje a comunicação e esta deve ser planejada pensada e administrada estrategicamente. Existe a percepção da maioria, 80\%, de que existe essa área e que ela ocupa um espaço estratégico. Quanto a algumas questões que foram formuladas na forma negativa, como por exemplo - a área de comunicação só funciona para resolver problemas em momentos de crise - observou-se a concentração nas discordâncias, (85\%). 
Tabela no 1 - Algumas questões da variável comunicação. Empresa A, Cabo Verde, 2008

\begin{tabular}{|c|c|c|c|}
\hline Perguntas & Alternativa & $\mathbf{N}$ & $\%$ \\
\hline \multirow{4}{*}{$\begin{array}{l}\text { P5- A empresa permite a comunicação entre ela e os } \\
\text { funcionários }\end{array}$} & Concordo totalmente & 23 & 23,5 \\
\hline & Concordo & 67 & 68,4 \\
\hline & Discordo & 7 & 7,1 \\
\hline & Discordo totalmente & 1 & 1,0 \\
\hline \multirow{4}{*}{$\begin{array}{l}\text { P7- Nesta empresa a comunicação prioritária é a de baixo } \\
\text { para cima. }\end{array}$} & Concordo totalmente & 4 & 4,1 \\
\hline & Concordo & 14 & 14,3 \\
\hline & Discordo & 63 & 64,2 \\
\hline & Discordo totalmente & 17 & 17,4 \\
\hline \multirow{4}{*}{$\begin{array}{l}\text { P9- Nesta empresa a comunicação é vista como importante } \\
\text { para o bom funcionamento do negócio. }\end{array}$} & Concordo totalmente & 32 & 32,7 \\
\hline & Concordo & 56 & 57,1 \\
\hline & Discordo & 10 & 10,2 \\
\hline & Discordo totalmente & 0 & 0,0 \\
\hline \multirow{4}{*}{$\begin{array}{l}\text { P11- Existem canais que permitem comunicação com os } \\
\text { funcionários de todos os níveis. }\end{array}$} & Concordo totalmente & 32 & 32,7 \\
\hline & Concordo & 49 & 50,0 \\
\hline & Discordo & 16 & 16,3 \\
\hline & Discordo totalmente & 1 & 1,0 \\
\hline \multirow{4}{*}{$\begin{array}{l}\text { P15- Eu não recebo informações de outros setores/ } \\
\text { departamentos da empresa }\end{array}$} & Concordo totalmente & 4 & 4,1 \\
\hline & Concordo & 29 & 29,6 \\
\hline & Discordo & 56 & 57,1 \\
\hline & Discordo totalmente & 9 & 9,2 \\
\hline \multirow{4}{*}{$\begin{array}{l}\text { P22- Nesta empresa existem mecanismos que me permitem } \\
\text { falar com meus superiores diretos, indiretos e colegas. }\end{array}$} & Concordo totalmente & 30 & 30,6 \\
\hline & Concordo & 61 & 62,3 \\
\hline & Discordo & 7 & 7,1 \\
\hline & Discordo totalmente & 0 & 0,0 \\
\hline \multirow{4}{*}{$\begin{array}{l}\text { P24- Tenho oportunidade de participar de decisões que } \\
\text { afetam o meu trabalho. }\end{array}$} & Concordo totalmente & 20 & 20,4 \\
\hline & Concordo & 58 & 59,2 \\
\hline & Discordo & 18 & 18,3 \\
\hline & Discordo totalmente & 2 & 2,1 \\
\hline \multirow{4}{*}{$\begin{array}{l}\text { P28- Sou informado (a) sobre o que se passa dentro da } \\
\text { empresa. }\end{array}$} & Concordo totalmente & 10 & 10,2 \\
\hline & Concordo & 53 & 54,1 \\
\hline & Discordo & 35 & 35,7 \\
\hline & Discordo totalmente & 0 & 0,0 \\
\hline \multirow{4}{*}{$\begin{array}{l}\text { P32- A área de comunicação, nesta empresa, só funciona } \\
\text { para resolver problemas em momentos de crise. }\end{array}$} & Concordo totalmente & 1 & 1,0 \\
\hline & Concordo & 14 & 14,3 \\
\hline & Discordo & 64 & 65,3 \\
\hline & Discordo totalmente & 19 & 19,4 \\
\hline \multirow{4}{*}{$\begin{array}{l}\text { P36- As estratégias de comunicação, nesta empresa, são } \\
\text { traçadas a partir da visão, missão, valores da empresa, } \\
\text { visando o alcance de resultados. }\end{array}$} & Concordo totalmente & 25 & 25,5 \\
\hline & Concordo & 67 & 68,4 \\
\hline & Discordo & 6 & 6,1 \\
\hline & Discordo totalmente & 0 & 0,0 \\
\hline \multirow{4}{*}{$\begin{array}{l}\text { P38 - A área de comunicação, nesta empresa, é planejada, } \\
\text { pensada e administrada estrategicamente. }\end{array}$} & Concordo totalmente & 13 & 13,3 \\
\hline & Concordo & 63 & 64,2 \\
\hline & Discordo & 19 & 19,4 \\
\hline & Discordo totalmente & 3 & 3,1 \\
\hline \multirow{4}{*}{$\begin{array}{l}\text { P40- O processo de comunicação nesta empresa promove a } \\
\text { integração entre os diferentes setores/ departamentos }\end{array}$} & Concordo totalmente & 9 & 9,2 \\
\hline & Concordo & 64 & 65,1 \\
\hline & Discordo & 23 & 23,4 \\
\hline & Discordo totalmente & 2 & 2,0 \\
\hline
\end{tabular}




\begin{tabular}{llcc}
\multicolumn{1}{c}{ Perguntas } & \multicolumn{2}{c}{ Alternativa } & (continuação) \\
\hline P42- A comunicação, nesta empresa, ocupa um espaço & \multicolumn{1}{c}{ Concordo totalmente } & 23 & 23,5 \\
estratégico na estrutura organizacional. & Concordo & 55 & 56,1 \\
& Discordo & 19 & 19,4 \\
& Discordo totalmente & 1 & 1,0 \\
\hline P48- Eu recebo feedback dos meus superiores sobre & Concordo totalmente & 31 & 31,6 \\
desempenho das minhas funções. & Concordo & 56 & 57,2 \\
& Discordo & 10 & 10,2 \\
& Discordo totalmente & 1 & 1,0 \\
\hline P50- O processo de comunicação interna na empresa é & Concordo totalmente & 9 & 9,2 \\
eficiente, eficaz e satisfatório. & Concordo & 54 & 55,1 \\
& Discordo & 31 & 31,6 \\
& Discordo totalmente & 4 & 4,1 \\
\hline
\end{tabular}

Observou-se que o processo comunicativo na organização funciona, utilizando vários meios, redes formais e informais. Os fluxos de informação permitem a comunicação com chefias, pares e subordinados. No entanto, embora os respondentes percebessem que existe uma área de comunicação dentro da empresa, que ela é estratégica assim como a importância da mesma para a organização, uma boa parte dos respondentes, 34\%, afirma não receber informações de outros setores ou departamentos da empresa. Um número significativo dos respondentes, $85 \%$, discorda que a área de comunicação funciona só para resolver problemas em momentos de crise, porém, uma porcentagem significativa, 36\%, discorda em relação à sua eficiência e eficácia e que ela seja satisfatória.

Nas entrevistas com a Diretora do Gabinete de Comunicação e Imagem, Diretora de Recursos Humanos e com o Administrador Executivo fica evidente a importância da comunicação interna dentro da empresa o que vem ao encontro da percepção dos colaboradores pesquisados. O Administrador Executivo declarou que a comunicação interna não é eficaz, pois segundo ele para alcançar a eficácia é preciso que se funcione de forma plena, ou seja, com perfeição. Essa opinião pode explicar a porcentagem de colaboradores, 36\%, que na pesquisa quantitativa discordaram no que se refere à eficiência, eficácia da comunicação interna. Segue excertos da entrevista com o administrador executivo em relação à eficácia da comunicação interna:

A comunicação interna não é eficaz, pois ser eficaz quer dizer que teríamos chegado no topo. ... Até no inquérito externo uma das nossas lacunas é a comunicação, mas principalmente a comunicação horizontal. Temos vários departamentos e é evidente que todos nós estamos a trabalhar para um mesmo fim, para os objetivos da empresa e nem 
toda a gente está ainda, infelizmente, imbuída desse desiderato. Eu vejo ainda que há uma mentalidade de ilha, há uma tendência das pessoas considerarem o proprietário do seu departamento, esse é o meu departamento, a Rosa não pode vir aqui me criticar. Esse é um dos aspectos mais negativos que temos ainda, infelizmente, porque entrava introduzir eficiência nos processos, entrava o desenvolvimento dos serviços, introduz déficits de eficiência e eficácia e conseqüentemente tem muita influência nos resultados da empresa. Um dos grandes desafios que nós temos, um dos aspectos que foi diagnosticado no processo do nosso programa de qualidade desde 2002 e ainda prevalece. Um dos focos do projeto qualidade foi quebrar as barreiras da comunicação horizontal, das sessões, dos departamentos e das direções. Por isso desenvolvemos ações do tipo que chamamos de sessões plenárias onde pessoas de diversos níveis hierárquicos e transversais juntos para discutirem problemas da atualidade da empresa. Desde engenheiros, diretores até ajudantes juntos numa sala. Por isso organizamos chamados células de qualidade em grupos de qualidades de diversos níveis também e diversos setores justamente para quebrar a idéia de que eu sou do comercial aquele é de $\mathrm{RH}$, aquele é de logística ... levar as pessoas a interiorizar de que a equipa é empresa de telecomunicações, só que circunstancialmente está na financeira ou na logística ou na RH, mas trabalhamos para o mesmo fim (ADMINISTRADOR EXECUTIVO DA EMPRESA A).

Em relação ao compartilhamento de informações entre setores/ departamentos da empresa, o Administrador Executivo entende que deixa a desejar, o que também pode elucidar os $34 \%$ dos respondentes da pesquisa quantitativa que declararam não receber informações de outros setores ou departamentos.

Trechos da entrevista, a seguir, relatam essa percepção.

(...) A empresa adota um sistema de comunicação integrada porque a comunicação é crucial para a integração interna, mobilização, identificação com a cultura da empresa. (...) A comunicação interna é fundamental para que os colaboradores saibam, conheçam os objetivos da empresa, quais as disponibilidades da empresa, os planos da empresa. ... A comunicação tanto vertical como horizontal são questões incontornáveis e na gestão moderna a comunicação é fundamental. Nós somos uma empresa que depende muito dos RH, nos somos uma empresa de prestação de serviços, temos tecnologia, mas para potenciar essa tecnologia temos que ter as pessoas e estas tem que estar sensibilizadas, mobilizadas, fazer parte da equipe, e para isso tem que estar informada e para estar informada tem que se comunicar. (...) Tal como a tecnologia a comunicação é fundamental. Daí termos criado há cerca de oito anos o Gabinete de Comunicação e Imagem que ocupa dentre outras coisas da comunicação interna, manter os colaboradores minimante informados para mantermos os colaboradores engajados e mobilizados no sentido de alcançarmos com sucesso os objetivos (ADMINISTRADOR EXECUTIVO DA EMPRESA A).

No que se refere à existência de uma política de comunicação interna, a Diretora do Gabinete concorda que existe, justificando tal existência ao declarar que "a idéia é trabalhar no 
sentido de integrar e garantir que a comunicação chegue a todos os colaboradores" (DIRETORA DO GABINETE DE COMUNICACÃO E IMAGEM DA EMPRESA A).

\subsubsection{Aspectos sobre comprometimento organizacional:}

O constructo comprometimento organizacional foi composto por questões que abordavam: i) comprometimento afetivo, traduzido em forte crença e aceitação dos valores e objetivos da organização; forte desejo de manter o vínculo com a organização e intenção de se esforçar em prol da organização; ii) instrumental, referindo-se a um comprometimento percebido como custos associados por deixar a organização; e iii) normativo, refletindo um sentimento de obrigação de permanecer na organização. A tabela 2, a seguir, aponta algumas questões abordadas sobre comprometimento.

Tabela $n^{0} 2$ - Questões referentes à variável comprometimento. Empresa A, Cabo Verde, 2008

\begin{tabular}{|c|c|c|c|}
\hline Perguntas & Alternativa & $\mathbf{N}$ & $\%$ \\
\hline \multicolumn{4}{|l|}{ Dimensão Afetiva } \\
\hline \multirow[t]{4}{*}{ P6 - Eu concordo com as práticas adotadas pela minha empresa } & Concordo totalmente & 9 & 9,2 \\
\hline & Concordo & 67 & 68,4 \\
\hline & Discordo & 20 & 20,4 \\
\hline & Discordo totalmente & 2 & 2,0 \\
\hline \multirow[t]{4}{*}{ P8 - Eu acredito nos valores e objetivos desta empresa. } & Concordo totalmente & 33 & 33,7 \\
\hline & Concordo & 55 & 56,1 \\
\hline & Discordo & 9 & 9,2 \\
\hline & Discordo totalmente & 1 & 1,0 \\
\hline \multirow[t]{4}{*}{ P10 - Eu me esforço para que a empresa atinja os seus objetivos } & Concordo totalmente & 66 & 67,4 \\
\hline & Concordo & 30 & 30,6 \\
\hline & Discordo & 2 & 2,0 \\
\hline & Discordo totalmente & 0 & 0 \\
\hline \multirow{4}{*}{$\begin{array}{l}\text { P19- Conversando com os amigos, eu sempre me refiro à minha } \\
\text { empresa como uma grande instituição para a qual eu me orgulho } \\
\text { em trabalhar. }\end{array}$} & Concordo totalmente & 50 & 51,0 \\
\hline & Concordo & 43 & 43,9 \\
\hline & Discordo & 5 & 5,1 \\
\hline & Discordo totalmente & 0 & 0 \\
\hline \multirow{4}{*}{$\begin{array}{l}\text { P39- Sinto-me comprometido com a Visão, Missão, Objetivos e } \\
\text { estratégias da empresa. }\end{array}$} & Concordo totalmente & 34 & 34,7 \\
\hline & Concordo & 57 & 58,2 \\
\hline & Discordo & 7 & 7,1 \\
\hline & Discordo totalmente & 0 & 0 \\
\hline \multirow[t]{4}{*}{ P46- Identifico-me com a filosofia desta empresa. } & Concordo totalmente & 19 & 19,4 \\
\hline & Concordo & 61 & 62,2 \\
\hline & Discordo & 17 & 17,4 \\
\hline & Discordo totalmente & 1 & 1,0 \\
\hline
\end{tabular}


Tabela $\mathbf{n}^{0} 2$ - Questões referentes à variável comprometimento. Empresa A, Cabo Verde, 2008

\begin{tabular}{|c|c|c|c|}
\hline & & \multicolumn{2}{|c|}{ (continuação } \\
\hline Perguntas & Alternativa & $\mathrm{N}$ & $\%$ \\
\hline \multicolumn{4}{|l|}{ Dimensão Normativa } \\
\hline \multirow[t]{4}{*}{ P35 - Empregado tem a obrigação de sempre cumprir suas tarefas. } & Concordo totalmente & 29 & 29,6 \\
\hline & Concordo & 59 & 60,2 \\
\hline & Discordo & 10 & 10,2 \\
\hline & Discordo totalmente & 0 & 0 \\
\hline \multirow{4}{*}{$\begin{array}{l}\text { P37 - Uma das coisas mais importantes na empresa é cumprir suas } \\
\text { normas e regulamentos. }\end{array}$} & Concordo totalmente & 25 & 25,5 \\
\hline & Concordo & 57 & 58,2 \\
\hline & Discordo & 16 & 16,3 \\
\hline & Discordo totalmente & 0 & 0 \\
\hline \multirow{4}{*}{$\begin{array}{l}\text { P43 - O bom empregado deve dedicar-se de corpo e alma para a } \\
\text { sua empresa. }\end{array}$} & Concordo totalmente & 49 & 50,0 \\
\hline & Concordo & 44 & 44,9 \\
\hline & Discordo & 5 & 5,1 \\
\hline & Discordo totalmente & 0 & 0 \\
\hline \multirow{4}{*}{$\begin{array}{l}\text { P47 - Eu tenho obrigação em desempenhar bem a minha função } \\
\text { na empresa. }\end{array}$} & Concordo totalmente & 51 & 52,0 \\
\hline & Concordo & 46 & 46,9 \\
\hline & Discordo & 1 & 1,1 \\
\hline & Discordo totalmente & 0 & 0 \\
\hline \multirow{4}{*}{$\begin{array}{l}\text { P51 - Eu não sinto nenhuma obrigação em permanecer nesta } \\
\text { empresa. }\end{array}$} & Concordo totalmente & 2 & 2,0 \\
\hline & Concordo & 33 & 33,7 \\
\hline & Discordo & 43 & 43,9 \\
\hline & Discordo totalmente & 20 & 20,4 \\
\hline \multirow{4}{*}{$\begin{array}{l}\text { P53 - O bom desempenho na empresa é uma decorrência de } \\
\text { sempre respeitar suas regras. }\end{array}$} & Concordo totalmente & 19 & 19,4 \\
\hline & Concordo & 54 & 55,1 \\
\hline & Discordo & 22 & 22,5 \\
\hline & Discordo totalmente & 3 & 3,0 \\
\hline \multicolumn{4}{|l|}{ Dimensão Instrumental } \\
\hline \multirow{4}{*}{$\begin{array}{l}\text { P23 - Para manter-me na empresa, procuro fazer sempre o que é } \\
\text { esperado de mim. }\end{array}$} & Concordo totalmente & 45 & 45,9 \\
\hline & Concordo & 45 & 45,9 \\
\hline & Discordo & 8 & 8,2 \\
\hline & Discordo totalmente & 0 & 0 \\
\hline \multirow{4}{*}{$\begin{array}{l}\text { P25 - Procuro não transgredir as regras aqui, pois assim manterei } \\
\text { o meu trabalho. }\end{array}$} & Concordo totalmente & 35 & 35,7 \\
\hline & Concordo & 46 & 46,9 \\
\hline & Discordo & 15 & 15,3 \\
\hline & Discordo totalmente & 2 & 2,1 \\
\hline \multirow[t]{4}{*}{ P27 - É importante realizar, naturalmente, o trabalho solicitado. } & Concordo totalmente & 46 & 46,9 \\
\hline & Concordo & 50 & 51,0 \\
\hline & Discordo & 2 & 2,1 \\
\hline & Discordo totalmente & 0 & 0 \\
\hline \multirow{4}{*}{$\begin{array}{l}\text { P29- Se todos fizessem sempre o necessário não haveria } \\
\text { demissões na empresa. }\end{array}$} & Concordo totalmente & 21 & 21,4 \\
\hline & Concordo & 33 & 33,7 \\
\hline & Discordo & 37 & 37,8 \\
\hline & Discordo totalmente & 7 & 7,1 \\
\hline \multirow{4}{*}{$\begin{array}{l}\text { P31- Não gostaria de deixar minha empresa, já que investi } \\
\text { bastante da minha vida aqui. }\end{array}$} & Concordo totalmente & 30 & 30,6 \\
\hline & Concordo & 40 & 40,8 \\
\hline & Discordo & 28 & 28,6 \\
\hline & Discordo totalmente & 0 & 0,0 \\
\hline \multirow{4}{*}{$\begin{array}{l}\text { P33- Esta empresa me dá benefícios que dificilmente encontraria } \\
\text { em outro local. }\end{array}$} & Concordo totalmente & 15 & 15,3 \\
\hline & Concordo & 50 & 51,0 \\
\hline & Discordo & 30 & 30,6 \\
\hline & Discordo totalmente & 3 & 3,1 \\
\hline
\end{tabular}

Entende-se que a maior parte dos entrevistados concorda, em quase todas as questões, que são comprometidos. Os respondentes concordaram em média 89\%,84\% e 79\%, respectivamente, 
no que se refere às dimensões afetiva, normativa e instrumentalmente. Os resultados demonstraram também que a maioria aceita os valores da empresa, 90\%; que existe um forte desejo de manter vínculo com a organização, 95\%, e de que existe a intenção de se esforçar em prol da organização, 98\%. Também houve uma percepção significativa, 66\%, de que a empresa dá benefícios que dificilmente encontra em outras organizações, e de que deve participar e dedicar-se de corpo e alma à empresa, $95 \%$.

Em relação à dimensão instrumental, em média, 79\% dos respondentes afirmaram ser comprometidos, porém 34\% dos respondentes discordaram que a empresa lhes dá benefícios que dificilmente encontraria em outra empresa.

Na opinião do Administrador Executivo os colaboradores têm orgulho de pertencer à empresa. "Os colaboradores têm orgulho de pertencer a esta empresa. Isso temos recolhido até nos inquéritos e é provado pela taxa de rotatividade. Praticamente não temos, as pessoas não saem dessa empresa” (ADMINISTRADOR EXECUTIVO DA EMPRESA A).

O Administrador Executivo afirma que existe comprometimento, mas muito fraco, o que se contradiz com a opinião dos colaboradores que concordam serem comprometidos afetiva, normativa e instrumentalmente. Essa opinião é expressa na fala a seguir:

A questão do comprometimento é uma luta permanente devido às lacunas que ainda persistem nomeadamente em relação à atitude. Existe, com todo trabalho de sensibilização que nós fazemos de explicar às pessoas que é preciso trabalhar, que as condições não caem do céu, que devemos satisfazer os clientes, os acionistas, sermos eficientes para reduzirmos os custos. Há todo esse trabalho, por isso há algum comprometimento. As pessoas não estão de costas voltadas para a empresa, agora notase, por exemplo, que há umas ações desenvolvidas, de discussão de temas, reuniões, espaço social (...). A empresa consegue os resultados por causa dos colaboradores, por isso há um comprometimento só que eu sou muito exigente e gostaria que fosse maior. As pessoas estão engajadas, não no nível eu gostaria (ADMINISTRADOR EXECUTIVO DA EMPRESA A).

Já a Diretora de Recursos Humanos tem opinião diferente da do Administrador Executivo no que se refere ao comprometimento dos colaboradores, ao declarar que: "é claro que em qualquer empresa há aqueles que são mais comprometidos e aqueles que são menos, mas no total acredito que os trabalhadores do grupo são comprometidos. Acredito que porque estão numa 
empresa que é o que é e porque estão a fazer o que gostam de fazer" (DIRETORA DE RECURSOS HUMANOS DA EMPRESA A).

No entanto, em relação aos motivos desse comprometimento, todos os entrevistados compartilham da mesma opinião, expressa nos trechos a seguir:

De uma forma geral estão todos satisfeitos, conseguem por estarem aqui ter sem dúvida nenhuma as suas necessidades básicas satisfeitas, tem garantia de um salário mensal no mesmo dia de cada mês, o que com muito orgulho digo que nunca falhou, a empresa tem a estabilidade que tem, tem os benefícios que tem, é a empresa que no mercado nacional não vejo motivo para as pessoas não estarem satisfeitas. É claro que estou a falar de uma forma global, porque podem haver pessoas que digam de forma contrária. $\mathrm{O}$ entendimento que temos é que temos uma empresa estável com funcionários amigo dos outros (DIRETORA DE RECURSOS HUMANOS DA EMPRESA A).

(...) Eu penso que as pessoas sentem orgulho, umas porque gostam, outras por interesse, é uma das maiores de Cabo Verde, mais consolidada, que dá mais garantia, melhores condições de trabalho e remuneração. Portanto há diverso fator que leva as pessoas a terem orgulho dessa empresa. Há aqueles que tem de coração, eu não me viria noutra empresa. Tenho muitos colegas que já estão aqui há 15 anos e têm amor, há aqueles que podem não ter amor, mas por inércia vão adquirindo amor... É uma empresa de oportunidades, que apresenta condições e possibilidades de trabalho, remuneração, todo mundo tem chance de subir na empresa e chegar a diretor. Pode entrar como quadro superior, daqui a três meses existe um concurso para gestor que é nível acima podes concorrer. É uma empresa de oportunidades que oferece possibilidade da pessoa fazer uma carreira (ADMINISTRADOR EXECUTIVO DA EMPRESA).

(...) A empresa é referência no país, tem subsídio de férias, subsídio de natal, subsídio de produtividade etc. Tem $\mathrm{x}$ impulsos a gastar durante um ano, nacional e internacional, dependendo do cargo, a pessoa tem acesso a telemóvel, benefícios, TV a cabo, ZAP, em casa (DIRETORA DO GABINETE DE COMUNICACÃO E IMAGEM DA EMPRESA A).

As pessoas entrevistadas (Diretora do Gabinete de Comunicação e Imagem; Diretora de Recursos Humanos e Administrador Executivo) declararam que os colaboradores permanecem na empresa devido aos benefícios, salário que a empresa oferece, levando a crer que o comprometimento existente é o instrumental, percepção essa que não é confirmada pelos colaboradores abordados na pesquisa quantitativa que concordam em média, 89\% que são comprometidos afetivamente, seguida do comprometimento normativa com $84 \%$. $\mathrm{O}$ comprometimento instrumental veio por último com $79 \%$, em média, de concordância.

De acordo com as entrevistas a empresa adota uma estratégia e controle em detrimento da estratégia de comprometimento. Isso fica evidente nas declarações a seguir: 
Temos o sistema de controle de entrada e saída dos funcionários, ao entrar e sair da empresa, as ausências justificadas ou não pelas chefias, são corrigidas se não for é descontado no salário automaticamente. As pessoas têm que cumprir os horários de trabalho, a assiduidade é fundamental.

(...) Qualquer um que entra no grupo, estando no quadro, a empresa tem um plano de carreiras que é praticamente administrativo, porque exige um nível de antiguidade no nível e resultado de avaliação profissional satisfatório. Tendo esses requisitos cumpridos, o tempo de estar no nível são três anos, ao fim desses três anos a empresa avalia se esse requisito foi cumprido e é feito uma progressão. A pessoa vai andando no seu nível de técnico ou quadro superior ou aquilo que for. Para além disso, existe os concursos internos que são feitos, que permitem a quem tiver requisitos mudar de área, escolher o seu próprio caminho dentro da área. Além disso, a empresa lança concurso interno para cargo de chefia e se o colaborador entender que tem requisitos para concorrer concorre, é uma outra hipótese de fazer carreira dentro da empresa.

(...) A nível de remuneração há uma tabela de remuneração dependendo do nível e da categoria profissional a pessoa aufere de um salário. Em relação aos incentivos temos o prêmio anual que vem sempre decidido pela assembléia geral, desde a criação da empresa. Temos o prêmio especial de qualidade que surgiu no âmbito do projeto qualidade e continua e que é distribuído anualmente a cada diretor e este, de acordo com o regulamento, atribuiu aos seus colaboradores; quem merecer o prêmio, não é a todos. Há outras gratificações que a empresa vai decidindo dar de acordo com atribuições específicas que são feitas. (...) A remuneração é fixa, com base na tabela salarial de acordo com a categoria que a pessoa desempenha.

(...) Quem faz todo o processo de contratação é o RH. Existe um levantamento da ficha de perfil pela chefia da área que tem vaga e encaminha para o RH e nós fazemos a abertura da candidatura. Tendo os candidatos fazemos a análise curricular. Quando temos postos de trabalho que exigem competências técnicas muito especificas, o responsável da área que tem a vaga entra conosco na análise curricular e as outras fases da contratação são feitas por nós e na fase específica nomeadamente processo de entrevista estamos nós com a responsável da vaga para avaliação das competências técnicas. O resto está tudo a cargo do RH (DIRETORA DE RECURSOS HUMANOS DA EMPRESA A).

Fica evidente que a estratégia adotada pela empresa tende a ser mais a de controle, pois existe um controle rígido com entrada e saída dos colaboradores; a progressão e promoção têm como base o tempo de permanência na empresa; a remuneração é fixa, embora tenha bônus que alguns colaboradores podem ganhar, é o departamento de RH responsável para toda a contratação do pessoal. 


\subsection{Análise descritiva da empresa B - Brasil}

Os 195 respondentes representam cerca de 21,0\% dos questionários enviados (900) e cerca de 3,0\% da população (6000). Dentre os respondentes encontrou-se 63,6\% de homens e 36,4\% de mulheres; $75,9 \%$ dos respondentes têm entre 26 e 45 anos de idade; mais do que metade $(54,4 \%)$ tem mais de 6 anos de serviço; 86,1\% dos respondentes tem nível superior completo, sendo que o resto se divide em $13,9 \%$ com nível médio; $37,9 \%$ solteiro, $60,0 \%$ casado; $57,4 \%$ tem filhos.

\subsubsection{Aspectos sobre a comunicação interna:}

As variáveis que compreendem este consctructo têm como objetivo descrever como funciona o processo comunicativo dentro da organização. A tabela 3, a seguir, realça alguns resultados. Entende-se que os participantes concordaram que o processo comunicativo dentro da empresa permite a comunicação em todas as direções, mediante vários meios, redes e fluxos, com concordância superiores a $88 \%$ em todas as questões. Um outro aspecto bastante positivo da comunicação planejada é a elevada porcentagem (77\%) das pessoas que participam de decisões que afetam os seus trabalhos. Em relação a algumas questões que foram formuladas na forma negativa, como por exemplo, - eu não recebo informações de outros setores/ departamentos da empresa - percebe-se a concentração das respostas em discordo, com 53\%. A existência de vários canais e meios de comunicação utilizados são percebidos pela maioria, 79\%. Quando perguntado se o processo de comunicação interna é eficiente, eficaz e satisfatório 70\% concordaram. Para que a área de comunicação ocupe uma posição estratégica dentro da organização deve existir uma área ou departamento que planeja a comunicação e esta deve ser planejada pensada e administrada estrategicamente. Existe a percepção da maioria, 77\%, de que existe essa área e que ela ocupa um espaço estratégico. Em relação a algumas questões que foram formuladas na forma negativa, como por exemplo - a área de comunicação, nesta empresa, só funciona para resolver problemas em momentos de crise - observou-se a concentração nas discordâncias (87\%). 


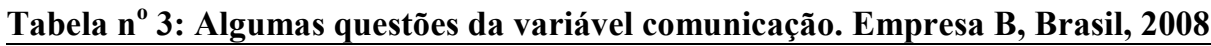

\begin{tabular}{|c|c|c|c|}
\hline Perguntas & Alternativa & $\mathbf{n}$ & $\%$ \\
\hline \multirow[t]{4}{*}{ P5- A empresa permite a comunicação entre ela e os funcionários } & Concordo totalmente & 51 & 26,2 \\
\hline & Concordo & 128 & 65,6 \\
\hline & Discordo & 12 & 6,2 \\
\hline & Discordo totalmente & 4 & 2,1 \\
\hline \multirow{4}{*}{$\begin{array}{l}\text { P7- Nesta empresa a comunicação prioritária é a de baixo para } \\
\text { cima. }\end{array}$} & Concordo totalmente & 9 & 4,6 \\
\hline & Concordo & 34 & 17,4 \\
\hline & Discordo & 110 & 56,4 \\
\hline & Discordo totalmente & 42 & 21,5 \\
\hline \multirow{4}{*}{$\begin{array}{l}\text { P9- Nesta empresa a comunicação é vista como importante para o } \\
\text { bom funcionamento do negócio. }\end{array}$} & Concordo totalmente & 67 & 34,4 \\
\hline & Concordo & 104 & 53,3 \\
\hline & Discordo & 21 & 10,8 \\
\hline & Discordo totalmente & 3 & 1,5 \\
\hline \multirow{4}{*}{$\begin{array}{l}\text { P11- Existem canais que permitem comunicação com os } \\
\text { funcionários de todos os níveis. }\end{array}$} & Concordo totalmente & 68 & 34,9 \\
\hline & Concordo & 86 & 44,1 \\
\hline & Discordo & 32 & 16,4 \\
\hline & Discordo totalmente & 9 & 4,6 \\
\hline \multirow{4}{*}{$\begin{array}{l}\text { P15- Eu não recebo informações de outros setores/ departamentos } \\
\text { da empresa. }\end{array}$} & Concordo totalmente & 19 & 9,7 \\
\hline & Concordo & 73 & 37,4 \\
\hline & Discordo & 77 & 39,5 \\
\hline & Discordo totalmente & 26 & 13,4 \\
\hline \multirow{4}{*}{$\begin{array}{l}\text { P22- Nesta empresa existem mecanismos que me permitem falar } \\
\text { com meus superiores diretos, indiretos e colegas. }\end{array}$} & Concordo totalmente & 67 & 34,4 \\
\hline & Concordo & 105 & 53,9 \\
\hline & Discordo & 18 & 9,2 \\
\hline & Discordo totalmente & 5 & 2,6 \\
\hline \multirow{4}{*}{$\begin{array}{l}\text { P24- Tenho oportunidade de participar de decisões que afetam o } \\
\text { meu trabalho. }\end{array}$} & Concordo totalmente & 54 & 27,7 \\
\hline & Concordo & 95 & 48,7 \\
\hline & Discordo & 36 & 18,5 \\
\hline & Discordo totalmente & 10 & 5,1 \\
\hline \multirow[t]{4}{*}{ P28- Sou informado (a) sobre o que se passa dentro da empresa. } & Concordo totalmente & 31 & 15,9 \\
\hline & Concordo & 115 & 59,0 \\
\hline & Discordo & 46 & 23,6 \\
\hline & Discordo totalmente & 3 & 1,5 \\
\hline \multirow{4}{*}{$\begin{array}{l}\text { P32- A área de comunicação, nesta empresa, só funciona para } \\
\text { resolver problemas em momentos de crise. }\end{array}$} & Concordo totalmente & 9 & 4,6 \\
\hline & Concordo & 29 & 14,9 \\
\hline & Discordo & 144 & 58,5 \\
\hline & Discordo totalmente & 43 & 28,0 \\
\hline \multirow{4}{*}{$\begin{array}{l}\text { P36- As estratégias de comunicação, nesta empresa, são traçadas a } \\
\text { partir da visão, missão, valores da empresa, visando o alcance de } \\
\text { resultados. }\end{array}$} & Concordo totalmente & 52 & 26,7 \\
\hline & Concordo & 111 & 56,9 \\
\hline & Discordo & 29 & 14,9 \\
\hline & Discordo totalmente & 3 & 1,5 \\
\hline \multirow{4}{*}{$\begin{array}{l}\text { P38 - A área de comunicação, nesta empresa, é planejada, } \\
\text { pensada e administrada estrategicamente. }\end{array}$} & Concordo totalmente & 25 & 12,8 \\
\hline & Concordo & 134 & 68,7 \\
\hline & Discordo & 32 & 16,4 \\
\hline & Discordo totalmente & 4 & 2,1 \\
\hline \multirow{4}{*}{$\begin{array}{l}\text { P40- O processo de comunicação nesta empresa promove a } \\
\text { integração entre os diferentes setores/ departamentos }\end{array}$} & Concordo totalmente & 28 & 14,4 \\
\hline & Concordo & 94 & 48,1 \\
\hline & Discordo & 62 & 31,8 \\
\hline & Discordo totalmente & 11 & 5,6 \\
\hline \multirow{4}{*}{$\begin{array}{l}\text { P42- A comunicação, nesta empresa, ocupa um espaço estratégico } \\
\text { na estrutura organizacional. }\end{array}$} & Concordo totalmente & 42 & 21,5 \\
\hline & Concordo & 109 & 55,9 \\
\hline & Discordo & 41 & 21,3 \\
\hline & Discordo totalmente & 3 & 1,5 \\
\hline \multirow{4}{*}{$\begin{array}{l}\text { P48- Eu recebo feedback dos meus superiores sobre o } \\
\text { desempenho das minhas funções. }\end{array}$} & Concordo totalmente & 56 & 28,7 \\
\hline & Concordo & 92 & 47,2 \\
\hline & Discordo & 33 & 16,9 \\
\hline & Discordo totalmente & 14 & 7,8 \\
\hline
\end{tabular}


Tabela n 3: Algumas questões da variável comunicação. Empresa B, Brasil, 2008

\begin{tabular}{llcc} 
& \multicolumn{2}{c}{ (continuação) } \\
\hline \multicolumn{1}{c}{ Perguntas } & \multicolumn{1}{c}{ Alternativa } & n & \% \\
\hline P50- O processo de comunicação interna é eficiente, eficaz e & Concordo totalmente & 34 & 17,4 \\
satisfatório. & Concordo & 102 & 52,3 \\
& Discordo & 49 & 23,1 \\
& Discordo totalmente & 10 & 5,2 \\
\hline
\end{tabular}

Percebe-se que o processo comunicativo na organização funciona, utilizando vários meios e redes formais e informais. Os fluxos de informação permitem a comunicação com chefias, pares e subordinados. Apesar dos respondentes perceberem que existe uma área de comunicação dentro da empresa, que ela é planejada e administrada estrategicamente assim como a importância da mesma para a organização, uma parte significativa dos respondentes, 48\%, afirma não receber informações de outros setores ou departamentos da empresa.

Nas entrevistas com o Diretor de Comunicação e Relações Corporativas e Gerente de RH fica evidente a importância da comunicação interna dentro da empresa, até pela sua posição na estrutura organizacional, subordinada à Diretoria Executiva de Relações Institucionais, ligada à Presidência da empresa. Ainda, segundo o respectivo diretor, a área de comunicação ocupa um espaço estratégico na estrutura organizacional ao confirmar que "a comunicação é envolvida no processo de tomada de decisões da companhia" (DIRETOR DE COMUNICAÇÃO E RELAÇÕES CORPORATIVAS DA EMPRESA B). A Gerente de RH confirma essa percepção ao declarar que:

É a comunicação, tanto a institucional quanto a realizada no dia a dia pelo gestor, que conecta as pessoas à estratégia. $\mathrm{O}$ alinhamento cultural e a disseminação dos valores da empresa se dão pela comunicação. ... Investimos pesadamente (...) na comunicação. Sempre realizamos reuniões para falarmos de resultados e de acompanhamento dos projetos estratégicos da empresa e todos os gestores têm que desdobrá-los para as suas equipes (GERENTE DE RH DA EMPRESA B).

A percepção do respectivo diretor reforça a percepção dos colaboradores pesquisados, pois uma maioria significativa, 87\%, concordaram quanto à ocupação da comunicação de um espaço estratégico dentro da organização.

O diretor de comunicação e relações corporativas deixa transparecer que a comunicação interna é eficaz, ao declarar que: 
Uma vez por mês, o Presidente da empresa se reúne com um grupo de 15 empregados para um café da manhã. Nesses encontros, os profissionais podem falar abertamente sobre estratégias da companhia e tirar dúvidas diretamente com o principal executivo da companhia. Além disso, o Diretor Geral da empresa, também realiza encontros com jovens profissionais para falar sobre carreira. (...) Existe uma grande preocupação da empresa em fazer com que todos os funcionários conheçam o negócio da empresa como um todo. Após todas as reuniões com executivos para apresentação de estratégias ou resultados, os executivos são orientados a repassar informações para suas equipes. Após essa etapa, são feitas pesquisas com os empregados para verificar se as informações foram repassadas e se foram compreendidas. (...) Há pelo menos duas oportunidades de feedback formal e individual para os profissionais da equipe: no momento da avaliação de salários e também do pagamento do bônus. Mas além dessas oportunidades, os gestores da área de comunicação dão feedback sempre que necessário, tanto para elogiar quanto para apontar pontos de melhoria para as equipes. (...) Temos nos empenhado em manter a transparência, discutindo a estratégia de atuação com toda a equipe. Temos uma reunião de pauta semanal em que debatemos os principais temas da agenda e que é um momento em que todos podem opinar e dar sugestões (DIRETOR DE COMUNICAÇÃO E RELAÇÕES CORPORATIVAS DA EMPRESA B).

No que tange à existência de comunicação integrada, o Diretor de Comunicação e Relações Corporativas entende que existe. Alguns trechos da entrevista, a seguir, relatam esse entendimento.

A Diretoria Executiva de Relações Institucionais tem entre suas atividades a Diretoria de Comunicação e também as Diretorias de Marketing Institucional, Assuntos Institucionais, Assuntos Corporativos e Regulamentação. Essa estrutura possibilita a integração do discurso da companhia para todos os seus públicos, seja nas campanhas de mídia, nos contatos com jornalistas, autoridades, órgão regulador e também com o público interno (DIRETOR DE COMUNICAÇÃO E RELAÇÕES CORPORATIVAS DA EMPRESA B).

Em relação ao compartilhamento de informações entre setores/ departamentos da empresa, 48\% dos colaboradores abordados na pesquisa quantitativa discordaram. Essa percepção é reforçada quando $37 \%$ dos respondentes da pesquisa quantitativa também declararam que o processo de comunicação não promove a integração entre os diferentes setores/ departamentos.

No que se refere à existência de uma política de comunicação interna, o Diretor de Comunicação e Relações Corporativas concordou que sim, declarando que a Diretoria de Comunicação tem entre suas atribuições a comunicação interna que tem como objetivo fazer chegar as informações a todos os colaboradores. Os excertos, a seguir, demonstram a existência de tal política: 
A companhia tem tentado garantir que as informações discutidas pela cúpula cheguem a todos os profissionais. Para isso, após reuniões com executivos para avaliação de resultados ou definição de estratégias, a área de Recursos Humanos envia um "kit" com informações que devem ser repassadas às equipes. Posteriormente, a Comunicação Interna disponibiliza uma pesquisa para que os profissionais avaliem a qualidade da informação recebida. (...) Desde 2007, o presidente da empresa participa de cafés da manhã com grupos de trabalhadores. Os empregados podem se inscrever pela intranet $\mathrm{e}$ têm a oportunidade de conversar com o presidente sobre a estratégia da companhia... Os endereços de e-mail e telefones de todos os profissionais estão disponíveis na intranet da empresa, facilitando os contatos (DIRETOR DE COMUNICAÇÃO E RELAÇÕES CORPORATIVAS DA EMPRESA B).

\subsubsection{Aspectos sobre comprometimento organizacional:}

O constructo comprometimento organizacional foi composto por questões que abordavam os seguintes componentes: i) comprometimento afetivo, traduzido em forte crença e aceitação dos valores e objetivos da organização; forte desejo de manter o vínculo com a organização e intenção de se esforçar em prol da organização; ii) instrumental, referindo-se a um comprometimento percebido como custos associados por deixar a organização; e iii) normativo, refletindo um sentimento de obrigação de permanecer na organização. A tabela 4, a seguir, apresenta algumas questões abordadas sobre esta variável.

Tabela $n^{0} 4$ - Questões referentes à variável comprometimento. Empresa B, Brasil, 2008

\begin{tabular}{|c|c|c|c|}
\hline Perguntas & Alternativa & n & $\%$ \\
\hline \multicolumn{4}{|l|}{ Dimensão Afetiva } \\
\hline \multirow{4}{*}{$\begin{array}{l}\text { P6 - Eu concordo com as práticas adotadas pela minha } \\
\text { empresa }\end{array}$} & Concordo totalmente & 34 & 17,5 \\
\hline & Concordo & 136 & 70,1 \\
\hline & Discordo & 24 & 12,4 \\
\hline & Discordo totalmente & 0 & 0 \\
\hline \multirow[t]{4}{*}{ P8 - Eu acredito nos valores e objetivos desta empresa. } & Concordo totalmente & 56 & 28,7 \\
\hline & Concordo & 121 & 52,1 \\
\hline & Discordo & 15 & 7,7 \\
\hline & Discordo totalmente & 3 & 1,5 \\
\hline \multirow{4}{*}{$\begin{array}{l}\text { P10 - Eu me esforço para que a empresa atinja os seus } \\
\text { objetivos }\end{array}$} & Concordo totalmente & 146 & 74,9 \\
\hline & Concordo & 47 & 24,1 \\
\hline & Discordo & 1 & 0,5 \\
\hline & Discordo totalmente & 1 & 0,5 \\
\hline \multirow{4}{*}{$\begin{array}{l}\text { P19- Conversando com os amigos, eu sempre me refiro à } \\
\text { minha empresa como uma grande instituição para a qual eu } \\
\text { me orgulho em trabalhar. }\end{array}$} & Concordo totalmente & 68 & 35,9 \\
\hline & Concordo & 109 & 55,9 \\
\hline & Discordo & 15 & 7,8 \\
\hline & Discordo totalmente & 3 & 1,5 \\
\hline
\end{tabular}


Tabela nº 4 - Questões referentes à variável comprometimento. Empresa B, Brasil, 2008

\begin{tabular}{|c|c|c|c|}
\hline & & & nuaçã \\
\hline Perguntas & Alternativa & $\mathbf{n}$ & $\%$ \\
\hline Dimensão Afetiva & & & \\
\hline P39- Sinto-me comprometido com a Visão, Missão, & Concordo totalmente & 77 & 39,5 \\
\hline Objetivos e Estratégias da empresa. & Concordo & 100 & 51,3 \\
\hline & Discordo & 17 & 8,7 \\
\hline & Discordo totalmente & 1 & 0,5 \\
\hline P46- Identifico-me com a filosofia desta empresa. & Concordo totalmente & 27 & 13,9 \\
\hline & Concordo & 137 & 70,3 \\
\hline & Discordo & 28 & 14,4 \\
\hline & Discordo totalmente & 3 & 1,5 \\
\hline Dimensão Normativa & & & \\
\hline P35 - Empregado tem a obrigação de sempre cumprir suas & Concordo totalmente & 50 & 25,6 \\
\hline tarefas. & Concordo & 115 & 58,9 \\
\hline & Discordo & 26 & 13,3 \\
\hline & Discordo totalmente & 4 & 2,2 \\
\hline P37 - Uma das coisas mais importantes na empresa é & Concordo totalmente & 33 & 16,9 \\
\hline cumprir suas normas e regulamentos. & Concordo & 119 & 61,0 \\
\hline & Discordo & 40 & 20,5 \\
\hline & Discordo totalmente & 3 & 1,6 \\
\hline P43 - O bom empregado deve dedicar-se de corpo e alma & Concordo totalmente & 39 & 20,0 \\
\hline para a sua empresa. & Concordo & 98 & 50,3 \\
\hline & Discordo & 55 & 28,2 \\
\hline & Discordo totalmente & 3 & 1,5 \\
\hline P47 - Eu tenho obrigação em desempenhar bem a minha & Concordo totalmente & 87 & 44,6 \\
\hline função na empresa. & Concordo & 98 & 50,3 \\
\hline & Discordo & 6 & 3,0 \\
\hline & Discordo totalmente & 4 & 2,1 \\
\hline P51 - Eu não sinto nenhuma obrigação em permanecer & Concordo totalmente & 16 & 8,2 \\
\hline nesta empresa. & Concordo & 86 & 44,1 \\
\hline & Discordo & 61 & 32,3 \\
\hline & Discordo totalmente & 32 & 16,4 \\
\hline P53 - O bom desempenho na empresa é uma decorrência de & Concordo totalmente & 28 & 14,4 \\
\hline sempre respeitar suas regras. & Concordo & 104 & 53,3 \\
\hline & Discordo & 56 & 28,7 \\
\hline & Discordo totalmente & 7 & 3,6 \\
\hline Dimensão Instrumental & & & \\
\hline P23 - Para manter-me na empresa, procuro fazer sempre o & Concordo totalmente & 90 & 46,2 \\
\hline que é esperado de mim. & Concordo & 90 & 46,2 \\
\hline & Discordo & 11 & 5,6 \\
\hline & Discordo totalmente & 4 & 2,0 \\
\hline P25 - Procuro não transgredir as regras aqui, pois assim & Concordo totalmente & 40 & 20,6 \\
\hline manterei o meu trabalho. & Concordo & 104 & 53,3 \\
\hline & Discordo & 42 & 21,5 \\
\hline & Discordo totalmente & 9 & 4,6 \\
\hline P27 - É importante realizar, naturalmente, o trabalho & Concordo totalmente & 82 & 42,1 \\
\hline solicitado. & Concordo & 106 & 54,4 \\
\hline & Discordo & 6 & 3,0 \\
\hline & Discordo totalmente & 1 & 0,5 \\
\hline P29- Se todos fizessem sempre o necessário não haveria & Concordo totalmente & 9 & 14,4 \\
\hline demissões na empresa. & Concordo & 37 & 53,3 \\
\hline & Discordo & 92 & 28,7 \\
\hline & Discordo totalmente & 57 & 3,6 \\
\hline
\end{tabular}


Tabela nº 4 - Questões referentes à variável comprometimento. Empresa B, Brasil, 2008

\begin{tabular}{llcc}
\hline Perguntas & Alternativa & (continuação) \\
\hline Dimensão Instrumental & & & \% \\
\hline P31- Não gostaria de deixar minha empresa, já que investi & Concordo totalmente & 53 & 27,2 \\
bastante da minha vida aqui. & Concordo & 83 & 42,6 \\
& Discordo & 52 & 26,7 \\
& Discordo totalmente & 7 & 3,6 \\
\hline P33- Esta empresa me dá benefícios que dificilmente & Concordo totalmente & 36 & 18,5 \\
encontraria em outro local. & Concordo & 90 & 46,2 \\
& Discordo & 57 & 29,2 \\
& Discordo totalmente & 12 & 6,0 \\
\hline
\end{tabular}

Verifica-se que a maior parte dos entrevistados concordou em quase todas as questões que são comprometidas afetiva, normativa e instrumentalmente. Em relação a estas dimensões, os respondentes concordaram em média $89 \%, 74 \%$ e 78\%, respectivamente. Os resultados indicam também que a maioria aceita os valores da empresa, $80 \%$; que existe um forte desejo de manter vínculo com a organização, 92\% e que existe a intenção de se esforçar em prol da organização, 99\%. Também houve uma percepção significativa, 65\%, de que a empresa dá benefícios que dificilmente encontra em outras organizações e de que deve participar e dedicar-se de corpo e alma à empresa, $70 \%$.

Embora os respondentes concordaram em média $76 \%$ que são comprometidos instrumentalmente, verifica-se que uma porcentagem significativa, 35\%, discordaram que a empresa lhes dá benefícios que dificilmente encontrariam em outra empresa. Em relação à dimensão normativa ainda que em média 74\% afirmaram ser comprometidos, $30 \%$ discordaram que um bom empregado deve dedicar-se de corpo e alma para a sua empresa.

Na opinião da Gerente de RH os colaboradores têm orgulho de pertencer à empresa. Essa percepção é relatada ao assegurar que:

Nossas pesquisas de clima apontam uma elevada satisfação de nossas equipes com relação a esse item. Entendo que seja por causa da solidez do grupo, de seu tamanho e valor (...) porque acreditamos no seu verdadeiro propósito de buscar a satisfação do cliente e de servir à sociedade.

$\mathrm{Na}$ empresa, traduzimos a visão e missão em causa, nossa causa é composta de dois objetivos muito claros: sermos os primeiros no mundo digital e os primeiros na escolha do cliente. Sentimo-nos, sim, comprometidos com essa causa, pois quem não quer fazer parte de um time vencedor e de uma empresa que contribui para o desenvolvimento da sociedade? Afinal o progresso que a tecnologia promove só tem sentido se for para o 
bem da sociedade, para que as pessoas vivam melhor e desfrutem do progresso (GERENTE DE RH DA EMPRESA B).

Essa opinião nos leva a crer que o comprometimento existente é instrumental e afetiva, percepção essa que não é confirmada pelos colaboradores abordados na pesquisa quantitativa que concordaram em média, $89 \%$ que são comprometidos afetivamente, seguida do comprometimento instrumental com $79 \%$ de concordância em média.

De acordo com a entrevista com a Gerente de RH, fica evidente que a empresa adota uma estratégia mais alinhada a de comprometimento. A seguir, alguns trechos da entrevista que confirmem tal estratégia:

Na maioria dos casos, os novos profissionais são selecionados por uma empresa do Grupo, que atua como shared services. Por fazer parte do Grupo, a empresa tem condições de selecionar pessoas com maior aderência aos valores e atitudes da companhia, além da competência técnica. As pessoas que querem trabalhar na empresa precisam compartilhar de seus valores e de sua cultura. Por isso, na entrevista por competências que se realiza para todos os níveis de posições, o processo seletivo explora as competências corporativas definidas pelo Grupo da empresa para assegurar que, além de conhecimento técnico e experiências desejadas, o candidato demonstre ter valores pessoais comuns aos da empresa. Todo parecer de candidato traz o grau de aderência observado em cada competência. São elas: Comunicação e Relações Transparentes; Flexibilidade; Compromisso com nossos Clientes; Contribuição para os Resultados; e Inovação. Queremos pessoas que não considerem que a empresa deve oferecer tudo. Nós oferecemos espaço para crescer. Mas o profissional é o principal responsável pela sua carreira. Assim, quando buscamos pessoas no mercado, nosso olhar é para profissionais que tenham fortes características de autonomia, responsabilidade e senso de protagonismo, e para tanto articulamos ações para incrementar nosso banco de currículos na busca desse DNA.

Tanto a política de Educação quanto a de Remuneração criam mecanismos e oferecem meios para as pessoas se desenvolverem e crescerem profissionalmente. Trabalhamos com o modelo de gestão por performance, em ambiente que favoreça a meritocracia. Para alcançar os objetivos organizacionais, o RH reviu todo o seu modelo, políticas, práticas e processos, de modo a sustentar o movimento de transformação. Era preciso fazer a ponte entre a mudança cultural e a melhoria do clima organizacional. Afinal, ambos devem caminhar juntos. $\mathrm{O}$ foco passou a ser 'encontrar as pessoas certas para $\mathrm{o}$ lugar certo com a motivação certa'. Desenvolvemos nossos líderes para que formem equipes de alta performance. Nossas ferramentas de avaliação de competências e de performance são ajustadas aos objetivos estratégicos da empresa.

As metas de negócio, que incluem indicadores de clima organizacional, estão presentes na composição das metas de todos os executivos e são comuns a todos eles e impactam nos bônus variáveis. ... As equipes também têm alguns desses objetivos em suas metas e também são avaliadas por elas. ... Realizamos pesquisas de clima durante todo ano e seus resultados são acompanhados de perto pela alta direção da empresa e por Recursos Humanos. Essas pesquisas são importantes instrumentos de direcionamento de nossos planos corporativos e de acompanhamento de nossas políticas de gestão de pessoas. 
No ano passado, nós reposicionamos a estratégia da empresa. Desenhamos, através de um triângulo muito simples, as três prioridades do negócio: liderança comercial, experiência do cliente e eficiência operacional. No centro do triângulo estão as pessoas. '....) A nossa estratégia posiciona as pessoas/ as equipes no centro como sustentação da mesma, pois é por meio das pessoas que realizamos a estratégia. Assim, a gestão de pessoas ganha em profundidade e fica alinhada à estratégia organizacional. $\mathrm{O}$ que colocamos como síntese de tudo isso é o engajamento das pessoas. Queremos que todos confiem no plano estratégico, que comprem o plano, e que reconheçam que esse é o melhor plano que podemos ter (GERENTE DE RH DA EMPRESA B).

Entende-se que a estratégia da empresa B tende a ser mais a de comprometimento, pois pelo menos em relação à política de RH a empresa dá possibilidade à pessoa de fazer sua carreira dentro da empresa; contrata para uma carreira longa dentro da empresa; o foco é nos incentivos grupais vinculados a resultados empresariais, focada no desempenho; a promoção e progressão não estão atrelados ao tempo de serviço na empresa; a remuneração não é fixa.

\subsection{Resultados dos fatores associados}

Entre os funcionários da empresa $\mathrm{A}$ foram observados as maiores freqüências de comprometimento entre os que se declararam casados, com idade acima de 35 anos, mais de cinco anos de serviço e boa comunicação (Tabela 5).

Para a empresa B foram observadas as maiores freqüências de comprometimento apenas entre aqueles com o curso médio completo e com boa comunicação (Tabela 6). 
Tabela $n^{0} 5$ - Freqüências e proporções de comprometimento, segundo características sociodemográficas e relativa à comunicação de funcionários de empresas de Telecomunicações. Empresa A, Cabo Verde, 2008.

$$
\text { Comprometimento }
$$

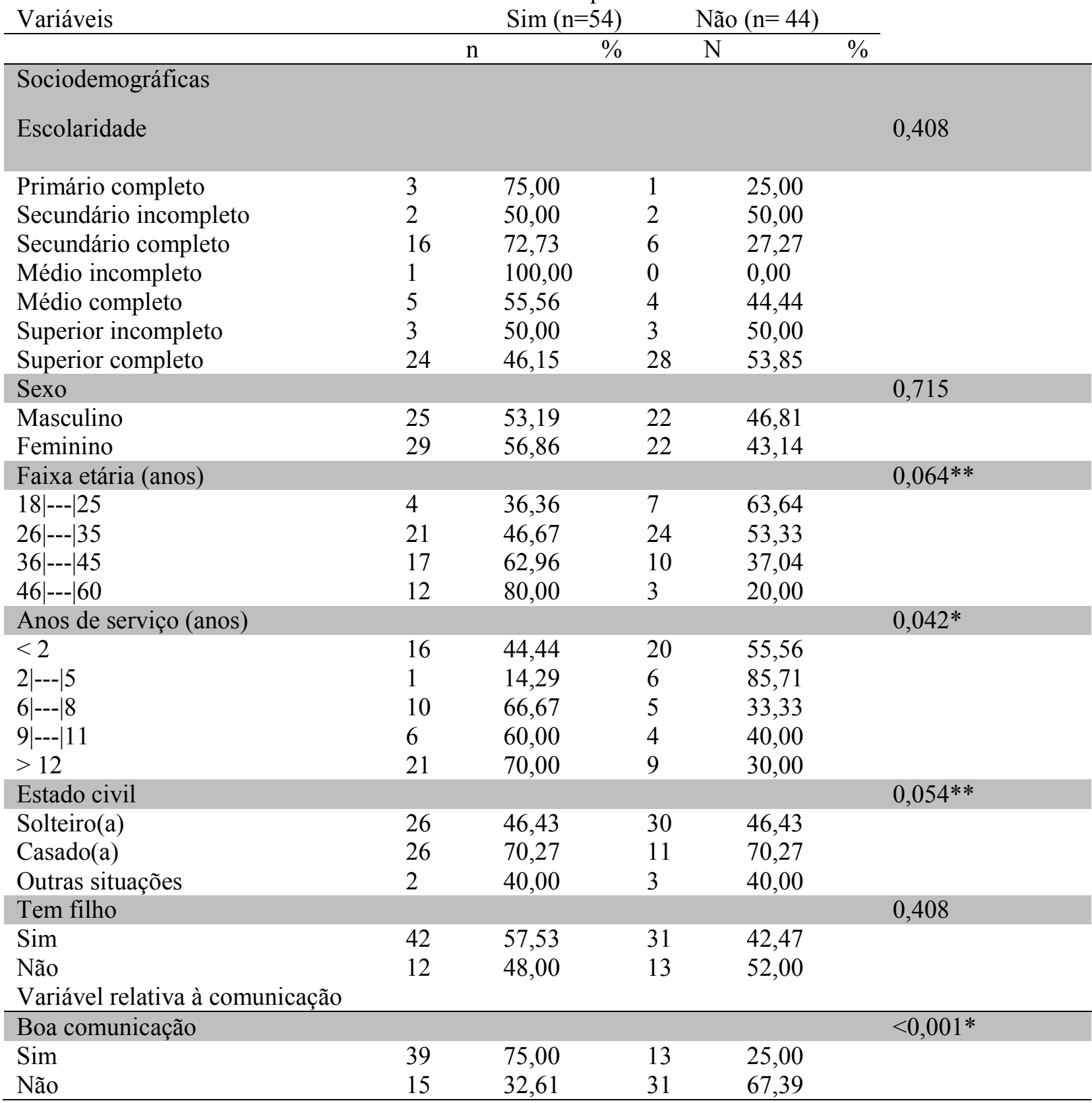

Notas:

* Diferenças significativas $\mathbf{p}<0,05 \mathrm{e}^{* *} \mathbf{p}<\mathbf{0 , 2 0}$ (teste pelo qui-quadrado ou Fisher, quando o qui-quadrado não for adequado).

*Condições para entrada no modelo múltiplos (tabela 7), p<0,20 no teste do qui-quadrado ou Fisher. 
Nas análises uni-variadas, verificou-se que boa comunicação, anos de serviço, estado civil, faixa etária e escolaridade estão associadas ao comprometimento, em nível de significância de $5 \%$ ou $10 \%$, conforme revelam as tabelas 5 e 6 .

Tabela $n^{0} 6$ - Freqüências e proporções de comprometimento, segundo características sociodemográficas e relativa à comunicação de funcionários de empresas de Telecomunicações. Empresa B, Brasil, 2008.

\begin{tabular}{|c|c|c|c|c|c|}
\hline \multirow{3}{*}{ Variáveis } & \multicolumn{4}{|c|}{ Comprometimento } & \multirow[t]{3}{*}{$\mathrm{P}$} \\
\hline & & \multicolumn{2}{|c|}{$\operatorname{Sim}(n=87)$} & Não (n= 107) & \\
\hline & & & $\%$ & $\mathrm{~N}$ & \\
\hline \multicolumn{6}{|l|}{ Sociodemográficas } \\
\hline Escolaridade & & & & & $0,065 * *$ \\
\hline Médio completo & 6 & 75,00 & 2 & 25,00 & \\
\hline Superior incompleto & 5 & 26,32 & 14 & 73,68 & \\
\hline Superior completo & 76 & 45,78 & 90 & 54,22 & \\
\hline Sexo & & & & & $0,187 * *$ \\
\hline Masculino & 60 & 48,39 & 64 & 51,61 & \\
\hline Feminino & 27 & 38,57 & 43 & 61,43 & \\
\hline Faixa etária (anos) & & & & & 0,249 \\
\hline $18|---| 25$ & 4 & 26,67 & 11 & 73,33 & \\
\hline $26|---| 35$ & 28 & 40,00 & 42 & 60,00 & \\
\hline $36|---| 45$ & 30 & 48,39 & 32 & 51,61 & \\
\hline $46|---| 60$ & 24 & 52,17 & 22 & 47,83 & \\
\hline$>60$ & 1 & 100,00 & 0 & 0,00 & \\
\hline Anos de serviço (anos) & & & & & $0,161 * *$ \\
\hline$<2$ & 10 & 34,48 & 19 & 65,52 & \\
\hline $2|---| 5$ & 20 & 40,00 & 30 & 60,00 & \\
\hline $6|---| 8$ & 11 & 42,31 & 15 & 57,69 & \\
\hline $9|---| 11$ & 6 & 33,33 & 12 & 66,67 & \\
\hline$>12$ & 40 & 56,34 & 31 & 43,66 & \\
\hline Estado civil & & & & & 0,485 \\
\hline Solteiro(a) & 29 & 39,73 & 44 & 60,27 & \\
\hline Casado(a) & 57 & 48,72 & 60 & 51,28 & \\
\hline Viúvo(a) & 1 & 33,33 & 2 & 66,67 & \\
\hline Outras situações & 0 & 0,00 & 1 & 100,00 & \\
\hline Tem filho & & & & & $0,163 * *$ \\
\hline Sim & 55 & 49,11 & 57 & 50,89 & \\
\hline Não & 32 & 39,02 & 50 & 60,98 & \\
\hline Boa comunicação & & & & & $<0,001^{*}$ \\
\hline $\operatorname{Sim}$ & 72 & 64,29 & 40 & 35,71 & \\
\hline Não & 15 & 18,29 & 67 & 81,71 & \\
\hline
\end{tabular}

Notas:

* Diferenças significativas $\mathbf{p}<0,05 \mathrm{e}^{* *} \mathbf{p}<\mathbf{0 , 2 0}$ (teste pelo qui-quadrado ou Fisher, quando o qui-quadrado não for adequado).

*Condições para entrada no modelo múltiplos (tabela 8), p<0,20 no teste do qui-quadrado ou Fisher.

Para estimação dos fatores associados ao comprometimento entraram, nos modelos múltiplos reduzido e completo, apenas as variáveis independentes com $p<0,20$ no teste do quiquadrado ou Fisher. 
$\mathrm{Na}$ análise múltipla reduzida, foram inseridas as variáveis sociodemográficas. No modelo múltiplo completo entre os colaboradores da empresa A, após a entrada da variável comunicação, observou-se a associação de alguns fatores como, por exemplo, anos de serviço, estado civil e boa comunicação (Tabela 7). Assim, esta tabela mostrou que a presença de uma boa comunicação, casado e ter entre 2 e 5 anos de serviço estão associados positivamente ao comprometimento.

No modelo múltiplo completo entre os colaboradores da empresa B apenas o fator boa comunicação permaneceu associado ao comprometimento (Tabela 8).

Nota-se nas estimativas de regressão logística uma maior magnitude do Odds ratio e menor precisão das estimativas observadas pelos intervalos de confiança, quando comparada às estimativas de Poisson. 
Tabela $\mathbf{n}^{0} 7$ - Modelos múltiplos logísticos e Poisson na estimativa de Odds ratios e Razão de prevalência de comprometimento ajustados pelas variáveis sociodemográficas e comunicação de funcionários de empresas de Telecomunicações. Empresa A, Cabo Verde, 2008.

\begin{tabular}{|c|c|c|c|c|c|c|c|c|c|c|c|c|}
\hline \multirow{3}{*}{ Variáveis } & \multicolumn{6}{|c|}{ Sociodemográficas (Modelo Reduzido)\$ } & \multicolumn{6}{|c|}{ Sociodemográficas ou Comunicação (Modelo completo)*** } \\
\hline & \multicolumn{3}{|c|}{ Logístico* } & \multicolumn{3}{|c|}{ Poisson robusto** } & \multicolumn{3}{|c|}{ Logístico* } & \multicolumn{3}{|c|}{ Poisson robusto $* *$} \\
\hline & OR & $\mathrm{IC}(95 \%)$ & $\mathrm{P}$ & $\mathrm{RP}$ & $\mathrm{IC}(95 \%)$ & $\mathrm{P}$ & OR & $\mathrm{IC}(95 \%)$ & $\mathrm{P}$ & $\mathrm{RP}$ & IC $(95 \%)$ & $\mathrm{P}$ \\
\hline \multicolumn{13}{|l|}{$\begin{array}{l}\text { Boa } \\
\text { comunicaç } \\
\text { ão }\end{array}$} \\
\hline Não & - & & & & & & 1 & & & 1 & & \\
\hline Sim & - & - & - & - & - & - & $\begin{array}{l}10,2 \\
4\end{array}$ & $(3,65 ; 28,74)$ & $<0,001$ & 2,48 & $(1,62 ; 3,79)$ & $<0,001$ \\
\hline \multicolumn{13}{|l|}{$\begin{array}{l}\text { Anos de } \\
\text { serviço } \\
\text { (anos) }\end{array}$} \\
\hline$<2$ & 1 & & & 1 & & & 1 & & & 1 & & \\
\hline $2|---| 5$ & 0,19 & $(0,02 ; 1,66)$ & 0,133 & $\$ \$$ & $\$ \$$ & $\mathbf{\$ \$}$ & 0,08 & $(0,00 ; 0,81)$ & 0,033 & 0,25 & $(0,04 ; 1,49)$ & 0,128 \\
\hline $6|---| 8$ & $\$ \$$ & $\mathbf{\$ \$}$ & $\$ \$$ & 1,51 & $(0,99 ; 2,31)$ & 0,055 & 2,46 & $(0,63 ; 9,64)$ & 0,197 & 1,35 & $(0,94 ; 1,94)$ & 0,103 \\
\hline $9|---| 11$ & $\$ \$$ & \$\$ & $\$ \$$ & $\$ \$$ & \$\$ & $\$ \$$ & $\$ \$$ & $\$ \$$ & $\$ \$$ & \$\$ & \$\$ & $\$ \$$ \\
\hline $\begin{array}{l}>12 \\
\text { Estado civil }\end{array}$ & \$\$ & \$\$ & $\$ \$$ & $\$ \$$ & \$\$ & $\mathbf{\$ \$}$ & $\mathbf{\$ \$}$ & $\$ \$$ & $\mathbf{\$ \$}$ & \$\$ & $\mathbf{\$ \$}$ & $\$ \$$ \\
\hline Solteiro(a) & 1 & & & & & & 1 & & & 1 & & \\
\hline Casado(a) & 2,13 & $(0,86 ; 5,25)$ & 0,100 & $\$ \$$ & $\$ \$$ & $\mathbf{\$ \$}$ & 2,45 & $(0,87 ; 6,69)$ & 0,089 & 1,31 & $(0,96 ; 1,79)$ & 0,089 \\
\hline Viúvo(a) & $\$ \$$ & $\mathbf{\$ \$}$ & $\$ \$$ & \$\$ & $\$ \$$ & $\mathbf{\$ \$}$ & $\mathbf{\$ \$}$ & $\$ \$$ & $\$ \$$ & $\mathbf{\$ \$}$ & $\$ \$$ & $\$ \$$ \\
\hline $\begin{array}{l}\text { Outras } \\
\text { situações }\end{array}$ & $\$ \$$ & $\$ \$$ & $\mathbf{\$ \$}$ & $\$ \$$ & $\$ \$$ & $\mathbf{\$ \$}$ & $\mathbf{\$ \$}$ & $\$ \$$ & $\mathbf{\$ \$}$ & \$\$ & $\$ \$$ & $\$ \$$ \\
\hline \multicolumn{13}{|l|}{$\begin{array}{l}\text { Faixa } \\
\text { etária } \\
(\text { anos) }\end{array}$} \\
\hline $18|---| 25$ & 1 & & & 1 & & & & $\mathbf{\$ \$}$ & $\mathbf{\$ \$}$ & \$\$ & $\mathbf{\$ \$}$ & $\mathbf{\$ \$}$ \\
\hline $26|--| 35$ & $\$ \$$ & \$\$ & $\$ \$$ & $\$ \$$ & $\$ \$$ & \$\$ & $\mathbf{\$ \$}$ & $\$ \$$ & $\$ \$$ & \$\$ & $\$ \$$ & $\$ \$$ \\
\hline $36|--| 45$ & $\$ \$$ & $\$ \$$ & $\$ \$$ & 1,48 & $(0,99 ; 2,22)$ & 0,058 & & $\$ \$$ & $\$ \$$ & \$\$ & $\$ \$$ & $\$ \$$ \\
\hline 46|---|60 & 2,96 & $(0,76 ; 11,61)$ & 0,119 & 1,98 & $(1,30 ; 3,02)$ & $<0,001$ & & $\$ \$$ & $\$ \$$ & \$\$ & $\$ \$$ & $\$ \$$ \\
\hline$>60$ & - & - & - & - & - & - & & $\$ \$$ & $\$ \$$ & \$\$ & $\$ \$$ & $\$ \$$ \\
\hline
\end{tabular}

Nota:* Estimativa de razão de chance pela estatística de regressão logística.

** Estimativa de razão de risco pela estatística de Poisson com variância robustas.

$\$ \mathrm{e} * * *$ estimados pelo modelo backward stepwise (saiu deste modelo as variáveis que tivessem $\mathbf{p}>\mathbf{0 , 2 0}$ ).

$\$ \$ \mathbf{p}>\mathbf{0 , 2 0}$ e saiu do modelo.

(b) O símbolo (-) significa o caso de não ocorrência de variáveis 
Tabela $\mathbf{n}^{0} 8$ - Modelos múltiplos logísticos e Poisson na estimativa de Odds ratios e Razão de prevalência de comprometimento ajustados pelas variáveis sociodemográficas e comunicação de funcionários de empresas de Telecomunicações. Empresa B, Brasil, 2008.

\begin{tabular}{|c|c|c|c|c|c|c|c|c|c|c|c|c|}
\hline \multirow{3}{*}{ Variáveis } & \multicolumn{6}{|c|}{ Sociodemográficas (Modelo Reduzido)\$ } & \multicolumn{6}{|c|}{ Sociodemográficas ou Comunicação (Modelo completo) $* * *$} \\
\hline & \multicolumn{2}{|c|}{ Logístico* } & \multirow{2}{*}{$\mathrm{P}$} & \multicolumn{2}{|c|}{ Poisson robusto** } & \multirow[b]{2}{*}{$\mathrm{P}$} & \multicolumn{2}{|c|}{ Logístico* } & \multirow{2}{*}{$\mathrm{P}$} & \multicolumn{3}{|c|}{ Poisson robusto** } \\
\hline & OR & IC $(95 \%)$ & & $\mathrm{RP}$ & IC $(95 \%)$ & & OR & IC $(95 \%)$ & & $\mathrm{RP}$ & IC $(95 \%)$ & $\mathrm{P}$ \\
\hline \multicolumn{13}{|l|}{$\begin{array}{l}\text { Boa } \\
\text { comunicação }\end{array}$} \\
\hline Não & - & & & - & & & 1 & & & 1 & & \\
\hline Sim & - & - & - & - & - & - & 8,10 & $(4,05 ; 16,19)$ & $<0,001$ & 3,39 & $(2,09 ; 5,50)$ & $<0,001$ \\
\hline \multicolumn{13}{|l|}{$\begin{array}{l}\text { Anos de } \\
\text { serviço (anos) }\end{array}$} \\
\hline$<2$ & 1 & & & 1 & & & 1 & & & 1 & & \\
\hline $2|---| 5$ & $\$ \$$ & $\$ \$$ & $\$ \$$ & $\$ \$$ & $\$ \$$ & $\$ \$$ & $\$ \$$ & $\$ \$$ & \$\$ & \$\$ & \$\$ & $\$ \$$ \\
\hline $6|--| 8$ & $\$ \$$ & $\$ \$$ & $\$ \$$ & $\$ \$$ & $\$ \$$ & $\$ \$$ & $\$ \$$ & $\$ \$$ & $\$ \$$ & \$\$ & $\$ \$$ & $\$ \$$ \\
\hline $9|---| 11$ & & & & $\$ \$$ & $\mathbf{S \$}$ & $\$ \$$ & & & & \$\$ & $\mathbf{S \$}$ & $\$ \$$ \\
\hline $\begin{array}{l}>12 \\
\text { Escolaridade }\end{array}$ & 2,09 & $(1,15 ; 3,78)$ & 0,015 & 1,47 & $(1,08 ; 1,99)$ & 0,013 & 1,57 & $(0,90 ; 3,39)$ & 0,097 & 1,26 & $(0,95 ; 1,68)$ & 0,104 \\
\hline $\begin{array}{l}\text { Médio } \\
\text { completo }\end{array}$ & $\$ \$$ & & & $\$ \$$ & & & $\$ \$$ & & & \$\$ & & \\
\hline $\begin{array}{l}\text { Superior } \\
\text { incompleto }\end{array}$ & $\$ \$$ & $\$ \$$ & $\$ \$$ & $\$ \$$ & $\$ \$$ & $\$ \$$ & $\$ \$$ & $\$ \$$ & $\$ \$$ & \$\$ & $\$ \$$ & $\$ \$$ \\
\hline $\begin{array}{l}\text { Superior } \\
\text { completo } \\
\text { Sexo }\end{array}$ & $\$ \$$ & $\$ \$$ & $\$ \$$ & $\$ \$$ & $\$ \$$ & $\$ \$$ & $\$ \$$ & $\$ \$$ & $\$ \$$ & $\$ \$$ & $\$ \$$ & $\$ \$$ \\
\hline Masculino & $\$ \$$ & $\$ \$$ & $\$ \$$ & $\$ \$$ & $\$ \$$ & $\$ \$$ & $\$ \$$ & $\$ \$$ & $\$ \$$ & $\$ \$$ & $\$ \$$ & $\$ \$$ \\
\hline $\begin{array}{l}\text { Feminino } \\
\text { Ter filho }\end{array}$ & \$\$ & $\$ \$$ & \$\$ & $\$ \$$ & $\$ \$$ & $\$ \$$ & & & & & & \\
\hline Sim & $\$ \$$ & $\mathbf{\$ \$}$ & $\mathbf{\$ \$}$ & $\$ \$$ & $\$ \$$ & $\mathbf{\$ \$}$ & & & & & & \\
\hline Não & $\$ \$$ & $\$ \$$ & $\$ \$$ & $\$ \$$ & $\$ \$$ & $\$ \$$ & & & & & & \\
\hline
\end{tabular}

Nota:* Estimativa de razão de chance pela estatística de regressão logística.

** Estimativa de razão de risco pela estatística de Poisson com variância robustas.

$\$ \mathrm{e} * * *$ estimados pelo modelo backward stepwise (saiu deste modelo as variáveis que tivessem p>0,20).

$\$ \$$ p $>0,20$ e saiu do modelo.

(b) O símbolo (-) significa o caso de não ocorrência de variáveis.

No próximo capítulo será discutida os resultados obtidos com a pesquisa realizada. 


\section{DISCUSSÃO DOS RESULTADOS}


Nas análises realizadas, descritiva e de associação, encontrou-se alguns resultados que doravante passa-se a discuti-los.

Este estudo é um dos poucos, em particular em Cabo Verde e Brasil, que estima fatores associados ao comprometimento de funcionários de empresas de telecomunicações, usando modelos múltiplos de regressão logística ou de Poisson.

Likert (1971) apesar de não ter como seu objetivo verificar a associação entre comunicação e comprometimento ressalta a existência de associação entre comunicação e produtividade. Na mesma linha, Dessler (1996) assegura que a comunicação é um dos fatores de comprometimento. Para este autor comprometimento é formado com base em confiança e esta requer um fluxo de comunicação de mão dupla. A comunicação aqui não pode ser considerada como sinônimo de recepção de informações, e sim como um processo que envolve transmissão, recepção, compreensão e aceitação ou rejeição (LIKERT, op. cit.; MISHRA, 2007).

Os resultados deste estudo apontaram que os participantes concordaram que o processo comunicativo dentro da empresa permite a comunicação em todas as direções, mediante vários meios, redes e fluxos, com concordância superiores a 85\% em todas as questões (tabelas 1 e 3 ). Estes resultados sugerem que as organizações se conectam por um fluxo de informações entre as pessoas que ocupam diferentes posições e representam distintos papéis, além de se relacionar com as suas subpartes que se conectam entre si por um fluxo de mensagens processadas em uma rede de relações interdependentes. A comunicação nas organizações pesquisadas se configura como um processo composto por métodos, estratégias, fluxos, redes e meios responsáveis por interligar as diferentes partes componentes da organização, de acordo com a concepção de Goldhaber (1991) e Tomlinson (2010).

Para que a comunicação interna tenda a ser mais eficaz deve haver uma ação estratégica e integrada de comunicação com o público interno e para isso deve dispor de canais e instrumentos diversos que permitem as pessoas das várias áreas da organização atuarem de forma sinérgica. Esta comunicação não deve se reduzir à transmissão de informações, sem a preocupação de gerar o feedback para as pessoas envolvidas no processo (REGO, 1986; HALL, 1994; KUNSCH, 2003; MARCHIORI, 2006; DEETZ apud MISHRA, 2007). Essa comunicação deve envolver ao mesmo tempo informação relevante para o trabalho, compreensão do que as pessoas querem, uso 
de canais adequados para a comunicação, feedback para que se exerça a criatividade assim como o reconhecimento do bom trabalho realizado (CODA, 1996). A maioria, com valores acima de $50 \%$, concordaram que recebem informações de outros setores. A existência de vários canais e meios de comunicação utilizados são percebidos pela maioria, maior que 75\%. Isso nos leva a crer que existe uma comunicação integrada, de acordo com o que dizem os autores pesquisados.

Em Relação à eficiência, eficácia e satisfação do processo de comunicação interna pouco mais de que $60 \%$ concordaram (tabelas 1 e 3). Percebe-se que ainda não existe uma integração completa dos setores, no que diz respeito à comunicação interna, o que, possivelmente, pode explicar as respostas em relação à eficiência, eficácia e satisfação.

O empregado precisa de informação para compartilhar do entendimento da visão da organização, construir sentimento de pertencimento, envolver-se e comprometer-se com as estratégias e objetivos da organização. Isso requer interação e diálogo. Os funcionários podem se comprometer com os objetivos organizacionais a partir do momento em que estiverem informados e integrados em um determinado contexto, o que exige contínua troca de informações e alteração de comportamentos da organização e dos próprios funcionários. A comunicação clara, verdadeira e direta que evidencia os objetivos e rumos organizacionais chama à participação, torna a organização conhecida e transparente, pode ser fator de sucesso das organizações, assim como comprometer os funcionários (MARCHIORI, 2006; GAVIN; MAYER apud MISHRA, 2007).

Portanto, é importante realçar que a comunicação não é sinônimo de recepção de informação. Comunicação é um processo que envolve diversos dimensionamentos tais como: transmissão da mensagem do remetente para o receptor; recepção e compreensão desta mensagem; e sua aceitação ou rejeição (LIKERT, 1971; MAYER apud MISHRA, 2007). Isso nos leva a entender que comunicação é diferente de receber informações, pois as informações precisam ser compreendidas e a partir daí gerar um feedback.

Compartilhando deste pensamento encontra-se Lite (1997) e Deetz apud Mishra (2007) que assim como Kunsch (1997) destacam a importância da comunicação interna dentro das organizações, mas defendem a idéia de que a comunicação dentro das organizações não é muito diferente do que o simples envio de informações. De acordo com os resultados deste estudo, o 
processo comunicativo nas organizações funciona, utilizando vários meios. Os fluxos de informação permitem a comunicação com chefias, pares e subordinados.

No que diz respeito à empresa $\mathrm{A}$, os resultados indicam que o Administrador Executivo entende que a comunicação não é eficaz. Essa opinião foi corroborada por $36 \%$ dos entrevistados na pesquisa quantitativa. Essas percepções encontram respaldo quando 34\% dos respondentes da pesquisa quantitativa declararam não receber informações de outros setores ou departamentos (tabela 1).

Portanto, pelo menos a partir da análise teórica que procedemos, considerara-se que, na empresa A, a comunicação se restringe a simples envio de informações, confirmando a posição de Lite (1997) e Deetz apud Mishra (2007) de que a comunicação dentro das organizações não é muito diferente do que o simples envio de informações e conseqüentemente, a comunicação é usada como sinônimo de informação. Provavelmente esse fato está ligado à exclusividade da empresa no mercado onde atua, à cultura da empresa e também da cultura do local.

Em relação à empresa $\mathrm{B}$, os dados da pesquisa revela-nos a preocupação com o feedback, pois segundo o diretor de comunicação e relações corporativas após todas as reuniões com executivos para apresentação de estratégias ou resultados, os executivos são orientados a repassar informações para suas equipes. Após essa etapa, são feitas pesquisas com os empregados para verificar se as informações foram repassadas e se foram compreendidas. Esta atitude confirma a conclusão de Thayer (1972) que assevera que quem está fazendo comunicação deve preocupar-se em considerar como o receptor está recebendo a informação como forma de obtenção de eficácia desejada da comunicação. Ainda referente à empresa $\mathrm{B}$, embora os respondentes percebessem que existe uma área de comunicação dentro da empresa, que ela é planejada e administrada estrategicamente assim como a importância da mesma para a organização, uma parte significativa dos respondentes, $48 \%$, afirma não receber informações de outros setores ou departamentos da empresa (tabela 3). Este resultado aponta que a comunicação integrada conforme postulam Kunsch (2003) e Oliveira e Paula (2006); Meade (2010) ainda não é realidade, pelo menos por essa porcentagem de respondentes.

Os dados deste estudo indicam que as duas empresas pesquisadas têm um planejamento estratégico da área de comunicação. Elevada porcentagem, por volta de $75 \%$, das pessoas 
participam de decisões que afetam os seus trabalhos, aspecto importante quando se almeja uma comunicação planejada. Existe a percepção da maioria, mais do que $75 \%$, de que existe o setor de comunicação dentro da organização e de que ela ocupa uma posição estratégica. A existência e reconhecimento desta área é um dos requisitos para que a comunicação seja planejada, pensada e administrada estrategicamente. Em torno de $85 \%$ dos respondentes concordaram que a área de comunicação dentro da empresa não funciona como bombeiro, ou seja, não atua de forma instrumental e pontual (tabelas 1 e 3), conforme ressalta (ABERJE, 2005). Os executivos principais responsáveis pela área de comunicação nas duas empresas têm formação na área de comunicação, entendem de planejamento estratégico. O que acabou se observando é que existem condições necessárias para que a comunicação seja planejada, de acordo com o que os pesquisadores da área propõem (KUNSCH, 2003; OLIVEIRA; PAULA, 2006; MARCHIORI, 2006). O planejamento de comunicação está ocorrendo nas organizações pesquisadas, ainda que em estágios diferentes para cada uma das organizações.

As pesquisas qualitativas, de uma forma geral, reforçam a percepção dos colaboradores abordados na pesquisa quantitativa. Contudo, alguns pontos merecem ser destacados. Em relação à empresa $\mathrm{B}$, embora o diretor da área de comunicação concordar que a comunicação ocupa um espaço estratégico, a maioria dos entrevistados na pesquisa quantitativa, 87\%, discorda quanto à ocupação da comunicação de um espaço estratégico dentro da organização. Em relação ao compartilhamento de informações entre setores/ departamentos da empresa, os colaboradores abordados na pesquisa quantitativa discordaram. 48\% dos respondentes declararam não receber informações de outros setores ou departamentos e 37\% declararam que o processo de comunicação não promove a integração entre os diferentes setores/ departamentos (tabela 3).

O fato de existir preocupação com a efetividade da comunicação interna na empresa B pode ser explicado pelo contexto em que ela atua, num ambiente de concorrência acirrada e para sobreviver ela já percebeu que deve investir na comunicação com os seus colaboradores além de investir na tecnologia, que, aliás, hoje é a condição sine qua non para qualquer empresa entrar no mercado.

Podemos notar que embora as empresas pesquisadas não atingirem uma comunicação eficiente, eficaz e satisfatório, de acordo com a concepção dos colaboradores, existe um esforço e uma preocupação para que tal aconteça. Os resultados apontam que a empresa B se preocupa com 
o processo de comunicação, ou seja, o receptor é valorizado neste processo (HALL, 1984; EISENBERG; GOODALL JR, 1997; DANIELS et al, 1997; GRUNIG, 2003). Por outro lado, a empresa A dá maior ênfase ao envio de informação. A comunicação ali é entendida numa perspectiva de passividade do receptor (KREPS, 1990; LITE, 1997; DEETZ apud MISHRA, 2007). No entanto, para a realidade e no contexto no qual a empresa A atua e nas condições em que atua, com exclusividade no mercado, reconhecer e dar importância à comunicação interna já é um avanço comparado às outras empresas do local.

Os dados desta pesquisa corroboram a tendência verificada na pesquisa Delphi de que a comunicação com os funcionários tem ganhado importância dentro das empresas e que aos gestores é oferecido a oportunidade de participarem na formulação do planejamento da empresa (FISCHER; ALBUQUERQUE, 2004; SHAW apud MISHRA, 2007).

De acordo com os resultados deste estudo verifica-se que a maior parte dos entrevistados concorda em quase todas as questões que são comprometidos afetivo, normativo e instrumentalmente. Em relação a estas dimensões, os respondentes concordaram em média 89\%, maior do que $70 \%$ e próximo de $75 \%$, respectivamente. Também houve uma percepção significativa, próximo de $64 \%$, de que a empresa dá benefícios que dificilmente encontra em outras organizações e de que deve participar e dedicar-se de corpo e alma à empresa, 70\% para a empresa B e 95\% para a empresa A (tabelas 2 e 4). Estes dados reforçam a existência de comprometimentos dos colaboradores com os objetivos organizacionais (MEYER; ALLEN, 1990).

Os resultados do presente estudo indicam que a maioria aceita os valores da empresa, valor maior do que 79\%; que existe um forte desejo de manter vínculo com a organização, acima de $90 \%$ e de que existe a intenção de se esforçar em prol da organização, 98\% (tabelas 2 e 4). Tais dados assinalam a existência de comprometimento, pois um empregado comprometido deve estar disposto em exercer um esforço considerável em benefício da organização; ter uma forte crença e aceitação dos objetivos e valores da organização; ter um forte desejo de se manter membro da organização (MOWDAY et al, 1982).

Em relação à empresa $\mathrm{B}$, embora os respondentes concordaram em média que $76 \%$ são comprometidos instrumentalmente, verifica-se que uma porcentagem significativa, 35\%, 
discordaram que a empresa lhes dá benefícios que dificilmente encontrariam em outra empresa. Em relação à dimensão normativa ainda que em média 74\% afirmam ser comprometidos, 30\% discordaram que um bom empregado deve dedicar-se de corpo e alma para a sua empresa (tabela 4). Já para a empresa A, no que tange à dimensão instrumental, em média, 79\% dos respondentes afirmaram ser comprometidos, porém 34\% dos respondentes discordaram que a empresa lhes dá benefícios que dificilmente encontrariam em outra empresa (tabela 2).

De acordo com a pesquisa qualitativa o comprometimento existente na empresa B é instrumental e afetiva, percepção essa que não é confirmada pelos colaboradores abordados na pesquisa quantitativa que concordaram em média, $89 \%$ que são comprometidos afetivamente, seguido do comprometimento instrumental com $79 \%$ de concordância em média (tabela 4). Quanto à empresa A o comprometimento existente é o instrumental, segundo os entrevistados, opinião diferente da dos colaboradores abordados na pesquisa quantitativa que concordaram em média $89 \%$ que são comprometidos afetivamente, seguido do comprometimento normativo com $84 \%$. O comprometimento instrumental veio por último com $79 \%$, em média, de concordância (tabela 2).

Conforme apresentamos anteriormente, a busca por uma melhor maneira de se relacionar com os colaboradores fez surgir novas estratégias organizacionais. Assim sendo, as estratégias de administração de pessoas podem ser divididas em dois tipos: estratégia de controle e de comprometimento. A estratégia de controle está baseada no desejo de estabelecer, exercer controle, alcançar eficiência na aplicação da força de trabalho. Já a estratégia de comprometimento se baseia na diminuição de níveis hierárquicos, na junção do planejamento e da execução no desenvolvimento das tarefas, mas principalmente que o comprometimento do empregado com os objetivos mais amplos levam a organização a um melhor desempenho (WALTON, 1997). Na estratégia de controle os empregados são vistos como números, custos e fator de produção, que, para desempenhar bem as suas funções, devem ser mandados e controlados, enquanto na estratégia de comprometimento as pessoas são consideradas parceiras no trabalho, nas quais a empresa deve investir para conseguir melhores resultados empresariais (ALBUQUERQUE, 2OO2).

De acordo com as entrevistas entende-se que a estratégia da empresa B tende a ser mais a de comprometimento, pois pelo menos em relação à política de $\mathrm{RH}$ a empresa dá possibilidade da 
pessoa fazer sua carreira dentro da empresa, contrata para uma carreira longa dentro da empresa, o foco é nos incentivos grupais vinculados a resultados empresariais, focada no desempenho, a promoção e progressão não estão atrelados ao tempo de serviço na empresa, a remuneração não é fixa. Estes resultados corroboram a tese de Walton (1997) de que a estratégia de comprometimento se baseia na diminuição de níveis hierárquicos, na junção do planejamento e da execução no desenvolvimento das tarefas, mas principalmente que o comprometimento do empregado com os objetivos mais amplos levam a organização a um melhor desempenho. Nesse tipo de estratégia as pessoas são consideradas parceiras no trabalho, nas quais a empresa deve investir para conseguir melhores resultados empresariais (ALBUQUERQUE, 2OO2).

Já em relação à empresa $\mathrm{A}$ os resultados apontam que existe um controle rígido com entrada e saída dos colaboradores; a progressão e promoção têm como base o tempo de permanência na empresa; a remuneração é fixa, embora tenha bônus que alguns colaboradores podem ganhar, é o departamento de RH responsável por toda a contratação do pessoal. Fica evidente que a estratégia adotada tende a ser mais a de controle conforme ressalta Walton (op. cit) ao afirmar que esse tipo de estratégia está baseada no desejo de estabelecer e exercer controle, alcançar eficiência na aplicação da força de trabalho. Nesse tipo de estratégia os empregados são vistos como números, custos e fator de produção, que, para desempenhar bem as suas funções, devem ser mandados e controlados (ALBUQUERQUE, 2OO2).

No entanto, dificilmente encontramos, hoje, uma empresa que tem uma única estratégia. O que tem-se observado é uma mescla das estratégias, com ênfase numa ou outra. O que acabou se observando, na realidade foi uma concomitância, nas duas empresas pesquisadas, dos dois tipos de estratégias, embora com ênfase numa ou noutra. Verificamos que a empresa A enfatiza a estratégia de controle, porém notamos tendências modernizantes de práticas de gestão de recursos humanos, tais como os bônus e a possibilidade do colaborador fazer uma carreira dentro da empresa, o treinamento é privilegiado de acordo com a avaliação e necessidade da empresa e do colaborador. Isso encontra respaldo na visão de Albuquerque (2OO2) que assevera que hoje é comum encontrarmos uma empresa com os dois tipos de estratégias, embora enfatizando uma ou outra.

Provavelmente essa diferença de estratégia está relacionada com a lógica de operar em mercados com diferentes estruturas, oligopólio (empresa B) e monopólio (empresa A). Um ponto 
que pode ocasionar dificuldades para a empresa A ter uma comunicação de fato, ou seja, preocupar com o feedback pode ser o fato da ênfase na estratégia de controle.

Formação de novas competências, orientação e consultoria ao corpo gerencial, preparação e acompanhamento das mudanças organizacionais, promoção do trabalho em equipe e a implementação de relações sociais são responsabilidades que exigem dos gestores de recursos humanos e gestores de linha uma postura de envolvimento e comprometimento (DESSLER, 1996). Como fator decisivo nesse processo de envolvimento está a comunicação em todos os níveis. Os resultados do presente estudo, principalmente o da pesquisa qualitativa, evidencia essa preocupação e postura dos gestores que afirmam ser comprometidos com os objetivos organizacionais, tentam mobilizar a sua equipe para a mesma direção além de abrir espaço para uma comunicação efetiva.

Nas análises uni-variadas, verificou-se que comunicação, anos de serviço, estado civil, faixa etária e escolaridade estão associadas ao comprometimento, em nível de significância de $5 \%$ ou 10\%, conforme revelam as tabelas 5 e 6 . Este resultado ratifica as conclusões de Eisenberg e Goodall Jr. (1997) de que o impacto da participação em redes de comunicação sobre atitudes e comportamentos dos trabalhadores podem ocorrer apenas em empregados com determinadas características.

Os resultados do presente estudo mostram que existe uma alta associação e positiva entre comprometimento e comunicação interna (tabelas 5, 6, 7 e 8). Pesquisas semelhantes apontam para a mesma direção, que existe uma forte dependência e associação entre a comunicação e comprometimento, (LIKERT, 1971; EISENBERG et al, 1983; WATKINS, 1992; DESSLER, 1996; MEYER et al, 1998; CHANG JUNIOR, 2001; POSTMES et al, 2001; TAVARES, 2005; CARRIÈRE; BOURQUE, 2008; TAVARES; LIMNOGI-FRANÇA, 2005, 2009, 2010).

Outros estudos desenvolvidos que não tiveram o objetivo de verificar essa relação realçam a importância da comunicação para o desenvolvimento do comprometimento (THAYER, 1972; ALBUQUERQUE, 1999; VARONA, 2002; MARCHORI, 2006; SCHEIBLE; BASTOS, 2006; MISHRA, 2007; ALEXANDER et al, 2009; MEAD, 2010; SAMGNANAKKAN, 2010; TOMLINSON, 2010). Por isso a necessidade de desenvolver estudos que propõem um modelo 
no qual a comunicação seria uma das variáveis que possibilita explicar ou ajudar a explicar o desenvolvimento do comprometimento organizacional.

É possível que as empresas pesquisadas, neste estudo, já perceberam que participação efetiva exige informações e que o empregado necessita de informação para que possa envolver-se e engajar-se. É de se realçar que a informação a que nos referimos deve ser aquela que provoca o diálogo, o fazer parte, a interação social. Portanto, a participação do empregado, sua melhor produtividade seu comprometimento está cada vez mais relacionado com a gama de informações que recebe da organização.

Os resultados deste estudo apontam a preocupação das empresas em fazer com que os colaboradores conheçam a empresa como um todo assim como a preocupação em dar possibilidade dos mesmos comunicarem com todos e se comunicarem entre eles, ratificando a visão de Marchiori (2006) de que quanto maior for o envolvimento do funcionário maior poderá ser o seu comprometimento e para que isso ocorra faz-se necessário criar um ambiente interno no qual informação, conhecimento e competência fluam livremente para que existam comprometimento pessoal e autodesenvolvimento, aspectos que contribuem para um crescimento organizacional.

Os resultados desta pesquisa indicam que as diferenças entre tipo de empresas foram significativas na explicação do comprometimento em nível de $10 \%(\mathrm{p}=0,098)$. Assim fez-se o estudo separado por tipo de empresa (tabelas 5 a 8), porque as diferentes estruturas de mercado, monopólio e oligopólio, interferem nos fatores associados ao comprometimento organizacional. Para a empresa A (monopólio) além de uma boa comunicação, alguns fatores sociodemográficos, quais sejam, ser casado e ter entre 2 e 5 anos de serviço, estavam associados positivamente ao comprometimento, em nível de significância de 5\% ou 10\% (tabelas 5 e 7).

Resumindo, as análises realizadas permitiram verificar que comunicação e algumas variáveis sociodemográficas são fatores associados ao comprometimento. Cabe realçar também que o tipo de empresa explica o comprometimento organizacional.

No próximo capítulo segue as considerações finais, ressaltando as limitações, as contribuições assim como as recomendações para o desenvolvimento de estudos futuros. 


\section{CONCLUSÕES}


Para efetivar uma estratégia de comprometimento negociado, ou seja, um compromisso via comunicação, com certo grau de envolvimento e participação de todas as pessoas dentro da organização, faz-se mister uma comunicação interna estratégica e planejada, dispondo de canais e instrumentos diversos que permitem a atuação sinérgica de todas as áreas da organização.

Ao verificar os fatores associados ao comprometimento de funcionários de empresas de telecomunicações, o teste qui-quadrado de Pearson ou Fisher e as estimativas de regressão logística e de Poisson múltipla apontam que existe uma alta associação e positiva entre comprometimento e comunicação interna, independentemente do tipo de empresa e de ajuste ou não às variáveis sociodemográficas. Estes resultados sugerem que a comunicação interna é uma das variáveis mais importantes na explicação do comprometimento, portanto as empresas que almejam colaboradores comprometidos têm que dedicar uma devida atenção a ela.

Os resultados desde estudo ainda indicam que as diferenças entre tipo de empresas foram significativas na explicação do comprometimento. Assim fez-se o estudo separado por tipo de empresa. Contudo, estes resultados sugerem que existem algumas similaridades em relação às políticas e práticas de gestão de pessoas nas empresas estudadas, o que sugere que tais práticas e políticas estão comuns globalmente.

Para a empresa A além do fator boa comunicação e alguns fatores sociodemográficos, tais como: casado e ter entre 2 e 5 anos de serviço estão associados positivamente ao comprometimento, em modelo múltiplo ou modelo univariado.

Essa associação pode ser explicada pela questão cultural, pois em Cabo Verde, geralmente quando a pessoa tem mais do que dois anos de serviço é efetivada pela instituição o que lhe garante estabilidade e um vínculo por tempo indeterminado. Este fato parece ter explicado positivamente a freqüência de comprometimento entre funcionários com 2 a 5 anos de serviço.

De uma forma geral, na cultura cabo-verdiana quando a pessoa é casada, ela almeja mais ter uma estabilidade no emprego do que quando não é casada. Isso pode ter explicado positivamente a freqüência de comprometimento entre funcionários que declararam ser casados, quando comparado aos outros estados conjugais. 
A análise descritiva indica que as empresas possuem meios e canais que permitem que as pessoas dentro da organização se comuniquem nas mais diversas direções, formal e informalmente. Os resultados ainda apontam que os respondentes estão comprometidos afetiva, instrumental e normativamente.

As pesquisas qualitativas acabaram reforçando a percepção dos colaboradores abordados na pesquisa quantitativa em relação aos constructos comunicação interna e comprometimento organizacional. Contudo, a comunicação que os respondentes afirmam existir parece não ser realmente comunicação e sim informação, pois a preocupação maior das empresas, principalmente a A, é fazer as pessoas saberem do que se passa dentro da organização.

Vale ressaltar que para uma empresa ter uma comunicação interna eficaz, não basta dispor-se de meios e canais que se limitam a transmitir informações de forma unilateral, sem possibilitar aos colaboradores participação nas decisões que tem a ver com o seu trabalho e conhecimento do negócio da empresa como um todo, perpassando objetivos, visão, missão entre outras. A comunicação contribui para eficácia organizacional e é fundamental para que a organização alcance seus objetivos; os colaboradores assim como outros stakeholders têm seus próprios objetivos e expectativas e reconhecer tais expectativas requer um trabalho planejado de comunicação interna que respeite características do público interno e da própria organização.

Desta maneira, para as organizações que dependem das pessoas para garantir a sua vantagem competitiva, pautar-se por um planejamento da comunicação organizacional e conseqüentemente uma comunicação interna integrada, ou seja, uma comunicação planejada e estratégica torna-se uma prerrogativa para fazer com que as pessoas se comprometam com a organização e, com isso, se envolvam com os negócios da organização como um todo.

Embora em Cabo Verde estudos sobre comunicação interna e comprometimento estão se iniciando, o resultado do presente estudo reitera os resultados de estudos semelhantes desenvolvidos em outros países, sugerindo o surgimento de práticas globalizantes no que se refere às políticas de gestão de pessoas. 


\subsection{Limitações do estudo}

É importante registrar que esta pesquisa, como todos os estudos de caso, apresenta uma limitação: mostra o retrato pontual de apenas empresas estudadas e que têm características bem peculiares. As conclusões extraídas das análises deste estudo não devem ser generalizadas para a população das estudadas. Os estudos dessa natureza são suscetíveis a vieses de declaração pelos funcionários.

Os estudos transversais são de baixo custo, rápidos e permitem estimar prevalência. Contudo, não estabelecem a seqüência dos eventos em análise, isto é, não levam à compreensão do tema ao longo do tempo, o que pode ser empecilho no estabelecimento de relações de causa e efeito.

\subsection{Contribuições do estudo}

O presente estudo insere-se numa vertente que procura ampliar o conhecimento sobre as possíveis influências da comunicação e das variáveis sociodemográficas no comprometimento.

Este é o primeiro estudo realizado em Cabo Verde que verifica os fatores associados ao comprometimento e um dos poucos na literatura que estima fatores associados ao comprometimento utilizando modelos múltiplos de logístico e Poisson robusto (Backward stepwise Wald), com o intuito de verificar a melhor opção por se tratar de um estudo transversal. Observou-se que nas estimativas de regressão logística houve maior magnitude do Odds ratio e menor precisão das estimativas observadas pelos intervalos de confiança quando comparada às estimativas de Poisson.

Considera-se que este estudo contribui para a discussão da possibilidade concreta de implantação de políticas de gestão de pessoas nas organizações, nomeadamente comunicação interna e estratégia de comprometimento, independentemente da estrutura do mercado em que elas atuam, uma vez que tais políticas trazem benefícios às organizações e às pessoas. 


\subsection{Recomendações para estudos futuros}

Os estudos transversais têm sido utilizados para o reconhecimento de possíveis causas, a serem incluídas em estudos longitudinais que são mais adequados para descreverem os fatores de risco de um determinado evento em estudo. O presente estudo abre campo para outras pesquisas probabilísticas, que permitem inferir dados da amostra para a população. Portanto, sugere-se a realização de estudos longitudinais que apliquem a mesma metodologia do presente estudo em empregados de empresas de telecomunicações, em diferentes estruturas de mercado, o que poderá reforçar ou complementar os dados sobre os fatores associados ao comprometimento em empresas de telecomunicações.

\subsection{Sugestões para as empresas pesquisadas}

Os resultados deste estudo possibilitaram identificar fatores associados ao comprometimento de colaboradores das empresas estudas. Sugere-se, a partir destes resultados:

* Aprimorar a comunicação interna para que ela seja eficaz: possibilitando uma comunicação dialógica entre todos da empresa, por meio de vários meios, fluxos e redes;

* Promover o compartilhamento de informações entre as áreas/ departamentos: que todos compartilhem as mesmas informações, conheçam o negócio da empresa como um todo e saibam, unanimemente, os objetivos organizacionais;

* Adotar uma estratégia de comprometimento, oferecendo estabilidade, perspectiva de carreira, reconhecimento: essa estratégia tende a ser melhor para a empresa e para os colaboradores;

Alinhar os processos de gestão de pessoas (contratação, promoção, remuneração, avaliação, treinamento) para uma efetiva prática de estratégia de comprometimento. 
Portanto, para que as empresas pesquisadas mantenham os colaboradores comprometidos com os seus objetivos organizacionais, faz-se necessário o alinhamento dos esforços no alinhamento de práticas de gestão de pessoas que atendam as expectativas, de um lado, da organização e, do outro lado, dos colaboradores. 


\section{REFERÊNCIAS}


AAKER, D. et al. Marketing Research. 5 ed. New York: John Wiley \& Sons, INC, 1995.

ABTD - Associação Brasileira de Normas Técnicas. NBR 6028: Informações e documentação: resumo. Rio de Janeiro, 2003.

ABERJE. Comunicação interna: a força das empresas. NASSAR, Paulo (Org.). v. 2. São Paulo: ABERJE, 2005.

. Pesquisa: evolução sob moldes tradicionais - Comunicação Empresarial. Revista About. São Paulo, Versart. No 646, p. 10-12, set. 2001.

ALBUQUERQUE, L. G. Estratégias de Recursos Humanos e Competitividade. In: VIEIRA, M. M. F.; OLIVEIRA, L. M. B. (Org.). (1999). Administração Contemporânea: perspectivas estratégicas. São Paulo: Atlas, 1999.

. Competitividade e recursos humanos. Revista de Administração da USP, vol. 27, n. 4, out-dez, 1992, p. 16-29, São Paulo.

. O papel estratégico de recursos humanos. São Paulo, 1987. 238 p. Tese (Livre Docência em Administração). Faculdade de Economia, Administração e Contabilidade, Universidade de São Paulo.

- A gestão estratégica de pessoas. In: FLEURY, M. T. L. (Org.). As pessoas na organização. São Paulo: Editora Gente, 2002a.

ALEXANDER, $\mathrm{J}$ et al. On the quest for world-class internal communication: some findings from recent research into wath best-practice internal commmunication looks like. SCM. Vol. 13, issue 4, june/ july 2009

ARGYRIS, C. Good communication that blocks learning. In: HBR, Managerial excelence: McKinsey award winners from the HBR 1980-1994. Boston: USA, p. 303-318.

ARMSTRONG, G.; KOTLER, P. Introdução ao Marketing. 4. ed. Rio de Janeiro: LTC, 2000.

BANDEIRA, M. L et al. As dimensões múltiplas do comprometimento organizacional: um estudo na ECT/MG. Revista de Administração Contemporânea. São Paulo, v.4, n.2, p.133157, mai/ago. 1999.

BASTOS, A. V. B.; BORGES-ANDRADE, J. E. Comprometimento com o trabalho: padrões em diferentes contextos organizacionais. Revista de Administração de Empresas. São Paulo, v.42, n.2, p. 31-41, abr/jun. 2000.

Comprometimento no trabalho: a estrutura dos vínculos do trabalhador com a organização, a carreira e o sindicato. Tese de doutorado do programa de Pós-graduação do Instituto de Psicologia da Universidade de Brasília. 1994. 
. Comprometimento organizacional: um balanço de resultados e desafios que cercam essa tradição de pesquisa. Revista de Administração de Empresas. São Paulo, v.33, n.3, , p. 52-64, abr/jun. 1993.

. Comprometimento no trabalho: os caminhos da pesquisa e os seus desafios teóricometodológicos. In: TAMAYO, A et al. (Org.). Trabalho, organizações e cultura. São Paulo: ANPEPP, 1997.

BATEMAN, D. N. The employee's right to know the issues and the corporation's responsibility to communicate. The Journal of Business Communication, v. 14, n. 2, 2003.

BATESON, J. E. G.; HOFFMAN, K. D. Marketing de serviços. Tradução Lucia Simonini. 4. ed. Porto Alegre: Bookman, 2001.

BECKER, B. E et al. Gestão estratégica de pessoas com scorecard: Interligando pessoas, estratégia e performance. Rio de Janeiro: Campus, 2001.

BECKER, H. S. Notes on the concept of commitment. The American Journal of Sociology, 66, 32-40, 1960.

BECKER, T. E. Foci and bases of commitment: are they distinctions worth making? Academy of Management Journal. Vol. 35 Issue 1, 232-244, Mar, 1992.

BORGES-ANDRADE, J. E et al. Comprometimento organizacional em instituição de pesquisa: diferenças entre meio e fimm. Revista de Administração. São Paulo: FEA/USP, v.25, n.4, 29-43, outubro/dezembro, 1990.

BOWDITCH, J.; BUONO, A. F. Elementos de comportamento organizacional. São Paulo: Escrituras Editora, 2001.

BRANDÃO, M. G. A.; BASTOS, A. V. B. Comprometimento organizacional em uma instituição universitária. Revista de Administração, São Paulo, v.28, n.3, p. 50-61, jul./set. 1999.

BRUM, A. M. Um olhar sobre o marketing interno. Porto Alegre: L\&PM, 2000.

BUENO, W. C. Comunicação organizacional: teoria e pesquisa. Barueri, São Paulo: Manole, 2003. 2005.

. Comunicação empresarial no Brasil: uma leitura crítica. São Paulo: All Print Editora,

CAMPOMAR, M. C. Do uso de estudo de caso em pesquisas para dissertações e teses em Administração. Revista de Administração. São Paulo: FEA/USP, v. 26, n. 3, 95-97, julho/setembro, 1991.

CARLSON, J. Moment of truth. New York: Balligen, 1987. 
CARRIÈRE, J.; BOURQUE, C. The effects of organizacional communication on jib satisfaction and organizational commitment in a land ambulance service and the mediating role of communication satisfaction. Career Development Internacional, vol. 14, n. 1, 2009, p. 29-49

CASTELLS, M. La era de la información: economia, sociedad y cultura. La Sociedad. Madrid: Alianza Editorial, 1998.

. A sociedade em rede: a era da informação: economia, sociedade e cultura. São Paulo: Paz e Terra, 1999.

CASTRO, C. M. A prática da pesquisa. São Paulo: McGraw-Hill, 1977.

CHANG-JUNIOR, J. Gestão de pessoas pelo desenvolvimento do comprometimento organizacional: uma abordagem holística e simultânea dos determinantes envolvidos no processo. São Paulo, 2001. 192 p. Tese (Doutorado em Administração). Faculdade de Economia, Administração e Contabilidade, Universidade São Paulo.

; ALBUQUERQUE, L. G. de. Inovações tecnológicas e o comprometimento organizacional. In: Conocimiento, innovación y competitividad: los desafios de la globalización. Seminario Latino-Iberoamericano de Gestión Tecnológica - ALTEC, 10. 2003. Ciudad de México.

; __ Estratégia de comprometimento em gestão de pessoas: In: SLADE 2002, Montevideo. Anais do SLADE - CD-ROM, 2002.

CHANLAT, J. F. Por uma antropologia da condição humana nas organizações. In: CHANLAT, J. F. (Coordenador). O indivíduo na organização: dimensões esquecidas. 3.ed. São Paulo: Atlas, 1996, v.1.

. Administração: teoria, processo e prática. São Paulo: Makrom Books, 1997.

. Gerenciando pessoas: o passo decisivo para a administração participativa. São Paulo: Makrom Books, 1994.

CODA, R. Pesquisa de clima organizacional e gestão estratégica de RH. In: BERGAMINI, C.; CODA, R. (Org.). Psicodinâmica da vida organizacional: motivação e liderança. 2. ed. São Paulo: Atlas, 1997.

COLWELL, J. Qualitative Market Research: A conceptual analysis \& review of practitioner criteria, Journal of the Market Research Society. London, v. 32, n.1, p 13-36, Jan. 1990.

CORRADO, F. A força da comunicação: quem não se comunica.... São Paulo: Makron Books, 1994.

COSTA, J. Comunición corporativa e revolución de los serviços. Madrid: Ediciones Ciencias Sociales, 1995. 
COSTA, J.A; MELO, A. S. Dicionário da Língua Portuguesa: dicionários editora. Porto: Porto Editora, 1999.

DANIELS T. D et al. Perspectives on organizational communication. Fourth edition Dubuque, USA: Brown \& Benchmark Publishers, 1997.

DATABERJE. Pesquisa comunicação interna: disponível em: http://www.aberje.com.br/novo/pesquisa_aberje. Acesso em 02 de novembro de 2007.

DERTOUZOUS, M. L et al. Made in America: regaining the productive edge. Ninth printing. Cambridge, Mass: The MIT Press, 1991.

DESSLER, G. Conquistando comprometimento - como construir e manter uma força de trabalho competitiva. São Paulo: Mackron Books, 1996.

DUPONT, W. D. Statistical Modeling for Biomedical Researchers: A Simple Introduction to the Analysis of Complex Data. $1^{\text {st }}$. Edition, New York, USA: Cambridge University Press, 2002

DUTRA, J. S. A gestão de pessoas na empresa moderna: abordagem conceitual e instrumental à luz dos conceitos de competência, complexidade e espaço ocupacional. São Paulo, 2004. 280 p. Tese (Livre Docência em Administração). Faculdade de Economia, Administração e Contabilidade, Universidade de São Paulo.

EISENBERG, E. M.; GOODALL-Jr. H. L. Organizational communications: balancing, creativity and constraint. 2nd ed. New York, USA: St Martin's Press, 1997.

EISENBERG, E. M et al. Involvement in Communication Networks as a Predictor of Organizational Commitment. Human Communication Research, v.10, n.2, 179-201, 1983.

ETZIONI, A. Organizações modernas. São Paulo: Pioneira, 1976.

FARIA, A. N.; SUASSUNA, N. R. A comunicação na Administração. Rio de Janeiro: Editoras Sesat e LTC, 1982.

FISCHMANN, A. A., ALMEIDA, M. I. R. Planejamento estratégico na prática. São Paulo : Atlas, 1991.

FISCHER, A. L.; ALBUQUERQUE, L. G. DELPHI - RH 2010: Tendências em gestão de pessoas nas empresas Brasileiras. 2. ed. São Paulo: Progep-USP, 2004.

FISCHER, R. M.; FLEURY, M. T. L. Processo e relações do trabalho no Brasil. São Paulo: Atlas, 1992.

FLEURY, M. T. L. O desvendar a cultura de uma organização: uma discussão metodológica. In: FISCHER, R. M.; FLEURY, M. T. L Cultura e poder nas organizações. 2.ed. São Paulo: Atlas, 1996. 
FLEURY, A. C. C. Estratégias, organização e gestão de empresas em mercados globalizados: a experiência recente do Brasil. Gestão e Produção. São Paulo: Poli-USP, v. 4, n. 3, 264-277, dez, 1997.

FITZ-ENZ, J. The 8 practices of excepcional companies: how great organizations make the most of their human assets. New York: Amocon: 1997.

FPNQ - Fundação Para o Prêmio Nacional da Qualidade. Critérios de Excelência. 2001.

FREITAS, M. E. Cultura organizacional: identidade, sedução e carisma. Rio de Janeiro: FGV, 1999.

. Cultura organizacional: formação, tipologia e impacto. São Paulo: McGraw-Hill, 1991.

FREITAS, S. G. Cultura organizacional e comunicação. In: KUNSCH, M. M. K. (Org.). Obtendo resultados com relações públicas. 2. ed. São Paulo: Pioneira Thomson Learning, 2006.

GIL, A. C. Como elaborar projetos de pesquisa. 4. ed. São Paulo: Atlas, 2002.

Métodos e Técnicas de Pesquisa Social. 3. ed. São Paulo: Atlas, 1991.

GODOY, A. S. Pesquisa Qualitativa: Tipos Fundamentais. Revista de Administração de Organizações, São Paulo. v. 35. n. 2, mai/jun. 1995.

GOLDHABER, G. M. Comunición organizacional. Trad. De José Manuel Balagner. México: Editorial Diana, 1991.

GOULART, T. Comunicação empresarial: uma nova realidade em Minas. Disponível em: http://www.aberje.com.br/clipping/clipping.htm. Acesso em 12 de dezembro de 2007.

GOULDNER, H. P. Dimensions of organizational commitment. Administrative Science Quaterly. 4, 468-490, 1960.

GRUNIG, J. E. A função das Relações Públicas na administração e sua contribuição para a efetividade organizacional e societal. Comunicação \& Sociedade, São Bernardo do Campo: Umesp, ano 24, n. 39, 2003.

HAIR J. F et al. Fundamentos de métodos de pesquisa em administração. Trad. Lene Belon Ribeiro. Porto Alegre: Bookman, 2005a.

et al. Análise multivariada de dados. Tradução de Adonai Schhhlup Sant'Anna e Anselmo Chaves Neto. Porto Alegre: Bookman, 2005b.

HALL, R. H. Organizações: estrutura e processos. Tradução de Wilma Ribeiro. 3. ed. Rio de Janeiro: Prentice-Hall, 1984. 
HARMAN, W.; HORMANN, J. O trabalho criativo: papel construtivo dos negócios numa sociedade em transformação. Tradução de Maria Silvia Mourão Netto. São Paulo: Editora Cultrix, 1997.

HERMOSA, J. D. C. La empresa ante de los medios de comunición. Bilbao: Dusto Sa, 1990.

HREBINIAK, L. G.; ALLUTO, J. A. Personal and role-related factores in the development of organizational commitment. Adminstrative Science Quaterly. 17, 555-573, 1972.

HUSELEID, M. A. The impact of human resource management practices on turnover, productivity and corporate financial performance. Academy of Management Journal. 38 (3), 635-672, 1995.

Instituto Nacional de Estatística de Cabo Verde. Censo demográfico 2000. Praia: Instituto Nacional de Estatística de Cabo Verde; 2002.

. Inquérito demográfico e de saúde reprodutiva 1998. Praia; 2000.

JABLIN, F. M.; PUTNAM, L. L. (Ed). The new handbook of organization: advances in theory, research and methods. London: Sage Publications, 2001.

KELMAN, H. C. Compliance, identification and internalization: three process of attitude change. Journal of Conflict Resolution. V. 2, p. 51-60, 1958.

KERLINGER, F. N. Metodologia da pesquisa em ciências sociais. São Paulo: EPU, 1980.

KINNEAR, T. C.; TAYLOR, J. Marketing Research: an applied approach. 5th ed. New York: Mc Graw-Hill, 1996.

KOTLER, P. Administração de Marketing: a edição do milênio. Trad. De Bázan Tecnologia e Lingüística. 10. ed. São Paulo: Prentice Hall, 2000.

KREEPS, G. L. La comunicación en las organizaciones. Buenos Aires: Addison Wesley Iberoamericano, 1995.

- Organizational communication: theory and practice. 2nd ed. New York, USA: Longman, 1990.

KUNSCH, M. M. K. Planejamento de relações públicas na comunicação integrada. 4. ed. Revista, ampliada e atualizada. São Paulo: Summus, 2003.

. Relações Públicas e modernidade: novos paradigmas na comunicação organizacional. São Paulo: Summus, 1997.

. Planejamento estratégico e excelência da comunicação. In: KUNSCH, M. M. K. (Org.). Obtendo resultados com relações públicas. São Paulo: Pioneira Thomson Learning, 2006 a. 
- Comunicação organizacional: conceitos e dimensões dos estudos e das práticas. In: MARCHORI, M. (Org.). Faces da cultura e da comunicação organizacional. São Caetano do Sul, SP; Difusão Editora, 2006b.

LAKATOS, E. M.; MARKONI, M. A. Fundamentos de Metodologia Científica. 3. ed. São Paulo: Atlas, 2002.

; ___ A técnica de pesquisa: planejamento e execução de pesquisas em amostragens e técnicas de pesquisa, elaboração, análise e interpretação de dados. São Paulo: Atlas, 1990.

LASWELL, H. The structure e function of communication in society. In: BRYSON, L. (ed.). The communication of ideas. New York: IRSS, 1998.

LAZZARINI, S. G. Estudo de caso: Aplicabilidade e limitações do método para fins de pesquisa. Economia \& Organização, São Paulo: v.2, n.4, 17-26, out/dez, 1995.

LIKERT, R. A Technique for the Measurement of Attitudes. Archives of Psychology, Vol. 22, N. 140, 1932, p. 1-55

LIKERT, R. Novos padrões de Administração. Tradução de Albertino Pinheiro Junior e Ernesto D’Orsi. São Paulo: Atlas, 1971.

LIMONGI-FRANÇA, A. C. Interfaces da Qualidade de Vida no Trabalho na Administração de Organizações: fatores críticos da gestão organizacional para uma nova competência. São Paulo, 2001. 247 p. Tese (Livre docência). Faculdade de Economia, Administração e Contabilidade, Universidade de São Paulo.

. Práticas de Recursos Humanos PRH: Conceitos Ferramentas e Procedimentos. São Paulo: Atlas, 2007.

LITE, M. del P. Cultura empresarial y comunicación interna: su influencia en la gestión estratégica. Madrid: Fragua Editorial, 1997.

LITTERER, J. Análise das organizações. São Paulo: Atlas, 1977.

LOSICER, E. A procura da subjetividade: a organização pede análise. In: Recursos Humanos e Subjetividade. Petrópolis, RJ: Vozes, 1995.

LUPETTI, M. Planejamento de comunicação. São Paulo: Futura, 2000.

MAgAlHÃes, H. A. Comunicação Empresarial nos dias de hoje. Disponível em: http://www.aberje.com.br/clipping/clipping.htm. Acesso em 10 de dezembro de 2008.

MAlHOtRA, N. K. Pesquisa de Marketing: uma orientação aplicada. 4. ed. Porto Alegre: Bookman, 2006. 
MARCHORI, M. Comunicação interna: a organização como um sistema de significados compartilhados. In: MARCHORI, M. (Org.) Faces da cultura e da comunicação organizacional. São Caetano do Sul, SP; Difusão Editora, 2006.

MARQUES, G. M. Comprometimento organizacional: o estado da arte da pesquisa no Brasil. Revista de Administração Contemporânea, São Paulo, v.7, n.4, 187-209, out/dez.2003.

MARTINS, G. A. Manual para formatação e edição de dissertações e teses. MARTINS, Gilberto A. (Org.). PAULI, Sergi; KANAZAWA, Érika Y. (Colaboradores). São Paulo, FEA-USP, 2004.

MATHIEU, J. E.; ZAJAC, D. M. A review and meta-analisys of the antecedents, correlates and consequences of organizational commitment. Psychology Bulletin, 108, 171-194, 1990.

MATTAR, F. N. Pesquisa de marketing. São Paulo: Atlas. 1996

MEADE, J. A. Strategic planning internal communication. CPA Practice Management Forum. January, 2010

MEDEIROS, C. A. F et al. Comprometimento organizacional: o estado da arte da pesquisa no Brasil. Revista de Administração Contemporânea, v.7, n.4, out./dez. 2003, p. 187-209.

; ENDERS, W. T. Validação do modelo de conceitualização de três componentes do comprometimento organizacional (Meyer e Allen, 1991). RAC, v. 2. n. 3, Set./Dez. 1998, p. 6787.

MEDEIROS, C. A. F. Comprometimento organizacional: um estudo de suas relações com características organizacionais e desempenho nas empresas hoteleiras. São Paulo, 2003. 181 p. Tese (Doutorado em Administração). Faculdade de Economia, Administração e Contabilidade, Universidade de São Paulo.

MEYER, J. P et al. Affetive and continuance commitment to the organizations: evaluation of measures and analysis of concurrent and time-lagged relations. Journal of applied psychology. N.75, 710-720, 1990.

et al. Commitment to organizations and ocupations: extension and test of a threecomponent conceptialization. Journal of Aplied Psychology. vol. 78, Issue 4, 538-551, 1993.

; ALLEN, N. J. A three component conceptualization of organizational commitment. Human Resource Management Review. Vol. 1, Issue 1, 61-89, spring, 1991.

; C_ Commitment in the workplace: theory, research and application. Londres: Sage Publications, 1997.

et al. Commitment in a change world of work. Canadian Psychology. 39, p.83-93, 1998.

MILLS, D. Q et al. Managing human assets. In: SEMINÁRIO QUINN MILLS DE HAVARD. Recursos Humanos: diferencial para inovar e competir. São Paulo, AMANA, 1987. 
MINTZBERG, H. The fall and rise of strategic planning. Havard Business Review. EUA, p. 1014, jan/feb, 1994.

; O processo da estratégia. In: MINTZBERG, H.; QUINN, J. B. 3. ed. Porto Alegre: Bookman, 2001

MISHRA, K. E. Internal communication: bulding trust, commitment and a positive reputation through relationship management with employes. Carolina do Norte, 2007. 190 p. Tese (Doutorado em Psicologia). Escola de jornalismo e comunicação Social da Universidade da Carolina do Norte.

MORAES, L. F. R et al. Comprometimento Organizacional: uma contribuição ao Constructo. In: XXII ENCONTRO ANUAL DA ASSOCIAÇÃO DOS PROGRAMAS DE PÓS-GRADUAÇÃO EM ADMINISTRAÇÃO - ENANPAD, 22., 1998, Foz do Iguaçu. Anais... Foz do Iguaçu/ PR: ANPAD, 1998.

; KILIMNIK, Z. M. Comprometimento organizacional, qualidade de vida e stress no trabalho: uma abordagem de diagnóstico comparativo. Revista Brasileira de Administração Contemporânea. São Paulo, v. 1, n. 9, set/1995, p. 169-188, 1995.

MOWDAY, R. T. Refletions on the study and relevance of organizational commitment. Human Resource Management Review, v. 11, n. 3, 387-401, 1998.

- Reflections on the Study and Relevance of Organizational Commitment. Human Resource Management Review. Vol. 8, Issue 4, Winter, 1998.

et al. The measurement of organizational commitment. Journal of Vocational Psychology, 14, 224-447, 1979.

et al. Employee-organization linkages - the psychology of commitment, absenteism and turnover. New York: Academic Press, 1982.

et al. The measurement of organizational commitment. Journal of Vocational Behavior. $\overline{14,224-247,1979 .}$

MOREIRA, D. A. O método fenomenológico na pesquisa. São Paulo: Pioneira Thomson, 2002.

MURIEL, M.; ROTA, G. Comunicación institucional: enfoque social de relaciones publicas. Quito: CIESPAL, 1980.

NASSAR, P. Comunicação estratégica: um conceito em evolução. In: NASSAR Paulo (org.). Comunicação interna: a força das empresas. São Paulo: ABERJE, 2005. v. 2.

A administração da Comunicação empresarial. Disponível em: http://www.aberje.com.br/clipping/clipping.htm. Acesso em 15 de dezembro de 2007. 
NONAKA, I. A empresa criadora do conhecimento. In: Gestão do conhecimento. Havard business review. Tradução de Afonso Celso da Cunha Serra. Rio de Janeiro: Campus.

OLIVEIRA, I. L Dimensão estratégica da comunicação no contexto organizacional contemporâneo: um paradigma de interação comunicacional dialógica. Rio de Janeiro, 2002. 176 p. Tese (Doutorado em Comunicação). Escola de Comunicação da Universidade Federal do Rio de Janeiro.

OLIVEIRA, D. P. R. Planejamento estratégico: conceitos, metodologia e práticas. 20.ed. São Paulo: Atlas, 2004.

OLIVEIRA, I. L.; PAULA M. A. Componentes da comunicação estratégica: uma reflexão sobre a articulação entre os aspectos teórico-conceituais e práticos. In: XXIX CONGRESSO BRASILEIRO DE CIÊNCIAS DA COMUNICAÇÃO, 29., 2006, Brasília, DF, UNB. Anais. Brasília, DF: INTERCOM, 2006.

O'REILLY III, C.; CHATMAN, J. Organizational commitment and psychological attachment: the effects of compliance, identification and internalization on prosocial behavior. Journal of Applied Psychological. 71 (3), 492-99, 1986.

; PFEFFER, J. Talentos ocultos: como as melhores empresas obtêm resultados extraordinários com pessoa comuns. Rio de Janeiro: Campus, 2001.

PARASURAMAN, A. Marketing research. Addison: Wesley Publishing Company, 1991.

PASTORE, J. Flexibilização dos mercados de trabalho e contratação coletiva. São Paulo: LTR, 1995.

. Mediação trabalhista. Jornal Folha de São Paulo. São Paulo, 1995.

PEREIRA, C. A. M.; HERSCHMANN, M. Comunicação e novas estratégias comunicacionais na era da informação e do conhecimento. Comunicação \& Sociedade. São Bernardo do Campo, 2. sem., 2000.

PEREIRA, E. L. I. Comunicação Interna Excelente: perfil e papel do gestor do processo comunicativo nas organizações. São Paulo, 2003. 104 p. Dissertação (Mestrado em Comunicação - ciências da comunicação). Escola de Comunicações e Artes, Universidade de São Paulo.

PFEFFER, J. Vantagem competitiva através de pessoas. São Paulo: Makron Books, 1994.

PIÑUEL RAIGADA. J. L. Teoria de la cominucación y gestión de las organizaciones. Madrid: Editorial Síntesis, 1997.

PIRES, J. C. L.; PICCININI, M. S. Aspectos tecnológicos dos serviços de telecomunicações. Rio de Janeiro: BNDES, dez. 1997, Ensaios BNDES, 5. 
PIRES, J. C. L. Políticas regulatórias no setor de telecomunicações: a experiência internacional e o caso brasileiro. Textos para discussão. Rio de Janeiro: BNDES, 1999.

POSTMES, $\mathrm{T}$ et al. Communication and commitment in organizations: a social identity approach. Group Processes \& Intergroup Relations. V. 4, n. 3, 2001, 227-246.

PUTNAM, L et al. Metáforas da comunicação e da organização. In: CLEGG, S. R.; HARDY, C.; NORD, W. R. (Org.) Handbook de estudos organizacionais: Ação e análise organizacionais. São Paulo: Atlas, 2004, v.3.

REDFILED, C. E. Comunicações administrativas. Rio de Janeiro: Zahar Editores, 1978.

- Comunicações administrativas. Trad. De Sylla Magalhães Chaves. 4. ed. Rio de Janeiro: FGV, 1980.

REGO, A.; SOUTO, S. Comprometimento organizacional em organizações autentizóticas: um estudo luso-brasileiro. Revista de Administração de Organizações, São Paulo, v.44, n.3, p. 3043, jul/set. 2004.

A percepção da justiça como antecedentes do comprometimento organizacional: um estudo luso-brasileiro. Revista de Administração Contemporânea, São Paulo, v.8, n.1, 151177jan/mar. 2004.

REGO, F. G. R. T. Comunicação organizacional/comunicação institucional. Conceitos, estratégias, sistemas, estrutura, planejamento e técnicas. $5^{\text {a }}$ ed. São Paulo: Summus Editorial. 1986. 2002.

. Tratado de comunicação organizacional e política. São Paulo: Thompson Learning,

REIS, A. H. M. A. M. Pesquisa Qualitativa em Marketing: Uma visão crítica a respeito da utilização desta metodologia no Brasil, a partir de testemunho de clientes e usuários de São Paulo. São Paulo, 1994. 151 p. Dissertação (Mestrado em Administração) - Dissertação (Mestrado em Administração) - Faculdade de Economia, Administração e Contabilidade, Universidade de São Paulo.

REIS, M. C. comunicação e mudança organizacional: uma interlocução instrumental e constitutiva. In: Revista Brasileira de Comunicação Organizacional e Relações Públicas ORGANICOM. Universidade de São Paulo, Escola de Comunicação e Artes, n. 1, ago, 2004.

RESTREPO, J. M. ÂNGULO, J. R. Intervenir em la organización. Santefé de Bogotá: Significantes de Papel. Ediciones, Serie: Comunicación Organizacional, 1995.

REVISTA DE COMUNICACAO EMPRESARIAL, Ano 12, no 45, 4 ${ }^{\mathrm{o}}$ trimestre de 2002. Encarte: pesquisa ABERJE, 2002 - Comunicação interna. 
RICCO, M. F. F. Comprometimento organizacional em condições adversas: o caso dos pesquisadores do Centro Técnico Aeroespacial. Dissertação de Mestrado. São Paulo, 1998. 89 p. Dissertação (Mestrado em Administração) Faculdade de Economia, Administração e Contabilidade, Universidade de São Paulo.

RICHARDSON, R. J et al. Pesquisa social: métodos e técnicas. São Paulo: Atlas, 1999.

RIEL, C. B. M. Principles of corporate communication. Hemel Hempstead, Prentice-Hall, 1995.

RITA, L. P. S. Serviços no setor de telefonia móvel: uma análise sob a dimensão da competitividade, 2004. 178 p. Tese (Doutorado em Administração) - Faculdade de Economia, Administração e Contabilidade, Universidade de São Paulo.

ROBBINS, S. P. Comportamento organizacional. 9. ed. São Paulo: Prentice-Hall, 2002.

RODRIGUEZ DE SAN MIGUEL, H. A. Hacia una definición de la comunición organizacional. In: COLLADO, Carlos F. La comunición em las organizaciones. 2. ed. México: Trillas, 1996.

RUAS, Roberto; ANTUNES, Elaine. Estruturação, programas de qualidade e práticas de benefícios e incentivos: a questão do "comprometimento". In: CARLEIAL, Liana; VALLE, Rogério (Org.). Reestruturação produtiva e mercado de trabalho no Brasil. São Paulo: Hucitec-Abet, 1997.

SAKYI, K. E. Communication challenges in implementing health sector decentralisation at district level in Ghana: a study of health workforce and stakeholder opinions from three district health administrations. Leadership in Health Services. V. 23, n. 2, 2010, 156-171.

SAMGNANAKKAN, S. Mediating role of organizational commitment on RH practices and turnover intention among ICT professionals. Journal of Management Research, vol. 10, n. 1, April 2010, p. 39-61

SCHEIBLE, A. C. F.; BASTOS, A. V. Práticas de gestão do comprometimento em projeto de melhoria do processo de software. Paraná: In: Revista de Práticas Administrativas - RPA, Ano 2, v. 2, n. 4. Maringá: UNICORPORE, 2006.

SELLTIZ, C et al. Métodos de pesquisa nas relações Sociais. São Paulo: EPU, 2005.

SCHEIN, E. H. Guia de sobrevivência da cultura corporativa. Rio de Janeiro: José Olympio, 2001.

- Organizational culture and leadership. 2nd ed. San Francisco, Jossey Bass Inc, Publishers: 1992.

SHANNON, C.; WEAVER, W. The mathematical theory of communication. University of Illinois Press, Urbana, 1949.

SOUZA, J. P. Planificando comunicação em relações públicas. Florianópolis: Secco, 2004. 
SROUR, R. H. Poder, cultura e ética nas organizações. São Paulo: Campus, 1998.

STEVENSON, W. J. Estatística aplicada à administração. Trad. Alfredo Alves de Farias. São Paulo: Harper e Row do Brasil, 1981.

TAVARES, R. S. A. A importância da comunicação interna para o desenvolvimento do comprometimento organizacional: estudo de caso em empresa Brasileira. São Paulo, 2005a. 193 p. Dissertação (Mestrado em Administração) - Faculdade de Economia, Administração e Contabilidade, Universidade de São Paulo.

; LIMONGI-FRANÇA, A. C. Comprometimento organizacional e comunicação interna: um estudo desenvolvido na empresa de telecomunicação em Cabo Verde. In: XXXIII ENCONTRO NACIONAL DE PÓS-GRADUAÇÃO EM ADMINISTRAÇÃO, 33, 2009, São Paulo/SP. Anais. São Paulo, SP; ENANPAD, 2009.

; LIMONGI-FRANÇA, A. C. A importância do planejamento da comunicação no processo de uma comunicação interna eficaz: um estudo de caso. In: XXVIII CONGRESSO BRASILEIRO DE CIÊNCIAS DA COMUNICAÇÃO, 28, 2005, Rio de Janeiro, Universidade Estadual do Rio de Janeiro. Setembro. Anais. Rio de Janeiro, RJ: INTERCOM, 2005.

; LIMONGI-FRANÇA, A. C. A relevância da Comunicação Interna Planejada Para o Desenvolvimento do Comprometimento Organizacional. RACEF: Revista de Administração, Contabilidade e Economia da FUNDACE, set./2010

TENÓRIO, F. G. Flexiblização organizacional: mito ou realidade. Rio de Janeiro: Editora FGV, 2000 .

THAYER, L. O. Princípios de comunicação na administração: comunicação e sistemas de comunicação na organização da administração e relações internas. São Paulo: Atlas, 1972

. Comunicação: fundamentos e sistemas na organização, na administração, nas relações interpessoais. São Paulo: Atlas, 1976.

TOMLINSON, G. Building a culture of high employee engagement. Strategic HR Review. Vol. 9 , n. 3, 2010, p. 25-31.

ULRICH, D. Os campeões de recursos humanos: inovando para obter os melhores resultados. Tradução de Cid Knipel. São Paulo: Futura, 2003a.

. Recursos Humanos estratégicos: novas perspectivas para os profissionais de RH. Trad. de Bazán Tecnologia e Lingüística. São Paulo: Futura, 2003b.

URIBE, P. A. M.; ZULUAGA, U. H. S. Comunicatión empresarial: Una mirada corporativa. Medellin: Colombia: Colección Hermes, 2003. 
VARONA, F. Conceptualization and Management of Communication Satisfaction and Organizational Commitment in Three Guatemalan Organizations. American Communication Journal, v.5, n.3, Spring, 2002.

VENTURA, C. A. A. As agências reguladoras e seu papel na reestruturação do setor de telecomunicações: um estudo comparativo da Agência Nacional de Telecomunicações (ANATEL) - Brasil e da Federal Communications Commission (FCC) - EUA. São Paulo, 2004. 239 p. Tese (Tese de Doutorado) - Faculdade de Economia, Administração e Contabilidade, Universidade de São Paulo.

VERGARA, S. C. Gestão de pessoas. 2. ed. São Paulo: Atlas, 2000.

VIEIRA, M. M. F. Por uma boa pesquisa (qualitativa). In: VIEIRA, Marcelo F.; ZOUAIN, D. M. (Org.). Pesquisa qualitativa em Administração. Rio de Janeiro: FGV, 2002.

WALTON, R. E. Do controle ao comprometimento no local de trabalho. In: VROOM, V. (Org.). Gestão de pessoas, não de pessoal. Rio de Janeiro: Campus, 1997.

WATKINS, A. M. Communication and Organizational Commitment: Perceived Organizational Support as a Mediating Factor. Communication Quarterly, 40 (4), 357-367, 1992.

WIENER, Y. Commitment in organizations: a normative view. Academy of Management Review. 7 (3), 418-428, 1982.

YIN, R. K. Estudo de caso: Planejamento e métodos. Trad. Daniel Grassi. 3. ed. Porto Alegre: Bookman, 2005.

YOUNG, M. POST, J. E. Managing to communicate, communicating to manage. How leading companies communicate with employees. Organizational Dynamics, 1995. 


\section{APÊNDICES}




\section{Apêndice A - Questionário de pesquisa}

Prezado (a) Senhor (a),

Solicitamos a sua colaboração no levantamento de dados que estamos a realizar sobre comunicação interna e comprometimento organizacional dos funcionários, com vista à elaboração da tese de doutorado de Rosalina Tavares, que será apresentada à Faculdade de Administração da Universidade de São Paulo (FEA-USP).

O questionário está dividido em duas partes: A primeira é constituída por um conjunto de afirmativas que busca avaliar a sua percepção a respeito de cada frase. Ao responder o questionário, manifeste a sua concordância ou discordância com cada afirmativa, colocando um " $\mathrm{X}$ " na opção correspondente à sua opinião.

A segunda parte contém questões para levantamento de dados de caracterização pessoal, que nos permitirão formar o perfil dos entrevistados.

Gostaríamos de ressaltar o caráter estritamente acadêmico desta pesquisa, garantindo-lhe o sigilo absoluto das suas respostas que serão tratadas de forma consolidada sem distinção individual. Apenas a pesquisadora terá acesso aos dados, garantindo assim a confidencialidade das respostas. Como pode verificar, este questionário não pede, em nenhum momento a identificação do entrevistado pelo seu nome, justamente para lhe dar total liberdade de resposta.

Cordialmente,

Rosalina Semedo de Andrade Tavares (pesquisadora)

IMPORTANTE: Responda considerando, sempre, os últimos seis meses da organização!

\section{Questionário de Pesquisa}

\begin{tabular}{|c|c|c|}
\hline \multicolumn{3}{|c|}{$\begin{array}{l}\text { 1. Quais são os principais meios utilizados para a comunicação com os empregados? (Pode marcar MAIS } \\
\text { de UMA opção). }\end{array}$} \\
\hline a. ( ) Vídeos & e. ( ) Correio eletrônico & i. ( ) Videoconferência \\
\hline b. ( ) Intranet & f. ( ) Boletins & j. ( ) Manuais \\
\hline c. ( ) Rádio-organização & g. ( ) Jornais & k. ( ) Relatórios de atividade \\
\hline d. ( ) Memorando & h. ( ) Revistas & 1. ( ) Outro. Qual? \\
\hline \multicolumn{3}{|c|}{ 2. Os programas de comunicação interna são desenvolvidos pelo: } \\
\hline \multicolumn{3}{|c|}{$\begin{array}{ll}\text { a. ( ) } & \text { Departamento de Comunicação. } \\
\text { b. ( ) } & \text { Departamento de Recursos Humanos. } \\
\text { c. ( ) } & \text { Departamento de Comunicação em parceria com o de Recursos Humanos. } \\
\text { d. ( ) } & \text { Outro. Qual? }\end{array}$} \\
\hline \multicolumn{3}{|c|}{$\begin{array}{l}\text { 3. Os canais de comunicação da organização, que traduzem diretrizes, inovações, normas, valores e } \\
\text { manifestações nos mais variados assuntos, são: (Pode marcar MAIS de UMA opção) }\end{array}$} \\
\hline a. ( ) Cartas circulares & e. ( ) Intranet & i. ( ) Mensagens no relatório de atividade \\
\hline b. ( ) Quadro de avisos & f. ( ) Reuniões & j. ( ) Manuais \\
\hline $\begin{array}{l}\text { c. ( ) E-mail - correio } \\
\text { eletrônico }\end{array}$ & g. ( ) Encontros especiais & k. ( ) Outro. Qual? \\
\hline d. ( ) Memorando & h. ( ) Revistas & \\
\hline \multicolumn{3}{|c|}{ 4. Existe, dentre as formas como as comunicações fluem na empresa uma que prevaleça sobre as outras? } \\
\hline \multicolumn{3}{|c|}{ 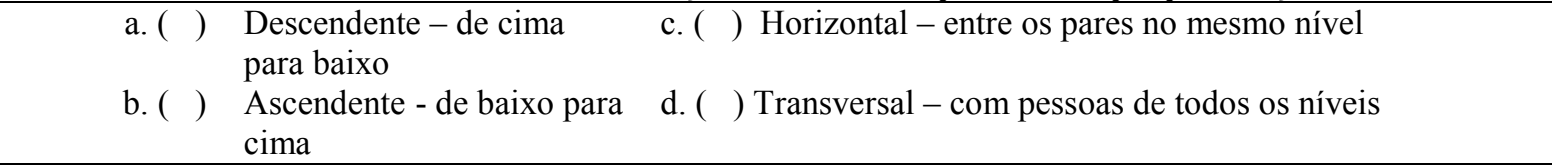 } \\
\hline
\end{tabular}


Marque com um "X" a opção que melhor expressa a sua opinião (Escolha APENAS UMA alternativa).

\begin{tabular}{|c|c|c|c|c|c|}
\hline $\mathbf{N}^{\mathbf{0}}$ & Questão & $\begin{array}{c}\text { Concordo } \\
\text { Totalmente }\end{array}$ & Concordo & Discordo & $\begin{array}{l}\text { Discordo } \\
\text { Totalmente }\end{array}$ \\
\hline 05 & $\begin{array}{l}\text { A organização permite a comunicação entre ela e os } \\
\text { funcionários. }\end{array}$ & & & & \\
\hline 06 & $\begin{array}{l}\text { Eu concordo com as práticas adotadas pela minha } \\
\text { organização. }\end{array}$ & & & & \\
\hline 07 & $\begin{array}{l}\text { Nesta organização a comunicação de baixo para cima é } \\
\text { prioritária. }\end{array}$ & & & & \\
\hline 08 & Eu acredito nos valores e objetivos desta organização. & & & & \\
\hline 09 & $\begin{array}{l}\text { Nesta organização a comunicação é vista como importante } \\
\text { para o bom funcionamento do negócio. }\end{array}$ & & & & \\
\hline 10 & $\begin{array}{l}\text { Eu sempre me esforço para que a organização atinja seus } \\
\text { objetivos. }\end{array}$ & & & & \\
\hline 11 & $\begin{array}{l}\text { Existem canais que permitem comunicação com os } \\
\text { funcionários de todos os níveis. }\end{array}$ & & & & \\
\hline 12 & Eu gostaria de trabalhar nesta organização por muitos anos. & & & & \\
\hline 13 & $\begin{array}{l}\text { Eu sinto que sou incentivado (a) a conhecer todo o negócio } \\
\text { desta organização. }\end{array}$ & & & & \\
\hline 14 & Esta organização valoriza os bons princípios. & & & & \\
\hline 15 & $\begin{array}{l}\text { Eu não recebo informações de outros setores/ departamentos } \\
\text { da organização. }\end{array}$ & & & & \\
\hline 16 & $\begin{array}{l}\text { Eu gosto de pertencer a esta organização porque sou escutado } \\
\text { e sempre recebo feedback. }\end{array}$ & & & & \\
\hline 17 & Eu tenho oportunidades de participar das decisões. & & & & \\
\hline 18 & $\begin{array}{l}\text { Eu tenho, nesta organização, oportunidades de comunicar } \\
\text { com a alta direção. }\end{array}$ & & & & \\
\hline 19 & $\begin{array}{l}\text { Conversando com os amigos, eu sempre me refiro a minha } \\
\text { organização como uma grande instituição para a qual eu me } \\
\text { orgulho em trabalhar. }\end{array}$ & & & & \\
\hline 20 & $\begin{array}{l}\text { Nunca tenho clareza sobre quais são as minhas } \\
\text { responsabilidades no trabalho. }\end{array}$ & & & & \\
\hline 21 & $\begin{array}{l}\text { Eu sou muito envolvido (a) pessoalmente com o meu trabalho } \\
\text { atual porque a organização me comunica tudo a respeito do } \\
\text { seu negócio. }\end{array}$ & & & & \\
\hline 22 & $\begin{array}{l}\text { Nesta organização existem mecanismos que me permitem } \\
\text { falar com meus superiores diretos, indiretos e colegas. }\end{array}$ & & & & \\
\hline 23 & $\begin{array}{l}\text { Para manter-me na empresa, procuro fazer sempre o que é } \\
\text { esperado de mim. }\end{array}$ & & & & \\
\hline 24 & $\begin{array}{l}\text { Sempre tenho oportunidade de participar de decisões que } \\
\text { afetam o meu trabalho. }\end{array}$ & & & & \\
\hline 25 & $\begin{array}{l}\text { Procuro não transgredir as regras aqui, pois assim sempre } \\
\text { manterei meu emprego. }\end{array}$ & & & & \\
\hline 26 & $\begin{array}{l}\text { As minhas responsabilidades são comunicadas pela minha } \\
\text { chefia imediata. }\end{array}$ & & & & \\
\hline 27 & É importante realizar, naturalmente, o trabalho solicitado. & & & & \\
\hline 28 & $\begin{array}{l}\text { Freqüentemente sou informado (a) sobre o que se passa } \\
\text { dentro da organização. }\end{array}$ & & & & \\
\hline
\end{tabular}




\begin{tabular}{|c|c|c|c|c|c|}
\hline $\mathbf{N}^{\mathbf{o}}$ & Questão & $\begin{array}{l}\text { Concordo } \\
\text { Totalmente }\end{array}$ & Concordo & Discordo & $\begin{array}{l}\text { Discordo } \\
\text { Totalmente }\end{array}$ \\
\hline 29 & $\begin{array}{l}\text { Se todos fizessem sempre o necessário não haveria demissões } \\
\text { na organização. }\end{array}$ & & & & \\
\hline 30 & $\begin{array}{l}\text { Eu tenho oportunidades de participar de reuniões e/ou } \\
\text { encontros especiais, nos quais exponho a minha opinião. }\end{array}$ & & & & \\
\hline 31 & $\begin{array}{l}\text { Não gostaria de deixar minha empresa, já que investi bastante } \\
\text { da minha vida aqui. }\end{array}$ & & & & \\
\hline 32 & $\begin{array}{l}\text { A área de comunicação, nesta organização, só funciona para } \\
\text { resolver problemas em momentos de crise. }\end{array}$ & & & & \\
\hline 33 & $\begin{array}{l}\text { Esta organização me dá benefícios que dificilmente } \\
\text { encontraria em outro local. }\end{array}$ & & & & \\
\hline 34 & $\begin{array}{l}\text { Mesmo em questões pequenas temos que buscar alguém de } \\
\text { mais alto nível para a decisão final. }\end{array}$ & & & & \\
\hline 35 & Empregado tem a obrigação de sempre cumprir suas tarefas. & & & & \\
\hline 36 & $\begin{array}{l}\text { As estratégias de comunicação, nesta organização, são } \\
\text { traçadas a partir da visão, missão, valores da organização, } \\
\text { visando o alcance de resultados. }\end{array}$ & & & & \\
\hline 37 & $\begin{array}{l}\text { Uma das coisas mais importantes na organização é cumprir } \\
\text { suas normas e regulamentos. }\end{array}$ & & & & \\
\hline 38 & $\begin{array}{l}\text { A área de comunicação, nesta organização, é planejada, } \\
\text { pensada e administrada estrategicamente. }\end{array}$ & & & & \\
\hline 39 & $\begin{array}{l}\text { Sinto-me comprometido com a Visão, Missão, Objetivos e } \\
\text { Estratégias da empresa. }\end{array}$ & & & & \\
\hline 40 & $\begin{array}{l}\text { O processo de comunicação nesta organização promove a } \\
\text { integração entre os diferentes setores/ departamentos. }\end{array}$ & & & & \\
\hline 41 & $\begin{array}{l}\text { Todo empregado deve buscar atingir os objetivos da } \\
\text { organização. }\end{array}$ & & & & \\
\hline 42 & $\begin{array}{l}\text { A comunicação, nesta organização, ocupa um espaço } \\
\text { estratégico na estrutura organizacional. }\end{array}$ & & & & \\
\hline 43 & $\begin{array}{l}\text { O bom empregado deve dedicar-se de corpo e alma a sua } \\
\text { organização. }\end{array}$ & & & & \\
\hline 44 & $\begin{array}{l}\text { Nesta organização, os funcionários são convidados a } \\
\text { participar das decisões. }\end{array}$ & & & & \\
\hline 45 & Sinto-me culpado se não consigo realizar bem minhas tarefas. & & & & \\
\hline 46 & Identifico-me com a filosofia desta organização. & & & & \\
\hline 47 & $\begin{array}{l}\text { Eu tenho obrigação em desempenhar bem a minha função na } \\
\text { organização. }\end{array}$ & & & & \\
\hline 48 & $\begin{array}{l}\text { Eu recebo feedback dos meus superiores sobre o desempenho } \\
\text { das minhas funções. }\end{array}$ & & & & \\
\hline 49 & $\begin{array}{l}\text { Sinto-me obrigado (a) a fazer coisas cada vez melhores aqui } \\
\text { na organização. }\end{array}$ & & & & \\
\hline 50 & $\begin{array}{l}\text { O processo de comunicação interna na empresa é eficiente, } \\
\text { eficaz e satisfatório. }\end{array}$ & & & & \\
\hline
\end{tabular}




\begin{tabular}{|l|l|l|l|l|}
\hline \multicolumn{1}{|c|}{ Questão } & \multicolumn{1}{|c|}{$\begin{array}{c}\text { Q } \\
\text { Concordo } \\
\text { Totalmente }\end{array}$} & Concordo & Discordo & $\begin{array}{c}\text { Discordo } \\
\text { Totalmente }\end{array}$ \\
\hline 51 & $\begin{array}{l}\text { Eu não sinto nenhuma obrigação em permanecer nesta } \\
\text { organização. }\end{array}$ & & \\
\hline 52 & $\begin{array}{l}\text { Eu conheço a Visão, Missão, Objetivos, Estratégias, Políticas } \\
\text { e Metas da empresa. } \\
\text { O bom desempenho na organização é uma decorrência de } \\
\text { sempre respeitar suas regras. }\end{array}$ & & & \\
\hline
\end{tabular}

\section{Perfil do Entrevistado}

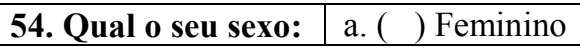

55. Qual a sua faixa etária? a. ( ) 18 a 25

b. ( ) Masculino

b. ( ) 26 a 35

c. ( ) 36 a 45

d. ( ) 46 a 60

a. ( ) mais de 60

56. Há quanto tempo você trabalha nesta organização? a. ( ) menos de 2 anos

c. ( ) entre 6 a 8 anos d. ( ) entre 9 a 11 anos

a. ( ) mais de 12 anos

57. Indique seu Nível de escolaridade

\begin{tabular}{|l|l|}
\hline & Ensino Básico integrado/ primário \\
\hline & Ensino Secundário \\
\hline & Curso Médio \\
\hline & Curso Superior
\end{tabular}

58. Qual a sua formação Ensino Básico integrado/ primário

\begin{tabular}{|l|}
\hline a. ( ) Incompleto \\
\hline a. ( ) Incompleto \\
c. ( ) Incompleto \\
\hline e. ( ) Incompleto
\end{tabular}

b. ( ) entre 2 a 5 anos

59. Especialização (Pós-graduação)

a. ( ) MBA

b. ( ) Mestrado

c. ( ) Doutorado

d. ( ) Outro: Indique

60. Qual o seu cargo atual?

61. Qual o seu estado civil?

a. ( ) Solteiro

b. ( ) Casado

c. ( ) Viúvo

d. ( ) Outro:

62. Tem filhos?

a. ( ) Sim Quantos?

b. ( ) Não

Rosalina Semedo de Andrade Tavares (pesquisadora)

E-mail: rosandrade@usp.br

Telefone: +55 11-81486670
Profa Profa. Dra. Ana Cristina Limong- França (orientadora)

E-mail: E-mail: climongi@usp.br

TelefonTelefone : + 5511 - 30915908

\section{Muito obrigada pela sua colaboração!}




\section{Apêndice B - Roteiro de pesquisa: Entrevista}

\section{PERFIL DA EMPRESA - BREVE HISTÓRICO}

1. Há quanto tempo foi fundada a empresa e por quem?

2. Quais são os produtos/ serviços básicos oferecidos pela empresa?

3. Onde fica a empresa? A empresa tem filial? Se sim, quantas e onde se localizam?

4. Quantos empregados possui a empresa (esta filial, se for o caso)? E o grupo todo?

5. Qual o faturamento anual bruto/ líquido?

6. Qual a participação de mercado?

7. Quais os principais mercados e clientes?

8. Como esta empresa definiria seu negócio? A empresa trabalha com os conceitos de visão, missão, objetivos e metas? Se sim, com que finalidade?

9. Qual a estrutura organizacional/ organograma da empresa?

\section{PROCESSO DE SOCIALIZAÇÃO}

1. Quando um novo integrante entra na empresa existe um roteiro para apresentá-lo a todos? Isso é feito em grupos ou individualmente?

2. Existe um treinamento específico para quem está iniciando a função? Como o novato aprende sua nova atividade? (sozinho, com supervisor, treinamento formal, etc?).

\section{ASPECTOS SOBRE COMUNICAÇÃO}

\section{a) Sistema de comunicação:}

1. Como se processam as redes formal e informal?

2. Quais as características e como se processam os fluxos de informação ascendente, descendente, horizontal, transversal e circular?

3. Existe estrutura departamental ou setorial da comunicação? (Qual o setor ou departamento responsável pela comunicação da organização? Esse setor está subordinado à presidência, diretoria tal ou outra área)?

4. Existe divisão ou subárea: relações públicas, assessoria de imprensa e comunicação interna?

5. Quais os canais de comunicação da organização que traduzem diretrizes, inovações, normas e manifestações nos mais variados assuntos?

6. Qual a missão da área de comunicação (clareza e entendimento do enunciado de missão e visão da organização)?

7. Existe um percentual específico no orçamento da empresa destinado às atividades de comunicação? 
8. A organização propicia oportunidades para uma comunicação participativa, priorizando o fluxo ascendente?

9. Freqüentemente se realizam reuniões e ou encontros especiais para ouvir o que o empregado tem a dizer?

10. Existe uma preocupação da empresa em fazer como que todos os funcionários conheçam o negócio da empresa como um todo? Como se processa?

\section{b) Planejamento da Comunicação:}

11. Existe um planejamento de comunicação organizacional? Existe alinhamento entre planejamento de comunicação e planejamento estratégico da empresa?

12. A área de comunicação ocupa espaço estratégico na estrutura organizacional?

13. Existe capacitação do executivo principal responsável pela comunicação e da equipe que conduz o processo?

\section{GESTÃO DE PESSOAS}

14. Fala um pouco como é a política de Gestão de Pessoas na organização (contratação; treinamento; carreira; remuneração e uso de incentivos individuais e grupais).

15. Como é a estrutura organizacional (níveis hierárquicos; organização do trabalho e sistema de controle).

16. Como são as relações de trabalho (política de emprego; nível de formação requerida; relações empregado-empregador; participação dos empregados nas decisões).

17. Existe um comprometimento dos funcionários com a empresa e eles se identificam com os objetivos organizacionais? Por quê?

18. Os empregados são considerados parceiros no trabalho e a empresa investe neles para conseguir melhores resultados empresariais?

19. Você dá, regularmente, feedback aos seus subordinados sobre o desempenho das suas tarefas?

20. Você conhece a Missão, Visão, Política e Metas da empresa? Sente-se comprometido (a) com elas?

21. Como se explica o engajamento das pessoas aos objetivos e metas da empresa?

22. As pessoas, ao desempenharem suas funções, sabem para quê se destina o que estão fazendo?

23. Que papel desempenha a comunicação na gestão de pessoas?

24. Você é comprometido com os objetivos organizacionais? Por quê?

25. Você acha que os funcionários da empresa são comprometidos com a organização? Por quê? 